\title{
Jauno \\ vēsturnieku \\ zinātniskie \\ lasījumi
}

\section{$3 / 2017$}

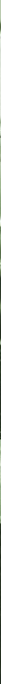




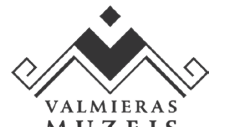

MUZEJS
LATVIJAS UNIVERSITĀTE

LATVIJAS VĒstures LET( NIKA INSTITŪTS 

VALMIERAS PILSĒTAS PAŠVALDĪBAS VALMIERAS MUZEJS LATVIJAS UNIVERSITĀTES LATVIJAS VËSTURES INSTITÜTS

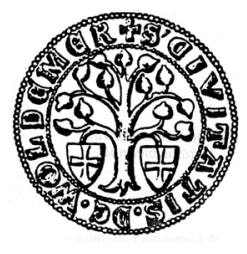

\section{Jauno vēsturnieku zinātniskie lasījumi III}

Starpdisciplināri pētījumi Latvijas vēsturē

\section{The Scholarly Readings of Young Historians III}


Jauno vēsturnieku zinātniskie lasījumi III. Starpdisciplināri pētījumi Latvijas vēsturē $=$ The Scholarly Readings of Young Historians III. Sast. Ilze Boldāne-Zel̦enkova un Alberts Rokpelnis. - Rīga: LU Akadēmiskais apgāds, 2018. 136 lpp.

Izdevumā "Jauno vēsturnieku zinātniskie lasījumi III" publicēti deviņi raksti, kuru pamatā ir ziņojumu materiāli, kas nolasīti 2017. gada 20. oktobrī Valmierā, Valmieras muzeja un Latvijas Universitātes Latvijas vēstures institūta rīkotajā konferencē "Jauno vēsturnieku zinātniskie lasījumi".

Krājumu izdod Valmieras pilsētas pašvaldības Valmieras muzejs sadarbībā ar Latvijas Universitātes Latvijas vēstures institūtu.

Visi raksti ir anonīmi recenzēti. Recenzenti: nozares speciālisti no Latvijas Universitātes Latvijas vēstures institūta, Vēstures un filozofijas fakultātes, Filozofijas un socioloğijas institūta.

Krājuma sastādītāji: Ilze Boldāne-Zeḷenkova un Alberts Rokpelnis

Zinātniskā redkolēgija: Dr. hist. Viktorija Bebre (atbildīgā redaktore), Dr. hist. Ilze Boldāne-Zelenkova, Dr. hist. Rūdolfs Brūzis, Dr. hist. Ilgvars Butulis, Dr. hist. Anita Čerpinska, Dr. hist. Eva Eihmane, Dr. hist. Edvīns Evarts, Dr. art. Jānis Kudiņš, Dr. hist. Tālis Pumpuriņš

Redaktores: Ruta Puriṇa (latviešu val.) un Eva Eihmane (angḷu val.) Maketētāja Andra Liepiṇa

Vāka dizains Baiba Lazdiṇa (LU Akadēmiskais apgāds)

(C) Latvijas Universitāte, 2018

(C) Rakstu autori, 2018

(C) Valmieras muzejs, 2018

(C) LU Latvijas vēstures institūts, 2018

DOI: https://doi.org/10.22364/jvzl.03

ISBN 978-9934-18-379-9 


\section{Saturs}

PRIEKŠVĀRDS ........................ 7

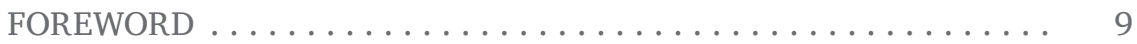

Jānis Šiliṇš

Lielais meklējumu gads: Vidzeme 1917. gada

politiskajos procesos . . . . . . . . . . . . . . . 11

The Year of The Great Quest: Vidzeme in the Political

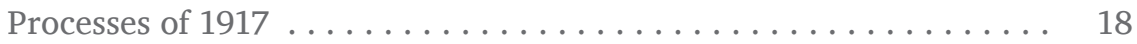

Viesturs Rasnacis

Vācijas loma Latvijas uzṇemšanā NATO (1991-2004) . . . . . . . . . 21

The Role of Germany in Latvia's Accession to NATO (1991-2004) . . . 30

Ginta Ieva Bikše

Dienests Neiejaukšanās komitejā Spānijas pilsoṇu kara lietās:

Latvijas pilsonu ziṇojumi $\ldots \ldots \ldots \ldots \ldots \ldots \ldots \ldots \ldots$

Reports by Latvian Citizens on Their Service in

the Non-Intervention Committee . . . . . . . . . . . . . . . . 40

\section{Kaspars Strods}

Holokausts Varakḷānu un tās apkārtnes iedzìvotāju komunikatīvajā atmin̄ā .................... 42

Jews in the Communicative Memory of the Inhabitants

of Varakḷāni and the Surrounding Area: the Holocaust . . . . . . . 52

\section{Agnija Lesničenoka}

Latvijas Mākslas akadēmijas akadēmiskās studentu

organizācijas (1923-1940): to loma sabiedrībā un

jauno mākslinieku profesionālajā izaugsmē

Academic Student Organisations of the Art Academy

of Latvia (1923-1940): Their Role in Society and in

the Professional Development of Young Artists 


\section{Mārtiņš Dātavs}

Latvijas dzīvnieku aizsardzības biedrības darbība (1935-1940) . . . . 67

The Activities of the Latvian Society for the Protection

of Animals (1935-1940) . . . . . . . . . . . . . . . . 79

\section{Liga Irbe}

Aizmirstie: Gideons Ernests fon Laudons un Toces pusmuiža.

Cilvēka un vietas atgriešanās stāsts . . . . . . . . . . . . 81

The Forgotten: Gideon Ernst fon Laudon and Toce Estate.

The Story of the Return of a Man and a Site . . . . . . . . . . . 96

\section{Liena Sakne}

Kurzeme un Gotlande: noturīgu kultūru kontaktu

raksturojums vēlajā dzelzs laikmetā . . . . . . . . . . . . 98

Courland and Gotland: Characterisation of the Long

Lasting Cultural Relations in the Late Iron Age . . . . . . . . . 109

\section{Vanda Visocka}

Liesinātāji vēlā bronzas laikmeta keramikas trauku

veidmasā: praktiskā un simboliskā nozīme . . . . . . . . . . . . 111

Temper in Clay Matrix during the Late

Bronze Age: Technical and Symbolical Aspects . . . . . . . . . . . 128

\section{Pielikums/Appendix}

Konferences "Jauno vēsturnieku zinātniskie

lasījumi III" programma . . . . . . . . . . . . . . . . . . . . . . . 131

Programme of Conference "The Scholarly Readings

of Young Historians III" 


\section{PRIEKŠVĀRDS}

Jauno vēsturnieku zinātnisko lasījumu konferences organizēšana un rakstu krājuma izdošana ir Valmieras muzeja un LU Latvijas vēstures institūta sekmīgas sadarbības rezultāts vairāku gadu garumā. "Jauno vēsturnieku zinātnisko lasījumu” trešajā krājumā apkopoti devin,i zinātniskie raksti, kas izstrādāti, paplašinot ziņojumus, kuri prezentēti konferencē, kas notika 2017. gada 20. oktobrī Valmieras muzejā.

Trešais krājums iznāk 2018. gadā tieši uz Latvijas valsts dibināšanas simtgadi. Tāpēc darbu ievada vadošā pētnieka, vēstures doktora Jāņa Šilin,a raksts "Lielais meklējumu gads: Vidzeme 1917. gada politiskajos procesos", kurā sniegts ieskats politiskajos procesos, kas risinājās gadu pirms neatkarīgas valsts pasludināšanas un izveidošanas.

Krājums komplektēts hronologiskā secībā, sākot ar jaunāko laiku vēstures tēmām un beidzot ar aizvēsturi, arheoloǵiskiem pētījumiem.

Aktuālu tēmu par Latvijas iestāšanos Ziemeḷatlantiskā līguma aliansē (NATO) atklāj jaunais vēsturnieks Viesturs Rasnacis, akcentējot Vācijas īpašo lomu un atbalstu Latvijas uzn,emšanai NATO (1991-2004).

Ginta Ieva Bikše pievērsusies maz zināmajam jautājumam par Latvijas attieksmi un nostāju Spānijas pilsoṇu karā. Cenšoties palikt neitrāla, Latvija iesaistījās Londonā izveidotajā Neiejaukšanās komitejas dienestā.

Kaspars Strods ir apkopojis un analizējis vietējo iedzīvotāju mutvārdu intervijās saglabājušās atmiņas par traǵiskajiem holokausta notikumiem Varakḷānos Otrā pasaules kara laikā.

Divi jaunie pētnieki pievērsušies biedrību darbībai Latvijā līdz 1940. gadam. Agnija Lesničenoka parāda, kāda bija Latvijas Mākslas akadēmijas trīs studentu organizāciju - "Dzintarzeme", "Veidola", "Zaḷā zeme" - loma sabiedrībā un jauno mākslinieku profesionālajā izaugsmē 1923.-1940. gadā. Savukārt Mārtiņš Dātavs raksturo Latvijas dzīvnieku aizsardzības biedrības darbību (1935-1940), kuras galvenais uzdevums bija izskaust cietsirdīgu izturēšanos pret dzīvniekiem, panākt dzīvnieku aizsardzības likumu pieņemšanu un uzturēt veterināro ambulanci un vienīgo Rīgas dzīvnieku patversmi. 
Interesants ir Līgas Irbes uzsāktais darbs. Viṇa pēta Toces pusmuižas un ar to saistīto dzimtu un pārstāvju vēsturi. Autore rakstā uzskatāmi ilustrē procesu, kā vēstures gaitā notiek personu un vietu aizmiršana, atmiṇu pārklāšanās un atgriešana sabiedrībā.

Rakstu krājumu noslēdz divi pētījumi arheologijā. Liena Sakne raksturo Kurzemes un Gotlandes salu iedzīvotāju noturīgos kultūru kontaktus vēlajā dzelzs laikmetā, pamatojoties uz esošajām un jaunatklātajām arheoloǵiskajām liecībām.

Starpdisciplināru pētījumu sniedz Vanda Visocka, analizējot vēlā bronzas laikmeta keramikas trauku veidmasas. Tas balstīts uz deviṇu Latvijas pilskalnu keramikas kolekciju makroskopiskām un petrogrāfiskām analīzēm.

Trešais "Jauno vēsturnieku zinātnisko lasījumu" rakstu krājums izstrādāts Valsts pētījumu programmas "Letonika" ietvaros, un tā izdošanu finansē Latvijas Universitātes Akadēmiskās attīstības projekts.

Dr. hist. Viktorija Bebre 


\section{FOREWORD}

The conference of scholarly readings by young historians, along with the publication of a volume of articles, represents the result of a fruitful collaboration over several years between Valmiera Museum and the Institute of Latvian History, University of Latvia. This third volume of "Scholarly Readings by Young Historians" brings together nine scholarly contributions, prepared by expanding papers presented at the conference held at Valmiera Museum on 20 October 2017.

This third volume is being published in 2018, precisely on the centenary of the founding of the Latvian state. Accordingly, the volume is introduced by an article written by Senior Researcher Jānis Siliņš, Doctor in History, entitled "The Year of the Great Quest: Vidzeme in the Political Processes of 1917", which provides an insight into the political processes occurring in the year before the declaration and establishment of the independent state.

The volume has been organised on a chronological basis, starting with themes from modern history and concluding with prehistory and archaeology.

The topical theme of Latvia's accession to the North Atlantic Treaty Organisation (NATO) is examined by the young historian Viesturs Rasnacis, who emphasises Germany's special role and support for Latvia's acceptance into NATO (1991-2004).

Ginta Ieva Bikše looks at the rather unexplored question of Latvia's attitude and position regarding the Spanish Civil War. Seeking to remain neutral, Latvia became involved in the work of the Non-Intervention Committee set up in London.

Kaspars Strods has brought together and analysed memories preserved in oral interviews with local residents concerning the tragic events of the Holocaust in Varakḷāni during the Second World War.

Two young researchers have addressed the activity of societies in Latvia up to 1940. Agnija Ruhocka looks at the role in society and in the professional development of young artists played by three student organisations at the Latvian Academy of Art - Dzintarzeme, Veidola and Zal̦ā zeme in the years 1923-1940. Mārtinš Dātavs traces the work of the Latvian 
Society for the Protection of Animals (1935-1940), the main tasks of which were: to eradicate cruelty towards animals, achieve the passing of a law on the protection of animals, and maintain a veterinary clinic and Riga's only animal shelter.

Lìga Irbe has addressed an interesting field of research: she is studying the history of Toce manor farm, and of the families and individuals connected with it. The author provides a clear illustration of the process whereby people and places are forgotten in the course of history, and whereby memories overlap and are returned to society.

The collection of papers concludes with two archaeological studies. Liena Sakne examines the abiding cultural contacts between the inhabitants of Kurzeme and Gotland during the Late Iron Age, applying previously known and newly-discovered archaeological evidence.

In an interdisciplinary study, Vanda Visocka analyses the fabrics of Late Bronze Age pottery vessels. The study is based on macroscopic and petrographic analysis of ceramic collections from nine hill-forts in Latvia.

The third volume of articles from the Scholarly Readings by Young Historians has been prepared in the frame of the National Research Programme Letonika, and has been published with funding from an Academic Development Project of the University of Latvia.

Dr. hist. Viktorija Bebre Translation by Valdis Bērziņš 


\title{
LIELAIS MEKLËJUMU GADS: VIDZEME 1917. GADA POLITISKAJOS PROCESOS
}

\author{
JĀNIS ŠILIN̦Š \\ Dr. hist., Latvijas Valsts vēstures arhīva vadošais pētnieks, Vidzemes Augstskolas \\ Sociālo, ekonomisko un humanitāro pētījumu institūta pētnieks \\ E-pasts: Janis.Silins@arhivi.gov.lu
}

\begin{abstract}
ANOTĀCIJA
Rakstā sniegts ieskats politiskajos procesos, kas risinājās Vidzemē (Vidzemes guberṇas latviešu daḷā) 1917. gadā. Pirmais pasaules karš sašḳēla Latvijas teritoriju divās daḷās, Kurzemei un Vidzemei nonākot Vācijas okupācijā. Latvijas neokupētajā daḷā (Latgalē un Zemgalē) pēc Februāra revolūcijas un cara Nikolaja II atteikšanās no troṇa risinājās dinamiski politiskie procesi. No vienas puses, sākot ar 1917. gada aprīli, iezīmējās straujš lieliniecisma popularitātes pieaugums ("Iieliniecisma vilnis"). No otras puses, latviešu demokrātiski pilsoniskajās un vēlāk arī sociāldemokrātiskajās aprindās attīstijjās Latvijas neatkarības ideja. Rakstā ir izvērtēti faktori, kas ietekmēja šos procesus, kā arī aplūkots politisko centru izvietojums Vidzemē 1917. gadā.
\end{abstract}

Atslēgas vārdi: Pirmais pasaules karš, Februāra revolūcija, lieliniecisma vilnis, neatkarības ideja, Latviešu pagaidu nacionālā padome.

\section{IEVADS}

1917. gads bija grandiozu politisko un sociālo transformāciju gads gan Krievijā, gan Vācijas armijas neokupētajā Latvijas daḷā (Vidzemē un Latgalē). Latvijai 1917. gads sākās ar nepamatotu cerību apvītajām un traǵiskajām Ziemassvētku kaujām 5. janvārī (pēc vecā stila 1916. gada 23. decembrī), pie varas Krievijā vēl atrodoties caram Nikolajam II, un noslēdzās ar lielinieku nākšanu pie varas un latviešu pilsonisko spēku konsolidēšanos ap Latvijas neatkarības ideju. Politiskā polarizācija, iezīmējot divus galvenos politiskās attīstības virzienus - lielinieciski internacionālistisko un 
pilsoniski nacionālo -, pilnībā izkristalizējās Krievijas Satversmes sapulces sanākšanas laikā 1918. gada 18.-19. janvārī. Tonakt Latviešu pagaidu nacionālās padomes pārstāvis Jānis Goldmanis no tribīnes paziņoja par to, ka Latvija vairs nav Krievijas iekšējais jautājums un par tās likteni Krievija vairs nevar lemt, bet dažas stundas vēlāk lielinieki, kuru vidū bija arī latviešu strēlnieki, padzina Satversmes sapulci (Goldmanis 1934, 26-30).

\section{LATVIJA 1917. GADĀ}

Ziemassvētku un Janvāra kaujām sekojusī Februāra revolūcija nesa radikālus demokrātiskus pārveidojumus Krievijā un līdz ar to arī neokupētajā Latvijas daḷā. Par demokrātijas idejām (konstitūciju un patvaldības atcelšanu, brīvām vēlēšanām, politisko partiju veidošanu u. c.) bija izliets daudz asinu 1905. gada revolūcijas laikā, bet tagad tās sabiedrībai gluži vai pašas iekrita klēpī. Tas daudziem bija pārsteiguma un vienlaikus liela prieka un pārspīlētu cerību avots. Nākamais gads pierādīja, ka sabiedrība, kura nezināja, kas ir aktīva politiskā dzīve, nebija gatava ne pašai revolūcijai, ne tās nestajai demokrātijai.

Salīdzinājumā ar Krieviju Latvija šajā laikā atradās vēl sarežğìtākā situācijā. Jau pusotru gadu karadarbība to bija sašḳēlusi divās dạ̦ās. Frontes līnija bija sastingusi Daugavas krastos. Latvija bija zaudējusi pusi savu iedzivotāju mobilizācijās, kara darbībā, evakuācijās un bēgḷu gaitās. No aptuveni 2,5 miljoniem iedzīvotāju, kas Latvijas teritorijā dzīvoja 1913. gadā, bija atlikuši kādi 1,3 miljoni. ${ }^{1}$ Vācu okupētajā Kurzemē un Zemgalē nekāda politiskā darbība nebija iespējama, un šì Latvijas daḷa palika izolēta ne vien no revolucionārajiem notikumiem Krievijā, bet arī no plašākas politiskās dzīves un nākotnes ceḷu meklējumiem līdz pat 1918. gada rudenim.

Latgalei, neapšaubāmi, 1917. gadā bija svarīga loma; un arī pretēji 1917. gadam Latgales vēsturē bija īpaša nozīme. Tieši šajā gadā Latgale un latgalieši pirmo reizi iznāca uz vēstures skatuves kā politisks subjekts ar savu gribu, paužot savu vienotību ar pārējo latviešu nāciju un prasot apvienošanos ar Kurzemi un Vidzemi. Zināmā mērā mēs varētu teikt, ka tieši tad, 1917. gada pavasarī, arī dzima latvieši kā politiska nācija mūsdienu izpratnē - kā vienība, kas apvieno visus latviešu apdzīvotos novadus. Turpmāk neviens politiskais spēks, pat ne lielinieki vai konservatīvie un provāciskie politiki nevarēja ignorēt Latgales jautājumu.

Krievijas Pagaidu valdība, kas nāca pie varas pēc cara Nikolaja II atteikšanās no troṇa, nespēja adekvāti novērtēt vēsturiskos procesus, kas bija sākušies agrākās impērijas plašumos. Attieksme pret Latgali, ignorējot tās prasības ne tikai atdalīties no Vitebskas gubern,as, bet arī pievienoties 
Baltijas gubernāam, bija viens no pirmajiem signāliem, kam vajadzēja latviešu konstruktīvi noskan,otos politiķus padarīt uzmanīgus.

\section{VIDZEME 1917. GADĀ}

Vidzemei Latvijas 1917. gada vēstures notikumos bija sevišḳa loma. Rīga līdz pat tās krišanai Vācijas rokās 1917. gada septembra sākumā kḷuva par latviešu politiskās dzīves neapšaubāmu centru. Tomēr svarīga nozīme bija arī Cēsīm, Valmierai un Valkai. Pēc Rīgas krišanas Valka kḷuva par jaunu politiskās dzīves centru, sava veida Latvijas neoficiālo galvaspilsētu, lai gan Cēsis un Valmiera arī nezaudēja savu nozīmi.

Vidzemei, līdzīgi kā Kurzemei un Latgalei, šajā laikā arī bija jāpārvar daudz grūtību un izaicinājumu. Vidzeme visu 1917. gadu atradās piefrontes joslā, kas jau pats par sevi nozīmēja ārkārtējus apstākḷus iedzīvotājiem. Šeit koncentrējās ievērojami militārie spēki - Krievijas 12. un 1. armija, kas kopā ar aizmugures iestādēm veidoja gandrīz miljonu karavīru. Tolaik Rīgā un Vidzemē dzīvoja arī liels skaits bēg̣̣u, ne tikai no Kurzemes un Zemgales, bet arī no Lietuvas, Polijas un Baltkrievijas. Daudzi no viņiem bija nodarbināti pozīciju būves darbos.

Stāvoklis laukos bija grūts, saimniekošanu apgrūtināja armijas klātesamība un karadarbības tuvums. Situācija sevišḳi kritiska kḷuva pēc Rīgas zaudēšanas, armijas un transporta sistēmas dezorganizācijas. Atkāpšanās laikā karavīru bandas nodarbojās ar laupīšanu un postīšanu. Pēc frontes stabilizēšanās nāca jauna problēma - pārtikas un kurināmā trūkums. 1917. gada rudenī, transporta sistēmas sabrukuma dēḷ (bija apgrūtinātas dzelzceḷa kravu piegādes) dažviet izcēlās bads un pārtikas sāka trūkt pat armijai. Sociālajā, ekonomiskajā un politiskajā haosā slīgstošā Krievija vairs nevarēja uzturēt daudzmiljonu armiju. Tā sāka brukt, un to nācās pakāpeniski demobilizēt. Bez uztura palikušie karavīri kḷuva par vēl lielāku draudu civiliedzīvotājiem.

Saspringtā situācija Vidzemē nenoliedzami radikalizēja vietējos iedzīvotājus. Politisko stāvokli vēl vairāk pasliktināja agresīvā un bezatbildīgā lielinieku propaganda un aǵitācija. To veicināja ne tikai tradicionāli spēcīgās sociāldemokrātijas pozīcijas Latvijā, bet arī Krievijas 12. armijas atrašanās Vidzemē, kas sargāja vārtus uz revolūcijas šūpuli - Petrogradu. Cīṇa par varu Krievijā sākās tieši šeit - kas kontrolēja 12. armiju un plašāk - Ziemeḷu frontes armijas, kuras izvietojās Vidzemē un Latgalē, tas lielā mērā varēja arī kontrolēt notikumus Petrogradā. Tādēl šeit bija īpaši intensīva politiskā cīn,a, kuras mērḳis bija "demokratizēt" un "revolucionarizēt" karaspēku un arī vietējos iedzīvotājus. 
Tolaik Krievijā spēcīgākajai politiskajai partijai - sociālistiem revolucionāriem (eseriem) - līdz pat 1917. gada beigām bija noteicošā loma galvenajās 12. armijas vēlētajās institūcijās. Tādēḷ nav jābrīnās, ka lielinieki ieguldijja milzu lỉdzekḷus un pūles, lai iekšěji sagrautu šo armiju un savā pusē pārvilinātu gan latviešu strēlniekus, gan vietējos iedzīvotājus. Šis process sākās jau 1917. gada aprīlī, kad dzimtenē no trimdas Šveicē atgriezās Ḷeṇins, pasludinot savas radikālās "Aprīla tēzes", kurās izslēdza iespēju sadarboties ar Krievijas Pagaidu valdību. No trimdas un izsūtijuma atgriezās arī latviešu lielinieki, kuri, sekojot L̦eņina nospraustajai politiskajai līnijai, atteicās meklēt kompromisu ar demokrātiski noskaņotajiem spēkiem. Sākās nesaudzīga cīṇa demokrātiski vēlētajās institūcijās un jaunu, lieliniekiem lojālu politisko struktūru (strādnieku, zaldātu un bezzemnieku padomes) veidošana. Var teikt, ka līdzīgi kā Krievijā, kur savstarpēji konkurēja Pagaidu valdība un radikāli noskaņotā Petrogradas strādnieku un zaldātu padome, arī Latvijā no 1917. gada aprīla-maija sākās "divvaldības" periods.

Martā jau bija nodibinātas strādnieku deputātu padomes Valmierā, Valkā, Alūksnē, Rūjienā un citviet. Aprị̣la sākumā Valmierā notikušā sapulcē izveidoja Vidzemes Pagaidu zemes padomi, kas pārṇēma līdz tam pastāvošãs Vidzemes landrātu kolēgijas un Vidzemes landtāga tiesības un funkcijas. Rīgā tika dibināta viena politiskā partija pēc otras. Maija beigās Vidzemes lauksaimniecības biedrību pārstāvju kongress Valkā, kas apvienoja vairāk nekā 200 lauku kooperatīvu, lēma par Latviešu zemnieku savienības izveidošanu, kas kḷuva par otru spēcīgāko politisko spēku neokupētajā Latvijas dạ̣ā visa 1917. gada garumā (un arī vēlāk, līdz pat 30. gadu sākumam). Visās vasarā un rudenī notikušajās vēlēšanās vinii saṇēma ievērojamu vēlētāju atbalstu, zaudējot tikai Latvijas Sociāldemokrātijai, kurā valdošās pozīcijas bija sagrābuši lielinieki.

\section{LIELINIECISMA VILNIS LATVIJĀ}

1917. gads parasti asociējas tieši ar lielinieku panākumiem, ko var apzīmēt arī kā lieliniecisma vilni. ${ }^{2}$ Viṇi ne tikai uzvarēja visās notikušajās dažādu līmeṇu pašvaldības un Krievijas parlamenta (Satversmes sapulces) vēlēšanās ${ }^{3}$, bet arī pārṇēma kontroli pār strēlnieku pulkiem un visām nozīmīgākajām institūcijām. Kāds bija lielinieku panākumu iemesls?

Te varētu minēt vairākus iemeslus: lielinieku populistiskie lozungi (miers, maize, zeme, tautu pašnoteikšanās), kuri savaldzināja kara nogurdināto sabiedrību; milzīgi finansiālie resursi, kurus varēja izmantot propagandai un aǵitācijai; radikāla un dzelžaini ieturēta politiskā taktika. Raugoties uz lielinieku darbību 1917. gadā, mēs varam vilkt paralēles ar to, kā lielinieki pārṇēma kontroli pār Latvijas Sociāldemokrātijas 
partiju 1913. gadā Briseles kongresā (Kalniņš 1993, 123-126). Lai gan partijas vairākumu veidoja mazinieki jeb mērenāk un demokrātiskāk noskaņotie sociāldemokrāti, lielinieki ar mahināciju palīdzību panāca niecīgu pārsvaru partijas Centrālkomitejā un pēc tam nekaunīgi sāka diktēt noteikumus visiem pārējiem.

1917. gadā šo viņu metodi turpināja izmantot gan pašu partijā (kas pēc gada noveda partiju pie sašḳelšanās divās daḷās), gan attiecībā uz strēlniekiem un dalību pašpārvaldes institūcijās. Visur, kur lielinieki ar savu agresīvo aǵitāciju, bezatbildīgo demagoǵiju, intrigām un neierobežotajām finansiālajām iespējām varēja iegūt kaut nelielu pārsvaru pār konkurentiem, viṇi nedemokrātiski un pilnīgi ignorējot citu uzskatus sāka diktēt savu gribu. Šì iemesla dēḷ no Vidzemes Zemes padomes 1917. gada rudenī aizgāja pilsoniskā frakcija, lai izveidotu Latviešu pagaidu nacionālo padomi; šĩ iemesla dēḷ nacionāli noskan,otie virsnieki izveidoja Iskolastrelam alternatīvu karavīru organizāciju - Latvju kareivju nacionālo savienību. Var teikt, ka lielinieki ar šādu taktiku nošāva uzreiz divus zaḳus - palielināja savu politisko ietekmi un diskreditēja demokrātijas ideālus, pret kuriem lielinieki vienmēr principiāli nostājās.

Arī paši lielinieki, kā jau iepriekš minēts, veidoja alternatīvas varas struktūras - bezzemnieku padomes, vēlāk izveidoja arī Latvijas strādnieku, zaldātu un bezzemnieku padomes izpildkomiteju jeb Iskolatu, kas pēc lielinieku apvērsuma, pēc tam, kad visas lielākās Vidzemes pilsētas bija ieņēmuši latviešu strēlnieku pulki, pārn̦ēma varu neokupētajā Latvijas daḷā. Demokrātiski vēlēto Vidzemes Zemes padomi lielinieki vienkārši likvidēja. Lielinieciskais režīms Latvijā 1917. gada beigās un 1918. gada sākumā vēstures literatūrā ir pazīstams arī kā Iskolata republika un pastāvēja kā nosacīti autonoms valstisks veidojums Padomju Krievijas sastāvā.

\section{POLITISKIE CENTRI VIDZEMĒ}

Ja mēs skatāmies uz tālaika politisko grupēšanos geogrāfiskā ziṇā, tad Cēsis pēc Rīgas zaudēšanas kḷuva par izteikti lieliniecisku centru - šeit darbojās Iskolastrels un 12. armijas Kara revolucionārā komiteja, kas gatavoja bruņoto sacelšanos visā Vidzemē. Šì bija arī pirmā pilsēta, kur pēc Oktobra apvērsuma iesoḷoja latviešu strēlnieku pulki, lai atbalstītu lieliniekus.

Otrs, sākotnēji varētu teikt pat pretlielinieciskais, centrs bija Valka. Šeit atradās 12. armijas štābs, armijas padomes izpildkomiteja (Iskosols), te aktīvi darbojās nacionāli noskan,otie spēki - Latvju kareivju nacionālā savienība, iznāca pilsoniskie laikraksti. Pēc lielinieku apvērsuma šeit izveidojās Dzimtenes un revolūcijas glābšanas komitejas nodaḷa, kura apvienoja dažādus politiskos un sabiedriskos spēkus, kas nosodīja lielinieku apvērsumu. 
Tomēr viņiem nebija reāla militāra spēka un 21. novembrī pilsētu bez kaujas ieñēma latviešu strēlnieki. Tūlīt pat Valkā par varas pāriešanu lielinieku padomju rokās paziņoja Iskolats.

Interesanti, ka tieši Valkā latviešu pilsoniskās aprindas nolēma sarīkot Latviešu pagaidu nacionālās padomes pirmo sesiju 29. novembrī, kura sākotnēji bija iecerēta Valmierā 11. novembrī, bet lielinieku apvērsuma dēl to atcēla (Līdums 1917, 15.(28.) nov.). Tā bija paradoksāla situācija, kad abi galvenie naidīgie politiskie virzieni varēja Valku uzskatīt par savu "galvaspilsētu”. Šeit atradās gan Iskolats, gan Latviešu pagaidu nacionālā padome. Tiesa gan, lielinieki visai drīz pret Nacionālpadomi sāka vērst represijas, tāpat kā pret visām nacionāli noskan,otajām partijām un laikrakstiem. Tomēr viņi pieḷāva Nacionālpadomes dibināšanu savā degungalā, nosūtot uz sesiju savus novērotājus.

Rakstot par Nacionālpadomes dibināšanu, parasti aizmirst, ka šajā laikā notika kāds cits svarīgs notikums, kas lieliniekiem varēja šķist daudz svarīgāks - tas bija 12. armijas padomes ārkārtas kongress, kuram bija jāizlemj, vai armija ies kopā ar lieliniekiem vai pret. Nacionālpadomes dibināšanas laikā Valkā vēl darbojās vecais Iskosola sasaukums, kur l,oti spēcīgas pozīcijas bija sociālrevolucionāriem jeb eseriem (Līdums 1917, 15.(28.) nov.). Līdz ar to lieliniekiem nācās samierināties ar Nacionālpadomes izveidošanu. Tiesa gan, neatkarības pasludināšana vai valdības izveidošana šādos apstākḷos faktiski nebija iespējama, lai gan atsevišḳi Nacionālpadomes pārstāvji par to iestājās. Ir pilnīgi skaidrs, ka neatkarības pasludināšanas gadījumā Nacionālpadomes pārstāvjus tūlīt pat arestētu.

\section{SECINĀJUMI}

1917. gada nogalē Latvija stāvēja krustcelēs. Tai bija trīs ceḷi: ar vāciešiem, ar L,eņinu un ar lieliniekiem-internacionālistiem vai ar pilsoniski nacionālajiem spēkiem, kuri bija vīlušies Krievijā, kas slīga haosā un lieliniecismā un orientējās uz Rietumu sabiedrotajiem. Visi ceḷi bija iespējami, jo aiz katra grupējās noteikti politiskie spēki un Latvijas iedzīvotāju grupas. Turpmāko noteica ārēji apstākḷi - lielinieku neveiksmīgā politika, it seviškịi Brestas miers, un sekojošā Vācijas sakāve Pirmajā pasaules karā. Tas, ka latviešu politiḳi šos ārējos apstākḷus spēja sekmīgi izmantot neatkarīgas valsts pasludināšanai un izveidošanai, lielā mērā notika, pateicoties arī 1917. gada gūtajai politiskās cīṇas pieredzei. 


\section{SAĪSINĀJUMI}

Iskolats - Latvijas strādnieku, zaldātu un bezzemnieku padomes izpildkomiteja.

Iskosols - Krievijas 12. armijas padomes izpildkomiteja.

\section{IZMANTOTIE AVOTI UN LITERATŪRA}

Andersons, E., 1967. Latvijas vēsture, 1914-1920. Stokholma: Daugava.

Blūzma, V., 1994-1995. Pateiktais un noklusētais: lieliniecisma vilnis Latvijā (1917.-1919.) vēstures pētijumos. Latvijas Vēsture, 1-4.

Goldmanis, J., 1934. Latviešu strēlnieki vēstures svaru kausos un deklarācija Taurijas pilī par atdalǐšanos no Krievijas. Rīga: Latviešu veco strēlnieku biedrība.

Kalniņš, B., 1993. Latvijas Sociāldemokrātijas 50 gadi (1904-1954). Stokholma: Memento.

Latviešu Pagaidu Nacionālpadomes sanākšana Valkā. Lìdums, 15 (28), 1917.

Šiliņ̌̌, J., 2013. Padomju Latvija, 1918-1919. Rīga: Vēstures izpētes un popularizēšanas biedrība.

Šiliņš, J., 2015. Zināmākais latvietis Petrogradā. Jāņa Goldmaņa politiskā darbība Krievijā un Latvijā. Latvijas Arhivi, 3/4, 161-196.

XII. Armijas kongress. Lìdums, 1 (14), 1917.

\section{ATSAUCES UN PIEZĪMES}

${ }^{1}$ Aptuveni $250-300$ tūkstoši cilvēku tika mobilizēti, apmēram 850 tūkstoši devās bēgḷu gaitās vai tika evakuēti, vēl aptuveni 100 tūkstoši gāja bojā karadarbībā vai no tās izraisītajām sekām. Skat.: Andersons, E., 1967. Latvijas vēsture, 1914-1920. Stokholma: Daugava.

${ }^{2}$ Blūzma, V., 1994-1995. Pateiktais un noklusētais: lieliniecisma vilnis Latvijā (1917.-1919.) vēstures pētījumos. Latvijas Vēsture, 1-4.

${ }^{3}$ Vidzemes Zemes padomes vēelěšanās lielinieki saņēma 61\% balsu, apriņku padomju vēlēšanās - no 71 līdz 76\%, Krievijas Satversmes vēlēšanās 72\%. Skat.: Andersons, E., 1967. Latvijas vēsture, 1914-1920. Stokholma: Daugava.; Šilinšs, J., 2013. Padomju Latvija, 1918-1919. Rīga: Vēstures izpētes un popularizēšanas biedrība. 


\title{
THE YEAR OF THE GREAT QUEST: VIDZEME IN THE POLITICAL PROCESSES OF 1917
}

\author{
JĀNIS ŠILIN̦Š \\ Dr. hist., leading researcher at the State History Archives of Latvia, researcher at \\ the Institute of Social, Economic and Humanities Research of Vidzeme University \\ of Applied Sciences \\ Email: Janis.Silins@arhivi.gov.lu
}

\begin{abstract}
The paper provides an insight into the political processes taking place in Vidzeme (in the Latvian-inhabited part of Livonia Governorate) in 1917. The First World War tore the territory of Latvia in two as the Kurzeme and Vidzeme regions fell under the German occupation. After the February Revolution and the abdication of Tsar Nicholas II the unoccupied part of Latvia (Latgale and Zemgale) became an arena of dynamic political processes. On the one hand, Bolshevism started rapidly to grow in popularity ("a wave of Bolshevism") in April 1917. On the other hand, in the democratic civil and later also Social Democratic Latvian circles the idea of the independence of Latvia developed. The paper evaluates the factors affecting these processes and examines the location of political centres in Vidzeme in 1917.
\end{abstract}

Keywords: The First World War, the February Revolution, a wave of Bolshevism, independence idea, the Latvian National Provisional Council.

\section{SUMMARY}

1917 was a year of grandiose political and social transformations both in Russia and in the eastern part of Latvia, which was not occupied by the German army. For Latvia the year 1917 started with the Christmas Battles on $5^{\text {th }}$ January when Tsar Nicholas II was still holding power and ended with the Bolsheviks coming to power and the consolidation of Latvian civil forces around the idea of Latvia's independence.

The February Revolution introduced radical democratic transformations in Russia. The following year proved that the society, which was unfamiliar with active political life, was not ready either for the revolution itself, or the democracy that it brought. Compared to Russia, Latvia was in a very 
complicated situation at that time. The war had torn it in two. The country had lost a half of its population due to mobilisations, warfare, evacuations and displacements. From the population of approximately 2.5 million in 1913, only 1.3 million had remained in Latvia. In rural areas the situation was grave, agricultural activities were made difficult by the presence of the army and the proximity of warfare. Situation became particularly critical after the loss of Riga city and the disorganisation of the army and transportation system. During the withdrawal, the gangs of Russian troops went about pillaging and demolishing. After the stabilisation of the front-line a new problem emerged - the shortage of food and fuel. In the autumn of 1917, due to the collapse of the transportation system famine broke out in some places and even the army started to suffer food shortages.

The strained situation in Vidzeme no doubt radicalised the local population. It was in Vidzeme that the fight for power in Russia actually begun: the one who controlled the $12^{\text {th }}$ Russian Army and in a broader context - the armies of the Northern Front, could to a large extent control developments in Petrograd, too. For this reason the Bolsheviks invested huge resources and effort to disarrange internally the troops dislocated in Vidzeme and to lure both the Latvian riflemen and the local population to their side.

The Bolsheviks not only won all the different level elections that were held to the local authorities and the parliament (the Russian Constitutional Assembly) but also established control over the Latvian riflemen regiments and all the major institutions. The Bolsheviks benefitted from their populist slogans (peace, bread, land, the self-determination of peoples), the huge financial resources and the iron hard political tactics.

Vidzeme region played a special role in the historical events of 1917. After the fall of Riga, Valka emerged as a new centre of political life, as a sort of an unofficial capital of Latvia. Interestingly, it was in Valka that the nationalist-oriented Latvian circles decided on $29^{\text {th }}$ November to hold the first session of the Latvian National Provisional Council. Situation was paradoxical: the two mutually hostile political orientations could claim Valka as their 'capital'. Valka housed the headquarters of both Iskolat and the Latvian National Provisional Council.

Publications about the foundation of the National Council tend to forget the extraordinary congress of the council of the $12^{\text {th }}$ Army that was taking place in Cēsis at that very moment. It forced the Bolsheviks to reconcile themselves with the foundation of the National Council. Admittedly, under such conditions the declaration of national independence or formation of a government was practically impossible, although some members of the National Council advocated in favour of it. 
At the end of 1917 Latvia was standing at the crossroads. There were three paths for it to choose from: the one together with the Germans, the one with Lenin and Bolsheviks-internationalists or the one with nationalist civil forces who were disappointed in the great chaos and in Russia's sinking in Bolshevism and oriented themselves at the western allies. The favourable historical circumstances allowed declaring Latvia's independence on $18^{\text {th }}$ November 1918. 


\title{
VĀCIJAS LOMA LATVIJAS UZṆEMŠANĀ NATO (1991-2004)
}

\author{
VIESTURS RASNACIS \\ Mg. hist., Latvijas Kara muzeja vēsturnieks \\ E-pasts: viesturs.rasnacis@gmail.com
}

\begin{abstract}
ANOTĀCIJA
Pēc PSRS sabrukuma demokrātisko Rietumu valstu politiḳiem bija skaidrs, ka neatkarību atguvušajām Austrumeiropas valstīm būs nepieciešama jauna, uz demokrātijas principiem balstīta politiskā un drošības sistēma. Baltijas valstīs netika lolotas ilūzijas par Krievijas Federācijas atbalstu, tādē! tās neparakstīja Belovežas vienošanos un nepievienojās Neatkarīgo Valstu Sadraudzībai (NVS), tā vietā vēršoties pie Rietumu sabiedrotajiem ar lūgumu tikt uzṇemtām NATO. Latvijas Republikai būtisku atbalstu sniedza Vācijas Federatīvā Republika, kas, veidojot savu ārpolitiku, aizstāvēja Baltijas valstu intereses Rietumeiropā. Latvijas uzṇemšana NATO bija ilgs un sarežğīts process, ko apgrūtināja ne tikai politiskie, bet arī sociālekonomiskie un saimnieciskie apsvērumi. Arī Vācijā jautājums par Latvijas uzṇemšanu NATO dažādās sabiedrības grupās tika vērtēts dažādi, tomēr tieši Vācijai bija nozīmīga un Eiropas ietvaros varētu spekulatīvi teikt, ka pat noteicoša loma šī procesa pozitīvajā iznākumā.
\end{abstract}

Atslēgas vārdi: Latvija, Vācija, NATO, mūsdienu vēsture, starptautiskās attiecības.

\section{IEVADS}

Pētījums ir veltīts Vācijas lomas izpētei Latvijas uzņemšanā Ziemel̦atlantijas līguma organizācijā (NATO). Lai arī mūsdienu Eiropas un Rietumu sabiedrībai kopumā Baltijas valstu dalība organizācijā varētu šķist pašsaprotama, 90. gadu sākumā viedokḷi par to krasi atšḳīās un Rietumu valstu atbalsts Baltijas valstu uzņemšanai nebija vienprātīgs. Temats savu politisko aktualitāti saglabā joprojām, politiskajai diskusijai atsākoties pēc politiskās situācijas saasināšanās Ukrainā 2013. gada novembrī, Krievijas Federācijas īstenotās Krimas aneksijas un karadarbības sākuma 
Ukrainas austrumu dạ̣ā, kas aktualizēja jautājumu arī par Ukrainas uzņemšanu NATO. Vācijas loma Latvijas uzņemšanā NATO ir arī zinātniski aktuāls temats, ko tēmas specifikas dēḷ pagaidām galvenokārt ir pētījuši politologi un starptautisko attiecību speciālisti, līdz ar to ir tikai logiski pieņemt, ka ar laiku tai pievērsīsies arvien vairāk vēsturnieku.

Pētījumā hronolog̣iski apskatīts laika posms no 1991. gada 28. augusta, kad tika atjaunoti Latvijas un Vācijas diplomātiskie sakari, līdz 2004. gada 29. martam, kad Baltijas valstis sekmīgi iestājas NATO.

\section{STARPTAUTISKĀ SITUĀCIJA UN LATVIJAS UN VĀCIJAS SADARBĪBA (1991-2004)}

Līdzīgi, kā tas bija pēc Pirmā pasaules kara beigām, Krievijas impērijas sabrukuma un Baltijas valstu neatkarības pasludināšanas 1918. gadā, tā arī pēc Padomju Savienības sabrukuma un neatkarības atgūšanas 1990. gadā Baltijas valstis, tajā skaitā Latvija, bija ieinteresētas ātrā un veiksmīgā integrācijā vienotā un drošā Eiropas sistēmā (Feldmanis 2016, 11). Tomēr Rietumu valstīs politiḳi visai pamatoti uz bijušă komunistiskā bloka valstu iestāšanos NATO un Eiropas Savienībā raudzijāàs ar zināmu skepsi - padomju okupācija šîs teritorijas bija atstājušas nabadzībā un dzives līmenis tajās bija ievērojami zemāks nekā Rietumos (Judt 2005, 718). Tāpat padomju režīms bija atstājis būtisku ietekmi uz šo valstu politisko sistēmu, līdz ar to pastāvēja draudi, ka Krievija varētu mēǵināt pasliktināt situāciju Baltijas valstīs, tādējādi vājinot arī Rietumu valstu pozīcijas (Rühle 2000, 637). Turklāt pēc aukstā kara beigām radās arī jautājums par NATO nepieciešamību.

Vācijas Federatīvā Republika diplomātiskās attiecības ar Latvijas Republiku atjaunoja 1991. gada 28. augustā - veselu nedēlu pēc 21. augusta puča Maskavā (VFR ārlietu ministra personiskā nota). Šādu "kavēěanos" ietekmēja divi būtiski faktori. Kā pirmais jāmin Padomju Savienības Komunistiskās partijas Centrālās komitejas ǵenerālsekretāra un PSRS prezidenta Mihaila Gorbačova loma un atbalsts 1990. gada 3. oktobrī ìstenotajā Vācijas apvienošanā. Un, lai arī Vācija Maskavai izmaksāja milzīgas summas (kopumā aptuveni 70 miljardus vācu marku, no kurām 17 miljardi bija paredzēti padomju karaspēka izvešanai no bijušās Austrumvācijas teritorijas), bija būtiski saglabāt labas attiecības ar brūkošo impēriju (Hamm 1992). Otrs faktors bija vispārējā situācija Austrumeiropā - Rietumu laikabiedru skatījumā bijušo padomju republiku aiziešana pa demokrātijas ceḷu nešķita pašsaprotama, Padomju Savienības sabrukums varēja izraisìt asiņainus etniskos konfliktus, kā tas bija redzams Balkānu pilsoņu karos pēc Dienvidslāvijas sabrukuma (Kuper 1999, 320). Būtisks faktors ir arī 
kreiso politisko spēku, it īpaši ietekmīgās Sociāldemokrātu partijas (Die Sozialdemokratische Partei Deutschlands), vēsturiskā tradīcija ar Krieviju uzturēt labas attiecības.

Pēc Padomju Savienības sabrukuma vācu uzņēmumi ievērojami izvērsa savu darbību Austrumeiropas valstīs, īpaši pievēršot uzmanību ar vācu kultūru cieši saistītajām Baltijas valstīm, galvenokārt Latvijai un Igaunijai. Vācu investīciju ieplūdumam Latvijas ekonomikā sekoja arī Vācijas Ārlietu ministrijas principā vārdiskais atbalsts Latvijas eventuālai uznemšanai NATO un Eiropas Savienībā (Grundlinien der Außenpolitik). Šeit gan jāatzīmē, ka kancleru Helmuta Kola (Helmut Kohl, 1982-1998.) un Gerharda Šrēdera (Gerhard Schröder, 1998-2005) vai vēlāk kancleres Angelas Merkeles (Angela Merkel, kopš 2005) administrācija vārdos bija krietni atturīgāka. Jānorāda, ka Vācijā atbalsts Baltijas valstu kandidatūrai NATO nebija vienprātīgs, daḷa politisko spēku un uzn̄ēmēju vēlējās saglabāt labas attiecības ar Krieviju, to lieki neprovocējot. Arī Latvijā, n,emot vērā vēl joprojām spēcīgo padomju mantojuma ietekmi politiskajās aprindās un sabiedrībā, nebija simtprocentīga atbalsta Latvijas dalībai NATO, tomēr noteicošās politiskās un zinātniskās aprindas bija pārliecinātas, ka Baltijas valstu politiskā attīstība noteikti saistāma ar Rietumu valstīm. Piemēram, tā brīža Ārpolitikas institūta direktors Atis Lejiņ̌̌ (1992-2011) pamatoti argumentēja, ka NATO ir vienīgais un visdrošākais Latvijas drošības garants (Feldmanis 2016, 93).

Rietumvācijā pēc Otrā pasaules kara beigām uzvarētājvalstis kā daḷu no denacifikācijas procesa izvērsa plašu ideologisko kampaṇu, savukārt Padomju Savienība to pašu darīja Austrumvācijā, tādējādi radot divas pilnīgi pretējas politiskās sistēmas, kas likumsakarīgi bija redzams arī pēc Vācijas apvienošanas. Latvijas vēsturnieks Raimonds Cerūzis norāda, ka Vācijas vēstures pētnieki (ar retiem izṇēmumiem) par Rietumu valstu ideoloğisko darbu Rietumvācijā raksta ievērojami mazāk (Cerūzis 2015, Nr. 2). ${ }^{1}$ Lai arī tas varētu šksist pretrunīgi ar kopējo aukstā kara situāciju, denacifikācijas rezultātā liela dạ̣a Rietumvācijas sabiedrības uz jebkādu militāro agresiju vai bruņošanos skatījās skeptiski. Tas arī daḷēji izskaidro vācu sabiedrības vienas daḷas nevēlēšanos paplašināt NATO uz austrumiem un provocēt Krieviju, kuru uzskatīja par potenciālu ekonomisko partneri (Kenens 2016). Vācijas un Krievijas ekonomiskās attiecības patiešām uzlabojās (Feldmanis 2016, 96), ko Baltijas valstis neuztvēra par labvēlīgu zīmi viņu uzn,emšanai Rietumu valstu pulkā. Šajā sakarā jāatzīmē arī diskusijas pašā Vācijas sabiedrībā par Bundesvēra (Bundeswehr - VFR Bruṇotie spēki) lomu Eiropā pēc aukstā kara beigām. Daḷa vāciešu uzskatīja, ka tiešas kara briesmas vairs nedraud un ir nepieciešams ievērojami samazināt savus brun,otos spēkus, kur nu vēl veicināt to izaugsmi vai ieguldīt Baltijas valstīs (Conze 2009, 877-878). Šis laiks sakrita ar vispārējo 90. gadu sākuma 
Rietumeiropas NATO dalībvalstu "sevis meklēšanas" posmu (Asmuss 2004, 35).

Kā alternatīva drīzai uzṇemšanai NATO tika piedāvāta "Partnerattiecības mieram" (Partnership for Peace) programma, kas tika uzsākta 1994. gada 10.-11. janvāra samitā Briselē un principā paredzēja veidot stabilu sadarbību miera uzturēšanai ar bijušajām padomju republikām. Vairumam Austrumeiropas valstu, tai skaitā Latvijai, šai programmai bija svarīga nozīme tās sagatavošanai eventuālai dalībai NATO. Tiesa, ne visas NATO dalībvalstis Austrumeiropas kontekstā uz šo programmu skatījās ar tādiem mērkiiem, Vācija bija viena no tām, kas oficiāli iestājās par šīs programmas darbības formātu kā alternatīvu reālai dalībai NATO Baltijas valstīm.

Neraugoties uz to, Vācijas intelektuāḷu aprindās plaši tika runāts par Vācijas vēsturisko atbildību Baltijas valstu priekšā. Tika kritizēts MolotovaRibentropa pakts un uzsvērts, ka vāciešu pienākums ir atbalstīt neatkarīgās Baltijas valstis, nepielaujot to sabrukumu vai to iedzīvotāju nemierus (Herold 2005, 294). Šeit ir jāmin britu vēsturnieces Kristīnes Redmenas (Kristina Readman) koncepcija par Vācijas ārpolitiku pēc 1990. gada autore uzskata, ka apvienotā Vācija vienkārši turpina realizēt vēsturisko "Ostpolitik" ("Austrumu politika"), mēóginot palielināt savu ietekmi un nostiprināt savas pozīcijas uz robežas ar Krieviju (Readman 2004, 145). Pēc autores domām, zināma taisnība ir abiem Vācijas rīcības skaidrojumiem: vācu sabiedrība patiešām bija gatava gan risināt sāpīgos 20. gadsimta jautājumus, vēloties palīdzēt no nacistiskās Vācijas cietušajām tautām, gan gūt ekonomiskas priekšrocības un palielināt politisko ietekmi Eiropā.

\section{VĀCIJAS ATBALSTS LATVIJAI CEḶĀ UZ NATO}

Vācijas kanclers Helmuts Kols savās atmiṇās, aprakstot laiku vēl pirms Vācijas apvienošanas, atzīmējis, ka sarunās ar Padomju Savienību viņa prioritāte bija panākt tās piekrišanu Vācijas apvienošanai (lai arī oficiāli pabeigts 1990. gada 3. oktobrī, pats process vēl nav noslēdzies un okupācijas gadu sekas ir jūtamas arī mūsdienās). ${ }^{2}$ Atklāta atbalsta izrādīšana nesen savu neatkarību deklarējušo Baltijas valstu uzṇemšanai NATO Padomju Savienībā varētu tikt uztverta kā provokācija, līdz ar to šādu soli H. Kols uzskatīja par pārāk riskantu (Kohl 2014, 198). Jāṇem vērā arī reālpolitiskais aspekts - kā jau minēts, vācieši, it ìpaši uzṇēmēji un politiki, loloja cerības par Krieviju kā patstāvīgu partneri kopējās drošības un ekonomikas sfērās (Readman 2014, 159). Bet, neraugoties uz pretrunām dažādās Vācijas aprindās, Vācijas Federālās ārlietu ministrijas (Das Auswärtige Amt) atbalsts Baltijas valstīm kopš 1990. gada bija nemainīgs (Readman 2014, 168). 
1995. gadā Vācijas aizsardzības ministrs Folkers Rue (1992-1998) (Volker Rühe) apmeklēja visas trīs Baltijas valstis, tādējādi paužot tām zināmu atbalstu, tomēr kopumā ministrs izteicās piesardzīgi, formāli dodot priekšroku Višegradas valstu uzņemšanai (Kremp 1995). Savukārt bijušais Vācijas ārlietu ministrs un tā brīža Brīvo demokrātiju partijas (Freie Demokratische Partei jeb FDP) priekšsēdētājs grāfs Oto Lambsdorfs (Otto Graf Lambsdorff) izteicās pārliecinošāk par Baltijas valstu uzṇemšanu NATO un uzsvēra, ka "Vācija ir vēsturiski atbildīga par Baltijas valstu likteni" (Lašas 2010, 81).

Tomēr problēmas Baltijas valstu uzn,emšanai sagādāja ne tikai uz politiskiem apsvērumiem balstīta pretestība, bet arī nepieciešamo uzņemšanas prasību izpilde. Nepietiekošais budžets valsts aizsardzībai, kā arī augstais korupcijas līmenis valsts pārvaldē vājināja Latvijas aizsardzības spējas, kā arī vairoja Rietumu sabiedroto šaubas par to, vai valsts vispār ir spējīga iestāties NATO un pilnvērtīgi pildīt visas saistības, kuras jāuzṇemas katrai dalībvalstij. Pastāvēja nopietnas bažas par to, cik daudz ir izdarīts reālo aizsardzības spēju veicināšanā, uzsverot: lai gan mazai valstij tās nav un arī nevar būt lielas, tomēr netiek izpildītas pat iespēju robežās (Taurēns 2016, 125). Savukārt korupcijas mazināšanai politiskā elite nedeva pienācīgu impulsu, tā nereti pati veicināja un izplatīja korupciju, pildot kādu politisko spēku intereses. Pastāvēja arī ievērojamas sadarbības problēmas pašu Baltijas valstu vidū: kā pamatoti atzīmē vēsturnieks Aivars Stranga, tikai kandidatūra NATO un Eiropas Savienībā tās iegrožoja pārāk nenodoties mazsvarīgām savstarpējām ķildām (Feldmanis 2016, 94).

Kā norādījusi K. Redmena, Baltijas valstu aizsardzības bruņojuma stiprināšanu ievērojami kavēja arī pašas Rietumu valstis, no kurām bija paredzēts pirkt ekipējumu - no Vācijas, Zviedrijas vai Norvēgéijas iepirktā tehnika bija faktiski bez bruṇām, ar minimālām uzbrukuma vai aizsardzības iespējām, principā derīga tikai robežas sargāšanai. K. Redmena izsaka tēzi, ka pamatojums šādam lēmumam bija jau minētā vēlme lieki neprovocēt Krieviju (Readman 2014, 121). Tiesa, tajā pašā laikā 90. gadu otrajā pusē ir novērojamas arvien biežākas Vācijas organizētas militārās apmācības Latvijas virsniekiem. Principā šādam autores viedoklim var piekrist, n,emot vērā tā brīža situācijai zīmīgos pilson,u karus Balkānos, kuri liecināja par sliktu atjaunoto vai jaunizveidoto neatkarīgo valstu pārāk ātrai apbruņošanai. Nestabilas valstis var nebūt spējīgas novērst aukstā kara gados briedušus etniskos konfliktos, pastāvēja bažas par Dienvidslāvijas scenārija atkārtošanos starp latviešiem, lietuviešiem un igaun,iem un viņu teritorijā dzīvojošajiem krieviem.

90. gadu beigās un 2000. gadu sākumā Vācijas atbalsts Baltijas valstīm vēl vairāk pieauga. Bieži notika arī abu valstu pārstāvju konsultatīvas tikšanās, kurās vācieši pauda atbalstu Latvijas eiroatlantiskajai integrācijai, 
piemēram, 2001. gadā no 15. līdz 16. maijam Ārlietu ministrijas valsts sekretārs Māris Riekstiṇš (1993-2004) tikās ar Vācijas diplomātu Dr. Gunteru Ploigeru (Gunter Pleuger), kurš apstiprināja vāciešu pozitīvo attieksmi Latvijas dalībai NATO (LR ĀM 2001. gada gadagrāmatas hronolog̣ija).

2002. gada 11. februārī Vācijas ārlietu ministrs Joška Fišers (1998-2005) (Joschka Fischer) Rīgā tikšanās laikā ar Baltijas valstu ārlietu ministriem apliecināja Vācijas atbalstu visu trīs valstu uzaicinājumam NATO tajā pašā gadā. Jāuzsver, ka šeit atkal parādās tendence Vācijas Ārlietu ministrijai būt pozitīvāk noskan,otai pret Latviju nekā pašai kanclera administrācijai, reizēm pat savstarpēji nonākot nelielās pretrunās (Baltic States 2002).

Lai arī principā formāls, bet kā Latvijas kandidatūru veicinošs notikums jāmin 2002. gada 25. aprị̣̄a balsojums Vācijas parlamentā Bundestāgā (Bundestag), kurā beidzot arī opozīcijas partijas (Kreisie politiskie spēki un Partija par demokrātisku sociālismu) tobrīd uzñēmās iniciatīvu Baltijas valstu uzaicināšanai aliansē NATO konferencē Prāgā (Dauchert 2008, 66).

Par spīti visām grūtībām, 2004. gada 29. martā Latvija kḷuva par pilntiesīgu NATO dalībvalsti, kas, n̦emot vērā tālāko notikumu attīstību pasaulē, viennozīmīgi ir vērtējams kā pozitīvs notikums, jo sevišķi no valsts drošības viedokḷa. Palielinoties tās resursiem un iespējām, Latvijai ir izdevies iegūt stabilāku un nozīmīgāku lomu aliansē, nostiprinot tās austrumu robežu (Taurēns 2016, 229-231). Tās stingro pozīciju attiecībā pret Krieviju vēl jo svarīgāku dara pretestība Vācijā Rietumu valstu uzliktajām sankcijām Krievijai pēc tās īstenotās Krimas aneksijas. Turklāt pētnieki jau atklāti runā par Krievijas izvērsto informatīvo karu Vācijas iedzīvotāju vidū, kura laikā Krievijas vadošie politiskie spēki mēǵina radīt pret sevi pozitīvu attieksmi, ipaši pievēršot uzmanību Vācijas lielākajiem uznēēmumiem (Van Herpen 2015, 13).

Jāsecina, ka, nnemot vērā situāciju, kāda bija izveidojusies Vācijā pēc Otrā pasaules kara un Vācijas apvienošanās 1990. gadā, Vācijas kā Eiropas lielvaras pieaugošo ietekmi, kā arī tās politiskās un ekonomiskās intereses, tās atbalsts Baltijas valstu uzṇemšanai NATO nebija vienprātīgs. Tomēr bija būtiski saglabāt stabilu situāciju Eiropā un dal̦a vāciešu uzskatīja, ka to vēsturisks pienākums ir atbalstìt Baltijas valstu iedzīvotājus, līdz ar to Vācija, tiesa gan, visai piesardzīgi sniedza gan ekonomisku, gan politisku atbalstu Baltijas valstu uzṇemšanai NATO. Bieži rīkojoties kā starpnieks sarunās ar Krieviju, kā arī palīdzot risināt ekonomiskas un iekšpolitiskas problēmas un, visbeidzot, paužot jau atklātu atbalstu, Vācija sniedza būtisku ieguldījumu Latvijas eiroatlantiskajā integrācijā. 


\section{SECINĀJUMI}

Latvijas iestāšanās NATO ir vērtējama kā pozitīvs notikums, kura realizācija prasīja lielas iesaistīto pušu pūles gan pašas kandidātvalsts sagatavošanai, gan starptautiskās sabiedrības pārliecināšanai. Baltijas valstu sekmīga integrācija Rietumu valstu vadošajās struktūrās, par spīti to vēsturiskajām saiknēm ar Rietumiem, tobrīd nebija pašsaprotama, un ir iespējams spriest par iespējamu citādu šo procesu attīstību, ja Baltijas valstis savas iekšējās problēmas nebūtu spējušas vismaz daḷēji atrisināt, Krievija uzvestos agresīvāk vai Rietumu valstu iedzīvotāji gluži vienkārši aukstā kara beigu eiforijā būtu kategoriski nostājušies pret jebkādu NATO paplašināšanu.

Vācijai bija īpaši liela nozīme Latvijas uzņemšanā NATO, jo pēc tās apvienošanās, kḷūstot par vadošo Eiropas lielvaru, viens no tās būtiskākajiem jautājumiem bija stabilitātes nodrošināšana Eiropā. Vācija palīdzēja Baltijas valstīm, risinot gan ekonomiskos, gan juridiskos jautājumus, kā arī veicinot to eiroatlantisko integrāciju. Izmantojot kopīgo vēsturi, tā arī sekmēja kultūras sakaru atjaunošanu un vācu valodas popularizāciju. Lai arī oficiālajā retorikā Vācijas valstsvīri centās nekonfliktēt ar Krieviju, reālajā darbībā tā veicināja Latvijas un pārējo Baltijas valstu attīstību pēc Rietumu liberālās demokrātijas modeḷa un lēnām gatavoja tās uzn,emšanai NATO, kas jo sevišķi parādās Aizsardzības ministrijas dokumentos, kuros var redzēt, kā 90. gadu otrajā pusē arvien pieaug vāciešu organizētās mācības un kursi Latvijas karavīriem. Tiesa, Vācijai šāda sava tirgus un savstarpējās sadarbības paplašināšana ar Latviju bija izdevīga, tādējādi palielinot savu ietekmi Eiropā, savukārt Latvijai Vācijas atbalsts palīdzēja stiprināt tās neatkarību.

Īpaši liela nozīme bija vācu sabiedrības viedoklim - kamēr vairums latviešu savas valsts eiroatlantisko integrāciju vērtēja pozitīvi, vācieši uz Baltijas valstīm raudzījās pietiekoši skeptiski, no vienas puses jūtot vēsturisku atbildību ar nepieciešamību palīdzēt un atbalstìt, bet no otras puses viņi redzēja līdzīgas problēmas, kādas tobrīd pieredzēja ar apvienotajā Vācijā iekḷautajiem austrumvāciešiem, kuri tiem tobrīd bija ievērojams slogs gan ekonomiski, gan politiski. Lai arī Vācija vēl joprojām ir piesardzīgāka nekā, piemēram, ASV, tā tomēr lēni, bet neatlaidīgi ir palielinājusi savu ietekmi gan Eiropā, gan NATO. Bez Vācijas atbalsta Baltijas valstu iestāšanās NATO, visticamāk, būtu bijusi krietni sarežg̀ītāka, jo ne visas Eiropas un Rietumu valstis atbalstīja NATO paplašināšanu un ticēja, ka salīdzinoši nabadzīgās Baltijas valstis spēs pildīt visas nepieciešamās saistības. 


\section{SAĪSINĀJUMI}

$\bar{A} M$ - Ārlietu ministrija

ASV - Amerikas Savienotās Valstis

LR - Latvijas Republika

NATO - Ziemeḷatlantijas līguma organizācija (North Atlantic Treaty Organization)

PSRS - Padomju Sociālistisko Republiku Savienība

VFR - Vācijas Federatīvā Republika

\section{IZMANTOTIE AVOTI UN LITERATŪRA}

Asmuss, D. R., 2004. NATO paplašināšanās. Rīga: Jumava.

Außenministerium der Bundesrepublik Deutschland. Außen- und Europapolitik. Lettland.

Grundlinien der Außenpolitik. Pieejams: http://www.auswaertiges-amt.de/DE/Aussenpolitik/Laender/Laenderinfos/Lettland/Aussenpolitik_node.html (skatits 15.12.2016.)

Baltic States Nato candidacy gets political lift from Germany. Jamestown Foundation. Fortnightly Review. Vol. 8, 2002. February 15.

Cerūzis, R., 2015. Vācija uzvarētāju vēstures gūstā. Domuzìme, 2, 62-67.

Conze, E., 2009. Die Suche nach Sicherheit: eine Geschichte der Bundesrepublik Deutschland von 1949 bis in die Gegenwart. München: Siedler Verlag.

Dauchert, H., 2008. Deutschlands Baltikumpolitik Zwischen europäischer Integration und Annäherungen Russland. (Hrsg.) Henningsen, B., Nybom, T., Schröder, M. S., Wulff, R. NORDEUROPA forum18. 2. Berlin: Selbstverlagdes Herausgebers.

Feldmanis, I., Stranga, A., Taurēns, J., Zunda, A., 2016. Latvijas ārpolitika un diplomātija 20. gadsimtā. 1. sēj. Rīga: Jumava.

Feldmanis, I., 2005. Otrais pasaules karš: uztveres versijas un vērtējumi. Latvijas Kara muzeja gadagrāmata. VI. Rīga.

Hamm, R. M., 1992. Soviet Withdrawal from Germany. In Perspective. Boston University Open BU. Institute for the Study of Conflict, Ideology and Policy. Vol. II, No. 5. Pieejams: https://open.bu.edu/bitstream/handle/2144/3481/perspective_2_5_hamm. pdf? sequence $=1$ \&isAllowed $=$ y (skatìts 13.12 .2016 .)

Herold, E., 2005. Die Wiederaufnahme der diplomatischen Beziehungen zwischen Deutschland und Lettland im Jahre 1991. (Hrsg.) Anton, F., Luks, L., Krupnikov, P. Deutschland, Russland und das Baltikum: Beiträgezueiner Geschichtewechselvoller Beziehungen: Festschrift zum 85. Geburtstag von Peter Krupnikow. Köln.

Judt, T., 2005. Postwar: A History of Europe Since 1945. New York: Penguin Books.

Kenens, G. Vācieši uztver krievus kā kaimiņus. Latvijas Avizze, 04.01.2016. Pieejams: http:// www.la.lv/gerds-kenens-vaciesi-uztver-krievus-ka-kaiminus/ (skatīts 10.01.2016.)

Kohl, H., 2014. Helmut Kohl - Vom Mauerfall zur Wiedervereinigung: Meine Erinnerungen. München.

Kremp, H. Der Nato-Prozeß. Die Welt. 28.08.1995. Pieejams: https://www.welt.de/ print-welt/article661564/Der-Nato-Prozess.html (skatits 12.01.2017.)

Kuper, E., 1999. Die Osterweiterung von NATO und Europäischer Union: Ein Vergleich der Argumentationsmuster in Deutschland und in den USA. (Hrsg.) Dürr, T., Walter, F. Solidargemeinschaft und fragmentierte Gesellschaft: Parteien, Milieus und Verbände im Vergleich. Wiesbaden.

Lašas, A., 2010. European Union and NATO enlargement: Central and Eastern Europe. London: Palgrave Macmillan. 
Ministra pavēles par ārvalstu komandējumiem Nr. 1.-ārz.k. - Nr. 176.-ārz.k. 1. sēj. Latvijas Republikas Aizsardzibas ministrijas arhivs, 1. apr., 471. 1.

Readman, K. S., 2004. Germany and the Baltic Problem after the Cold War. The Development of a New Ostpolitik 1989-2000. London, New York: Routledge.

Rühle, M., 2000. Das neue Strategische Konzept der NATO und die politische Realität. Reiter (Hrsg.): Jahrbuch für internationale Sicherheitspolitik 2000. Hamburg, Berlin, Bonn.

Taurēns, J., Feldmanis, I., 2016. Latvijas ārpolitika un diplomātija 20. gadsimtā. 3. sēj. Rìga: Jumava.

Vācijas Federatīvās Republikas ārlietu ministra personiskā nota un Latvijas Republikas ārlietu ministra personiskā nota par diplomātisko attiecību atjaunošanu no 28.08.1991. Pieejams: http://www.mfa.gov.lv/images/archive/data/Izstades/atkalatzisana/087Vacija_d.JPG (skatīts 19.12.2016.). Pārējie līgumi ir pieejami šādās vietnēs:

Latvijas Republikas Ārlietu ministrija. Gadagrāmata 2001. IV. Hronologijia. Pieejams: http://www.mfa.gov.lv/ministrija/publikacijas/gadagramata-2001/saturs/ivhronologija (skatits 03.01.2017.)

Latvijas Republikas valdības un Vācijas Federatīvās Republikas valdības vienošanās par Vācijas Federatīvās Republikas valdības kompensācijām nacionālsociālistiskajā režīmā cietušajām personām Latvijā. Pieejams: http://likumi.lv/ta/lv/starptautiskieligumi/id/783-latvijas-republikas-valdibas-un-va cijas-federativas-republikas-valdibasvienosanas-par-vacijas-federativasrepublikas-valdibas (skatīts 19.12.2016.)

Līgums starp Latvijas Republikas valdību un Vācijas Federatīvās Republikas valdību par karā kritušo personu apbedījumiem. Pieejams: http://likumi.lv/ta/lv/ starptautiskie-ligumi/id/791-ligums-starp-latvijas-republikas-valdibu-un-vacijasfederativas republikas-valdibu-par-kara-krituso-personu-ap-bedijumiem (skatîts 12.10.2016.)

Nolīgums starp Latvijas Republikas valdību un Vācijas Federatīvās Republikas valdību par vācu skolotāju nosūtǐšanu uz Latvijas skolām. Pieejams: http://likumi.lv/ ta/lv/starptautiskie-ligumi/id/797-noli gums-starp-latvijas-republikas-valdibu-unvacijas-federativas-republikas-valdibu-ligumu-par-vacu-skolotajunosutisanu (skatīts 19.12.2016.)

Vanherpen, H. M., 2015. Putin's Propaganda Machine: Soft Power and Russian Foreign Policy. New York, London: Rowman \& Littlefield.

\section{ATSAUCES UN PIEZĪMES}

${ }^{1}$ Par tā saucamo "Uzvarētāju versiju" sīkāk var lasīt: Feldmanis, I., 2005. Otrais pasaules karš: uztveres versijas un vērtējumi. Latvijas Kara muzeja gadagrāmata. VI. Rīga, 11-17.

${ }^{2}$ Par spīti tam, ka politiski apvienošanās ar Austrumvāciju norisinājās samērā ātri un veiksmīgi, iekšpolitiski šis process turpinās vēl mūsdienās. Rietumvācieši bija spiesti maksāt par Austrumvācijas ekonomisko atpalicību ar ievērojamām finansiālās palīdzības programmām, cenšoties attīstīt infrastruktūru, lai mazinātu bezdarbu un masveida austrumvāciešu izcelıšanu. Austrumvācijas integrēšana bija milzīgs ekonomisks slogs Vācijas valdībai līdz pat 2000. gadam. Vēlāk Austrumvācijas attīstībā bija vērojamas pozitīvas attīstības tendences, lai gan pilnīgai komunistiskā mantojuma pārvarēšanai bijušajā Austrumvācijā būs nepieciešami vēl vairāki gadi. Plašāk: Rasnacis, V. Lēni, sāpīgi, taču veiksmīgi. 3. oktobris - Vācijas apvienošanās gadadiena. Latvijas Avize, 03.10.2016., 7. 


\title{
THE ROLE OF GERMANY IN LATVIA'S ACCESSION TO NATO (1991-2004)
}

\author{
VIESTURS RASNACIS \\ MA in History, historian at Latvian War Museum \\ E-mail: viesturs.rasnacis@gmail.com
}

\begin{abstract}
After the collapse of the Union of Soviet Socialist Republics (USSR), statesmen of Europe were sure that the Eastern European states, which had just regained their independence, would need a new security system. The Baltic States had no illusions about the Russian Federation's support, so they did not sign the Belavezha Accords and did not join the Commonwealth of Independent States (CIS), but turned to the Western allies instead, hoping to become members of NATO (North Atlantic Treaty Organization). A major support to the Republic of Latvia came from the Federal Republic of Germany, which presented itself as the advocate of Baltic interests in Western Europe. The admission of Latvia as a member state of NATO turned out to be a long and complicated process, which was made more complex by various political, social and economic aspects. Different groups of German society held different, even contrary attitudes to the issue of Latvia's accession to NATO, but it was Germany who played a very important and possibly even the key role in the positive outcome of this process.
\end{abstract}

Keywords: Latvia, Germany, NATO, contemporary history, international relations

\section{SUMMARY}

In the early 1990s it was clear that with the collapse of USSR the Eastern European countries would need a new security system. For the Baltic States the choice was quite obvious - they were looking towards integration into the Western defensive block with the long-term goal of NATO membership. In order to achieve this goal, they were looking for guidance and support from their Western allies, especially Germany, which had a historical obligation to help the less fortunate Baltic peoples (a belief shared by many Germans). After the restoration of diplomatic relations on $28^{\text {th }}$ August 1991, Germany provided economic, political and cultural support to Latvia that definitely had a good impact on the overall situation in the country. But considering its own interests and the international situation, Germany was careful to not provoke its Western neighbors and Russia. 
In addition, it was no easy task for the Baltic States to convince their Western allies of the necessity of their NATO membership. The Germans, who were the main advocates of the Baltic nations in Europe, were reluctant to supply them with offensive equipment mostly delivering them defensive armour and weapons suitable only for guarding their borders. This reluctance can partly be explained by the upsurge of the German-Russian relations and was further supported by the German business interests in Russia. In addition, there was also the obstacle of the Latvians not fulfilling their NATO candidacy obligations, not even within their limited capacities. Partially it can be explained by the high level of corruption in the government ministries.

In the late 1990s and early 2000s the political support of Germany for the Baltic States' NATO membership was much more outright. In contrast to the usually reserved official rhetoric on the part of the German officials, Germany actively participated in the economic and cultural restoration of Latvia investing heavily in the country and at the same time expanding its military support through several training courses and officer schools.

Despite the domestic and foreign policy difficulties, with the political and economic support from Germany, Latvia became a full-fledged member of NATO on $29^{\text {th }}$ of March 2004. While the Germans were a little more cautious towards the Baltic States than the Americans, which at the end of the millennium became more assertive regarding an eventual Baltic NATO membership, the influence of Germany's finances and counseling should not be underestimated. 


\title{
DIENESTS NEIEJAUKŠANĀS KOMITEJĀ SPĀNIJAS PILSOṆU KARA LIETĀS: LATVIJAS PILSOṆU ZIṆOJUMI
}

\author{
GINTA IEVA BIKŠE \\ Mg. hist. \\ E-pasts: ginta.ieva@hotmail.com
}

\begin{abstract}
ANOTĀCIJA
Vēloties palikt neitrālai Spānijas pilsoṇu karā, Latvija iesaistījās Londonā izveidotajā Neiejaukšanās komitejā. Tās dienestā, nodrošinot sauszemes robežu un jūras kontroli, strādāja 12 Latvijas pilsoṇi. Rakstā apskatīti Latvijas Nacionālā arhīva Latvijas Valsts vēstures arhīvā pieejamie piecu Latvijas pilsoṇu ziṇojumi par dienestu Neiejaukšanās komitejā. Detalizētāk analizēta ziṇojumos sniegtā informācija par ikdienā paveikto, situāciju Spānijā, kā arī sniegtās liecības par dienesta specifiku un kontroles efektivitāti. Atslēgas vārdi: ārpolitika, Spānijas pilsoṇu karš, Neiejaukšanās komiteja, latviešu virsnieki.
\end{abstract}

\section{IEVADS}

Pēc valsts apvērsuma īstenošanas mēgeinājuma 1936. gada 17. jūlijā Spānijas pilsoṇi sadalījās divās karojošās pusēs - viena puse cīnījās par nacionālistiskiem ideāliem (turpmāk - nacionālisti), bet otra - ne tikai par republikāniskām un sociālisma idejām, bet arī komunistiskiem, anarhistiskiem ideāliem (turpmāk - republikāṇi). Nevēloties iesaistīties Spānijas pilsoṇu karā, 1936. gada augustā 26 Eiropas valstis, ieskaitot Latviju, pievienojās Francijas 8. augusta notai par neitralitāti šajā konfliktā (Esch 1951, 57; Alpert 1994, 60). Pirmā Neiejaukšanās komitejas (angliski Non-Intervention Committee) tikšanās notika 9. septembrī Londonā. Zìmīgi, ka Neiejaukšanās komitejas dalībvalstu vidū bija arī fašistiskā Itālija un nacistiskā Vācija, kuras jau no paša sākuma neievēroja neitralitāti, 
tādējādi motivējot PSRS 1936. gada oktobrī sākt atbalstīt republikāṇu pusi (Phillips \& Phillips 2010, 254). Neiejaukšanās komitejas darbība un loma Spānijas pilsoṇu karā kopumā jau ilgstoši pētīta (Esch 1951; Watters 1971; Alpert 1994; Preston 2007 u. c.), tomēr Latvijas iesaiste Neiejaukšanās komitejā līdz šim maz aplūkota - plašāka informācija pieejama populārzinātniskā rakstā "Latviešu virsnieku "delikātie uzdevumi"” (Sprūde 2007).

Neiejaukšanās komiteja, lai nodrošinātu ieroču un kara materiālu neievešanu un liegtu brīvprātīgo ārvalstnieku nokḷūšanu Spānijā, izstrādāja plānus Spānijas sauszemes robežu un kuğu kontrolei. Tās sauszemes un jūras kontroles dienestā kopumā iesaistījās 12 Latvijas pilsoṇi. Pirmie dienestu 1937. gada 1. aprīlī vēl pirms robežu kontroles plāna stāšanās spēkā naktī no 19. uz 20. aprīli uzsāka bijušais Ārlietu ministrijas Rietumu nodaḷas vadītājs Pauls Reinhards un komandkapteinis Teodors Meija (LNA LVVA, 2570-14-1247, 71. lp.), kuri ieņēma augstākas kategorijas amatus P. Reinhards kḷuva par administratora vietas izpildītāju (Deputy Administrator) sauszemes robežas kontrolē Arjēžas departamentā, bet T. Meija - par administratora vietas izpildītāju jūras kontroles stacijā Verdonas ostā ( Le Verdon-sur-mer) (LNA LVVA, 2574-4-6890, 55. 1p.). No 1937. gada aprīla līdz 1938. gada oktobrim Neiejaukšanās komitejas dienestam pievienojās kapteinis Jānis Mednis, kapteinis Pēteris Apkalns, kapteinis Arnolds K,īsis, kapteinis Edgars Kadašs, virsleitnants Volfgangs Cirke, pulkvežleitnants Jānis Rucelis, kapteinis Jāzeps Ozoliņ̌̌, administratīvais kapteinis Vilis Valkovskis, virsleitnants Viktors Znotiņš, virsleitnants Kārlis Kraulis (LNA LVVA, 2574-4-7200, 112. 1p.).

Savu pieredzi Neiejaukšanās komitejas dienestā atmiṇās raksturojis J. Ozoliņš, tās publicētas (Ozoliņš 1997, 120-151). Savukārt ar T. Meijas, P. Reinharda, E. Kadaša, V. Cirkes un A. Ķiša pieredzi iespējams iepazìties dienesta ziņojumos, kuru oriǵināli pieejami Latvijas Nacionālā arhīva Latvijas Valsts vēstures arhīva vairāku fondu lietās. Ziņojumu hronolog̣iskās robežas ietver visu Neiejaukšanās komitejas jūras un sauszemes kontroles pastāvēšanas laiku, tie rakstīti no 1937. gada 18. aprīḷa līdz 1939. gada 23. martam. Visbiežāk ziņojumus par pieredzi jūras kontroles dienestā rakstījis E. Kadašs, kamēr visplašākos ziņojumus sniedzis P. Reinhards. Ziņojumiem bijuši vairāki adresāti - ārlietu ministrs, Latvijas sūtņi ārvalstīs, Ārlietu ministrijas Rietumu nodaḷas vadītājs. Turklāt nereti Ārlietu ministrijā saņemto ziņojumu noraksti pārsūtīti Latvijas sūtņiem Francijā, Šveicē, ASV un Lielbritānijā, lai informētu par Latvijas pilsoṇu pieredzi un novērojumiem Neiejaukšanās komitejas dienestā. Analizējot ziņojumos iekḷauto informāciju, to iespējams strukturēt kā paveiktu darbību, novērojumu un darba apstākḷu raksturojumu, kā arī ziņojumu autoru viedokli par Neiejaukšanās komitejas darbību. 


\section{PAVEIKTO DARBĪBU UN NOVĒROJUMU IZKLĀSTS}

Visdetalizētākos ziṇojumus rakstījuši jūras kontroles dienesta virsnieki, atskaitoties, uz kāda kuǵa ostā uzkāpuši un ko kontrolējamais kuǵis vedis, piemēram, rūdu, mākslīgos mēslus, labību, bēgḷus u. c. (LNA LVVA, 2574-4-7201, 78. 1p.; LNA LVVA, 2574-4-7201, 3. 1p.; LNA LVVA, 2575-7-2265, 13. 1p.). Atsevišķos gadījumos latviešu virsnieki konstatējuši, ka uz kuǵiem vesta kontrabanda, un ziņojuši par to - T. Meija ar saviem padotajiem 1937. gada oktobrī Verdonas ostā uz kuǵa "Margaret Rose" atraduši sprāgstvielas un šauteņu patronas (LNA LVVA, 2574-4-6900, 29. 1p.), bet E. Kadašs 1938. gada aprīlī ziņojis par munīcijas kontrabandu uz kuğa "Stanbrook" (LNA LVVA, 2574-4-7201, 73.-76. 1p.). Abos gadijjumos latviešu virsnieki bijuši vīlušies, ka kontrabanda tāpat nonākusi republikāņu rokās, bet sods par tās vešanu bijis pārāk mazs (LNA LVVA, 2575-7-2450, 24. 1p.; LNA LVVA, 2574-4-7201, 69.-70. 1p.).

Jūras kontroles dienesta novērotāji uz kug̣a varēja uzkāpt ne tikai Spānijai tuvākajās Vidusjūras ostās, bet arī Portugālē, Francijas rietumu ostās, Lielbritānijas Doveras ostā, no kurām kontrolējamie kug̣i devušies gan uz republikāṇu, gan nacionālistu ostām. Tādējādi latviešu virsnieki varēja novērot abu karojošo pušu situāciju Spānijā vai iegūt informāciju no kuǵa apkalpes, kad bija aizliegts izkāpt ostā. Tā, piemēram, V. Cirke 1937. gada 10. jūlijā ziņojis, ka republikāṇu kontrolētajā Alikantē trūkusi maize, gaḷa un cukurs (LNA LVVA, 2574-4-6900, 62.-63. 1p.). Vairākkārtēja atgriešanās Spānijā l̦āvusi latviešu virsniekiem arī salīdzināt situāciju, piemēram, E. Kadašs 1938. gada 27. februārī ziņ,jis, ka Barselonā situācija esot pasliktinājusies pēdējos četros piecos mēnešos - veikali palikuši tukši, preces kḷuvušas dārgas un ostā daudzi trūkumcietēji lūguši ziedojumus (LNA LVVA, 2574-4-7201, 92.-93. lp.). Līdzīgi V. Cirke 1938. gada septembrī ziņojis, ka Barselonā ieviesta kartīšu sistēma un sācies gandrīz bads, turklāt "kuǵa laudis negulēja uz kuǵa, bet par dažām cigaretēm dzīvoja lepnās viesnīcās" (LNA LVVA, 2574-4-7201, 3.-4. 1p.). Savukārt nacionālistu Spānijā gan V. Cirke, gan E. Kadašs bija redzējuši vācu kuǵus, kā arī jutuši vācu ietekmi, bet V. Cirke ievērojis arī itāḷu šautenes (LNA LVVA, 2574-4-6900, 38.-39. lp.; LNA LVVA, 2574-4-7201, 92.-93. 1p.). Savdabīgu situāciju 1937. gadā V. Cirke novērojis starptautiskajā Tanžērā, kur plīvojuši abu pušu karogi un bijis viens skatlogs gan ar Josifa Stalina, gan Fransisko Franko portretu (LNA LVVA, 2574-4-6900, 38.-39. 1p.).

Tā kā kravas un pasažieru kug̣i nebija pasargāti no karojošo pušu uzbrukumiem, jūras kontroles dienests bija saistīts ar risku. 1938. gadā uz republikāṇu pusi doties kḷuva arvien bīstamāk - T. Meija saṇēmis no V. Znotiṇa vēstuli, kurā pausta neapmierinātība par to, ka viņam bijis liegts bombardēšanas laikā Spānijā nokāpt no kuğa un meklēt slēptuvi (LNA LVVA, 
2574-4-7200, 164. 1p. o. p.). Gan T. Meija, gan E. Kadašs kopš 1938. gada vasaras ziņojuši, ka briesmu un pieaugošās bombardēšanas dēḷ arvien vairāk citu tautību virsnieki nevēlējušies doties uz Spāniju (LNA LVVA, 2574-4-7201, 38. 1p.; LNA LVVA, 2574-4-7200, 164. lp. o. p.). Minētās situācijas dēḷ T. Meija atzinīgi novērtējis latviešu drosmi un neizvairīšanos no dienesta (LNA LVVA, 2575-7-2450, 24. 1p.).

Jau 1937. gada jūnijā T. Meija un P. Reinhards tika paaugstināti par administratoriem (LNA LVVA, 2574-4-6900, 76.-77. 1p.). P. Reinhards zin,ojis par sauszemes robežu kontroles izaicinājumiem - lai arī bijuši zināmi kontrabandistu ceḷi, tomēr pieķeršana esot bijusi grūta, turklāt nereti bijis sarežḡîti san,emt pietiekošu vietējā prefekta atbalstu (LNA LVVA, 293-3-33, 2. lp., 10.-14. lp.). Tā kā P. Reinharda kontrolētais departaments bijis salīdzinoši mierīgs, 1937. gada 27. maijā viņš ziņoja, ka pirms dažām dienām par vēlu uzzinājuši, ka kādi 20 ārzemnieki bija pārgājuši robežu, turklāt žandarmi, kuri nedrīkstējuši šaut uz robežpārkāpējiem, to uzzinājuši vēl vēlāk (LNA LVVA, 2574-4-6900, 89.-90. lp.).

\section{DIENESTA APSTĀKLUU RAKSTUROJUMS}

Neiejaukšanās komitejas dienesta specifika paredzēja ilgstošu uzturēšanos ārvalstīs, turklāt jūras kontroles dienestā strādājošie bieži atradās ceḷā, piemēram, 1937. gada 23. novembrī V. Cirke ziņoja, ka bija 61 dienu atradies uz kug̣a "Black-bird" (LNA LVVA, 2574-4-6900, 11. 1p.). Kā mīnusu šādiem darba apstākḷiem E. Kadašs norādījis, ka “[..] par to, kas notiek pārējā pasaulē, esmu pilnīgā nezin̄ā” (LNA LVVA, 295-1-312, 76. 1p.). Ilgstoši nebija arī iespējams nokāpt no kug̣a Spānijas ostās, tādēḷ virsnieki nereti par notiekošo Spānijā varējuši spriest tikai pēc redzētā ostā vai dzirdētajām baumām (LNA LVVA, 2574-4-6900, 62. lp.).

Darba slodze Latvijas pilson,iem Neiejaukšanās dienestā bijusi dažāda un atšḳīrusies no situācijas karā. Dienesta sākumā 1937. gada 23. aprīīi T. Meija ziņoja, ka darba bijis daudz, tādēḷ nācies strādāt arī naktīs, bet jau 1938. gada sākumā darba kḷuvis mazāk arī lielajās ostās (LNA LVVA, 2575-7-2265, 42. 1p.; LNA LVVA, 2574-4-7201, 100. lp.). P. Reinhards pirmajā dienesta mēnesī minējis, ka darba daudzums ḷāvis avīzes lasīt tikai ap plkst. 23.00 (LNA LVVA, 293-3-33, 6. 1p.). Savukārt E. Kadašs dienesta sākumā ilgstoši Palermo sauḷojies un atpūties, jo gandrīz mēnesi kopā ar V. Cirki gaidījis dokumentu saņemšanu un izbraukšanu ar pirmo kug̣i (LNA LVVA, 2574-4-6900, 85. lp.). E. Kadašs labprāt devies uz Spāniju arī, kad lielākā daḷa atteikusies, jo gribējis novērot apstākḷus Spānijā un pēc aptuveni mēnesi ilga darba kancelejā Palermo 1938. gada vasarā vēlējies intensīvāku darbu un pārmaiņas (LNA LVVA, 2574-4-7201, 36., 38. lp.). 
Neiejaukšanās komitejas vadība ņēmusi vērā sūdzības par nelabvēèigiem darba apstākḷiem, uz ko norāda T. Meijas zin,ojumi, ka virsniekiem 1937. gada vidū jau ieviestas piemaksas par uzturēšanos dārgākās ostās, kā arī 1938. gada vidū vairākās ostās aprēḳinātas piemaksas par katru dienu, kas tur aizvadīta (LNA LVVA, 2574-4-6900, 46. 1p. o. p.; LNA LVVA, 2574-4-7201, 41. 1p.). Jau 1937. gada novembrī Neiejaukšanās komitejas sekretārs piedāvājis T. Meijam iesniegt lūgumu pārcelt biroju uz Bordo, kur virsniekiem būtu labāki dzīves apstākḷi, bet pārcelšanu T. Meija lūdzis vien 1938. gada rudenī, saprotot, ka vēl vienu ziemu virsniekiem Verdonā būtu grūti izturēt, jo tikai vienā viesnīcā bijusi pieejama apkure (LNA LVVA, 2574-4-6900, 30. 1p.; LNA LVVA, 2574-4-7201, 34., 41. 1p.).

Vienlaikus latviešu virsnieku ziņojumos pieejama informācija par nepiemērotām Neiejaukšanās komitejas dienesta amatpersonām. T. Meija minējis, ka no finanšu direktora saņēmis skaidrojumu, ka kandidāti izvēlēti l,oti steidzīgi, tādēḷ T. Meijam nācās saskarties ar darbinieku, kas nebija piemērots amatam un veicinājis nesaskaņas (LNA LVVA, 2574-4-6900, 48. lp. o. p.). Problēmas T. Meijam radījuši arī virsnieki, kuri par daudz lietojuši alkoholu, tādējādi atstājot sliktu iespaidu Verdonā, kurā daudzi iedzīvotāji atbalstījuši komunistiskas idejas un jau izrādījuši nepatiku pret Neiejaukšanās komiteju (LNA LVVA, 2574-4-7201, 41. 1p.).

\section{VĒRTĒJUMS PAR NEIEJAUKŠANĀS KOMITEJAS DARBĪBU}

Jau dienesta sākumā E. Kadašs bija dzirdējis par dažādām baumām, kas bija saistītas ar Neiejaukšanās komiteju, tādēl piel̦āva, ka sauszemes robežu un jūras kontrole varētu neizdoties, piebilstot, ka "baidos izteikties par stipru, bet vismaz citi smejas, ka visa šī neiejaukšanās būšana ir tikai - farss" (LNA LVVA, 2574-4-6900, 46. lp.). Par sauszemes robežas un jūras kontroles neefektivitāti un nevienlīdzību abām pusēm, it īpaši sastādot brīvprātīgo atsaukšanas plānu, P. Reinhards 1938. gada 27. maijā ārlietu ministram Vilhelmam Munteram ziņojis, norādot, ka ieroču kontrabanda nekad nav apstājusies un ka pat tie, kuri vēlētos pilnībā ierobežot ārvalstu palīdzību Spānijai, “[..] klusībā nodomā, ka pie šīs sistēmas pieturoties Franko pusei tomēr būs vieglāk gūt palīdzību no ārienes, ja apstākḷi uz to spiedīs, nekā Madridei - kauču arī tikai attāluma pēc un zemūdenuu darbības dēḷ" (LNA LVVA, 2575-7-2450, 36., 38. lp.). Turklāt, lasot ziņas avīzēs, P. Reinhards bija guvis iespaidu, ka neiejaukšanās "[..] sāk palikt par modes lietu, - arī uz Čehoslovākiju tādu gribot sūtīt. Baidos, ka tā nav prelūdija lielgabalu koncertam" (LNA LVVA, 2575-7-2450, 39. 1p.).

Arī ikdienas darbā latviešu virsnieki saskārās ar Neiejaukšanās komitejas trūkumiem un nespēju pildīt savus izvirzītos mērḳus. Ilgāk esot 
dienestā, E. Kadašs izrādīja neapmierinātību par atsevišķu dienesta amatpersonu izvēli, jo vinš̌ bija sastapis daudzus dzērājus, kā arī pat bijušos kontrabandistus, tādēl sašutis, ka "[..] valstis neskatās, ko šim amatam sūtīt" (LNA LVVA, 295-1-312, 324. 1p.). Savukārt V. Cirke 1939. gada sākumā ziņoja, ka san,ēmis Neiejaukšanās komitejas rīkojumu, kas paredzējis, ka uz republikān,u kontrolēto Spāniju vairs nebija jābrauc ne tikai jau iepriekš paredzētajam izṇēmumam - portugāḷiem, bet arī vāciešiem un itāliešiem, kas nozīmēja, ka turpmāk visu trīs tautību pārstāvji nacionālistu pusē kontrolēs "pašas sevi" (LNA LVVA, 2574-4-7523, 62. 1p.).

Jau pēc trīs dienestā pavadītiem mēnešiem P. Reinhards saskatīja nepieciešamus uzlabojumus sauszemes robežu kontroles nodrošināšanā, tādēl plašā ziņojumā sniedza izvērtējumu par sistēmas priekšrocībām un trūkumiem. P. Reinhards ziņojumā paudis, ka kontrolieru skaits bijis pietiekams, taču būtu nepieciešams pieņemt labāk kvalificētus darbiniekus, kā arī būtiskāk būtu ieviest iespēju stingrāk kontrolēt, nevis tikai novērot pārkāpumus. Turklāt būtu jāpārbauda katrs vilciens pirms piestāšanas stacijā, visi robežu šķērsojošie cilvēki, mašīnas un jāievieš lieguma zona trīs līdz piecus kilometrus pirms robežas (LNA LVVA, 2574-4-6900, 15.-26. 1p.).

\section{SECINĀJUMI}

Neiejaukšanās komitejas jūras kontroles dienestā iesaistīto latviešu zin,ojumi bijuši l, loti detalizēti - daudzi no tiem l,auj izsekot virsnieku maršrutiem, kā arī sniedz plašu ieskatu kravās, kuras bija nepieciešams kontrolēt un pavadīt uz Spāniju. Tajā pašā laikā jūras kontrolē iesaistīto Latvijas pilsoṇu darbs bija visvairāk saistīts ar kara draudiem un grūtībām. Tomēr ne E. Kadaša, ne A. Ķǐša vai V. Cirkes ziņojumos neizskan vēlme izvairīties no briesmām. Tieši pretēji - T. Meija, saskaroties ar citu tautību virsnieku atteikšanos doties uz Spāniju, uzslavējis latviešu drosmi.

Biežā došanās uz Spāniju l̦āva Latvijas pilsoṇiem sniegt Latvijas ārpolitikas veidotājiem noderīgu informāciju un novērojumus par situāciju Spānijā. Virsnieku ziṇojumos nereti salīdzināti apstāḳ̣i Spānijā dažādos laika posmos, norādot uz situācijas pakāpenisku pasliktināšanos republikāṇu pusē. Ziņojumos pieejama informācija arī par ikdienas apstākḷiem, slodzi, kas bieži vien nav bijusi samērīga. Tāpat novērotāji ziņojuši, ja saskārušies ar ieroču un munīcijas kontrabandu, kā arī brīvprātīgajiem, kas nelegāli šḳērsojuši robežu.

Vienlaikus Latvijas pilsoṇu pieredze norādījusi uz Neiejaukšanās komitejas nespēju pilnībā izpildīt tās mērḳus. E. Kadašs, T. Meija un P. Reinhards ziņojumos snieguši informāciju par novēroto kontrabandu vai ārzemju brīvprātīgo došanos uz Spāniju un pauduši nožēlu, ka Neiejaukšanās komiteja 
nav nodrošinājusi pietiekamu sodu vai uzlabojusi situāciju, lai nākotnē netiktu veikti pārkāpumi. Latviešu virsnieki saskārušies arī ar kolēg̣iem, kas nav bijuši piemēroti dienestam un grāvuši Neiejaukšanās komitejas reputāciju. Turklāt nereti iegūta informācija, kas pierādījusi Neiejaukšanās komitejas sauszemes robežu un jūras kontroles neefektivitāti.

\section{IZMANTOTIE AVOTI UN LITERATŪRA}

\section{AVOTI}

Arnolda Kīša ziṇojums, 06.11.1937. Latvijas Nacionālais arhīvs - Latvijas Valsts vēstures arhivs (Rīga, turpmāk: LNA LVVA), 13.-14. lp.

Edgara Kadaša ziṇojums Ārlietu ministrijas Rietumu nodal̦as vadītājam Vilim Masēnam, 21.03.1938. LNA LVVA, 2574-4-7201, 78.-79. lp. o. p.

E. Kadaša ziņojums Latvijas sūtnim Itālijā Arnoldam Spekkem, 27.02.1938. LNA LVVA, 2574-4-7201, 92.-93. lp. o. p.

E. Kadaša ziņojums A. Spekkem, 22.06.1937. LNA LVVA, 2574-4-6900, 85.-85. 1p. o. p.

E. Kadaša ziṇojums A. Spekkem, 08.06.1938. LNA LVVA, 2574-4-7201, 38.-38. 1p. o. p.

E. Kadaša ziņojums A. Spekkem, 21.06.1938. LNA LVVA, 2574-4-7201, 36.-36. 1p. o. p.

E. Kadaša ziņojums V. Masēnam, 11.04.1938. LNA LVVA, 2574-4-7201, 73.-76. 1p. o. p.

E. Kadaša ziņojums V. Masēnam. 1938. LNA LVVA, 2574-4-7201, 69.-70. lp. o. p.

E. Kadaša ziņojums V. Masēnam, 11.04.1938. LNA LVVA, 295-1-312, 76. -79. 1p.

E. Kadaša ziṇojums Latvijas sūtnim Londonā Kārlim Zariṇam, 23.10.1938. LNA LVVA, 295-1-312, 323.-324. lp. o. p.

Latvijas pilsoṇi Spānijas kontroles dienestā. LNA LVVA, 2574-4-7200, 112. lp.

K. Zariņa raksts Latvijas ārlietu ministram Vilhelmam Munteram, 17.03.1937. LNA LVVA, 2574-4-6890, 55. lp.

K. Zarina raksts V. Munteram, 15.07.1937. LNA LVVA, 2574-4-6900, 76.-77. lp.

Neiejaukšanās komitejas sekretāra Frānsisa Heminga raksts K. Zarinamam [angḷu val.], 24.03.1937. LNA LVVA, 2570-14-1247, 71. lp.

Ozoliņš, J., 1997. Virsdzive: virsnieka atmiņas. Valmiera.

Paula Reinharda ziņojums V. Munteram, 23.04.1937. LNA LVVA, 293-3-33, 2.-7. 1p.

P. Reinharda ziņojums V. Munteram, 27.05.1937. LNA LVVA, 2574-4-6900, 89.-90. lp.

P. Reinharda ziņojums V. Munteram, 26.06.1937. LNA LVVA, 293-3-33, 10.-16. lp.

P. Reinharda ziņojums [franču val.], 27.11.1937. LNA LVVA, 2574-4-6900, 15.-26. lp.

P. Reinharda ziņojums V. Munteram, 27.05.1938. LNA LVVA, 2575-7-2450, 36.-39. lp.

Teodora Meijas ziņojums V. Munteram, 19.11.1937. LNA LVVA, 2574-4-6900, 29.-30. lp.

T. Meijas ziñojums V. Munteram, 23.04.1937. LNA LVVA, 2575-7-2265, 42.-42. 1p. o. p.

T. Meijas ziņojums V. Munteram, 26.08.1937. LNA LVVA, 2574-4-6900, 48.-48. 1p. o. p.

T. Meijas zinojums V. Munteram, 13.09.1937. LNA LVVA, 2574-4-6900, 46.-46. 1p. o. p.

T. Meijas zinojums V. Munteram, 19.11.1937. LNA LVVA, 2574-4-6900, 29.-30. lp.

T. Meijas ziņojums V. Munteram, 15.12.1937. LNA LVVA, 2575-7-2450, 24. lp.

T. Meijas ziņojums V. Munteram, 08.02.1938. LNA LVVA, 2574-4-7201, 99.-100. lp.

T. Meijas ziņojums, 24.05.1938. LNA LVVA, 2574-4-7201, 34. lp. 
T. Meijas zinojums, 21.07.1938. LNA LVVA, 2574-4-7201, 41. lp.

T. Meijas ziņojums V. Munteram, 06.10.1938. LNA LVVA, 2574-4-7200, 164.-164. 1p. o. p. Volfganga Cirkes ziņojums, 06.09.1938. LNA LVVA, 2574-4-7201, 3.-4. lp.

V. Cirkes ziņojums V. Masēnam, 10.07.1937. LNA LVVA, 2574-4-6900, 62.-63. 1p. o. p.

V. Cirkes zinojums, 30.10.1937. LNA LVVA, 2574-4-6900, 38.-39. lp.

V. Cirkes ziņojums, 23.11.1937. LNA LVVA, 2574-4-6900, 11.-12. lp.

V. Cirkes zinojums, 24.01.1939. LNA LVVA, 2574-4-7523, 62.-63. lp.

\section{LITERATŪRA}

Alpert, M. A., 1994. A New International History of the Spanish Civil War. Palgrave Macmillan.

Esch, P. A. M., 1951. Prelude to War: The International Repercussions of the Spanish Civil War (1936-1939). Pieejams: https://books.google.lv (skatits 05.01.2018.)

Phillips, C. R., Phillips, W. D. A., 2010. A concise history of Spain. New York: Cambridge University Press.

Preston, P., 2007. The Spanish Civil War: Reaction, Revolution, and Revenge (Revised and Expanded Edition). W. W. Norton \& Company.

Sprūde, V., 2007. Latviešu virsnieku “delikātie uzdevumi”. Pieejams: http://www.tvnet.lv/ apollo/celojumi/695472-latviesu_virsnieku_delikatie_uzdevumi (skatìts 10.01.2018.)

Watters, W. E., 1971. An international affair: non-intervention in the Spanish Civil War, 1936-1939. New York: Exposition Press. 


\title{
REPORTS BY LATVIAN CITIZENS ON THEIR SERVICE IN THE NON-INTERVENTION COMMITTEE
}

\section{GINTA IEVA BIKŠE}

BA in History

Email: ginta.ieva@hotmail.com

\begin{abstract}
Latvia adhered to the principle of non-intervention vis-a-vis the Spanish Civil War and participated in the Non-Intervention Committee founded in London. 12 Latvian citizens were actively involved in the Non-Intervention Committee's land and sea observation scheme. The main sources of the paper are documents from the State History Archives under the National Archives of Latvia that contain reports written by five Latvian citizens who participated in the scheme. This paper examines the information provided in the reports, analysing the Latvian citizens' description of their everyday work and the situation in Spain, as well as the specifics of their service and the effectiveness of the Non-Intervention Committee.
\end{abstract}

Keywords: foreign policy, Spanish Civil War, Non-Intervention Committee, Latvian officers.

\section{SUMMARY}

The article examines the experience of Teodors Meija, Pauls Reinhards, Edgars Kadašs, Volfgangs Cirke and Arnolds Kīsis in the Non-Intervention Committee's land and sea observation scheme. Their reports are available at the State History Archives under the National Archives of Latvia. The reports were addressed to the Minister of Foreign Affairs, Latvian Ambassadors and the Head of the Western Division at the Ministry of Foreign Affairs.

Latvians involved in the sea observation scheme sent the most detailed reports. Their work was dangerous as they had to go to Spain during the Spanish Civil War. Frequent visits to Spain allowed Latvian citizens to provide Latvia's foreign policy makers with useful information and observations on the situation in Spain. Officers' reports often compared 
the situation in different time periods, indicating a deterioration of the situation on the Republican side.

Latvian officers also came across weapon and ammunition smugglers as well as volunteers who illegally crossed the border. The experience described by the Latvian observers allows us to see that the NonInterference Committee did not meet its objectives. The Latvian citizens were not satisfied with the light sentences for violations and in some of their reports stressed the inadequate selection of other observers. 


\title{
HOLOKAUSTS VARAKḶĀNU UN TĀS APKĀRTNES IEDZĪVOTĀJU KOMUNIKATĪVAJĀ ATMIṆĀ
}

\author{
KASPARS STRODS \\ Mg. arhiu., Rēzeknes Tehnoloğiju akadēmija, Latgales Kultūrvēstures muzejs \\ E-pasts: kaspars.strods88@inbox.lu
}

\begin{abstract}
ANOTĀCIJA
Raksta mērḳis ir apkopot un analizēt atmiṇas par holokausta notikumiem Varakḷānos, kuras saglabājušās vietējo iedzīvotāju mutvārdu intervijās, kā arī rakstiskajos avotos. Pētījuma pamatā izmantotas vairākas mutvārdu vēstures intervijas ar Varakḷānu un tuvākās apkārtnes iedzīvotājiem. Tās kontekstā ar citiem materiāliem lauj labāk izprast attiecīgo notikumu norisi un vietējo iedzīvotāju attieksmi pret ebreju tautības pārstāvjiem konkrētajā vēstures situācijā.
\end{abstract}

Atslēgas vārdi: holokausts, komunikatīvā atmiṇa, ebreji, Varakḷāni.

\section{IEVADS}

Otrais pasaules karš un holokausts ir viena no visplašāk pētītajām tēmām Latvijas historiogrāfijā. Pēdējos gados aktuāli kḷuvuši pētījumi par holokausta norisi dažādās Latvijas pilsētās, kurās lielu daḷu no iedzīvotāju kopskaita veidoja ebreji (tostarp Latgales reǵionā). Viena no šādām pilsētām bija Varakḷāni, kurā, pēc 1935. gada tautas skaitǐšanas datiem, no 1661 pilsētas iedzīvotāja 952 jeb 57,32\% bija ebreji (Salnītis, Skujenieks 1936, 298). Šì skaitliski lielā Varakḷānu ebreju kopiena gandrīz pilnībā tika iznīcināta holokausta laikā. Ar holokaustu apzīmē ebreju masveida iznīcināšanu Otrā pasaules kara laikā. Vēsturnieks Jehuda Bauers (Yehuda Bauer) atzīmē, "[..] ka mūsdienās vārds holokausts Eiropā asociējas ar ebreju masu nogalināšanu nacistu režīma laikā, kurā tika iznīcināti aptuveni 5,8 milijoni ebreju" (Bauer 1978, 30). Savukārt ebreju tautības vēsturnieks 
Rauls Hilbergs (Raul Hilberg) izsaka viedokli, ka "holokausts bija [..] sistemātiska programma, kas tika īstenota soli pa solim, iznīcināšanai pakḷaujot piecus miljonus upuru" (Hilberg 2003), tādējādi norādot uz holokausta mērḳtiecīgo īstenošanu un tā upuru milzìgo apmēru.

Iepriekš minētie notikumi palikuši vairāku Varaḳ̣ānu iedzīvotāju atmiņās, un tajos atklājas ebreju tautības pārstāvju trağiskais liktenis. Kā skaidro Baiba Bela-Krūminna, "tad dzīvesstāsts stāsta ne tikai par pagātnes notikumiem un cilvēka individuālo dzīves pieredzi, bet tie palīdz izprast cilvēka dzīves nozīmi, kā arī sabiedrību un kultūru, kurā mēs dzīvojam" (Bela-Krūmina 2001, 75). Šajās intervijās atklājas dažādās ebreju rakstura īpašības un konkrēta rīcība šo vēsturisko notikumu kontekstā.

Pētījuma gaitā tika intervēti astoṇi respondenti, kuri dzimuši laika posmā no 1924. līdz 1939. gadam un savā dzīves laikā ir vai nu bijuši liecinieki, vai ir dzirdējuši par Otrā pasaules kara holokausta notikumiem Varakḷānos. Izjautājot respondentus, tika izmantota strukturētās intervijas metode, jo tā laauj rekonstruēt kādu vēsturisku notikumu, kā arī atklāj cilvēka personīgo pieredzi un attieksmi pret konkrētiem notikumiem. Tomēr kā negatīvais aspekts jāmin, ka, atškirīīā no dzīvesstāsta, strukturētā intervija savā ziņā ierobežo respondentu, tāpēc maza uzmanība tiek pievērsta cilvēka dzīves uzskatiem, vērtībām u. c. aspektiem.

Sociālā atmiņa ir viens no vairākiem jēdzieniem (kolektīvā atmiņa, vēsturiskā atmiņa, kultūras atmiņa, komunikatīvā atmiṇa u. c.), kas tiek saistīts ar konkrētas sabiedrības grupas skatījumu uz pagātnes notikumiem (Bērzin̦š 2015, 17). Iepriekš minētais jēdziens "ir selektīvs, subjektīvs un mainīgs priekšstats par pagātni, ko veido gan faktu zināšanas un pieredze, gan iztēle un refleksija" (Bērziņš 2015, 49). Aptaujāto respondentu stāstos vairāk dominē individuālā jeb komunikatīvā atmiṇa. Ar jēdzienu "komunikatīvā atmiṇa" "[..] saprotamas nozīmes, kas tiek nodotas starp paaudzēm (tipiski - vecvecāki nodod mazbērniem) starppersonu ikdienas komunikācijas formā un līdz ar to pakḷautas lielākai mainībai un pārveidojamas" (Bērziņš 2015, 43). Šãda informācijas iegūšana raksturīga arī dažiem pētījumā intervētajiem cilvēkiem, kuri to ieguvuši no saviem tuviniekiem (tēviem vai mātēm). Būtisks komunikatīvās atmiņas raksturojošs elements ir cilvēka mūža ilgums, līdz ar to, lai indivīda atmiņa nepazustu, tai jātransformējas un jāpieņem kāda no kultūras atmiņas formām (tēli, rituāli u. c.) (Bērziņš 2015, 43-44).

\section{MASU SLEPKAVĪBA EBREJU KAPOS}

Viena no centrālajām vietām Varakḷānos, kas saistās ar holokaustu, ir vietējā ebreju kapsēta. Vairākos respondentu stāstijumos rodama informācija par notikumiem konkrētajā vietā. Piemēram, S. G. ${ }^{1}$ atceras dienu, kad 
viņš, meklējot savu tēvu, "kuram bijis jādodas pēc rīkojuma uz nezināmu vietu ar lāpstu", ejot garām Varakḷānu ebreju kapiem, "redzējis lielu skaitu ebreju un brunotos vīrus ap tiem apkārt". S. G. atzīmē, ka starp bruṇotajiem viņš "pamanījis kādu paziņu no Saikavas. Taču pēc tēva atrašanas un viņa ieteikuma ātri devies prom" (S. G. 2014). Teicējs gan neprecizēja šī notikuma dienu, tomēr, salīdzinot ar vēstures literatūru un citām intervijām, konstatēts, ka stāstīts ir par 1941. gada 4. augustu, kad Varakḷānos pie ebreju kapu robežas tika nogalināti vairāk nekā 500 ebreju (Ročko 2008, 209).

S. G., stāstot par šajā dienā pieredzēto, sīki apraksta, kas notika ar ebrejiem, kuri bija atvesti uz ebreju kapiem. Viņš norāda uz vairākām ebrejus pazemojošām darbībām: "grūšanu laukā no mašīnas, pēc kuras tiem nācās gulties uz zemes; nog̣ērbšanos, ko nācās veikt grupās pa desmit; drēbju sakārtošanu un došanos pie dobes" (S. G. 2014). Stāstot par šāvēju skaitu, viņš norāda, ka to "bijis 20", un akcentē, ka "[..] pirms šaušanas katrs no šāvējiem lietoja alkoholu, lai uzturētu sevi kondīcijā" (S. G. 2014). Acīmredzot alkohols ir lietots, lai mazinātu spriedzi un pārvarētu psiholog̣iskās bailes. S. G. intervijā atspoguḷota arī šaušanas secība, pēc stāstītā var secināt, ka "upuriem šauts mugurā un pakausī" (S. G. 2014). Konkrēto informāciju respondentam pastāstījis viṇa tēvs, kurš bija norīkots bedru rakšanas un vēlāk arī aizrakšanas darbos (S. G. 2014). Intervējamā iepriekš minētie fakti sakrīt ar Grigorija Smirina aprakstìto Rīgas ebreju nogalināšanas sistēmu Biḳernieku mežā, kur ebreju iznīcināšanā parasti piedalījās Arāja komandas ${ }^{2}$ dalībnieki. G. Smirins raksta, ka parasti bijuši 20 šāvēji uz 10 upuriem, no kuriem "viens tēmējis mugurā, savukārt otrs - galvā". Tāpat G. Smirins norāda, ka pēc šaušanas vai arī tās laikā parasti notikusi šāvēju cienāšana ar degvīnu (Smirins 2006, 89). Arāja komandas klātbūtni Varakḷānu ebreju iznīcināšanas akcijā netieši apstiprina arī B. S., kura atceras, ka "[..] uz ebreju šaušanu esot atvesti latviešu tautības pārstāvji no Kurzemes, kuri bijuši l,oti pacilāti un pirms ebreju iznīcināšanas dziedājuši "priecīgas (antisemìtiska satura - aut. piezīme) dziesmas" (B. S. 2015). Arī Josifs Ročko piemin "zilo autobusu"3 klātesamību Varakḷānu ebreju nošaušanas laikā (Ročko 2008, 212), tādējādi apstiprinot, ka Varakḷānu ebreju iznīcināšanā piedalījās Arāja komanda, kas savās izbraukuma akcijās apmeklēja tādas pilsētas kā Bauska, Krustpils, Jēkabpils, Viḷāni, Rēzekne u. c. (Ezergailis 1999, 221). Vēsturnieks Andrievs Ezergailis uzsver, ka ne visus ebrejus iznīcināja Arāja komanda, nereti šîs slepkavībās paveica "vietējās noorganizētās" šāvēju vienības (Egle 2013, 32). Tam piekrīt vēsturniece Rudìte Vikksne, pamatojot, ka nacistu taktika bija "attālināt pašus vāciešus no šì lielā nozieguma”, uz ko norādot Nacionālsociālistiskās partijas Ārpolitikas pārvaldē notikusī sēde, kurā tikusi "apspriesta vadlīnija "ebreju jautājuma nokārtošanā”"'. Sēdes protokoli liecina, ka ebreju iznīcināšanā bija 
jāiesaista vietējie iedzīvotāji, "atbrīvojot tiem brīvas rokas" (Vīksne 2004, 42). Taču ne ebreju, ne latviešu atmin,as par šiem traǵiskajiem notikumiem nevar vērtēt viennozīmīgi.

\section{VIETÉJO IEDZĪVOTĀJU LĪDZDALĪBA}

Varakḷāniešu atmiṇās ir saglabājušās liecības arī par latviešu tautības pārstāvju līdzdalību holokaustā. Piemēram, S. G. pieminētais "šucmanis"4 no Saikavas nav vienīgais varakḷāniešu atmiṇās pieminētais latviešu tautības holokausta līdzdalībnieks. Stāstot par Varakḷānu ebreju likteni, S. G. atzīmēja, ka pēc ebreju sadzī̌̌anas patērētāju biedrības veikala pagalmā viņus apsargāja vairāki viņa klasesbiedri (S. G. 2015). Savukārt A. S. atceras, "ka vietējie iedzīvotāji esot runājuši par kādu vīrieti ar uzvārdu S., kurš lielījies, ka esot n,ēmis žīdus uz grauda". Šo faktu ticamāku padara šī S. māsas A. “"lielā” turība, kas tikusi skaidrota ar ebrejiem atņemtajām mantām, kuras atrastas viņas šḳūnī". Kā piemērs "tika minētas zelta un sudraba karotes" (A. S. 2014). Tāpat A. S. "piemin kādu K., kas esot bijis A. Š. tēva brālis un kas, iespējams, esot saistīts ar holokaustu, jo vin,am esot piederējusi kuḷmašīna. Vietējie esot runājuši, ka tā pirkta par nogalināto ebreju zeltu" (A. S. 2014). Šajās norādēs par vienu no holokausta cēloṇiem tiek minēta ebreju turība. To uzsver arī Josifs Ročko, rakstot, ka "ebrejiem pirms nošaušanas tika atņemtas visas vērtīgās mantas, kuras tiem bija pavēlēts n,emt līdzi" (Ročko 2008, 212). B. D. savās atmiņās pauž neizpratni par to, ka, evakuējoties no pilsētas, pa viņiem (viņas gimenes locekḷiem aut. piezīme) šāvuši "vietējie aizsargi, lai arī pilsētā vēl nebija ienākušas vācu armijas daḷas" (B. D. 2014). Konkrētajā gadījumā respondente netieši norāda uz t. s. interegnum jeb bezvaras laiku, kad īsi pirms nacistiskās Vācijas karaspēka ienākšanas Latvijas teritorijā vairākas apdzīvotās vietas bija atstājuši padomju okupācijas spēki. Vēsturnieks Aivars Stranga secina, ka iepriekš minētais laiks ir bijis pārāk īss, kurā vietējie iedzīvotāji nav veikuši ebreju sistemātisku iznīcināšanu, tomēr atsevišksos gadījumos pret ebrejiem tika vērsta pazemojoša attieksme un viṇu ìpašumi izlaupīti, tāda situācija bija novērojama, piemēram, Limbažos (Stranga 2004, 215).

V. B. atceras, ka Varakḷānos "kādas mājas pagalmā atradusies liela čupa ar nezināmām mantām” (V. B. 2014), kas, visticamāk, bija aț̣emtas nogalinātajiem ebrejiem. J. B. stāsta, ka esot dzirdējis runas par to, ka "pēc vācu armijas ienākšanas veidota vietējo iedzīvotāju banda, kuriem jāveic ebreju iznīcināšana" (J. B. 2014). Atsaucoties uz Andrievu Ezergaili, uz to norāda arī citi autori, rakstot, ka "[..] dažās pilsētās šāvēju grupas tikušas veidotas no vietējiem iedzivvotājiem, kas nereti esot lietojuši alkoholu" (Egle 2013, 32). Par alkohola lietošanu masu slepkavībās iesaistīto personu 
vidū izsakās viens no holokausta laikā izdzīvojušajiem ebrejiem, pazīstamais vēsturnieks Marğers Vestermanis: "Slepkavas pēc slepkavošanas akcijas brauca krietni iesiluši, jo vienmēr bija alkohols..." (Bērzinšs 2015, 492)

Tie bijuši atsevišksi gadījumi, un, kā liecina varaklāaniešu atmiṇas, vietējie iedzīvotāji nebija ieinteresēti iesaistīties ebreju iznīcināšanā un centās izvairīties no piespiedu cilvēku slepkavošanas. A. G. stāsta, ka "viņas tēvs noraidīja vācu pavēli doties šaut ebrejus un, baidoties no iespējamajām represijām, aizbēga un slēpās tuvējā mežā" (A. G. 2014), šādi apliecinot savu nostāju pret valdošo varu un tās īstenoto teroru pret ebrejiem. Arī J. Ročko norāda, ka "Varakḷānu iedzīvotāji pārsvarā pret ebrejiem izturējušies ar līdzjūtību un palīdzējuši tiem" (Ročko 2008, 210).

Savukārt A. Stranga uzsver: lai arī "ebreju slepkavošanu organizēja un vadīja vācieši, l,oti reti bija gadījumi, kad vietējie pašaizsardzības vai kādas citas vienības locekḷi atteicās vai izvairījās no piedalīšanās ebreju nogalināšanā" (Stranga 2008, 25). Tomēr arī citi Varakḷānu iedzīvotāji centušies palīizēt ebrejiem. Piemēram, Velta Bāliņa atceras, ka viṇas māte pēc vācu armijas ienākšanas devusi ebrejam Aizikam Goldbergam (bērnības draudzenes Gitas Goldbergas brālis) pienu, maizi, sieru (Bāliṇa 2002, 4). Vēlāk, kad viṇas tēvs aizvedis Aiziku uz Varakḷāniem un pilsētā Aiziku "saķēruši vietējie varas vīri, un pāris dienas vēlāk esot atskanējuši šāvieni no ebreju kapiem, viņi sapratuši, ka nav vairs ko gaidīt atpakal," (Bāliņa 2002, 4). Nereti tāpēc notikušas latviešu un ebreju savstarpējās laulības. V. B. stāsta par kādu Elstu, kurš “[..] apprecējies ar ebreju sievieti, kas pieṇēmusi kristīgo ticību, taču vēlāk vācieši viṇu tik un tā esot nošāvuši" (V. B. 2014). Līdzīgu informāciju sniedz arī Josifs Ročko, kurš darbā "Holokausts Latgalē" piemin "latvieša Pētera Elsta un ebrejietes Dobes Rivas Frīdas laulību" (Ročko 2008, 211). A. S. uzsver, ka "latvieši nosodījuši citu latviešu līdzdalību holokaustā" (A. S. 2014). No intervijām un vēstures literatūras var secināt, ka to darījuši pagrimuši cilvēki, kas nereti bija "labi dzērāji" (S. G. 2014).

Atsevišķos gadījumos ebreju slēpšanos atklājuši paši to slēpēji, iespējams, bailēs no vācu armijas represijām vai mantkārīgos nolūkos. Tādu gadījumu savās atmiṇās atceras arī S. G., stāstot, "ka Valdeniekos kāds saimnieks esot nodevis divus ebrejus, kurus vēlāk nošāva. Tas noticis apmēram mēnesi pēc ebreju masu iznīcināšanas pie ebreju kapiem" (S. G. 2014). Arīdzan holokausta laikā izdzīvojusī ebrejiete Frīda Mihelsone, aprakstot 1941. gada jūlija sākuma notikumus, norāda, ka nekāda "pretestība viņiem (vāciešiem - aut. piezīme) netiek izrādīta", bet tieši pretēji, vairāki "vietējie iedzīvoji laipni izrāda apkārtni un parāda, kur dzīvo ebreji" (Mihelsone 2014, 25). Tādējādi saskatāmas kolaborācijas pazīmes, kas bija raksturīgas vairākās nacistiskās Vācijas okupētajās teritorijās. 
B. D. atceras, ka pēc atgriešanās Varakḷānos vietējie latvieši esot stāstījuši, ka kāds Varakḷānu slimnīcā strādājošs īpaši nežēlīgs feldšeris esot nogalinājis kādai bagātai ebreju sievietei tikko piedzimušo bērnu. Jāmin fakts, ka, emocionāli raksturojot feldšera rīcību, respondente izmantoja apzīmējumu "tāds fašists" (B. D. 2014), tādējādi parādot savu krasi nosodošo attieksmi pret šādām necilvēciskām darbībām. Šeit konstatējama arī kolektīvajai atmiņai raksturīga iezīme: "lai iegūtu kolektīvo atmiņu, indivīdam nav jābūt piedzīvojušam konkrēto notikumu”, bet tam "ir jābūt l,oti nozīmīgam, lai tas tiek uztverts/izskatīts atmiņā, nevis vēsturiskajā skatījumā" (Hunt 2010, 97). Jāatzīst, ka daudzi ebreji sevi asociē ar holokausta notikumiem. Kā uzskata Helsinku Universitātes pētniece Anu Kantola (Anu Kantola), “atmiņas par holokaustu ebrejiem nodrošina pastāvīgu upura identitāti” (Kantola 2014, 95). Josifa Ročko darbā "Holokausts Latgalē" ir sīki aprakstīts šis traǵiskais notikums. 1941. gada jūlijā kādai ebrejietei esot piedzimis bērns, bet "sanitāre B. V. esot sagrābusi jaundzimušo ebreju bērnu un saspiedusi tam galvu" (Rochko 2003, 114). Savukārt feldšeris (?) B., ejot uz darbu pa Rīgas ielu, kādā mājas pagalmā esot pamanījis ebrejieti (?) Hovomišli, izvilcis ieroci un viņu nošāvis (Rochko 2003, 114). Kā liecina novadpētnieciskajā izdevumā "Varakḷāni un varakḷānieši" pieejamā informācija, feldšeris P. B. tiešām ir strādājis Varakḷānu slimnīcā un "1937. gadā [..] izvadīts pensijā". To apliecina fotoattēls, kurā viņš redzams kopā ar citiem Varakḷānu slimnīcas darbiniekiem (Blusanovičs 2003, 162). Tie ir atsevišksi gadijumi un nevar tikt vispārināti. Šādam viedoklim netieši piekrīt Josifs Ročko, uzsverot, ka vairākums no vietējiem iedzīvotājiem "jutuši līdzi ebrejiem un citi pat viṇiem palīdzējuši, lai arī par to draudējis bargs sods" (Rochko 2003, 114).

Tomēr jāatzīst, ka, tāpat kā lielākā daḷa Latvijas iedzīvotāju, arī starp vietējiem varakḷāniešiem absolūtais vairākums bija t. s. malā stāvētāji, tostarp intervētie respondenti. Kā atzīmē holokausta sociālās atminas pētnieks Didzis Bērzin̄š, pēdējos gados holokausta izpētē aizvien biežāk tiek analizēta malā stāvētāju atbildība attiecīgā nozieguma kontekstā, un tāpēc būtiska ir atziņa, ka iepriekš minētā cilvēku grupa ir "līdzvainīga holokausta notikumos" (Bērziņš 2015, 133). Konkrētajā grupā ietilpa dažādu kategoriju cilvēki (gan pēc religisiskās pārliecības, gan sociālā stāvokḷa u. c.), tomēr viṇu "neitralitāte" nekavēja nozieguma attīstības dinamiku, līdz ar to veidojas indivīda individuālā atbildība (tai skaitā morālā) pret saviem līdzcilvēkiem, šajā gadījumā ebrejiem.

Jāatzīst, ka varakḷāniešu atmiṇās nav nosodījuma nacistu darbībām pret ebrejiem. Tas izskaidrojams ar atmiṇām par vietējo latviešu līdzdalību ebreju iznīcināšanā. Tā, piemēram, J. B. uzsver, ka "vāciets jau pats nešāva, latvieši šāva" (J. B. 2014). Savukārt V. B. izteica viedokli, ka "latviešiem ar vāciešiem bija labas attiecības” (V. B. 2014), sīkāk nepamatojot 
šo draudzīgo attiecību iemeslu. Kā izsakās vēsturnieks Inesis Feldmanis, tad parasti tiekot norādīts, ka "baigais gads, padomju represijas radīja latviešos nospiestību, nolemtības sajūtu un tādu naidu pret krievu okupantiem, ka daudzi "mūžsenos ienaidniekus" vāciešus tagad uztvēra un sveica kā atbrīvotājus un cilvēki jutās kā izglābušies no nāves, atguva dzīvot prieku, pašcieņu un cerības. Viniiem likās, ka pēc gada "prombūtnes" Latvija ir no jauna atgriezusies Eiropā" (Feldmanis 2007). Tādējādi ar savām darbībām padomju okupācijas režìms pat nenojaušot bija radījis "labvēlīgus" apstākḷus jaunajam vācu okupācijas režīmam Latvijā. Toties visās intervijās ir izteikti negatīvs vērtējums par vietējo iedzīvotāju dalību šajos trag̣iskajos notikumos.

\section{NOZIEGUMA "SLËPŠANA"}

Daudziem varaklāniešiem ir saglabājušās atmiņas par ebreju masu iznīcināšanas vietas dedzināšanu. V. B. norāda, ka šajā dienā "smirdējusi visa pilsēta, bet tad vēl pati neesot apjautusi, kāpēc tas notiek" (V. B. 2014). Ebreju kapu dedzināšanu atceras arī Velta Bāliṇa. Stāstot, ka kādu dienu, ejot uz Varakḷāniem, ap ebreju kapiem bijis "apjozts brezenta "žogs", pacēlušies dūmi un viṇa sapratusi, ka nošautie ebreji tiekot rakti ārā un dedzināti" (Bāliṇa 2002, 5). A. G. norāda, ka ebreju dedzināšanā bija iesaistīti padomju karagūstekṇi no Rēzeknes (tostarp ebreji), kuri pēc tam paši tikuši nogalināti un sadedzināti. Par šiem notikumiem viņam stāstījis iepriekš minētais "šucmanis" no Saikavas, atzīmējot faktu, ka ebreju mirstīgo atlieku iznīcināšanas procesa laikā ticis iegūts aptuveni astoņi kilogrami zelta (S. G. 2015). Uz Varakḷānos notikušo ebreju masu kapu dedzināšanu norāda arī Josifs Ročko, rakstot, ka "1944. gadā vācieši uz Varakḷāniem atdzinuši kara gūstekņus, kuri esot izrakuši nošautos ebrejus un tos sadedzinājuši. Vēlāk gan paši gūstekņi turpat kapos esot nošauti” (Rochko 2003, 115). Šajā gadījumā iepriekš minētajiem respondentiem ir kolektīvās atmiņas iezìmes, kas apliecina latviešu tautības iedzìvotāju nosodījumu pret holokausta zvērībām, ko pamato Marija Klēra Lavabrē (Marie-Claire Lavabre), rakstot, ka "kolektīvā atmiṇa var tikt definēta kā mijiedarbība starp atmiṇas politiku dēvēta arī par "vēsturisko atmiṇu" - un atmiṇām - "kopīgo atmiṇu" par to, kas ir kopīgi pieredzēts" (Lavabre 1994). Visdrīzāk iepriekš minētajās atmiņās respondenti atspogụ̣o nacistiskās Vācijas okupācijas varas iestāžu īstenoto operāciju ar kodēto nosaukumu "1005" ("Sonderaktion 1005") Latvijas teritorijā akcija sākās 1944. gada aprīlī, tās laikā notika sistemātiska ebreju masu iznīcināšanas vietu (bedru) atrakšana un lịku iznīcināšana (dedzināšana), piemēram, Daugavpilī (Arad 2009, 353), tādējādi cenšoties slēpt holokausta noziegumu pēdas. 
V. B. norāda uz savu neizpratni par to mūsdienās: "augustā, kad ebreji pulcējas un piemin holokaustā bojāgājušos, tas nenotiek tajā vietā, kur risinājās trağēdija, bet gan kapos" (V. B. 2014). Teicēja pieḷauj domu, "ka tam par iemeslu ir iepriekš nogalināto ebreju dedzināšana, kas notikusi pēc vāciešu pavēles, pirms viṇi atkāpās no pilsētas" (V. B. 2014). Jāpiemin fakts, ka katru gadu augusta pirmajā svētdienā Varakḷānu ebreju kapos notiek piemiņas pasākums, kurā piedalās kādreiz pilsētā dzīvojošie ebreji, viṇu pēcnācēji, kā arī vietēji iedzīvotāji.

\section{SECINĀJUMI}

Holokausta notikumi līdz pat mūsdienām saglabājušies daudzu varakḷāniešu atmiņās, kurās atspogul,ojas konkrēto notikumu norise. Tāpat intervijās atklājas respondentu negatīvā attieksme pret atsevišķ vietējo iedzīvotāju līdzdalību holokausta notikumos. Tomēr intervējamie nacistu darbības pret ebrejiem l,oti nenosoda. Tas varētu būt izskaidrojams ar nacistiskās Vācijas īstenoto propagandu Latvijas teritorijā attiecīgajā laika posmā, kā arī ar atmiņām par vietējo latviešu iesaisti ebreju iznīcināšanā. Respondentu izteiktie viedokḷi l,auj secināt, kā laika gaitā iepriekš minēto notikumu atcerēšanos ietekmējuši vairāki faktori (vecums, izglītība, informācijas avots u. c.), kas atspoguḷojas dažādās informācijas interpretācijās. Teicēju sniegtajās atminās atklājas vietējo iedzīvotāju kolektīvās un sociālās atmin,as iezīmes, respektīvi, interviju naratīvā (vai nu pozitīvā vai krasi negatīvā) atbalsojas respondentu personīgā dzīves pieredze. Tajās ietverto informācijas līmeņu analīze atklāj, vai intervējamais stāstīto piedzīvojis personīgi vai dzirdējis un aizguvis no laikabiedriem.

\section{SAĪSINĀJUMI}

MEL - Muzejs Ebreji Latvijā

\section{IZMANTOTIE AVOTI UN LITERATŪRA}

\section{AVOTI}

G. Vìtolas intervija ar J. B. $1930^{6}$ [latviešu val.], 2014. Autores personīgais arhīvs, 1. lieta. K. Stroda intervija ar A. S. 1939 [latgaliešu val.], 2013. Autora personīgais arhīvs, 1. lieta. K. Stroda intervija ar A. S. 1939 [latgaliešu val.], 2014. Autora personīgais arhīvs, 4. lieta. K. Stroda intervija ar A. V. 1923 [latviešu val.], 2013. Autora personīgais arhīvs, 2. lieta. K. Stroda intervija ar S. G. 1926 [latgaliešu val.], 2014. Autora personīgais arhīvs, 5. lieta. K. Stroda intervija ar V. B. 1924 [latgaliešu val.], 2014. Autora personīgais arhīvs, 3. lieta. 
K. Stroda, A. Pečerskajas intervija ar B. S. 1928 [latgaliski un latviski], 2015. Autora personīgais arhìvs, 8. lieta.

K. Stroda, M. Gehtas intervija ar B. D. 1927 [krievu val.], 2014. Autora personīgais arhivs, 6. lieta.

K. Stroda, M. Gehtas intervija ar S. G. 1926 [latgaliešu val.], 2015. Autora personīgais arhivs, 7. lieta.

Latvijas ebreju kopienas vēsture [angḷu val.]. 1990. Muzejs "Ebreji Latvijā” (MEL), D (3) B - 780. Izraēlā: Museum of the Jewish Diaspora, 3.

S. Zaķa intervija ar A. G. 1935 [latviešu val.], 2014. Autora personīgais arhīvs, 1. lieta. Skolotājas V. Bāliņas atmin,as par Goldbergu ǵimeni Stirnienes muižā, vēlāk Varakḷānos 20. gs. 30. gados un 1940.-1941. gadā [latviešu val.], 2002. MEL, D (3), 3101, pl. 7236.

\section{LITERATŪRA}

Arad, Y., 2009. The Holocaust in the Soviet Union. Lincoln: University of Nebraska Press.

Bauer, Y., 1978. The Holocaust in Historical Perspective. Seatle: University of Washington Press.

Bela-Krūmiņa, B., 2001. Patība un sociāli kulturālais konteksts. Zirnīte, M. Spogulis. Rìga: LU Filozofijas un sociologíijas institūts, 75-85.

Blusanovičs, J., 2003. Veselības aprūpe Varakḷānos. Sondors, K. Varakḷāni un varakḹānieši. Rēzekne: Latgales Kultūras centra izdevniecība, 161-169.

Egle, V., 2013. Dienasgrāmata Vecordia L-EZERG1: Andrievs Ezergailis. Holokausts Latvijā. Grīziņkalns: Impositum.

Ezergailis, A., 1999. Holokausta vācu okupētajā Latvijā 1941-1944. Rīga: Latvijas Vēstures institūta apgāds.

Feldmanis, I., 2007. Vācu laiks: pētniecības problēmas un risinājumi. Pieejams: http:// klab.lv/community/vesture/18935.html (skatìts 26.04.2015.)

Hilberg, R., 2003. The Destruction of the European Jews. Yale University Press. Pieejams: http://www.history.ac.uk/reviews/review/394 (skatìts 19.04.2015.)

Holokausts. Pieejams: http://vesture.eu/index.php/Holokausts (skatīts 10.04.2015.)

Hunt, N. C., 2010. Memory, War and Trauma. Cambridge: Cambridge University Press.

Kantola, A., 2014. The therapeutic imaginary inmemory work: Mediating the Finnish Civil War in Tampere. Helsinki: University of Helsinki. Pieejams: http://mss.sagepub. com/content/7/1/92.abstract (skatîts 22.04.2015.)

Lavabre, M. C., 1994. For a Sociology of Collective Memory. Pieejams: http://www.cnrs. $\mathrm{fr} / \mathrm{cw} / \mathrm{en} / \mathrm{pres} / \mathrm{compress} / \mathrm{memoire} /$ lavabre.htm (skatìts 14.04.2015.)

Mihelsone, F., 2014. Es izdzìvoju Rumbulā. Rēzekne: Latgales Druka.

Plakans, A., Purs, A., 2017. Historical dictionary of Latvia. Third edition. Lanham: Rowman \& Littlefield.

Rochko, I., 2003. Varakliani. Shteiman, I., Olekhnovich, D., Volkovich, B., u. c. Holokost $v$ Latgalie. Daugavpils: Daugavpilsskaja evreiskaia obshina, 109-116.

Ročko, J., 2008. Holokausts Latgalē: Rēzekne, Ludza, Krāslava, Varakḷāni. Menahems, B. Ebreju iznicināšanas vietas 1941.-1945. Rīga: Šamir, 209-214.

Smirins, G., 2006. Rīgas ebreji nacistiskās okupācijas laikā (1941-1944). Caune, A. Latvijas Vēsturnieku komisijas raksti, 18. sējums: Holokausts Latvijā. Rīga: Latvijas vēstures institūta apgāds, 83-117. 
Stranga, A., 2004. Holokausts Latvijā: 1941-1945. Caune, A. Holokausta izpēte Latvijā. Starptautisko konferenču materiāli, 2003. g. 12.-13. jūnijs, 24. oktobris. Rīga; 2002.-2003. g. pētijumi par holokaustu Latvijā (Latvijas Vēsturnieku komisijas raksti, 12. sējums). Rịga: Latvijas Universitātes Latvijas vēstures institūta apgāds, 209-224.

Stranga, A., 2008. Holokausts vācu okupētajā Latvijā: 1941-1945. Caune, A. Latvijas Vēsturnieku komisijas 23. sējums: Holokausta pētniecỉbas problēmas Latvijā. Rīga: Latvijas vēstures institūta apgāds, 21-29.

Vīksne, R., 2004. Ebreju iznīcināšana Latvijas mazpilsētās: pētniecības problēmas un rezultāti. Caune, A. Latvijas Vēsturnieku komisijas raksti, 12. sējums: Holokausta izpēte Latvijā. Rīga: Latvijas vēstures institūta apgāds, 41-48.

\section{ATSAUCES UN PIEZĪMES}

${ }^{1}$ Intervēto respondentu, kā arī intervijās un citos mutvārdu avotos pieminēto personvārdu saīsinājumi.

${ }^{2}$ Arāja komanda bija paramilitāra vienība, kura Otrā pasaules kara laikā piedalījās vairāku tūkstošu Latvijas teritorijā dzīvojošu ebreju masu iznīcināšanā (tostarp Rumbulas akcijās 1941. g. ziemā). Tāpat daḷa vienības tika iesaistīta pretpartizānu akcijās Latvijas austrumos (Latgalē), Baltkrievijas un Krievijas teritorijās 1942. un 1943. g. Tās vadītājs bija Viktors Arājs (Purs, Plakans 2017, 33).

${ }^{3}$ Latvijas Republikas (1918-1940) laikā ražotie pasažieru autobusi, kurus nacistiskās Vācijas okupācijas laikā izmantoja Arāja komandas dalībnieki, izbraucot uz ebreju iznīcināšanu dažādās Latvijas pilsētās.

${ }^{4}$ Šucmanis - nacistiskās Vācijas okupētajās teritorijās tā sauca koloboracionistus, kuri iestājušies nacistu izveidotajās policijas vienībās. (Šucmanni. Pieejams: http:// vesture.eu/index.php/\%C5\%A0ucma\%C5\%86i (skatīts 10.04.2015.).)

${ }^{5}$ Operācija tika uzsākta 1942. g. vasarā, lai iznīcinātu liecības par nacistiskās Vācijas īstenoto ebreju u. c. Padomju Savienības okupēto teritoriju iedzīvotāju masu iznīcināšanu Otrā pasaules kara laikā (Arad 2009, 347).

${ }^{6}$ Respondenta dzimšanas gads. 


\title{
JEWS IN THE COMMUNICATIVE MEMORY OF THE INHABITANTS OF VARAKLĀANI AND THE SURROUNDING AREA: THE HOLOCAUST
}

\author{
KASPARS STRODS \\ MA in archival science, Ph.D. student in programme "History" at Daugavpils University, \\ Historian at Latgale Culture and History Museum
}

\begin{abstract}
The paper aims to summarise and analyse the oral interviews with the local residents, as well as memories available in written sources about the events of the Holocaust in Varakḷanni. The study focuses on several oral interviews with the local residents of Varakḷāni and its neighbourhood, which, placed in the context with other materials, allow better to understand the course of events and the local residents' attitude towards Jews in the respective historical situation.
\end{abstract}

Keywords: the Holocaust, social memory, Jews, Varak!̣̄ani.

\section{SUMMARY}

The Second World War and the Holocaust are among the most widely studied topics in Latvian historiography. In recent years, the research into the course of the Holocaust in those towns in Latvia, where the majority of the population consisted of Jews (including Latgale) has become topical. One of such towns was Varakḷāni, where according to the historical data from the census of 1935, of 1661 citizens 952 or $57.32 \%$ were Jews. The large Jewish community of Varaklāni was almost completely exterminated during the Holocaust. The above-mentioned events have stayed in the memory of several Varakḷāni inhabitants; they reveal the tragic fate of the Jewish people. The data collected from the interviews with the local residents reflect the respondents' negative attitude to the participation of some local residents in the events of the Holocaust. However, the interviewees do not express any judgemental attitude towards the Nazi actions against the Jews that could be explained by the impact of the Nazi German propaganda in the territory of Latvia during the relevant period, as well as the memories about the involvement of the local Latvians in the extermination of Jews. The narrative (both positive and harshly negative) of the interviews reflects the respondents' personal life experience. 


\title{
LATVIJAS MĀKSLAS AKADĒMIJAS AKADËMISKĀS STUDENTU ORGANIZĀCIJAS (1923-1940): TO LOMA SABIEDRĪBĀ UN JAUNO MĀKSLINIEKU PROFESIONĀLAJĀ IZAUGSMĒ
}

\author{
AGNIJA LESNIČENOKA \\ Mg. hist., Latvijas Mākslas akadēmija \\ E-pasts: agnija.lesnicenoka@gmail.com
}

\begin{abstract}
ANOTĀCIJA
Pēc Latvijas Republikas proklamēšanas un pirmo Latvijas augstskolu dibināšanas Latvija piedzīvoja strauju jaunatnes plūšanu uz galvaspilsētu Rīgu, lai iegūtu augstāko izglītību. Studenti līdztekus studijām sāka veidot savu akadēmisko jaunatnes dzīvi. Šajā laikā arī Latvijas Mākslas akadēmijas (turpmāk - LMA) studenti sāka meklēt veidus, kā izveidot savas organizācijas. 1923. gadā LMA studenti nodibināja pirmo LMA studējošo organizāciju - studentu korporāciju "Dzintarzeme". 1929. gadā nodibināja studenšu biedrībukorporāciju "Veidola", bet 1933. gadā - studentu vienotni "Zaḷā zeme". Pētījuma mērḳis ir noskaidrot, kāda bija LMA akadēmisko studentu organizāciju loma biedru profesionālajā izaugsmē Latvijas akadēmiskajā vidē un sabiedrībā.
\end{abstract}

Atslēgas vārdi: Latvijas Mākslas akadēmija, studentu organizācijas, 20. gadsimts, starpkaru periods, “Dzintarzeme”, “Veidola", "Zạ̣ā zeme".

\section{IEVADS}

Augstskola ikkatram asociējas ar augstākās izglītības iegūšanu, taču tā laika gaitā bijusi arī vide, kur dzimušas un pastāvējušas dažādas akadēmiskās studentu organizācijas. Latvijā būtiskas vēstures liecības ir atstājušas akadēmiskās slēgtās mūža organizācijas, kurām bijusi liela nozīme, jo tās ne tikai vienkopus pulcināja latviešu studentus, bet arī palīdzēja veidot Latvijas valsti Pirmā pasaules kara laikā un starpkaru posmā, kā arī apvienoja latviešu tautas izglìtoto daḷu un veicināja tautiskās domas rašanos. 
Akadēmiskums ir saistīts ar augstākajām mācību iestādēm un nozīmē to, ka šo organizāciju biedriem bija jābūt augstāko mācību iestāžu audzēkṇiem vai absolventiem. Kā slēgtām organizācijām tām bija raksturīga biedru atlase, kas notika saskaņā ar iekšējiem noteikumiem un organizācijas mērkiiem, un kā mūža organizācijās tajās bija iespējams darboties visu mūžu neatkarīgi no tā, vai persona ir students vai augstskolas absolvents.

Pēc Latvijas Republikas proklamēšanas latviešu studentu akadēmiskajā vidē dominēja divu tipu latviešu studentu organizācijas. Pirmās bija studentu korporācijas, kuras tika veidotas, balstoties uz citu tautu studentu korporācijām, ar senu, stingru reglamentāciju, tradīijām un latīṇu valodas apzīmējumiem korporācijas nosaukumos (piem., Lettonia, Fraternitas Arctica, Lettgallia, Fraternitas Lettica u. c.), sadzìves un tradīciju terminos. To attaisnoja ar patriotiskiem motīviem - vēlme izkarot latviešiem cienījamu stāvokli, pierādìt latviešu studentu līdzvērtību vācu studentiem. Otrs tips bija biedrības (vienotnes, vienības, apvienības), kas nepieņēma korporāciju iekārtu (Auls 1960, 69). Tās pievērsa mazāku vērību organizācijas veidam, tām nebija iekšêjās dzìves reglamentācijas, un tām bija raksturīgs uzsvērts latviskums. Visām šìm organizācijām bija latviski nosaukumi. Līdz ar to starpkaru periodā latviešu studentu saime bija sadalījusies divās atškirīigās un nedraudzīgās nometnēs. Šajā strauji pulsējošajā laikā arī Latvijas Mākslas akadēmijas studenti sāka meklēt veidus, kā organizēt savas biedrības, nodibinot studentu korporāciju "Dzintarzeme", biedrību-korporāciju "Veidola" un vienotni "Zaḷā zeme". Tās pien̦ēma citu tautu studentu korporāciju tradīcijas, kā, piemēram, studentu korporācija "Dzintarzeme", un mēǵināja pielāgoties biedrībām ar izteikti latvisku ideolog̣iju, kā tas bija vienotnē "Zạ̣ā zeme". LMA studentu organizāciju dibināšana bija daudz savdabīgāka nekā citu Latvijas studentu korporāciju vai biedrību veidošana, jo Latvijā līdz šim nebija sastopamas studējošo latviešu mākslinieku akadēmiskās organizācijas, tāpēc ìpatnējos apstākḷ̆os radās jaunas, piemērotas formas un iekšējās tradīiijas.

Pētījuma mērķis ir noskaidrot, kāda bija LMA studentu organizāciju loma biedru profesionālajā izaugsmē Latvijas akadēmiskajā vidē un sabiedrībā. Pētijjuma hronolog̣iskās robežas ietver starpkaru laiku no 1923. gada, kad tika dibināta pirmā LMA studentu organizācija, līdz 1940. gadam, kad PSRS okupēja Latviju un visu LMA akadēmisko organizāciju darbība tika pārtraukta.

Sabiedrības uzmanības lokā līdz šim lielākoties ir bijušas lielākās un senākās latviešu studentu korporācijas, kuras ieguvušas atpazīstamību, pateicoties to ievērojamiem biedriem, nozīmīgiem nopelniem Latvijas valsts labā. Turpretim maz pētîtas ir citas studentu organizācijas, kuru skaits mērāms vairākos desmitos un kuras bija raksturīga un neatnemama studentu akadēmiskās dzīves sastāvdaḷa 20. gs. 20., 30. gadu Latvijā. Maza uzmanība veltīta arī LMA studentu organizācijām - tās ir unikālas un nozīmīgas ar to, 
ka tās atškīīās no visām Latvijas studentu organizācijām kā pirmās studējošo latviešu mākslinieku akadēmiskās organizācijas Latvijā, kuras pulcināja ap sevi tikai LMA studentus. Kā analoǵisku organizāciju var minēt 19. gs. nogalē Pēterpilī dibināto latviešu apvienību "Rūksis", taču tā atšḳīās, pirmkārt, ar to, ka apvienība tika dibināta pirms Latvijas proklamēšanas un ārpus tās teritorijas. Otrkārt, apvienība atškīīās ar savu sastāvu, jo tajā pulcējās ne tikai mākslinieki, bet arī citi latviešu sabiedriskie darbinieki, treškārt, tā pulcēja vairāku augstskolu studentus, ceturtkārt, birokrātisku šḳēršḷu dēḷ apvienība nevarēja tikt legalizēta.

Ziṇas par LMA akadēmiskajām studentu organizācijām aptver gan publicētos, gan nepublicētos avotus. Dzintarzemes darbību starpkaru periodā laika posmā no 1924. līdz 1940. gadam -, pētot tās iekšējās un ārējās dzīves norises, tradīciju un ideoloǵijas nostiprināšanos, iespējams skatīt Latvijas Nacionālā arhīva Latvijas Valsts vēstures arhīva (turpmāk - LNA LVVA) 2477. fondā "Latvijas Mākslas akadēmijas audzēkṇu biedrība "Dzintarzeme"” un LNA LVVA 1969. fondā "Latvijas studentu biedrības". Pievēršoties trimdas laikam, kā vērtīgu materiālu bāzi jāmin trimdas periodika, kas vērtējama kā l,oti nozīmīgs Latvijas kultūras vēstures avots. Dzintarzemiešu trimdas seniors Jānis Audriņš pastāvīgi publiskojis rakstus trimdas latviešu laikrakstos "Laiks" (Amerika), "Brīvā Balss" (Kanāda) (vēlākais nosaukums "Latvija Amerikā"), "Austrālijas Latvietis" (Austrālija) par "Dzintarzemes" vēsturi, korporācijas gaitām trimdā. Kā vēl viens nozīmīgs informācijas resurss pētījuma tapšanā minamas pašu dzintarzemiešu atstātās liecības. Vērtīgs informācijas avots ir tēlnieka Vernera Dukura fonds LNA LVVA 2061. fondā, kurā apkopota sarakste starp dzintarzemiešiem un korporācijas protokoli trimdā. Par studenšu korporāciju - biedrību "Veidola" - informācija iegūstama LNA LVVA 5034. fondā "Latvijas Mākslas akadēmijas studenšu biedrība korporācija "Veidola"”. Ziņas par studentu vienotni "Zaḷā zeme" rodamas LNA LVVA 1969. fondā "Latvijas studentu biedrības", kā arī Latvijas starpkaru perioda laikrakstā "Students".

Historiogrāfijā par latviešu studentu akadēmisko organizāciju vēsturi visaptverošus darbus izdevuši vēsturnieks Dr. hist. V. Ščerbinskis grāmatā "Uzticīgi draugam" un mecenāts, korporācijas Fraternitas Lettica filistrs Dr. chem. Pēteris Bolšaitis darbā "Vivat Academia". Minētajos darbos apkopota informācija par korporāciju izcelšanās vēsturi Vācijā, Tērbatā un Rīgā, kā arī fundamentāli fakti par Latvijā pastāvējušajām studentu akadēmiskajām organizācijām. Par latviešu studentu akadēmisko organizāciju vēsturi rakstīts arī atsevišḳu studentu akadēmisko organizāciju jubileju albumos un par kopējo vēsturi - izdevumos "Universitas" un "Akadēmiskā Dzīve". Par mazāk zināmām korporācijām, kuras savu darbību beigušas pēc 1940. gada, informācija ir pieejama nepilnīga un fragmentāra, un to nepieciešams salīdzināt ar citiem vēstures avotiem, lai pārliecinātos par to 
patiesumu. Dr. hist. V. Ščerbinskis centies savā darbā minēt pilnīgi visas studentu organizācijas, kas pastāvējušas Latvijā, veltot mazāk zināmai organizācijai kaut vai tikai dažas rindkopas un padarot monogrāfiju "Uzticīgi draugam" par fundamentālāko vadlīniju turpmākiem pētniecības darbiem attiecībā uz mazāk zināmajām studentu organizācijām.

\section{STUDENTU KORPORĀCIJA “DZINTARZEME”}

1923. gada 19. martā Latvijas Mākslas akadēmijas studenta Roberta Vītoliṇa (1900-1974) šaurajā istabiṇā ar vēl 11 topošajiem māksliniekiem tika nodibināta pirmā Latvijas Mākslas akadēmijas studentu organizācija - korporācija "Dzintarzeme". 1924. gada 19. martā tā reǵistrēta Rīgas apgabaltiesā (Ščerbinskis 2010, 167). 1924. gada 27. martā notika oficiālā biedru-dibinātāju sapulce, kurā korporācijas dibinātājiem piešḳīra regāliju nēsāšanas tiesības (LNA LVVA, 2477-1-2, 1. 1p.). Latvijas Mākslas akadēmijas vadība uz "Dzintarzemes" dibināšanu skatījās labvēlīgi. Tā kā vecāku un līdzīgu jaunās Mākslas akadēmijas organizāciju 1923. gadā nebija, par paraugu organizācijas uzbūvei, sadzìves organizēšanai un paukošanā ņēma Vīnes Mākslas akadēmijas korporācijas "Athenea" komānu, piemērojoties vietējiem apstākḷiem (Laiks 1958, 3). Tikai no 1926. līdz 1927. gadam pēc iekšējās uzbūves un tradīcijām organizācija sāka līdzināties Latvijas Universitātes korporācijām (1. attēls).

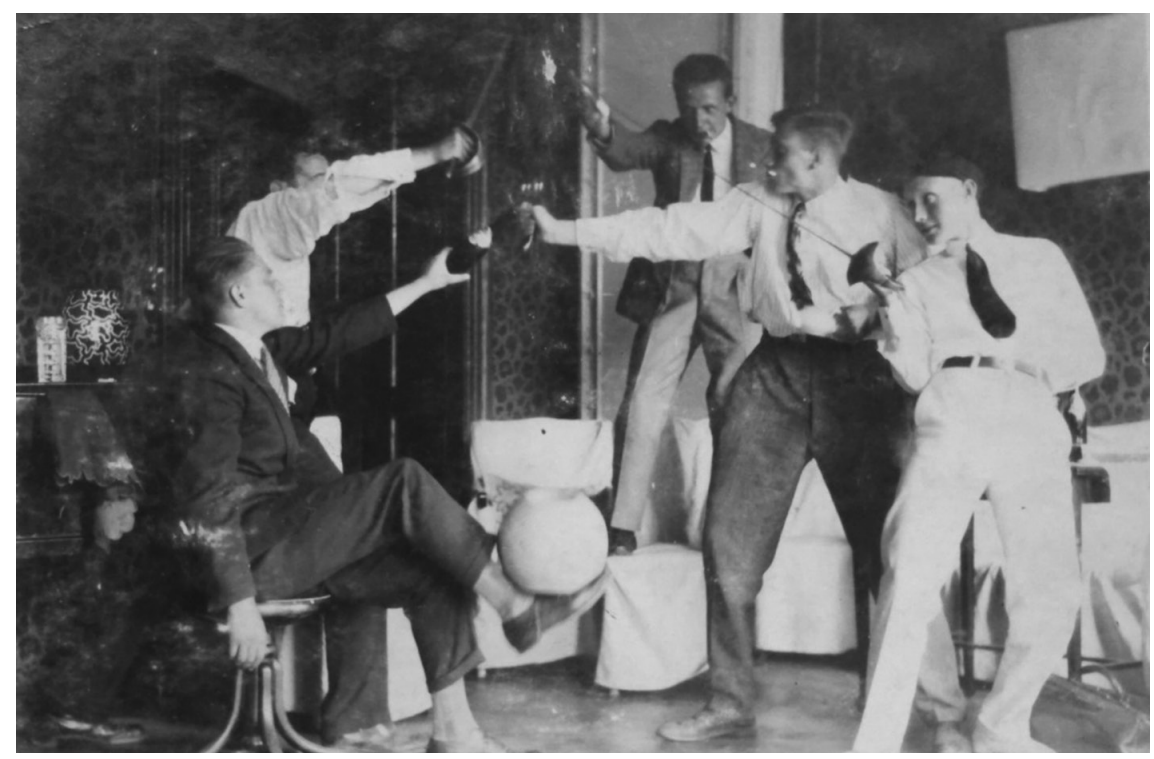

1. attēls. Dzintarzemiešu paukošanas nodarbība, 30. gadi (LNA-LVA, 1601, 1-1. 7/57). 
"Dzintarzemes" mērḳis bija apvienot nacionāli domājošos Latvijas Mākslas akadēmijas audzēkṇus nacionālās mākslas un pašizglītības veicināšanai, attīstot audzēkņos individuālo goda apziņu un atbalstot savus biedrus materiāli un morāli. Šie mērki nebija rakstîti tikai uz papīra, bet veiksmīgi darbojās dzīvē. Attiecībā uz biedru atbalstu Latvijas Valsts vēstures arhīva 2477. fonda dokumentos rodamas ziņas, ka ir bijuši gadijumi, kad kāds biedrs nav spējis samaksāt mācību maksu LMA, kas bija ap 200 Ls gadā. Visbiežāk, lai novērstu šādas situācijas, konvents iespēju robežās mēgeināja palīdzēt nomaksāt parādu. Korporācijas uzdevumos ietilpa "māksliniecisko parādību iztirzāšana, izpratne un apgūšana, savu biedru audzināšana tautiskā garā, vienības un kopības jūtu izkopšana, krietnu tautiešu izaudzināšana" (LNA-LVA, 2061-1-1, 1.-13. 1p.). "Dzintarzemes" nostādnes atspogulıjās arī tās devīzē "Dailei, draugam, dzintarzemei" un regālijās, piemēram, tās karoga krāsās - melns, dzeltens, zils. Melnā krāsa simbolizēja drūmo ikdienu, kurā kā koša zvaigzne mirdzēja māksla, dzeltenā - dzimtenes druvas un zilā - mākslas ideālu tāles (Latvis 1933, 3).

Saskaņā ar komānu un iekšējo ideolog̣iju korporācijas biedriem bija jārāda priekšzime - nedrīkstēja uz ielas smēḳēt, bija jāzina pieklājības normas, noteikti jāmāk dejot, jābūt nacionāli noskan,otam, godīgam, jātur dotais vārds. Bija jāzina mērs alkoholisko dzērienu lietošanā. Ja biedrs atradās neadekvātā stāvoklī, par to draudēja izslēgšana no korporācijas uz laiku. Ja tautietis jeb pilntiesīgais loceklis rīkojās necienīgi, viṇš stājās iekšejās goda tiesas priekšā. Biedriem bija kārtīgi jāapmeklē lekcijas, jāliek eksāmeni un jācenšas gūt izcilas sekmes akadēmijā (LNA-LVA, 2061-1-1, 1.-13. lp.). Lai gan tas skan pēc ideāli piekoptas disciplīnas, reālajā dzīvē savu reizi notikuši dažādi precedenti, un lỉdz ar to atstātas dokumentētas liecības ienākošajos rakstos par dažādiem pārkāpumiem un goda tiesām (LNA LVVA, 2477-1-12).

Starpkaru periodā "Dzintarzemes" iekšējā dzīve ritēja jaunības entuziasmā. Dzintarzemieši aktīvi nodevās nopietniem referātu vakariem par mākslu un literatūru, kā arī vadīja diskusijas. Aktivitāšu sarakstā bija arī mākslinieku biedrību izstāžu kritika, "Dzintarzemes" iekšējās un publiskās mākslas darbu izstādes ar iespēju pilnveidot savas mākslinieciskās spējas, popularizēt sevi un pārdot gleznas korporācijas kases papildināšanai. Nopietni brǐži mijās arī ar bohēmiskiem mirkḷiem, taču rosīgā interese par mākslas problēmām izcēla dzintarzemiešus. Laikraksts "Students" 1929. gadā veltīja atzinīgus vārdus korporācijai - "Pagaidām savā apmēram 40 personu sastāvā tā ir visorganizētākā akadēmijas audzēkṇu daļa" (Students 1929, 2). Šãdu atzinību dzintarzemieši noteikti izpelnij̄ās ne tikai tāpēc, ka ievēroja korporācijas reglamentu un vēlējās būt līdzvērtīgi līdzās citām korporācijām, bet arī atbildības dẹl - viṇi apzinājās savu atbildību pret Latvijas Mākslas akadēmijas mācībspēkiem. Akadēmijas mācībspēki - prof. Vilhelms Purvītis, prof. Jānis 
Kuga, prof. Pēteri Feders, prof. Rihards Zarinšs, prof. Jānis Tilbergs, prof. Rūdolfs Pelše, doc. Burkards Dzenis, Jānis Tilbergs, Kārlis Miesnieks, Alberts Prande, Konstantīns Rončevskis - aktīvi izrādīja interesi par dzintarzemiešu dzīvi un labprāt viesojās to sarīkojumos, bet vēlāk kḷuva par "Dzintarzemes" goda filistriem (Laiks 1973, 3) (2. attēls). Viṇu zināšanām un pieredzei mākslā bija liela nozīme dzintarzemiešu saimē, jo ikkatrs dzintarzemietis varēja pārrunās un referātu vakaros gūt izpratni par dažādiem mākslas jautājumiem. Ieksējās izstādēs tika ielūgti viesi un goda filistri, lai tie sniegtu kritiku par darbiem. Filistri parasti centās pakavēties pie katra darba, izvērtējot pozitīvās un negatīvās puses. 1928. gadā notika pirmā iekšējā izstāde, kurā kritiku izteica prof. Pēteris Feders (LNA LVVA, 2477-1-6, 4. lp.).

"Dzintarzemes" piekoptās ideolog̣ijas ietekmē dzintarzemieši vairāk sekoja latviešu vecmeistaru glezniecības piemēriem un to paustajām idejām, kā arī latviešu nacionālajai mākslai. Šì parādība visai zīmīga, jo vairums dzintarzemiešu studiju laikā auga reizē ar latviešu glezniecības tradīcijām, kas ir starpkaru Latvijas ievērojams mantojums. Daudzi dzintarzemieši, darbodamies šo tradīciju garā, guva panākumus un kḷuva ievērojami latviešu mākslas dzīvē trimdā, kā arī okupētajā Latvijā (Latvija Amerikā 1958, 5). Smagie politiskie notikumi 1940. gadā, kad PSRS okupēja Latviju, pārtrauca "Dzintarzemes" darbību Latvijā un radīja krietnu robu skaitliski nelielajās dzintarzemiešu rindās. Daļa dzintarzemiešu tika deportēti, krita karā vai pazuda bez vēsts, taču otra daḷa bija izvēlējušies trimdas ceḷu, turpinot pēckara dzīvi svešumā, kur dzintarzemieši dzīvoja līdzi savas valsts un tautas likten,iem.

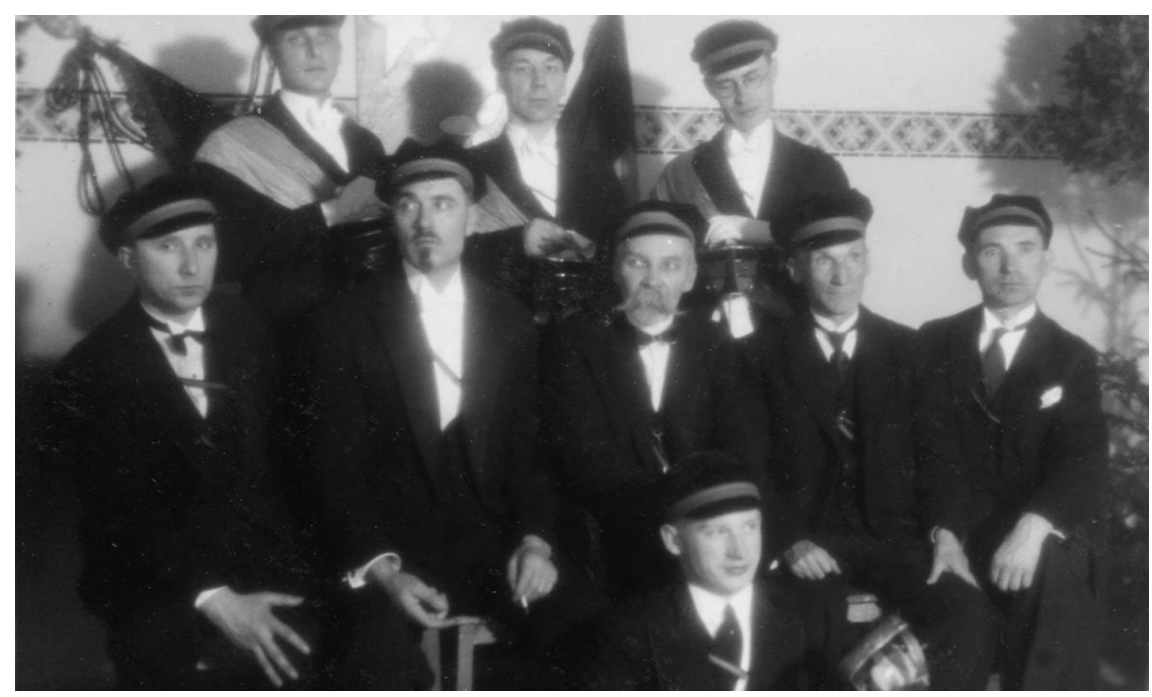

2. attēls. Latvijas Mākslas akadēmijas korporācijas "Dzintarzeme" biedri kopā ar filistriem. 2. rindā no kreisās: 2. - Kārlis Miesnieks, 3. - Rihards Zariṇš, 4. - Teodors Zeiferts, 30. gadi. No Cēsu Vēstures un mākslas muzeja krājuma (CM 100961). 


\section{STUDENŠU KORPORĀCIJA-BIEDRĪBA "VEIDOLA"}

Studenšu biedrība-korporācija "Veidola" tika izveidota 1928. gada novembrī, bet 1929. gada 24. janvārī LMA izdeva apliecību par atḷauju darboties un iesniegt statūtus reǵistrēšanai likumā paredzētā kārtībā (LNA LVVA, 5034-1-1, 9. lp.). Rīgas apgabaltiesa "Veidolas" statūtus apstiprināja 1929. gada 27. februārī (Valdības Vēstnesis 1929, 6). Arī "Veidola" centās pielāgoties korporāciju tradīcijām. "Veidolas" mērḳi un ideologija bija l̦oti līdzīga "Dzintarzemei". Jau 1930. gada 10. februāra korporācijas sapulcē tika pieškirirtas pirmās regālijas "Veidolas" dibinātājām (LNA LVVA, 50341-3, 1. 1p.).

Biedrības-korporācijas mērkiis bija apvienot nacionāli domājošas LMA audzēknes biedrībā (korporācijā) nacionālās mākslas un pašizglītības veicināšanai un attīstīt viņās individuālā goda apziņu, atbalstīt savas biedrenes materiāli un morāli, kā arī izkopt nacionālo apziṇu un izveidot sabiedriskam darbam spējīgas darbinieces (LNA LVVA, 5034-1-1, 1. lp.). Biedrībaskorporācijas devīze bija "Darbam, patiesībai, saskan,ai”, bet krāsas - melns, sudrabs, sarkans. Sākotnēji kā biedreņu ārējās pazī̌anas atribūtika tika noteikta arī melna samta berete, kurai labajā pusē iestrādātas krāsas melnssudrabs-sarkans, krūšu lente, balts krekliņš garām piedurknēm, melns samta ņieburs, melni brunči (LNA LVVA, 5034-1-1, 1.-2. lp.)

Savā iekšējā dzīvē veidolas nodevās literārajiem vakariem pirmdienu vakaros vidēji divas reizes mēnesī, kuros vin,as uzstājās ar referātiem, veltîtiem dažādiem mākslas jautājumiem. Vakari tika rīkoti vai nu veidolu lokā, vai kopā ar goda filistriem. 1930. gada novembrī par "Veidolas" goda filistriem tika uzņemti Vilhelms Purvītis, Pēteris Feders un Rihards Zarinšs (LNA LVVA, 5034-1-3, 11. lp.). Vērojami arī kopīgi literārie vakari ar "Dzintarzemes" kungiem (3. attēls). No visām akadēmiskajām studentu organizācijām "Veidolai” ar "Dzintarzemi” bijušas visdraudzīgākās attiecības. Ar dzintarzemiešiem veidolas kopīgi darbojušās arī LMA studentu dzīvē, aktīvi piedaloties gan LMA padomes vēlēšanās, gan ikgadējā LMA karnevāla rīkošanā. Bez literārajiem vakariem veidolu iekšējās dzīves neatn,emama sastāvdaḷa bija arī tematiskie zīmēšanas vakari. Dažreiz zīmēšanas vakari notika kopā ar kādu goda filistru vai LMA mācībspēku. Arī radošiem mājasdarbiem bija būtiska nozīme, piemēram, 1931. gada februārī par godu gaidāmajam karnevālam katrai veidolai uz nākamo tikšanās reizi bija jāuzzīmē žurnāla "Atpūta" vāks par tēmu "Karnevāls" (LNA LVVA, 5034-1-3, 18. lp.). Lai tiektos uz augstākiem rezultātiem un atzinību, tāpat kā dzintarzemieši, arī veidolas centās rīkot savas personalizētās iekšējās un publiskās izstādes nelielam skatītāju lokam. Vērtīga pieredze bija arī citu izstāžu aktīva kolektīvā apmeklēšana un diskusijas. 


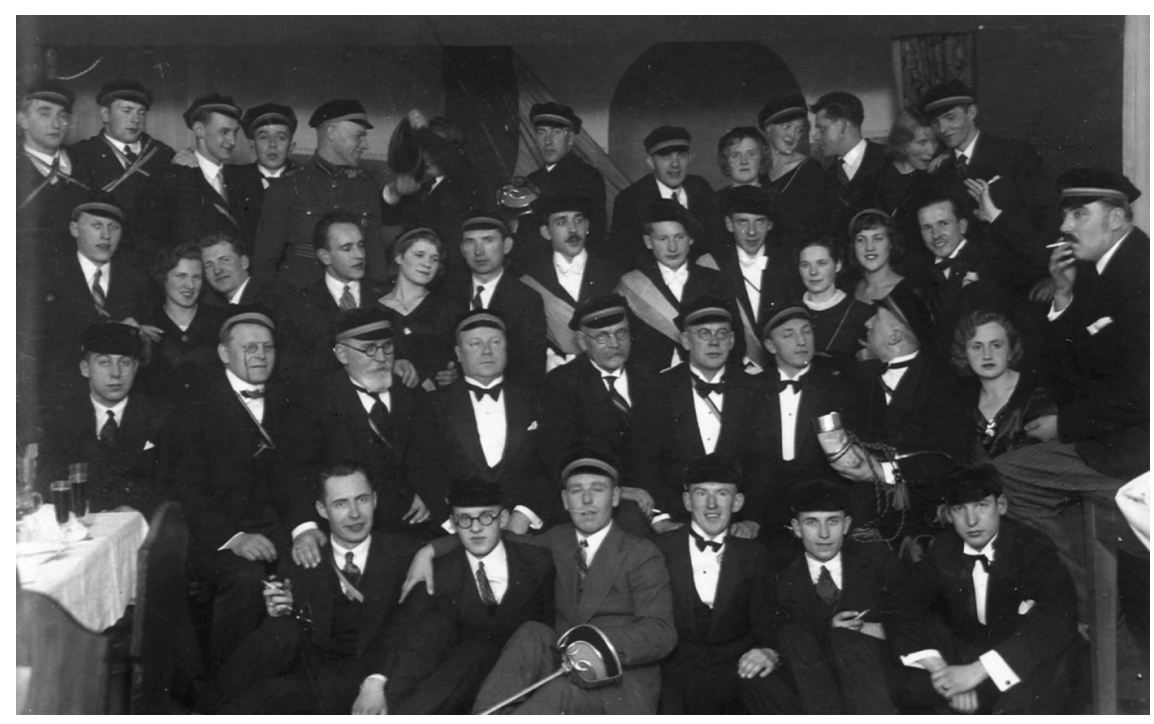

3. attēls. Latvijas Mākslas akadēmijas studentu korporācijas "Dzintarzeme" un studenšu korporācijas "Veidola" (1928-1940) viesu vakars 1931. gada decembrī. Labajā pusē trešajā rindā ar cigareti mutē stāv "Dzintarzemes" goda filistrs Kārlis Miesnieks. No Cēsu Vēstures un mākslas muzeja krājuma (CM 115744).

Lai gan veidolas centās pilnveidot un attīstìt savu darbību, biedrenes pastāvīgi saskārās ar birokrātiskiem šḳēršliem valsts institūcijās, kas bija iemesls drīzai "Veidolas" likvidācijai. 1929. gada martā veidolas vērsās Latvijas Republikas Izglìtības ministrijā ar lūgumu apstiprināt "Veidolas" biedreņu atsevišķās krāsu nozīmes (LNA LVVA, 5034-1-1, 10. lp). Aprīīi pienāca ziṇa, ka iesniegtais lūgums aț̣aut lietot dalībnieču ārējās pazišanas atribūtiku pēc iesniegtajiem paraugu zīmējumiem tika bez pamatojuma noraidìts, izn,emot melna samta n,ieburu, pret kura valkāšanu iebildumu nebija (LNA LVVA, 5034-1-1, 11. lp). 1931. gadā, mēgininot rast kompromisu, Izglìtības ministrija veidolām aț̣āva lietot ārējās nozīmes divās krāsās (sudraba un sarkanā), taču viņas turpinājušas lietot trīs krāsas, par ko liecina Izglìtības ministrijas izteiktais aizrādījums, ka, par spīti ațaujai lietot divas krāsas, veidolas neatḷauti izmantojušas trīs krāsas. Izglīīības ministrija aizrādīja, ka tām nav tiesības lietot neatḷautas, respektīvi, nereǵistrētas, ārējās nozīmes, pretējā gadījumā ministrija būs spiesta saukt organizācijas vadību un vainīgās personas pie atbildības (LNA LVVA, 5034-1-1, 12. 1p). 1933. gadā veidolas aktīvi cīnijjās, vēršoties gan pie Izglīīibas ministrijas, gan Iekšlietu ministrijas preses un biedrību nodalas, bet vēlamais netika sasniegts. Kā alternatīvu, lai aț̣autu nēsāt krāsas un nozīmes, 1933. gadā veidolas Izglīitības ministrijai piedāvāja "Veidolu" dēvēt nevis par korporāciju, bet par sieviešu biedrību (LNA LVVA, 5034-1-1, 23. lp). Krāsu neapstiprināšanas dēḷ "Veidola" pārorganizējās no korporācijas uz biedrību un uz 
laiku nolēma pat pārtraukt darbību biedreņu mazā skaita dēḷ. Birokrātiskās problēmas atspoguḷjojas arī "Veidolas" organizācijas definējumā "biedrībakorporācija". Lai gan savā iekšējā organizācijas kārtībā tā bija korporācija, valsts institūcijās tā tika reǵistrēta kā biedrība, tāpēc avotos dominē dubultapzīmējums. Liktenīgs organizācijai bija 1936. gads, kad Iekšlietu ministrija konstatēja, ka biedrībai no četriem valdes locekḷiem palikuši tikai divi, tāpēc 1936. gada 3. jūnijā tā uzdeva "Veidolas" valdei likvidēt biedrību (Valdības Vēstnesis 1936, 3). Pēdējā "Veidolas" sēde noturēta 1936. gada 23. jūlijā ar darba kārtību "Biedrības likvidēšana" (LNA LVVA, 5034-1-2, 17.-19. 1p.).

\section{VIENOTNE "ZAL̄Ā ZEME"}

Vienotne "Zaḷā zeme" ar Rīgas apgabaltiesas lēmumu reǵistrēta 1933. gada 19. decembrī (Valdības Vēstnesis 1934, 2). Tā bija radniecīga organizācija Latvijas Universitātes studentu vienotnēm. Radot laika garam un latvietībai piemērotas tradīcijas, tā atmeta novecojušās un no svešām organizācijām aizṇemtās tradīcijas un neuzturēja kontaktu ne ar dzintarzemiešiem, ne veidolām. Vienotnes "Zaḷā zeme" pamatā tika likti pieci centieni: māksla, darbs, skaidrība, brīvība, tēvu zeme, tās devīze bija "Esi uzticīgs mākslai kā savam Dievam, esi uzticīgs zemei un laikam, kurā tu dzīvo!", bet krāsas bija sūnzaḷš un zelts (Students 1934, 1). "Zaḷā zeme" pulcēja gan LMA audzēkņus, gan arī brīvklausītājus, lai kopējiem spēkiem noskaidrotu mākslas problēmas, idejiskos ceḷus un nodibinātu kā kopējo, tā individuālo māksliniecisko pasaules uzskatu. "Zaḷās Zemes" biedriem bija aizliegts iestāties citās mākslinieku biedrībās par aktīviem biedriem (LNA LVVA, 1969-1-20, 27. 1p.).

Sekojot laika garam un jauniem virzieniem mākslā, vienotne negribēja balstīties uz kādām dogmām vai teorijām, kas traucētu individuālo attīstību. Vienotnes ideoloǵija pauda brīvu individuālo spēju sacensību. Zaḷzemieši aktīvi uzturēja sakarus ar vecāko paaudžu māksliniekiem, veidoja tālāk un paplašināja viṇu sāktās latviskās mākslas tradīcijas, izskaužot diletantismu pašu starpā un sabiedrībā. Vienotnei kā vecbiedri l,oti tuvu stāvēja mākslinieki Valdemārs Tone un Konrāds Ubāns, un labu glezniecības skolu vienotnes biedri guva prof. Purvīša darbnīcā (Students 1934, 2). Visas apgūtās prasmes un izaugsmi zaļzemieši centās parādīt izstādēs. Vienotnei it sevišḳi bija raksturīgas slēgtās izstādes, lai paši varētu analizēt un izteikt kritiku cits citam, tādējādi pilnveidojoties, jo cīṇa ar diletantismu bija viens no svarīgākajiem virzītājspēkiem. Publiskās izstādes lielākoties tika rīkotas šauram apmeklētāju lokam, parasti LU sadraudzības organizāciju telpās, piemēram, vienotṇu "Līdums" vai “Ausma" telpās, vai arī izbraukuma 
izstādēs citās Latvijas pilsētās, tuvinot savai mākslai citus apmeklētājus un dodot iespēju tiem sekot zaļzemiešu attīstībai. Ar izbraukuma izstādēm zaḷzemieši centās uzturēt pastāvīgu komunikāciju ar sabiedrību, gūt ierosmi radošam darbam, novērst mākslas izolāciju savā tautā un sniegt padziḷinātu mākslas izpratni sabiedrībā - pasniegt mākslu nevis kā lieku greznību, bet kā nepieciešamību. Līdz 1939. gadam tikušas sarīkotas ap astoņām publiskajām izstādēm (Latvijas Kareivis 1939, 2).

Bez izstādēm zalızemiešiem bija raksturīgas arī Sirmās stundas jeb literārie vakari par latviešu un ārzemju glezniecības jautājumiem, gleznotājiem, izstāžu kritiku. Tika organizēti arī mākslinieku nāves dienu atceres pasākumi, kopīgas ekskursijas uz gleznu izstādēm kopā ar Latvijas Universitātes akadēmiskajām vienībām "Ausma", "Latviete", "Līdums". Vienotnei audzinot savā starpā kopības un pienākuma apziṇu, zaḷzemieši gribēja rast saskarsmi arī citām organizācijām, nodibinot pastāvīgas, labas attiecības un pēc iespējas vairāk sadarbojoties kopēju mērḳu un konkrētu darbu virzienā, sevišķu vērību pievēršot tieši studentu aprindām, it īpaši vienotnēm. Tāpēc zaļzemieši ḷoti satuvinājās ar minētajām vienībām "Ausma", "Latviete" un "Līdums". Kopā tika rīkoti dažādi pasākumi - dzejnieku pēcpusdienas, darba svētki, Mārtiņu ķekatas u. c. Šì draudzība rezultējās ar to, ka 1936. gadā "Zạ̣ā zeme" noslēdza draudzības līgumu ar LU studentu vienotņu savienību "Vienkopas", kā arī iestājās latviešu-lietuviešu tuvināšanās biedrības akadēmiskajā sekcijā (LNA LVVA, 1969-1-20, 30. lp.). Raksturīgi vienotṇu sabiedrībā bija arī Augstie svētki, kas izpaudās kā uzstāšanās ar referātiem, izbraukumi, lai attīstìtu lauku ļaudīs daiļuma izpratni. Augsto svētku laikā zaļzemieši savā starpā aktīvi rosināja dažādas projektu idejas, kas sniegtu māksliniecisku ieguldījumu provincēs, piemēram, uzdāvinot kādai lauku vai pilsētas biedrības bibliotēkai albumu par Latvijas mākslu, māksliniekiem, to reprodukcijām un biogrāfijām, kādai lauku biedrībai vai skolai uzgleznojot telpās dekorācijas, atstājot no katra vienotņa kādu darbu, kādai draudzei uzgleznojot un dāvājot altārgleznu. Lai gan studentu korporāciju "Dzintarzeme" varam uzskatīt kā lielāko LMA korporāciju, vienotnes "Zaḷā zeme" loma mākslinieciskajās aktivitātēs vērojama kā izteikti fundamentālāka. Tas skaidrojams ar to, ka tā nepiešķīra tik ḷoti lielu nozīmi iekšējai organizācijas reglamentācijai un tradīcijām, kā tas bija korporācijām, bet gan ìstenoja ideoloǵiju, kas bija vērsta uz biedru profesionālo izaugsmi.

\section{SECINĀJUMI}

LMA akadēmisko studentu organizāciju loma jauno mākslinieku izaugsmē un profesionālās izaugsmes veicināšanā starpkaru posmā vērtējama kā nozīmīga vairākos aspektos. Pirmkārt, LMA studentu organizācijas, lai 
gan tām bija atšķirīga ideoloǵija, vienoja vienots mērkis - pilnveidot savus biedrus intelektuāli, disciplinēt un sagatavot kā konkurētspējīgus māksliniekus. Atšķirībā no citām Latvijas akadēmiskajām organizācijām, LMA studentu organizācijas bija vienīgās, kuras līdztekus studijām rosināja savus biedrus un palīdzēja viņiem attīstìt mākslinieciskās prasmes profesionālā jomā. Studentu prasmes tika attīstītas gan literārajos vakaros, mākslas nodarbībās, izstāžu apmeklējumos, izstāžu organizēšanā, gan citās aktivitātēs. Otrkārt, jaunos māksliniekus atbalstīja arī latviešu mākslas vecmeistari un mācībspēki, kuri kḷuva par organizāciju filistriem/vecdraugiem, lai aktīvi līdzdarbotos organizāciju dzīvē. Treškārt, nozīmīgs aspekts bija arī biedru materiālais un morālais atbalsts, ko sniedza LMA akadēmiskās organizācijas. Ceturtkārt, būtiska nozīme biedru izaugsmē bija organizāaiju vēlmei pastāvēt pašām par sevi, tādējādi popularizējot savas organizācijas un tās biedru vārdus, - organizācijas reti piedalījās LMA audzēkṇu kopējās izstādēs, tās centās nebūt citās mākslinieku biedrībās. Tās organizēja savas individuālās izstādes, lai popularizētu savu organizāciju un tās biedrus. Vienotne "Zaḷā zeme" vērtējama kā visaktīvākā LMA studentu organizācija (aktīva izstāžu organizēšana, augstas mākslinieciskās prasības jaunajiem māksliniekiem). Dzintarzemiešu darbības priekšplānā vispirms bija korporācijas iekšèjās tradīcijas, reglamenti un stingra to izpilde un tikai pēc tam mākslinieciskā jaunrade.

LMA akadēmisko studentu organizāciju nozīme vērojama arī akadēmiskajā vidē un sabiedrībā. Pirmkārt, LMA studentu organizācijas vērtējamas kā dạ̣a no nacionālās latviešu akadēmiskās vides veidotājām un latviešu vecmeistaru māksliniecisko ideju mantotājām un popularizētājām. Nozīmīgs aspekts ir tas, ka visas trīs LMA studentu organizācijas - studentu korporācija "Dzintarzeme", korporācija-biedrība "Veidola" un vienotne "Zạā zeme" - pārstāvēja latviešu nacionālo mākslu, Vilhelma Purviša skolu, ko ne tikai izkopa savā starpā, bet arī popularizēja ārpus organizācijām un LMA. Minams ir arī sabiedriskais labums, ko nesusi vienotne "Zạ̣ā zeme" un kas izpaudās gan kā Augsto svētku projekti, gan Latvijas provinču tuvināšana mākslas pasaulei. Ar savu izstāžu rīkošanu studentu korporācija "Dzintarzeme", studenšu korporācija-biedrība "Veidola" un vienotne "Zą̧ā zeme" spēja popularizēt gan sevi, gan LMA un veicināt līdzcilvēku saskarsmi ar Latvijas starpkaru perioda vienu no lielākajiem kultūras mantojumiem - latviešu nacionālo mākslu.

\section{SAITSINĀJUMI}

AAL - Art Academy of Latvia

CM - Cēsu muzejs

LMA - Latvijas Mākslas akadēmija 
LNA - Latvijas Nacionālais arhīvs

LVA - Latvijas Valsts arhīvs

LVVA - Latvijas Valsts vēstures arhīvs

\section{IZMANTOTIE AVOTI UN LITERATŪRA}

\section{AVOTI}

A. J., 1939. Latvijas Mākslas akadēmijas 20 gadi. Latvijas Kareivis, Nr. 281, 2.

Audriņš, J., 1973. Dailei, draugam, Dzintarzemei. Laiks, Nr. 21, 3.

Auls, E., 1960. Kas ir studentu vienības? Akadēmiskā Dzìve, Nr. 3, 69-70.

Dailei, darbam, Dzintarzemei, 1958. Latvija Amerikā, Nr. 94, 5.

Dzintarzemes 35 gadi, 1958. Laiks, Nr. 94, 3.

Intīmā L. m. akadēmijas vienotnes "Zaḷā zeme" izstāde, 1934. Students, Nr. 214, 2.

Jaunās Mākslas akadēmijas audzēkṇu studentu vienotnes centieni un mērḳi, 1934, Students, Nr. 209, 1.

Studenšu biedrības-korporācijas "Veidola" sēžu protokoli, 1929-1936. LNA LVVA, 5034-1-3, 1., 11., 18. 1p.

Studenšu biedrības-korporācijas "Veidola" sēžu protokoli, 1929-1936. LNA LVVA, 5034-1-2, 17.-19. lp.

Studenšu biedrības-korporācijas "Veidola" statūti, biedrus sapulču protokoli, ārējo nozìmju paraugi, sarakste, 1929. LNA LVVA, 5034-1-1, 1.-23. lp.

Studentu korporācijas "Dzintarzeme" dibināšanas sapulces, valdes sēžu un biedru sapulču protokoli, 1924-1940. Latvijas Nacionālais arhīvs - Latvijas Valsts arhìvs (Rīga, turpmāk: LNA LVVA), 2477-1-2, 1. lp.

Studentu korporācijas "Dzintarzeme" ienākošie raksti, 1932./33. g. LNA LVVA, 2477-1-12.

Studentu korporācijas "Dzintarzeme" sēžu protokoli, 1924-1940. LNA LVVA, 2477-1-6, 4. lp.

Studentu korporācijas "Dzintarzeme" statūtu un iekšējās kārtības noteikumu noraksts, Latvijas Nacionālais arhìvs - Latvijas Valsts arhìvs (Rīga, turpmāk: LNA LVVA), 2061-1-1, 1.-13. lp.

Tiesu sludinājumi, 1929. Valdỉbas Vēstnesis, Nr. 65, 6.

Tiesu sludinājumi, 1934. Valdïbas Vēstnesis, Nr. 221, 2.

Valdības rīkojumi un pavēles, 1936. Valdïbas Vēstnesis, Nr. 125, 3.

Vienotnes "Zaḷā Zeme” protokoli, 1934-1940. LNA LVVA, 1969-1-20, 27., 30. 1p.

Z., 1929. Latvijas Mākslas akadēmija. Students, Nr. 148, 2.

10 gadu jubileja, 1933. Latvis, Nr. 3464, 3.

\section{LITERATŪRA}

Ščerbinskis, V., 2010. Uzticīgi draugam, Latvijas studējošo slēgtās mūža organizācijas. Rìga: Prezidiju konvents, 167. 


\title{
ACADEMIC STUDENT ORGANISATIONS OF THE ART ACADEMY OF LATVIA (1923-1940): THEIR ROLE IN SOCIETY AND IN THE PROFESSIONAL DEVELOPMENT OF YOUNG ARTISTS
}

\author{
AGNIJA LESNIČENOKA \\ MA in History \\ Art Academy of Latvia \\ Email: aruhocka@inbox.lu
}

\begin{abstract}
After the proclamation of the Republic of Latvia in 1918 the country experienced a rapid flow of youth into the capital city Riga with the aim of obtaining higher education. Students, along with their studies, began to develop their academic youth's life. In the period under discussion the students of the Art Academy of Latvia (AAL) also began to look for ways to set up their own organisations. In 1923 the AAL students founded their first organisation - student fraternity "Dzintarzeme" [Amberland]. In 1929 student sorority "Veidola" was established, followed in 1933 by student association "Zaḷā zeme" [The Green Land]. The aim of the paper is to find out the role of the academic student organisations of AAL in the professional development of their members and in the academic environment, as well as in the society of Latvia in general.
\end{abstract}

Keywords: Latvian Academy of Arts, student organisations, $20^{\text {th }}$ century, the interwar period.

\section{SUMMARY}

In the interwar period, the founding of AAL student organisations was more specific than that of other Latvian student corporations or associations. Until then, neither in Latvia nor in Tartu, Estonia, there had been any academic student organisation of Latvian artists. The specific circumstances required new, adequate forms and traditions that had to be created anew.

"Dzintarzeme" [Amberland] (1923-1940) was ideologically influenced by German fraternities. The aim of "Amberland" was to unite nationallyminded students of the Art Academy of Latvia for the promotion of national 
art and self-education. The members held literary evenings dedicated to art and literature. The list of activities also included criticism of exhibitions. The members held private and public art exhibitions as an opportunity for improving their artistic skills, popularizing themselves and selling their paintings. The members of "Amberland" inclined towards the old masters and Latvian art.

The aim and ideology of sorority "Veidola" (1929-1936) was very similar to those of "Amberland". For the members of this organisation, too, the promotion of national art and self-education, as well as the provision of mutual material and moral support were important goals. Apart from literary evenings, thematic drawing evenings also were an integral part of the life of "Veidola" members.

"Zaḷā zeme" [The Green Land] (1933-1940) was a kindred organisation to student unions of the University of Latvia. It rejected old-fashioned traditions borrowed from foreign organisations and did not maintain any contacts either with the members of "Amberland" or "Veidola". The members of "The Green Land" actively upheld contacts with the older generation of artists, developed further and expanded the traditions of Latvian art that they had started. The members of the organisation tried to eliminate dilettantism in their own circles and in society in general. They tried to demonstrate their skills and achieved growth in private and public art exhibitions. Through public exhibitions they tried to keep in touch with society in order to get inspiration for their creative work, to prevent national isolation of art, to deepen the public perception of art not as a redundant luxury, but as a necessity.

The role of AAL academic student organisations in the growth of young artists during the interwar period is significant. AAL student organisations, although different in their ideology, were united in the aim of perfecting their members intellectually, disciplining and preparing them as competitive artists. Young artists were also supported by Latvian old masters of art and AAL teachers who became honorary members (called 'old friends') of these organisations. An important aspect was the mutual material and moral support of the members of the academic student organisations of AAL. AAL academic student organisations also played an important role in the academic environment and in society in general. AAL academic student organisations should be seen as part of the national academic environment in Latvia. An important aspect worth mentioning is that all three AAL academic student organisations - fraternity "Amberland", sorority "Veidola" and student association "The Green Land" - represented and adhered to the Latvian national school of art and Vilhelms Purvitis' School that the members cultivated not only in their own circles but also promoted outside their organisations and the AAL. 


\title{
LATVIJAS DZĪVNIEKU AIZSARDZĪBAS BIEDRĪBAS DARBĪBA (1935-1940)
}

\author{
MĀRTIN̦Š DĀTAVS \\ Mg. hist. \\ E-pasts: martins.dataus@gmail.com
}

\begin{abstract}
ANOTĀCIJA
Pētījumā atspoguḷota un analizēta Latvijas dzīvnieku aizsardzības biedrības attīstība un galvenie darbības virzieni no biedrības reorganizācijas brīža 1935. gadā līdz tās likvidācijai 1940. gadā. Šajā laikā par tās svarīgāko uzdevumu bija kḷuvusi cietsirdīgas izturēšanās pret dzīvniekiem izskaušana sabiedrībā un palīdzības sniegšana nelaimē nokḷuvušiem dzīvniekiem. Lai to īstenotu, biedrība panāca dažādu dzīvnieku aizsardzības likumu pieṇemšanu, uzturēja veterināro ambulanci un vienīgo Rīgas dzīvnieku patversmi, kā arī ar dažādiem publiskiem pasākumiem un literatūras izdošanu izglītoja sabiedrību dzīvnieku aizsardzības jautājumos.
\end{abstract}

Atslēgas vārdi: dzīvnieku aizsardzība, nevalstiskās organizācijas.

\section{IEVADS}

Līdz ar 19. gadsimta sākumu Eiropā plašāku popularitāti sāka iegūt dažādas idejas par cilvēcisku apiešanos ar dzīvniekiem. To popularizēšanas un realizācijas nolūkā tika dibinātas vairākas sabiedriskas organizācijas arī Rīgā, kur 1861. gadā tika nodibināta "Rīgas biedrība pret dzīvnieku mocīšanu"1, kas kḷuva par pirmo šāda tipa organizāciju Krievijas impērijā. ${ }^{2}$ Biedrība laika gaitā vairākkārt mainīja savu nosaukumu, kā arī pēc tās biedru savstarpējām domstarpībām 1887. gadā sašḳēlās, izveidojot divas patstāvīgas biedrības. Viena no tām bija "Rīgas dzīvnieku patversmes dāmu komiteja", kura kā vienīgā no abām biedrībām bija spējusi pārdzīvot Pirmo pasaules karu un atsākt savu darbību jau neatkarīgā Latvijā. 


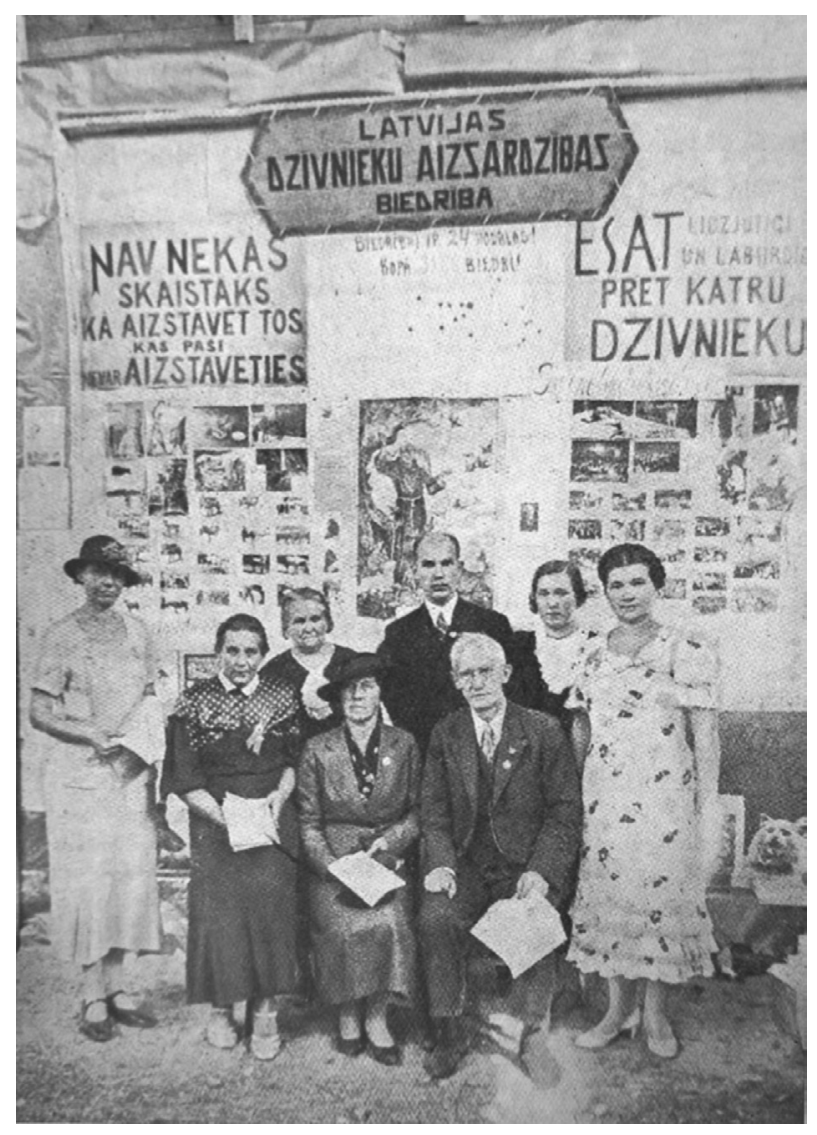

1. attēls. Latvijas dzīvnieku aizsardzības biedrības biedri Zemgales apgabala lauksaimniecības izstādes un plaujas svētkos Jelgavā 1937. gada augusta beigās / septembra sākumā (Ēkis, A., 1937. Esat līdzjūtīgi un labsirdīgi pret katru dzivnieku! Latvijas dzivnieku draugs, 3, 63).

Komitejas valdes priekšsēdētājas vācbaltietes Zigrīdas Pētersones patstāvīgā rīkošanās ar biedrības līdzekḷiem un mantu, kā arī nespēja un nevēlēšanās sasniegt komitejas pirmskara perioda darbības līmeni sekmējās arī to, ka 18 biedrības biedri 1934. gada nogalē vērsās pie Latvijas valdības ar lūgumu biedrību pārorganizēt. ${ }^{4}$ Tas izrādījās veiksmīgs solis, un jau 1935. gada 9. janvārī Latvijas Republikas iekšlietu ministrs Vilis Gulbis izdeva rīkojumu, ar kuru tika atcelta biedrības valde. Pēc šī notikuma un jaunas, tikai no latviešiem sastāvošas valdes iecelšanas biedrībai tika izveidoti jauni statūti un tā ieguva Latvijas dzīvnieku aizsardzības biedrības (turpmāk LDAB) vārdu. Atbilstoši pastāvošajam laikmetam LDAB uzskatīja, ka cietsirdīga izturēšanās pret dzīvniekiem ir nekulturāla, nehumāna un atstājama cilvēces pagātnē. Humāna apiešanās ar dzīvniekiem tika uzskatīta par cilvēka morālās attīstības izaugsmes apliecinājumu, kurai savukārt ir ietekme uz vardarbības izskaušanu starp cilvēkiem. Neilgā laikā biedrība plaši aktivizēja darbu, izglītojot Latvijas sabiedrību dažādos ar dzīvnieku aizsardzību saistītos jautājumos, kā arī panākot redzamus rezultātus dzīvnieku aizsardzībā. 
Pētījumā atspoguḷota un analizēta LDAB attīstība un darbības galvenie virzieni no biedrības reorganizācijas brīža 1935. gadā līdz tās likvidācijai 1940. gadā. Darbā uzmanība tiek pievērsta arī tam, cik plašā mērogā un cik efektīvi LDAB bija izvērsusi aktivitātes savu mērḳu sasniegšanai. Darba tapšanā galvenokārt izmantoti avoti no Latvijas Nacionālā arhīva Latvijas Valsts vēstures arhīva 2327. fonda, kurā apkopota lielākā daḷa no LDAB darbības periodā tapušajiem materiāliem.

\section{BIEDRĪBAS DARBĪBA}

Lai gan LDAB saknes bija atrodamas jau 1861. gadā, biedrība iepriekšējās valdes nekompetentas rīcības dēḷ nevarēja lepoties ar senām tradīcijām un plaši izvērstu darbu. Biedrībai trūka ne tikai pieredzes bagātu biedru, bet arī finansiālo līdzekḷu. Tomēr šāda situācija nebija šḳērslis biedrības veiksmīgas darbības atjaunošanai.

Jau 1935. gada beigās biedrības budžets no gandrīz pilnīga līdzekḷu trūkuma bija pieaudzis līdz 11416 latiem5 $^{5}$ 1939. gadā sasniedzot jau 38180 latus. ${ }^{6}$ Šajā laikā biedrības kustamās un nekustamās mantas vērtība bija sasniegusi 44500 latus. $^{7}$ Biedrības budžeta bāze pārsvarā veidojās no biedru iemaksām, dzīvnieku patversmes un ambulances darbības, biedrības organizētajām izlozēm un kulturālu pasākumu ieejas kartēm, kā arī dažādu personu ziedojumiem. Viens no redzamākajiem šāda veida ziedotājiem bija Latvijas Valsts prezidents Kārlis Ulmanis, kurš 1939. gada beigās biedrībai

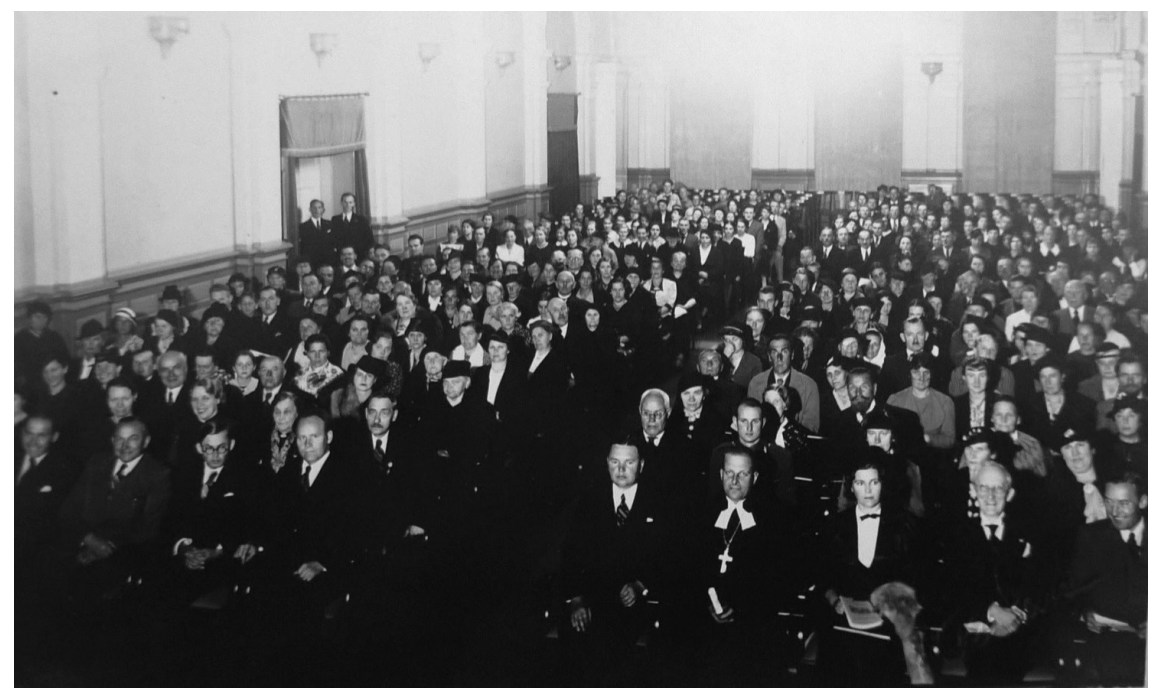

2. attēls. Ceturtās Latvijas dzīvnieku draugu dienas atklāšanas pasākums Latvijas Konservatorijas zālē 1938. gada 2. oktobrī (LNA LVVA, 2327-1-58, 1. 1p.). 
bija ziedojis 7000 latu. ${ }^{8}$ Arī citas sabiedrībā zināmas personas mēdza finansiāli atbalstīt LDAB darbību.

Lielākā biedrības budžeta daļa galvenokārt tika izmantota inspektoru un patversmes darbinieku algu izmaksai, dzīvnieku patversmes ēku remontam un tajā izmitināto dzīvnieku uztura nodrošināšanai, veterinārambulances un biroja uzturēšanai, kā arī citu ar biedrību saistītu mērḳu realizēšanai. Tā kā LDAB darbojās pēc biedru brīvprātīgā darba principa, tās valde par savu darbu atalgojumu nesañēma.

Biedrîbai bija izdevies arī tâs rindām piesaistìt jaunus biedrus. Tā 1937. gada beigās biedrībā bija iestājušies jau 3400 cilvēku, no kuriem 1240 biedru piederēja pie biedrības Rīgas nodal̦as. ${ }^{9}$ Biedrības rindās bija iestājušās vai ieceltas arī vairākas sabiedrībā zināmas personas. ${ }^{10}$ Taču piederība pie biedrības ne vienmēr nozīmēja augstu biedru aktivitāti biedrības ideju popularizēšanai. Tā biedrības pilnsapulcē 1939. gada 3. decembrī par biedru zemo aktivitāti sūdzējās kāds biedrības pārstāvis no Liepājas:

"Sekmīgu darbību traucē iedzīvotāju maza interese un izpratne, par mūsu biedrības mērḳiem un uzdevumiem. Tas neattiecas ne tikai uz pārējiem iedzīvotājiem, bet arī uz mūsu biedrības biedriem. Jo kā citādi to lai izskaidro, ja no 500 biedriem, uz uzaicināto sapulci ierodas tikai 40 . [..] Ir mēǵgināts sarīkot priekšlasījumu vakarus. Bet arī šie sarīkojumi ir vāji apmeklēti."11

Aktivitātes trūkums izpaudās arī citās nodaḷās, kuru darbības atdzìināšanai nereti tika rīkoti dažāadi sarīkojumi un izlozes. Biedrības aktivitāšu paplašināšanai bija ieplānota plašāku kontaktu uzturēšana ar Lietuvas, Igaunijas, Dānijas, Zviedrijas, Somijas biedrībām, kuru starpā idejas līmenī tika plānota Baltijas dzīvnieku aizsardzības biroja dibināšana. ${ }^{12}$ LDAB visā Latvijas teritorijā līdz 1940. gadam bija izveidojusi 19 nodalas. ${ }^{13}$ Jaunu nodalı dibināšana bija paredzēta arī nākotnē, taču šiem plāniem nebija lemts piepildīties Latvijas okupācijas dēḷ.

Par vienu no svarīgākajiem LDAB darbības virzieniem bija kḷuvusi tādu likumu pieņemšana, kas maksimāli aizsargātu dzīnniekus no cietsirdīgas izturēšanās pret tiem. Vēlākais biedrības uzdevums bija panākt to, lai sabiedrībā šie likumi tiktu arī ievēroti.

Pirmie likumi jeb "Obligatoriskie noteikumi lopu aizsargāšanai pret mocīšanu un bargu apiešanos" Latvijā tika pieņemti 1923. gada 5. decembrī. To redakcija tika balstīta uz Krievijas impērijas dzīvnieku aizsardzības noteikumiem, kuri, pēc LDAB uzskatiem, bija novecojuši. Lai šo situāciju labotu, biedrība jau 1935. gada beigās izstrādāja un iesniedza apstiprināšanai Zemkopības ministrijai un Iekšlietu ministrijai jaunu dzīvnieku aizsardzības noteikumu redakciju, kura tika apstiprināta 1936. gada 12. februārī. ${ }^{14}$ Šie noteikumi atkārtoti tika grozīti 1938. gadā. Līdzīgā veidā pēc LDAB lūguma Dzelzceḷa virsvalde 1939. gadā izdeva noteikumus, kas noteica kārtību 
dzīvnieku transportēšanai pa dzelzceḷu, tā uzlabojot to transportēšanas apstākḷus.

Lai sekmētu dzīvnieku aizsardzības noteikumu ievērošanu, biedrības biedri apsekoja publiskas vietas, piemēram, tirgus, kā arī reaǵēja uz iedzīvotāju iesūtītajiem ziņojumiem par iespējamiem cietsirdības gadījumiem pret dzīvniekiem. ${ }^{15}$ Atklātos cietsirdības pret dzīvniekiem gadījumos tie vainīgajām personām izteica brīdinājumu vai par to ziņoja policijai. Daudz aktīvāk šos pienākumus uzņēmās divi speciāli algoti inspektori, kuru darbība bija izvērsta arī vietās, kurās LDAB nebija nodibinājusi savas nodaḷas. Inspektoru darbs nereti bija arī bīstams. Tā 1936. gada 14. jūlijā tika piekauts biedrības aǵents Nikolajs Ivanovs, kurš Šampētera ielā Rīgā aizrādījis orman,iem par pārāk smagu vezumu uzkraušanu zirgam. Trīs uzbrucēji ne tikai salauza aǵenta brilles, bet arī saplēsa tā pierakstus. ${ }^{16}$

Par problemātisku nereti kḷuva atsevišksu policijas darbinieku attieksme un savu pienākumu nezināšana, viṇi bieži atteicās sodīt personas par cietsirdīgu izturēšanos pret dzīvniekiem vai arī nepievērsa tam uzmanību. Tā 1936. gada 6. jūlijā Rundālē LDAB Jelgavas nodal̦as valdes locekle Ženija Vanaga kopā ar Jelgavas veterinārārstu Otti vietējā gadatirgū pārbaudīja, vai netiek pārkāpti dzīvnieku aizsardzības likumi. Tika konstatēts, ka kāda ebreju tirgoṇa Jān,a Feuges zirgs bijis tik novārdzis, ka nav spējis piecelties kājās. Veterinārārsts atzinis, ka zirgs uz vietas ir nošaujams:

“[..] Pēc ārsta un biedrības locekḷa atzinuma, zirgs bij uz vietas jānošauj, bet tirgū dežūrējošie policijas kārtībnieki neațāavuši nošaut. [..] Ieradies kāds policijas ierēdnis, it kā no Bauskas, [..] Arī tas neḷāvis zirgu nošaut, bet atdevis īpašniekam, lai tas dzen viņu atpakal uz Talsiem un teicis, ka gan jau īpašnieks pats viṇu nošaušot. [..] Biedrības locekḷiem vairs nav bijis pie kā griezties pēc palīdzības, jo policijas ierēdnis atstāja nabaga lopu mežonīgo žīdu rīcībā." 17

Biedrībai bija arī pozitīva pieredze ar policijas darbu, kuras darbinieki nereti iniciatīvu par dzīvnieku aizsardzības noteikumu ievērošanu uzṇēmās bez lieka biedrības aicinājuma. Lai motivētu policistus darboties vēl aktīvāk, reizi gadā Vispasaules dzīvnieku aizsardzības dienā 4. oktobrīin biedrība ar dažādām balvām un goda rakstiem apbalvoja policistus, kuri bija sarakstījuši visvairāk protokolu par cietsirdīgu apiešanos ar dzīvniekiem.

Ja aplūko statistiku, tad tikai Rīgā 1935. gadā sarakstīti 310 šādi protokoli. Līdz 1936. gada 31. jūlijam šis skaitlis bija palielinājies jau līdz 430 uzrakstītiem protokoliem. Līdzīgā daudzumā protokoli tika izrakstīti arī Latvijas provincēs. Vairāk nekā 90\% minēto protokolu saṇēmēju tika sodìti ar naudas sodu no 10 līdz 75 latiem vai arī ar arestu no 3 dienām līdz 1 mēnesim. ${ }^{19}$ Izrakstīto protokolu skaits varētu būt bijis vēl lielāks, taču dzīvnieku aizsardzības noteikumu pārkāpējiem nereti izteica tikai mutisku brīdinājumu, kas saistīts ar minēto noteikumu nezināšanu vai neuzmanīgu 
rīcību, piemēram, par to, ka zirgam liek vilkt pārāk smagu vezumu. Biedrībai bija tiesības anulēt arī ormaņu licences. LDAB rīcības rezultātā tika sodīti vairāki noteikumu pārkāpēji, bet biedrības valde uzskatija, ka piemērotie sodi ir pārāk mazi. Tā uzskatīja, ka nepieciešams sekot Rietumeiropas valstu sodu sistēmai, piemēram, Vācijai, kurā par cietsirdīgu apiešanos ar dzīvniekiem piespriestais sods varēja būt līdz pat 10000 marku vai cietumsods no 6 mēnešiem līdz 2 gadiem. ${ }^{20}$ Šãdi biedrības uzskati palika tikai idejas lìmenī.

Lai gan LDAB iestājās par visu dzīvnieku aizsardzību, svarīga nozīme biedrības darbībā bija tieši zirgu aizsardzībai, kas īpaši tika uzsvērta vairākos dzīvnieku aizsardzības noteikumu punktos. Šāda nostāja saistāma ar faktu, ka tolaik zirgi bija visbiežāk izmantotais transporta līdzeklis lauksaimniecībā. Šo faktu labi saprata arī LDAB un spēja to izmantot savā labā, argumentējot, ka cietsirdīga izturēšanās pret zirgiem ir ne tikai neētiska, bet arī pielīdzināma valsts ekonomisko resursu tīšai bojāšanai. Cietsirdība pret zirgiem visbiežāk izpaudās kā to nepilnvērtīga barošana, pārāk smaga vezuma uzkraušana, kā arī nepiemērotu pārvietošanās apstākḷu nodrošināšana. Tā svarīga bija saziņa ar dažādām valsts institūcijām par kvalitatīva un zirgiem piemērota ceḷu seguma nodrošināšanu. Vietās, kurās pastāvēja risks zirgiem savainoties, attiecīgai institūcijai tika lūgts ceḷu salabot. Kā viena no šādām vietām 1936. gadā pieminēta Daugavmala pie pilsētas kanāla iztekas, pie kuras regulāri ar grūtībām pārvietojas ne tikai zirgi, bet arī cilvēki. Šajā sakarā LDAB Jūrniecības departamenta Rīgas ostas vadībai ziņoja, ka "Šodien viens ekspeditors ziņoja, ka tajā neizbraucamajā vietā viṇam sakropḷots jau trešais zirgs. Zirgs jauns, maksājis Ls 900,- un tagad būšot jānošauj, jo sasviestajos akmeņos iegrimstot zirgs pārrāvis kājas dzīslu" "21.

Šādu sūdzību rakstīšana nereti bija visai sekmīga. Piemēram, LDAB Liepājas nodaḷai bija izdevies panākt pilsētas valdes lēmumu, kurā noteica: lai novērstu zirgu savainošanos rudens dubḷos un pavasara atkušņos, visās koku, malkas un og̣̣u sētās jābūt izbrug̣ētiem braucamiem celiem.

Savukārt par vienu no sarežğitākajiem jautājumiem biedrības darbībā kḷuva tādu dzīvnieku aizsardzības noteikumu panākšana, kas Latvijā liegtu dzīvniekus kaut pēc rituālās metodes. Šì problēma bija divējāda, proti, dzīvnieku apdullināšanai nepieciešamo iekārtu trūkums lopkautuvēs, kā arī ebreju minoritātes reliǵiskās vajadzības. Dzīvnieku apdullinošo iekārtu trūkumu biedrība, sākot ar 1939. gadu, plānoja atrisināt, ar šīm iekārtām nodrošinot lopkautuves, bet par sarežğîtāku jautājumu tika uzskatīta atbalsta gūšana ebreju rindās. LDAB valdes loceklis A. Eglītis šajā sakarā izvirzīja ideju:

"Vai nebūtu iespējams starp žĩdiem atrast inteliǵgentus cilvēkus, kuri atbalstītu mūs cīnāa ar šechtēšanu? Tiklīdz šis jautājums tiek pacelts no citu 
tautu puses, žĩdi to uzskata par rases naida izpaudumu, un rodas stipra pretkustība." 22

Šis jautājums izraisīja asas abu pušu diskusijas un līdz ar Latvijas okupācijas sākumu palika neatrisināts.

Viena no redzamākajām LDAB darbības izpausmēm bija tās vadītā dzīvnieku patversme un veterinārambulance, kura Rīgā, Ormaņu ielā 32, atradās jau kopš biedrības dibināšanas pirmsākumiem. Darbs patversmē noritēja visai intensīvi. Tā pusgada laikā, no 1935. gada sākuma līdz 1936. gada 31. jūlijam, patversmē bija pabijuši 3670 dažādi dzīvnieki, tostarp 180 zirgi. No šajā periodā patversmē uzn,emtajiem dzīvniekiem ambulatoriski tika iemidzināti 1050 dzīvnieki. ${ }^{23}$ Šāds patversmē pabijušo dzīvnieku skaits līdzīgos apjomos saglabājās arī turpmākos biedrības darbības gadus. Patversmes darbībā bija ieinteresēta arī Rīgas pilsētas valde, kura daḷēji sedza tās ēku remonta izmaksas, kā arī regulāri izsniedza malku patversmes telpu apkurei un hloroformu dzīvnieku iemidzināšanai. Šādi biedrība palīdzēja izskaust Rīgā klain,ojošo suņu un kaḳu problēmu. Tā 1936. gadā Rīgas pilsētas valde biedrības patversmei izsniegusi $72 \mathrm{~kg}$ hloroforma (jeb $6 \mathrm{~kg}$ mēnesī), kas tika uzskatīts par pārāk niecīgu atbalstu, un jau 1937. gadā šì daudzuma vietā tika pieprasīti $10 \mathrm{~kg}$ hloroforma. ${ }^{24}$ Turpmākajos gados pieprasītā hloroforma daudzums palielinājās.

LDAB uzturētā Rīgas dzīvnieku patversme šajā laikā bija modernākā šāda veida patversme Baltijā. ${ }^{25}$ Tā bija arī vienīgā dzīvnieku patversme Rīgā ar vienīgo veterināro ambulanci Pārdaugavā. Biedrība līdz savai likvidācijai organizēja patversmes arī Jelgavā, Daugavpilī, Rēzeknē un Liepājā un plānoja organizēt arī citās Latvijas pilsētās.

Biedrība plaši organizēja arī dažādas izlozes, informatīvus un kulturālus pasākumus. Šie pasākumi papildināja biedrības kasi un izglītoja sabiedrību jautājumos, kas saistīti ar dzīvnieku aizsardzību. Par vienu no plašākajiem šāda veida pasākumiem kḷuva Vispasaules dzīvnieku aizsardzības dienas atzīmēšana, kuru kā ikgadēju pasākumu LDAB aizsāka 1935. gada 6. oktobrī: ${ }^{26}$

"Vispasaules dzīvnieku draugu dienas uzdevums ir - pamodināt visas pasaules sabiedrības apziņu. Dzīvnieku aizsardzības jautājumā vispasaules apziņai tāpat jāmostas kā savā laikā tas notika, apkarojot cilvēku verdzību, meiteņu tirdzniecību, vai opija lietošanu. [..] Vispasaules dzīvnieku dienā notiek galvenā kārtā idejas propaganda. [..]"27

Visplašākie sarīkojumi tika organizēti Rīgā, bet mazākā apmērā - citviet Latvijā. Šajā laikā Rīgā ar lekcijām uzstājās Lielbritānijas sūtnis un pilnvarotais Latvijā Edmunds Džons Monsons un anglikāṇu baznīcas mācītājs Arturs Harisons. Visos sarīkojumos tika izplatīta literatūra un skrejlapas par dzīvnieku aizsardzības tematiku. Lai biedrības sludinātās idejas tiktu izplatītas vēl plašākās sabiedrības masās, LDAB priekšsēdētājas vietnieks 
Roberts Bāce Radiofona tiešajā ēterā nolasīja referātu par dzīvnieku aizsardzību. Sekojot biedrības izvirzìtajiem mērḳiem un īpašam Izglīīibas ministrijas rīkojumam, dažādi jautājumi par dzīvnieku aizsardzības nozīmi tika apspriesti arī vairākās Latvijas skolās. Aicinājumam atsaucās arī vairākas Latvijas kristiešu konfesijas, kuru mācītāji dievkalpojumu laikos cilvēkiem atgādināja par nepieciešamību ar cieņu izturēties pret dzīvniekiem. Šādā pašā garā Vispasaules dzīvnieku aizsardzības diena tika atzīmēta katru gadu, savu kulmināciju piedzīvojot 1936. gadā, kad šis dienas atzīmēšana tika apvienota ar biedrības 75. dibināšanas gadskārtu. Kopumā dažādi LDAB organizētie pasākumi bija kḷuvuši visai populāri, katru reizi kopā pulcinot apmēram 200-1000 cilvēku. ${ }^{28}$

Bez pasākumu organizēšanas LDAB izplatīja arī dažādus informatīvos materiālus, kuru izdošanai pat tika nodibināta neliela izdevniecība. LDAB darbības laikā tika izdoti 5 izdevumi par dzīvnieku aizsardzības jautājumiem un biedrības aktivitātēm. Tika publicētas arī divas bērnu pasakas: "Draugs draugam" un "Mātes sirds". No anglu valodas tās bija iztulkojis Kārlis Ulmanis, kurš finansiāli atbalstija to izdošanu. Biedrība dažādos Latvijas izdevumos aktīvi publicēja arī rakstus. ${ }^{29}$

Kā nerealizēts palika plāns par biedrības bibliotēkas un Informācijas centra izveidi, kurā bez attiecīgās literatūras būtu apskatāmas arī dažādas filmas par dzīvnieku humānu kaušanu, pareizu turēšanu un kopšanu. Tomēr biedrībai, īpaši to neplānojot, izdevās sava biroja telpās izveidot nelielu muzeju. Vienu no biroja sienām klāja dažādi plakāti un informācijas materiāli par labākajiem piemēriem dzīvnieku kopšanā un saudzēšanā, ar ko saskārusies biedrība, savukārt otru sienu klāja tādi paši materiāli, tikai par nežēlīgākajiem cietsirdības piemēriem pret dzīvniekiem. Biroja telpās bija aplūkojami arī dažādi priekšmeti, ar kuriem mocīti dzīvnieki. Biedrība arī bija izveidojusi vairāk nekā 100 diapozitīvu par dzīvnieku aizsardzību jaunatnes audzināšanai un prezentēja tos skolās, mazpulku, skautu un citās jaunatnes organizācijās, tā veicinot jaunatnes humāno audzināšanu. Pateicoties zemkopības ministra rīkojumam, 1939. gadā biedrība panāca to, ka visām lauksaimniecības skolām lopārstniecības kursos jānotur 3-5 stundu garas lekcijas dzīvnieku saudzēšanai. ${ }^{30}$

LDAB darbības beigu sākums pienāca līdz ar Latvijas okupāciju 1940. gada vasarā. Neskatoties uz pārmaiņām, biedrība turpināja darboties, kā arī tika pārdēvēta par Latvijas PSR dzīvnieku aizsardzības biedrību. Biedrībai tika iecelti jauni valdes locekḷi, kā arī noteikti jauni, padomju ideologiijai atbilstoši mērḳi. Jaunieceltās valdes pirmajā protokolā minēts: "Šis darbs sargā sociālistisko īpašumu, palīdz iesaistīt ražošanās iespējamās rezerves. [..] Pārkārtojot biedrības darbu, izskausts nevajadzīgais sentimentālisms un šis darbs piemērots praktiskām vajadzībām. [..] Dzīvnieku aizsardzības biedrība turpmāk izveidojama par Latvijas padomju 
sociālistiskās republikas saudzēšanas aktīvu, kurā apvienojami dzīvnieku saudzēšanas darbi, vetārsti, lopkopības instruktori, lopkopji, skolotāji un naturālisti - dzīvnieku draugi." 31

Līdz ar to dzīvnieku aizsardzība vairāk tika balstīta nevis uz ètiskiem principiem, bet gan ekonomiskām valsts vajadzībām. Tāpēc tādu ekonomiski neproduktīvo dzīvnieku kā kaķi vai suņi aizsardzība zaudēja nozīmi. Jaunā vara biedrībai uzlika arī jaunus pienākumus, kuros ietilpa par nelielu samaksu vai bez maksas veterināri apkopt trūcīgo iedzīvotāju dzīvniekus, iekḷaujot palīdzību to sagatavošanai ziemai. Lai gan šādus pienākumus varētu uzskatīt par pozitīviem, tas negatīvi ietekmēja biedrības tā jau izzūdošās finanses, kuru papildināšana ar biedru naudu iemaksām un pasākumu organizēšanu vairāk nebija iespējama. Trūkstošo līdzekḷu dēḷ biedrība vairs nevarēja saplānot savu 1941. gada budžetu. Tāpēc LDAB valde griezās pie Rīgas pilsētas pagaidu izpildes komitejas ar lūgumu sniegt pabalstu 20000 rubḷu apmērā patversmes un veterinārās ambulances nodrošināšanai. ${ }^{32}$ Tika piebilsts: ja šādu pabalstu pilsēta nevarētu sniegt, tad gan patversme, gan veterinārā ambulance nododama pilsētas pārvaldei, kā arī biedrības valde apñēmās turpināt iesākto darbu. Jau 1940. gada 12. decembrī ar LPSR Tautas komisāru padomes priekšsēdētāja Viḷa Lāča lēmumu Nr. 3555 biedrība tika likvidēta. ${ }^{33}$

\section{SECINĀJUMI}

Izvērtējot LDAB darbību tās pastāvēšanas 5 gados, var secināt, ka biedrība visai veiksmīgi pildīja savus uzdevumus un pakāpeniski tiecās sasniegt savu mērki. Tā, piemēram, līdz ar biedrības darbības izplešanos visā Latvijā praksē manāmi tika ierobežota cietsirdīga izturēšanās pret dzīvniekiem. Par to liecina kāda biedrības Valmieras nodaḷas biedra ziņojums 1939. gada 3. decembra biedrības nodalı kopsapulcē:

"Raksturot īsumā nodaḷas darbību, jāsaka, ka līdzšinējā nodaḷas darbībā ir vērojami panākumi. Kopš pastāv nodaḷa, nav vairs redzēti tik daudz cietsirdīgu un nežēlīgu apiešanās ar dzīvniekiem kā tad, kad nodaḷa vēl nebija nodibināta. Par katru obligatorisku pārkāpuma gadījumu tiek sastādīts protokols un vainīgais tiek saukts pie atbildības." 34

Savukārt salīdzinoši bieži cietsirdības gadījumi pret dzīvniekiem tika konstatēti Latvijas apriņ,̧os, kuros biedrības nodaḷas nebija dibinātas. Tātad dzīvnieku tirgoṇiem nebija jāuztraucas par to īpašumā esošo dzīvnieku konfiskāciju vai soda uzlikšanu. Tā 1937. gada 10. decembrī Valmieras nodalı ziņoja LDAB valdei:

"No vairākiem pilson,iem ienāk mums zin,ojumi, ka Limbažos un Smiltenē gada tirgos tiekot uzvesti pārdošanai ḷoti daudz kroplu, darbam nederīgu 
zirgu, kā arī pilsētā zirgi tiekot mocīti. Tas iespējams tādēl, ka Limbažos un Smiltenē nav nodibinātas nodaḷas, kas redzams no Jūsu pēdējā darbības pārskata. Tāpēc arī visi tie, kas tirgojas ar šādiem zirgiem, ierodas no pārējām pilsētām Limbažos un Smiltenē." ${ }^{35}$

Visbeidzot, biedrība deva samērā lielu ieguldījumu Latvijas sabiedrības humānā audzināšanā. Par to liecina ne tikai biedrības biedru pieaugošais skaits, bet arī cietsirdīgu apiešanās gadījumu pret dzīvniekiem pakāpenisks sarukums un sabiedrības reakcija uz šādiem gadījumiem.

\section{SAĪSINĀJUMI}

LDAB - Latvijas dzīvnieku aizsardzības biedrība

LNA LVVA - Latvijas Nacionālā arhīva Latvijas Valsts vēstures arhīvs

LPSR - Latvijas Padomju Sociālistiskā Republika

\section{IZMANTOTIE AVOTI}

Biedrības budžeti. LNA LVVA, 2327-1-20.

Biedrības dienas grāmata. 1935. g. - 1938. g. LNA LVVA, 2327-1-44.

Biedrības pilnsapulču un valdes sēžu protokoli, protokolu noraksti. Biedrības apkārtraksti un sarakste ar iestādēm un organizācijām dzīvnieku aizsardzības jautājumos. Ieñēmumu un izdevumu pārskati. LNA LVVA, 2327-1-2.

Biedrības raksti Rīgas pilsētas pagaidu izpildu komitejai, Finanšu tautas komisariātam u. c. iestādēm un biedriem par biedrības darbības organizācijas jautājumiem. Darbinieku darba apliecības u. c. LNA LVVA, 2327-1-92.

Dāmu komitejas un līdzekḷu vākšanas komitejas darbības instrukcijas. Dzīvnieku patversmes iekšējās kārtības noteikumi. Sarakste ar ārzemju dzīvnieku aizsardzības biedrībām par dzīvnieku aizsardzības jautājumiem, par dzīvnieku aizsardzības noteikumu pārkāpējiem u. c. LNA LVVA, 2327-1-10.

Latvijas dzīvnieku aizsardzības biedrība (Rīga). LNA LVVA, 2327-1

Nodaḷu delegātu ziņojumi par nodaḷu darbību. LNA LVVA, 2327-1-23.

Rīgas pilsētas valdei, Rīgas prefektūrai, Iekšlietu ministrijas Preses un biedrību nodalai u. c. par izrīkojumu un priekšlasījumu sarīkošanu, dzīvnieku aizsardzības noteikumu nepildījumu gadījumiem, labāko darbinieku godalgošanu, biedrības darbības paplašināšanu u. c. gadījumiem. LNA LVVA, 2327-1-49.

Sarakste ar ārzemju dzīvnieku aizsardzības biedrībām par dzīvnieku aizsardzības jautājumiem. Biedru pilnsapulces protokols 1938. g. 30. jūnijā. Ziņojums ministru prezidentam par biedrības darbību, sākot ar tās dibināšanu 1861. g. u. c. LNA LVVA, 2327-1-46.

Sarakste ar biedrības centrālo valdi par priekšlasījumu sarīkošanu, delegātu sapulču sasaukšanu, dzīvnieku patversmes ierīkošanu u. c. Ziņojumi policijas kārtībniekiem par dzîvnieku aizsardzības noteikumu pārkāpumu gadījumiem. Nodaḷas darbības pārskati. LNA LVVA, 2327-1-230.

1938. g. budžets un 1939. g. darbības plāns. LNA LVVA, 2327-1-21. 


\section{ATSAUCES UN PIEZİMES}

${ }^{1}$ Rīgas biedrība pret dzīvnieku mocīšanu (no vācu valodas: Rigaschen Vereins gegen das Quälen der Thiere).

${ }^{2}$ Latvijas Nacionālais arhīvs, Latvijas Valsts vēstures arhīvs, 2327-1-46, 128. lp.

${ }^{3}$ Rīgas dzīvnieku patversmes dāmu komiteja (No vācu valodas: Damenkomitee des Rigaer Tierasyls).

${ }^{4}$ LNA LVVA, 2327-1-23, 16. lp.

${ }^{5}$ LNA LVVA, 2327-1-49, 67. 1p.

${ }^{6}$ LNA LVVA, 2327-1-20, 2. 1p.

${ }^{7}$ LNA LVVA, 2327-1-23, 8. lp.

${ }^{8}$ Turpat, 1. 1p.

${ }^{9}$ LNA LVVA, 2327-1-46, 17. 1p.

${ }^{10}$ Biedrības rindas laika gaitā bija papildinājušas tādas sabiedrībā zināmas personas kā Rīgas pilsētas prefekts Pēteris Valdemārs Pommers, Rīgas prefektūras apsardzības rotas priekšnieks Paulis Jākobsons, Lauksaimniecības kameras vicedirektors un LU Lauksaimniecības fakultātes dekāns profesors Paulis Lejiņš, Latvijas armijas ǵenerālis Mārtiņš Harmanis, "Jaunāko Ziṇu” īpašnieki un redaktori Emīlija un Antons Benjaminni, resorāna "Otto Scwarz" īpašniece Dora Jirgensone, saldumu fabrikas "A/S K,uze" īpašnieks Vilhelms Kuze, Aspazija, mikrobiologs Augusts Kirhenšteins un daudzi citi.

${ }^{11}$ LNA LVVA, 2327-1-23, 6-7. 1p.

${ }^{12}$ LNA LVVA, 2327-1-21, 6. lp.

${ }^{13}$ Šìs LDAB nodaḷas atradās Istrā, Annas Kalncempjos, Aucē, Cēsīs, Daugavpilī, Jēkabpilī, Jelgavā, Kandavā, Kārsavā, Krāslavā, Liepājā, Ludzā, Madonā, Pasienē, Rūjienā, Rēzeknē, Tukumā, Valmierā un Ventspilī.

${ }^{14}$ Apstākḷus, kuri tika uzskatīti par cietsirdīgiem, Obligatoriskie noteikumi dzīvnieku aizsardzībai aprakstīja kā "katra darbība, kas dzīvniekiem rada ciešanas un bojā vinu veselību”. LNA LVVA, 2327-1-44, 110. lp.

${ }^{15}$ Dzīvnieku aizsardzības procesā plaši iesaistījās arī iedzīvotāji. Tā no 1935. līdz 1936. gada 31. jūlijam biedrība no iedzīvotājiem saṇēma vairāk nekā 3000 ziņojumu par iespējamiem cietsirdības gadījumiem pret dzīvniekiem, neieskaitot pašu biedru veiktos novērojumus. LNA LVVA, 2327-1-49, 136. lp.

${ }^{16}$ LNA LVVA, 2327-1-49, 219. 1p.

${ }^{17}$ Turpat, 217. lp.

${ }^{18}$ Pirmo reizi Vispasaules dzīvnieku aizsardzības diena tika atzīmēta 1931. gadā. Datums šai dienai ir izvēelēts par godu Svētā Asīzes Franciska nāves dienai. Svētais Asīzes Francisks tiek uzskatīts par dzīvnieku un vides aizbildni.

${ }^{19}$ LNA LVVA, 2327-1-49, 136. lp.

${ }^{20}$ Turpat, 46. lp.

${ }^{21}$ Turpat, 70. 1p.

${ }^{22}$ LNA LVVA, 2327-1-2, 426. 1p.

${ }^{23}$ LNA LVVA, 2327-1-49, 136. 1p.

${ }^{24}$ Turpat, 156. $1 \mathrm{p}$.

${ }^{25}$ LNA LVVA, 2327-1-23, 9. lp.

${ }^{26}$ Organizatorisku iemeslu dēl pirmo reizi Vispasaules dzīvnieku aizsardzības dienu Latvijā atzìmēja 6. oktobrī, nevis 4. oktobrī, kā tas bija ierasts citur pasaulē.

${ }^{27}$ LNA LVVA, 2327-1-49, 137. lp. 
${ }^{28}$ LNA LVVA, 2327-1-23, 9. 1p.

${ }^{29}$ Tā, piemēram 1935. gada 7. decembrī profesoram J. Žuromskim LDAB izteica rakstisku pateicību par apcerējuma "Zirga Lūgšana" ievietošanu viņa sastādītajā Katoḷu kalendārā, kam bija jāpalīdz dzīvnieku aizsardzības jautājumu aktualizēt arī Latgales iedzīvotāju vidū. LNA LVVA, 2327-1-49, 29. 1p.

${ }^{30}$ LNA LVVA, 2327-1-23, 11. lp.

${ }^{31}$ LNA LVVA, 2327-1-2, 30. 1p.

${ }^{32}$ LNA LVVA, 2327-1-92, 6. 1p.

${ }^{33}$ LNA LVVA, 2327-1-230, 2. lp.

${ }^{34}$ LNA LVVA, 2327-1-23, 3. 1p.

${ }^{35}$ LNA LVVA, 2327-1-10, 122. lp. 


\title{
THE ACTIVITIES OF THE LATVIAN SOCIETY FOR THE PROTECTION OF ANIMALS (1935-1940)
}

\author{
MĀRTIN̦Š DĀTAVS \\ MA in History \\ Email:martins.dataus@gmail.com
}

\begin{abstract}
The paper describes and analyses the main activities and the development of the Latvian Society for the Protection of Animals in the period between the Society's reorganisation in 1935 and its liquidation in 1940. In this period the main goals of the organisation were to prevent cruelty against animals in society and to help the animals that had fallen in misfortune. To reach these goals, the members of the Latvian Society for the Protection of Animals achieved the adoption of various animal protection laws as part of the Latvian legislation, organised the work of a veterinary ambulance and the first and then only animal shelter in Riga. The Society also popularized its animal protection ideas by organising various public events and distributing literature.
\end{abstract}

Keywords: animal protection, non-governmental organisations.

\section{SUMMARY}

The paper examines the activities of the Latvian Society for the Protection of Animals between 1935 and 1940. Although the roots of the Society date back as far as 1861, the consequences of World War I and the unsuccessful Society's administrative management served as a reason for the Society to reorganise itself and begin work almost from a scratch, without any experience and financial resources. However, the Society's new leadership successfully managed to increase the budget and membership, which allowed it to regain its previous work capacity and establish 19 regional branches by 1940 .

One of the greatest achievements of the Latvian Society for the Protection of Animals was the adoption of new animal protection laws as part of the Latvian legislation, which significantly increased animal welfare requirements. The Society also actively controlled the observance of these laws and tried to bring to justice every person, who purposely broke them. 
As a result of these activities, the number of reported cases of cruelty towards animals decreased.

Another significant achievement of the Society was the establishment of an animal shelter in Riga, whose main functions were the medical treatment of sick animals and the provision of a shelter to them, as well as humane killing of stray or incurable animals. In order to attract new members and spread the ideas of animal protection, the Society organised various events and distributed literature.

Shortly after the Soviet occupation of Latvia in 1940, the Latvian Society for the Protection of Animals was liquidated. However, the activities of the Society during the five years of its existence can be considered as successful. 


\title{
AIZMIRSTIE: GIDEONS ERNESTS FON LAUDONS UN TOCES PUSMUIŽA. CILVËKA UN VIETAS ATGRIEŠANĀS STĀSTS
}

\section{LITGA IRBE}

Mg. hist.

E-pasts: irbe.liga@gmail.com

\begin{abstract}
ANOTĀCIJA
Publikācija ir plašāka pētījuma par Toces pusmuižas un ar to saistīto personu likteṇiem pirmais posms. Šĩs pusmuižas vēsture palīdz ilustrēt ne tikai personu un vietu aizmiršanas procesu un atmiṇu pārklāšanos un atgriešanu kolektīvajā atmiṇā, bet arī valstiskas nozīmes procesu, piemēram, 20. gs. 20. gadu agrāro reformu un ar to saistītās problēmas, kā arī muižu likteṇus pēc Latvijas okupācijas.
\end{abstract}

Atslēgas vārdi: Toce, L̦audona, Gideons Ernests fon Laudons (Loudons), Reinholds Lamsters, Indriḳis Rušmanis, pusmuiža, Vidzemes muižu vēsture, pusmuižu vēsture, lokālā vēsture, dzimtu vēsture, agrārā reforma, atmiṇa.

\section{IEVADS}

Mūsdienās arī Latvijā arvien vairāk par atmiṇu runā ne tikai kā par psihisku izziņas procesu, kura laikā cilvēks saglabā un atjauno apziṇā noteiktu informāciju. Tās galvenos procesus - iegaumēšanu, atcerēšanos un aizmiršanu (Firsts et al. 2015) - izmanto arī, lai pētītu un reprezentētu pagātnes notikumus, analizējot tos caur atmiņu dažādu veidu prizmu. "Atmiņas veido identitāti, un atmiņas arī saglabā identitāti” (Orehovs 2015, 5), tātad tām ir būtiska loma vietas, laika un telpas apzināšanā un piederības sajūtas radīšanā un uzturēšanā nākamajām paaudzēm. Atmiṇas tiek iekḷautas arī kultūras definīcijas pamatelementu klāstā (Hanovs 2016, 19).

2017. gadā apritēja 300 gadi kopš izcilā 18. gs. karavadoṇa Gideona Ernesta fon Laudona (Gideon Ernst, Freiherr von Laudon, 1717-1790, 
von Laudon, Loudohn, фон Лаудон) dzimšanas Toces (Totze, Tautzen, Tootzen, Totzen) pusmuižā, tomēr, neskatoties uz ievērojamo jubileju, viņa militārajiem sasniegumiem, plašo atpazīstamību Eiropā, īpaši Čehijā un Austrijā, savā dzimtajā novadā gan viņš pats, gan viņa dzimtā vieta ir maz zināma.

Toces pusmuiža atrodas Madonas novada L̦audonas pagastā, apdzīvotā vietā Toce blakus Tocìtei (arī Tocei), kas netālu ietek Aiviekstē. Vēsturiski tā apzīmēta kā vieta pie Toces līča vai grīvas, taču nav skaidrs, vai tas attiecināts uz Aivieksti (līcis) vai Tocīti (grīva). Vietas nosaukums devis vārdu pie L̦audonas muižas piederošajai pusmuižai (Das Inland 1846, Nr. 12), kuras pirmsākumi precīzi nav zināmi. 14. gs. ir senākais laiks, kas minēts fon Laudonu dzimtas saistïbai ar Toces pusmuižas vietu (LKV 1935, 22539; von Krsowitz 1789, 2). Kā pirmais dzimtas pārstāvis, kas ieradies no Anglijas Livonijā, tiek minēts kāds Matiass fon Laudons (Mathias von Laudon), kurš, pateicoties veiksmīgam dienestam, ieguvis divas bruṇniecības muižas L̦audonu un Toci (von Krsowitz 1789, 2). Toce bruṇniecỉbas muižas statusu saglabāja līdz pat agrārajai reformai 20. gs. 20. gados. Citi autori fon Laudonu saistību ar pusmuižas vietu min, sākot ar 15. gs., atsaucoties uz Rīgas arhibīskapa Henninga Šarpenberga (Henning Scharpenberg) 1432. gada Simeona Jūdas dienā (28. oktobrī) veikto četru arklu zemes gabala izlēṇošanu kādam Otto Laudonam (Das Inland 1846, Nr. 12; Falck 1905, Nr. 15; von Transehe- [Roseneck] 1904, 106). Zìmīga ir piezìme, ka zemes gabals jau iepriekš bijis nodots O. Laudona tēvam, tātad dzimta ar šo vietu saistìta jau pirms 1432. gada (Das Inland 1846, Nr. 12). Tātad no iepriekš minētā var secināt, ka Toces pusmuiža vēsturiski kopš pirmsākumiem saistìta ar Ḷaudonas muižu, taču tās izveides brīdis precīzi šobrīd nav zināms.

\section{AVOTI UN HISTORIOGRĀFIJA PAR TOCES MUIŽU}

Būtisks faktors atmiņu veidošanā un uzturēšanā ir pieejamajiem un izmantotajiem avotiem. Latvijas Nacionālā arhīva Latvijas Valsts vēstures arhīvs ir nozīmīgākais avotu glabātājs par Toces pusmuižu un ar to saistītajām personām. No šobrīd apzinātajiem materiāliem kā vērtīgākie jānorāda 1679. fondā esošie materiāli par Toces pusmuižas sadalī̌anu un ar to saistītajām problēmām 20. gs. 20.-30. gados (LNA LVVA, 1769-172-1284), 2574. fondā esošã lieta par palīdzības lūgumu Latvijas valstij saistībā ar Toces pusmuižas mantojuma sadali un zaudējumiem (LNA LVVA, 25744-1294). Par senāku pusmuižas vēsturi vērts izcelt 77. fondā esošos materiālus par 19. gs. dvēseḷu revīzijām (LNA LVVA, 77-14-303), 7404. fondā esošos pusmuižas apkārtnes plānus, kas l̦auj gūt priekšstatu par vietas apdzīvotības blīvumu, upju gultnēm, celiem 17. gs. (LNA LVVA, 7404-3-44), 
kā arī 6999. fondā esošos materiālus par pusmuižu, sākot jau no 17. gs. (LNA LVVA, 6999-12-83).

Madonas novadpētniecības un mākslas muzejā krājumā esošo materiālu klāsts par Toci un ar to saistītajām personām raksturojams kā nabadzīgs un sekundārs. 1997. gadā veiktajā materiālu vākšanas ekspedīcijā L,audonas pagastā maršruta, kas veda gar Toces pusmuižu, atskaitē nav nekādu atzīmju par tās apmeklēšanu, un līdz ar to tai, atškirīībā no citām ēkām, izpētes maršrutā nav uzzīmēts ēkas un tās apkārtnes plāns, iztaujāti tobrīd vēl dzīvie iedzīvotāji. 1997. gada ekspedīcijas laikā, iztaujājot L̦audonas pagasta iedzīvotājus, fiksētas dažu iedzīvotāju fragmentāras atmiņas par Toces pusmuižas Latvijas Republikas laika īpašnieku, zvērinātu advokātu Reinholdu Lamsteru (13.02.1883., Barkava - ?), darbu pie vin, vai Toces zirgaudzētavā, vai sovhozāi ${ }^{1}$ Muzejā pieejami arī 20. gs. 90. gados Ḷaudonas skolēnu apkopotie materiāli par bijušo Toces pusmuižas ìpašnieku Rušmaņu dzimtu (MNM Plg 6943:5, 1.-31. lp.), atseviškas ar Toci vai ar to saistīto dzimtu pārstāvju fotogrāfijas (MNM 20898; MNM 4232; MNM 34997).

Vērtīgs avots pusmuižas izpētei ir publicētie avoti par to un publikācijas par G. E. fon Laudonu un viņa dzimtu. Piemēram, 1926. gada 1. novembrī “Tieslietu Ministrijas Vēstnesī” (Nr. 11-12) publicēts Senāta spriedums par aț̣aujas izdošanu R. Lamsteram atsavināt trīs zemes gabalus no Toces muižas (TMV 1926, Nr. 11-12). Sprieduma materiāli l̦auj iegūt informāciju par agrārreformas norisi, veidu, kā tika organizēta muižas zemes saglabāšana viena īpašnieka rokās, un iesaistītajām personām. Vērtīga faktolog̣iska informācija par Toces pusmuižas īpašniekiem atrodama divos pētījumos par muižām Vidzemē (Hagemeister 1836; Stryk 1885). Savukārt par G. E. fon Laudonu un viṇa dzimtu vairākas noderīgas publikācijas atrodamas 19. gs. / 20. gs. sākuma vācu valodā iznākošajā presē un rakstu krājumos (Das Inland 1846, Nr. 12; von Eckardt 1869, 183-272; von Löwis of Menar 1902, 163-166; von Transehe- [Roseneck] 1904, 106-109).

Kopējā iezīme šajās publikācijās ir koncentrācija uz fon Laudonu dzimtas ǵenealoǵiju, dzimtas uzvārda izcelsmi, nevis viņa dzimtās vietas vēsturi. Jāuzsver, ka pirmie darbi par G. E. fon Laudonu tika izdoti jau viṇa dzīves laikā (piemēram, von Krsowitz 1789). Neatkarīgi no izdošanas laika kopīgā iezīme ir koncentrēšanās uz G. E. fon Laudona militāro karjeru, un Toces pusmuiža tiek pieminēta tikai kā viṇa dzimtā vieta Vidzemē (Janko 1869; Malleson 1884; Pesendorfer 1989; Bélina et al. 2017).

Pieejamo avotu un historiogrāfijas klāstu par Toces pusmuižu un ar to saistītajām dzimtām un personām nevar apzīmēt kā plašu, ${ }^{2}$ un tās izpētē joprojām paliek būtiski problēmjautājumi, piemēram, kad īsti tika izveidota Toces pusmuiža un kad tā nonāca fon Laudonu dzimtas īpašumā, nav zināmi visi muižas īpašnieki, ir l,oti maz informācijas par E. G. fon Laudona bērnību un jaunību un viesošanos Tocē. Tāpat šobrīd nav iegūti materiāli 
par pusmuižas izskatu, nav zināms tās interjera priekšmetu liktenis pēc padomju varas okupācijas, nav skaidrības arī par tās pēdējā īpašnieka R. Lamstera un viņa kustamo mantu likteni utt.

\section{TOCE UN AR TO SAISTĪTĀS DZIMTAS KOLEKTĪVAJĀ ATMIṆĀ}

Toces pusmuiža bijusi saistīta ar vismaz četrām dzimtām: fon Laudonu dzimtu (15. gs. - 19. gs. 40. gadi); fon Mainersu dzimtu (von Meiners, 19. gs. 40.-80. gadi); Pētersonu-Rušmaņu dzimtu (19. gs. 80. gadi 1920. gads) un Lamsteru dzimtu (1920-?).

\section{Fon Laudonu dzimta}

Pirmais periods ir nosacīts, jo tajā var iekḷaut laiku no 18. gs. beigām līdz pat 20. gs. 20. gadiem. Laiks, kad pusmuiža pati par sevi pastiprinātu interesi pētniekos un sabiedrībā neizraisa, bet tā tiek pieminēta kā zināmākā fon Laudonu dzimtas pārstāvja G. E. fon Laudona dzimtā vieta un tiek mēǵināts atbildēt uz jautājumu par fon Laudona dzimtas uzvārda saistību ar apdzīvotas vietas "Ḷaudona” nosaukumu. Galvenā uzmanība šajā posmā ir vērsta nevis uz G. E. fon Laudona personību, dzimto vietu vai fon Laudona dzimtu kopumā, bet gan uz vin,a izcelsmi (Falck 1905, Nr. 15; von Löwis of Menar 1902, 163-166; von Transehe- [Roseneck] 1904, 106-109). Divi nopietnākie pētījumi par fon Laudonu ǵenealog̣iju pieder baltvāciešiem Aleksandram Georgam Astafam fon Tranzē-Rozenekam (Alexander Georg Astaf von Transehe-Roseneck) (von Transehe- [Roseneck] 1904, 106-109) un Kārlim fon Lēvisam of Menāram (Karl von Löwis of Menar) (von Löwis of Menar 1902, 163-166).

Fon Laudonu dzimtas saistība ar Toci šajā periodā tiek skatīta plašākā kontekstā, cenšoties rast atbildi uz jautājumu par fon Laudonu un vietas, pie kuras pieder arī Toces pusmuiža, proti, Ḷaudonas, saistību. Historiogrāfijā pastāv vismaz trīs versijas:

\section{Dzimta pārṇēmusi vietvārdu kā savas dzimtas uzvārdu.}

Versija nav guvusi plašu atbalstu pētnieku vidū, taču atsevišķās publikācijās (LKV 1935, 22539; Falck 1905, Nr. 15) tā tiek pieminēta.

\section{Dzimta devusi nosaukumu vietai.}

Fon Laudonu dzimta devusi nosaukumu vietai (Falck 1905, Nr. 15; Malleson 1884, 11). Tā atrodama, piemēram, teicēja Pētera Maskata (tobrīd 82 g. v.) nostāstā par to, kā cēlies Ḷaudonas vārds³ (LFK 1980). Nostāsts nesniedz nekādas, pat aptuvenas ziṇas par tā izcelsmes laiku. 
Savukārt kāds Jānis Kḷavinšs 20. gs. 90. gadu vidū pierakstījis Ḷaudonas vidusskolas skolēnu stāstījumu, ka pēc nostāstiem "ap 1812. gadu tagadējo L,audonu nopircis kāds augstāks virsnieks, Laudāns, un to nosaucis savā vārdā: par Ḷaudonu vai Laudonu" (MNM Plg6934:5, 27). Ir redzams, ka cilvēka/cilvēku atmiņās ir notikusi ievērojama faktu un laika notikumu pārbīde, jo Ļaudona jau pirms 19. gs. sākuma vēstures avotos minēta ar nosaukumu "Laudohn" un Laudonas muiža ar Toces pusmuižu fon Laudonu dzimtai pieder vismaz no 15. gs. Iespējams, apzīmējums "augstāks virsnieks" attiecināms uz G. E. fon Laudonu kā zināmāko ar L̦audonu saistīto militārpersonu, latviskojot viṇa uzvārdu. Tomēr šobrīd tie ir tikai minējumi.

3. Dzimtas uzvārda un vietas nosaukumu vienādība ir sakritība.

Divos jau G. E. fon Laudona dzīves laikā publicētos darbos fon Laudonu dzimtas un tās uzvārda izcelsme tiek saistīta ar Angliju un Skotiju. Piemēram, mācītājs Augusts Vilhelms Hupels (August Wilhelm Hupel) 18. gs. beigās norāda, ka Rīgas arhibīskapam piederošā L,audonas pils devusi vārdu ne tikai apdzīvotajai vietai, bet arī visam L,audonas baznīcas apgabalam (Hupel 1788, 295), tādējādi norādīdams, ka fon Laudonu dzimta, par kuras izcelsmes vietu viņš min Angliju, nav saistāma ar vietvārda izcelsmi. Gadu vēlāk publicētajā Ferdinanda Taubmana fon Krsovitca darbā "Laudons Leben und Heldenthaten" teikts, ka pirms iecel̦ošanas Skotijā fon Laudonu dzimta dzīvojusi Normandijā, taču tieši Skotijā no pilsētas, vārdā "Loudun" dzimta ieguvusi savu uzvārdu (von Krsowitz 1789, 2). Uz fon Laudonu dzimtas saistību ar Skotijas dižciltīgo Laudonu dzimtu (vieta Ayrshire) vai vienkārši Skotiju norāda arī citi autori (Malleson 1884, 11; Rodatz 1941 Nr. 229).

Visi varianti par fon Laudonu dzimtu, tās izcelsmi un ierašanās laiku Livonijā līdz 15. gs. ir tikai vēsturiskas leǵendas bez ǵenealoǵiska vai heraldiska pamatojuma (Falck 1905, Nr. 15). Līdz ar to var secināt, ka pētnieku vidū nav strīdu par to, ka L,audona kā vieta bija apdzīvota jau pirms fon Laudonu dzimtas ierašanās, taču viņiem nav vienprātības ne par L,audonas nosaukuma izcelsmi, tā saistību ar fon Laudonu dzimtu, ne arī par fon Laudonu dzimtas izcelsmi un precīzu ierašanās laiku Livonijā. Cilvēku atmin̄ās L,audonas vietvārda nosaukuma izcelsmei nav vienota skaidrojuma, tāpat to atmiṇās nav saglabājušies fakti par fon Laudona dzimtas piederīgajiem kā Toces pusmuižas īpašniekiem, to izskatu vai personīgajām īpašìām.

Tātad faktiski dzīvās atmiṇas pastāvēšanas laikā faktu uzkrājēji un tālāki nesēji par fon Laudonu dzimtu bija nevis Ḷaudonas/Toces iedzivotāji, bet pētnieki, kuri pastarpināti apkopoja rakstiski pieejamo informāciju (arī nostāstus) par fon Laudonu dzimtu un tās piederīgajiem. 


\section{Fon Mainersu dzimta (uon Meiners, 19. gs. 40.-70. gadi) un \\ Pētersonu-Rušmaṇu dzimta (19. gs. 80. gadi - 1920. gads)}

Diemžēl par divām nākamajām dzimtām, kuru īpašumā nonāca Toces pusmuiža, iegūts ḷoti niecīgs informācijas daudzums. Pieejamā informācija par Pētersonu-Rušmaņu dzimtu šobrīd ir tikai viens neprofesionāls pētījums par konkrētas dzimtas vēsturi, tādēḷ vēl nav iespējams sniegt atbildi uz jautājumu, kā mainījās Toces pusmuiža šo dzimtu pārstāvju saimniekošanas laikā.

Zināms, ka 1838. gada 23. aprīlī Toce pēc vairāku gadsimtu būšanas fon Laudonu dzimtas īpašumā pirkuma ceḷā nonāca Bruǵa tiesas adjunkta Fridriha fon Meinersa (Friedriech von Meiners) īpašumā (Stryk 1885, 281), kurš to 1868. gadā cedēja meitai Mariannai fon Meinersei. 1870. gadā M. fon Meinerss iek̦īāja Toci un Ļaudonas īpašumu Indriķim Rušmanim (Indrick Russman, arī Heinrichs Pētersons-Rušmanis), kurš 1879. gadā izsoles ceḷā kḷuva par Toces pusmuižas īpašnieku (BZIP Nr. 3, 21.03.1932.; Stryk 1885, 278). Pēc I. Rušmaṇa nāves 1908. gadā Toces pusmuižu manto viņa dēls Aleksandrs Pētersons-Rušmanis (MNM Plg. 6943, 12), kurš īpašumu 1920. gadā pārdeva zvērinātam advokātam Reinholdam Lamsteram.

No abām dzimtām kā zināmākais pārstāvis jāmin Indriḳis Rušmanis.

\section{Lamsteru dzimta}

Pēdējais Toces pusmuižas īpašnieks līdz Latvijas okupācijai bija jau pieminētais R. Lamsters. 1920. gada 16. septembrī Latvijas Satversmes sapulce pieņēma Agrārreformas likuma 1. daļu "Par Valsts zemes fonda nodibināšanu”, kas paredzēja arī vairāk nekā 200 pusmuižu, t. sk. Toces pusmuižas, sadalīšanu, jo tās platība bija 709,63 desetīnas (1 desetīna - 1,0925 ha) jeb 775,270 ha. Lai R. Lamsteram piederošais īpašums paliktu neatsavināts, viņš îstenoja šādu shēmu, proti, sadalīja īpašumu starp saviem radiniekiem, apgalvodams, ka īpašums iegādāts jau 1917. gadā un tā iegādei no saviem tuviniekiem aizṇēmies lielas naudas summas, apsolot pēc tā iegūšanas izdalīt katram proporcionālu zemes gabalu. Tikai divas dienas pēc likuma pieņemšanas, t. i., 18. septembrī, iepriekš minētie R. Lamstera tuvinieki vērsās Tieslietu ministrijā ar paskaidrojumu par it kā R. Lamsteram aizdotajām summām un viņiem izdalītajiem zemes gabaliem, proti, brālim Kārlim Lamsteram 9145,11 desetīnas (Jauntoces mājas); māsai Bertai Saliņai 99,71 desetīnas (Salinu mājas) un brāla sievas tēvam Reinholdam Budevicam - 49,71 desetīnas (Jānišu mājas). Lai gan nebija tiešu pierādījumu, neoficiāli tika minēts, ka R. Lamsteram palīdzēja kolēǵis - advokāts, tobrīd tieslietu ministra postenī esošais Rūdolfs Bēnuss, kurš 20. gs. 30. gados tika notiesāts par naudas piesavināšanos un ar kura atbalstu visi iepriekš minētie zemes gabali tika koroborēti (ierakstīti īpašumu zemesgrāmatā) uz 
jauno īpašnieku vārdiem. Kā vēlāk tiks uzsvērts Senāta lēmumā, tad Tieslietu ministrijā netika iesniegts nekāds apstiprinājums faktam, ka patiešām ir ticis noslēgts līgums starp R. Lamsteru un viņa tuviniekiem, un arī pats R. Lamsters neapgalvoja, ka tāds līgums līdz 1920. gada 16. septembrim būtu noslēgts, turklāt zemes nedrīkstēja atdalīt, jo tādējādi Toces pusmuižai kā bruņniecības muižai klāt palika mazāk zemes, nekā bija noteikts likumā (TMV 1926, Nr. 11-12; Latvis 1925, Nr. 1084).

Pēc vietējo atvalināto karavīru sūdzībām (LNA LVVA, 1679-1721284, 9), 1923. gada 5. novembrī L,audonas pagasta Zemes ierīcības komiteja ierosināja Centrālajā zemes ierīcības komitejai šo zemju sadalīšanas lietu pārsūtīt izskatīšanai Senātā, kas tika arī izdarīts, un 1925. gada 22. martā Senāts nolēma, ka Toces muižas zemes sadalīšana bijusi nelikumīga un tā ieskaitāma valsts zemes fondā. 1926. gada 10. martā zemei bija jānonāk valsts zemju fondā, taču tā paša gada maijā publikācijā izdevumā "Laukstrādnieks" tika norādīts, ka L,audonas pagasta valde san,ēmusi rīkojumu muižas zemi atstāt to pašreizējiem īpašniekiem, proti, R. Lamsteram un viņa radiniekiem (LS 1926, Nr. 19).

Gan Toces pusmuižas dalǐšana, tiesas process un tā atspoguḷošana presē, gan R. Lamstera izlolotā zirgaudzētava l̦āva Tocei iegūt atpazīstamību Latvijas brīvvalsts laikā kā R. Lamstera īpašumam. Pēdējā norāde par to, kāda varēja būt Toces pusmuiža līdz padomju okupācijai, atrodama rakstā "Agrāk un tagad" (Cīn,a 1941, Nr. 123), kurā starp propagandas rindām divus mēnešus pēc muižas pārņemšanas no R. Lamstera par to atrodama interesanta piebilde: “Tiešām, Lamstera dzīvoklis saglabāts kā īsts mūzejs. Te ir zelts, sudrabs, dārglietas, mākslas darbi, dārgas mēbeles. Viss te savākts un samests, bez gaumes un kārtības. Viss te bijis svērts un vērtēts naudā [..]. Atnāciet pēc gada, pēc diviem, - saka atvadoties sovchoza vadītāji, - tad redzēsiet, kā pārmainījusies dzīve bij. Toces muižā." (Cīn,a 1941, Nr. 123) Šobrīd nav zināms, vai tās bija vecās Toces pusmuižas mēbeles vai Lamsters tās atveda un kas notika ar publikācijā minētajām lietām. Toce padomju okupācijas gados kḷuva par dzivesvietu iebraucējiem, vietējo valodā kḷūdama par "pufaikciemu". Pusmuiža un tās apkārtne netika pienācīgi kopta, tādēḷ pakāpeniski kḷuva par arvien nepievilcīgāku vietu.

\section{TOCE UN AR TO SAISTITTĀS PERSONĪBAS INVIDUĀLAJĀ UN KOLEKTĨVAJĀ ATMIṆĀ}

Toces pusmuižas 500 gadu vēsturē ir vismaz trīs personas, kuru dēḷ Toces pusmuiža iegūst zināmu atpazīstamību noteiktā laika posmā savu laikabiedru vidū, bet pašas personības spēj palikt atmin̄ās ilgāku laiku. 


\section{Gideons Ernests fon Laudons}

Dzimis 1717. gada 2. (13.) $)^{4}$ februārī Lielā Ziemeḷu kara laikā Toces pusmuižā atvalinātas militārpersonas Otto Gerharda fon Laudona (Otto Gerhard fon Laudohn ${ }^{5}$ ) un vina sievas Sofijas Eleonoras fon Bornemanes (Sophie Eleonore von Bornemann, arī Bornemund) ğimenē (Falck 1905, Nr. 15). Kristīts kā Gideons Ernsts ${ }^{6}$ fon Laudons. Jau agrā bērnībā izrādījis pastiprinātu interesi par armiju, tādēl, nolemts viṇu gatavot militārpersonas karjerai (von Krsowitz 1789, 5). 1732. gadā (citviet 1731. gadā - Malleson 1884, 12) kā kadets pievienojās Pleskavas kājnieku pulkam (Falck 1905, Nr. 15). Sākot ar 1733. gadu, piedalījies aktīvajās karadarbībās Krievijas impērijas armijas sastāvā (1736.-1739. gadā piedalījās Krievu-turku karā u. c. militārās kampaṇās). 1738. gadā apmeklēja Toci (Malleson 1884, 13). 1740. gadā G. E. fon Laudons kā virsleitnants atvalinājās no dienesta un devās meklēt jaunu dienesta vietu. Pirms došanās tālāk uz Eiropu viņš viesojās Stokholmā pie onkuḷa, kur apsvēra iespēju uzsākt dienestu zviedru armijā, un arī Toces pusmuižā (Falck 1905, Nr. 15). Pēc neveiksmīga mēǵinājuma pievienoties Prūsijas armijai ar paziņu atbalstu un ieteikumu 1741. gadā tika pien,emts Austrijas armijā. Piedaloties Austrijas mantojuma karā (1740-1748), 1744. gadā smagi ievainots (Malleson 1884, 16, 19). No 1746. līdz 1756. gadam kā kapteinis dienēja robežapsardzībā Buničā. 1746. gadā (citviet - 1748, Falck 1905, Nr. 15) apprecējās ar 16 gadus veco Klāru fon Hāgenu (Clara von Haagen). Dažviet tiek norādīts, ka pārim bērnu nebija (Falck 1905, Nr. 15), bet citos pētījumos (Malleson 1884, 28) - ka ǵimenē

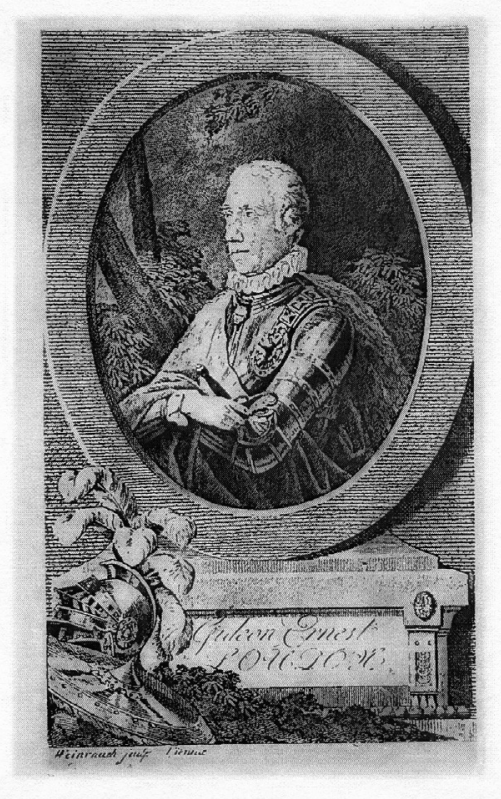

1. attēls. G. E. fon Laudons. Attēls no Malleson G. B. Loudon: A Sketch of The Military Life of Gideon Ernest, Freiherr von Loudon, Sometime Generalissimo of The Austrian Forces. London: Chapman and Hall, 1884, 9. 
piedzima divi dēli, kuri mira agrā bērnībā. 1749. gadā E. G. fon Laudons konvertējās katoḷticībā. 1750. gadā ieguva majora pakāpi.

Austrijas armijas sastāvā aktīvi iesaistījies Septingadu karā (1756-1763), gūdams uzvaras pār Prūsijas armiju svarīgās kaujās (Kunersdorfas (1759), Lanshūtes (1760)). 1757. gadā san̄ēma ǵenerālmajora pakāpi. 1773. gadā atvalinājās no aktīvā karadienesta, taču atgriezās un piedalījās Bavārijas mantojuma karā starp Austriju un Prūsiju (1778-1789). 1778. gadā G. E. fon Laudonam pieškirta feldmaršala pakāpe. 1789. gadā iecelts par Austrijas armijas virspavēlnieku karā pret Turciju (1787-1791). Pēc 1789. gada 8. oktobrī veiktās Belgradas iekarošanas triumfāli atgriezās Vīnē un saṇēma ǵenerālisimusa titulu. Miris 1790. gada 14. jūlijā Morāvijā (mūsdienās - Novi Jičīna (Nový Jičin) Čehijā).

No šobrīd rīcībā esošajiem materiāliem var secināt, ka Tocē dzimušais G. E. fon Laudons dzimtajā vietā dzīves laikā atgriezās tikai divas reizes, t. i., laikā pirms pievienošanās Austrijas armijai. Pusmuiža palika fon Laudonu dzimtas īpašums vēl gandrīz pusgadsimtu.

\section{Indriḳis (Heinrichs) Rušmanis}

Dzimis 1817. gada 8. novembrī. Kristīts Kalsnavas luterāṇu baznīcā. Vēlāk, iespējams, kad māte apprecējusies otro reizi, ieguvis otru uzvārdu Pētersons, kḷūdams par Indriḳi Pētersonu-Rušmani. Precējies ar Annu Getlingu (Anna Goettling), ǵimenē septiṇi bērni. Miris 1908. gada 24. aprīlī. Apglabāts L,audonas kapos.

Par I. Rušmani ir saglabājies nostāsts, ka viņš bijis parasts ganu puika, bet, pateicoties Krustpils muižkungam, ieguvis labu izglītību un vēlāk ar viltu un, iespējams, nelikumīgi iegūtu naudu ticis pie L,audonas un Toces īpašumiem (MNM Plg. 6943, 27-31). Mazāk zināms nekā G. E. fon Laudons un R. Lamsters.

\section{Reinholds Lamsters}

Dzimis 1883. gada 13. februāri Barkavas pagastā lauksaimnieka gimenē. Pabeidzis Maskavas Universitātes Tieslietu fakultāti un no 1915. gada strādājis par zvērinātu advokātu Rīgā. Bijis A. Niedras advokāts. R. Lamstera vājība bija zirgi, viņš bija Latvijas sugas zirgkopības veicināšanas biedrības priekšnieks. 1941. gadā tika apcietināts, taču tālākais liktenis nav skaidrs. Kā norādījis prof. Ēriks Jēkabsons savā darbā par Latvijas advokatūru, tad, pēc nepārbaudītām zin̄ām, R. Lamsters miris 1941. gadā (Jēkabsons et al. 2007, 314). 1942. gadā "Rīkojuma Vēstnesī” bija publicēts Rīgas apgabaltiesas 3. civilnodaḷas paziņojums, ka, pamatojoties uz CPL 1562. pantu, ar šīs pašas tiesas 1942. gada 24. februāra lēmumu nodibina aizgādību 


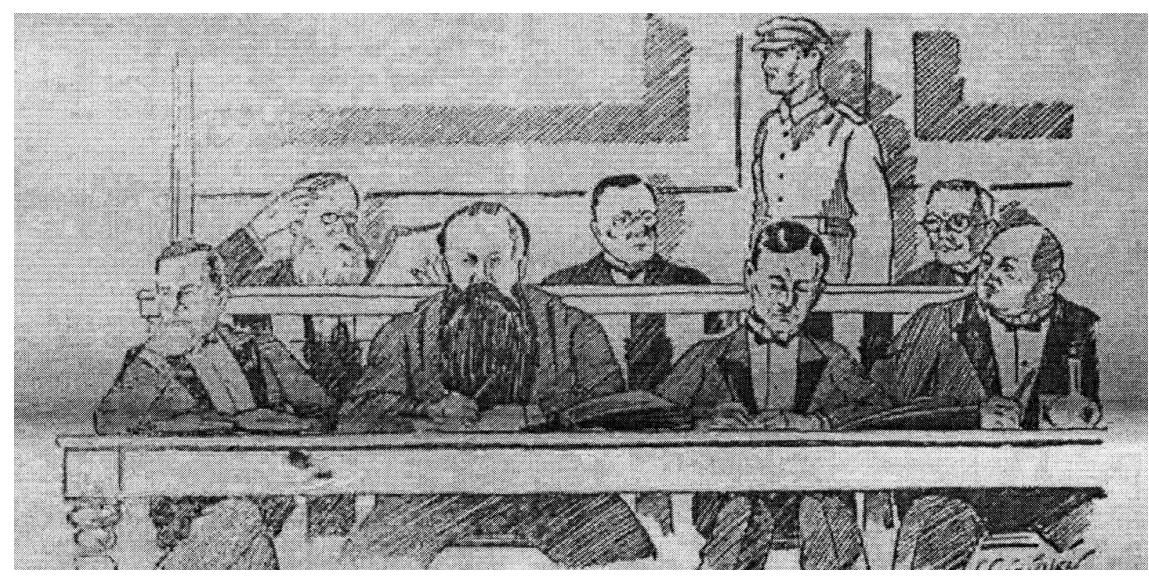

2. attēls. Advokāts Reinholds Lamsters (otrais no kreisās pirmajā rindā) A. Niedras tiesas prāvas laikā. 1924 (Andreewa Needra teesaschana. Talsu Vēstnesis, 28.08.1924., Nr. 35, 2).

promesošā Reinholda Lamstera, dzīv. Rīgā, Ādolfa Hitlera ielā (iepriekš Brīvības iela) 44/46-14, mantai (RV 1942, Nr. 29). 2017. gadā intervijas laikā 92 gadus vecais Madonas iedzīvotājs Jānis Šusters dalījās atmiņās par R. Lamstera mirstīgo atlieku atvešanu no Rīgas uz Madonu. R. Lamsters, vietējo iedzīvotāju vārdiem runājot, "bija resnākais cilvēks pasaulē", kura atvešana notika ar ippašu vagonu un kurš tika izcelts laukā no vagona tajā pašā vietā, kur pulkveža O. Kalpaka lị̄isis. Pēc J. Šustera teiktā, R. Lamsters aizvests un apglabāts Ḷaudonas kapos, taču viņš neatcerējās notikušā gadu (Šusters 2017). Kā redzams, tad J. Šustera atmin̄ās dominējošais fakts bija R. Lamstera izskats un mirstīgo atlieku pārvietošanas vieta, nevis laiks vai citi faktori.

Tātad G. E. fon Laudons ir tikai viena no personībām, kura saistīta ar Toces pusmuižu un kura savu sasniegumu vai darbības dēl varēja saglabāties individuālajā un kolektīvajā atmiņā. Cilvēku atmiṇās visspilgtāk palikuši nevis fon Laudonu vai Pētersonu-Rušmaņu dzimtai piederīgie, t. sk. G. E. fon Laudons un I. Rušmanis, bet tieši R. Lamsters.

Prof. Pìters Bērks kādā savā lekcijā uzdeva interesantu jautājumu: kāpēc par kādiem cilvēkiem veidojas mīti, bet par citiem ne? Viņš noliedza indivīda personības īpašǐbu dominanci, prioritāri akcentēdams indivīda īpašību sakritību ar "attiecīgā laika varoṇa vai l̦aundara stereotipu" (Bērks 1998, 36).

Respektīivi, fon Laudona nepalikšana vietējo iedzīvotāju atmiņās saistāma nevis ar faktu, ka viņš Tocē uzturējās īsu laiku, bet, ja pieņem šādu pamatojumu, ar viņa personības neinteresantumu. Gluži pretēji - R. Lamsters iemiesoja 20. gs. 20. gadu Latvijas veiksmes stāstu - dzimis laukos, kḷuvis bagāts un slavens advokāts, iesaistīts virknē skandālu un izcēlās ar savu 
izskatu. Patiešām, noliekot līdzās šos divus ar Toci saistītos cilvēkus, nav šaubu, kurš no tiem uzvarēs cīṇā par vietu cilvēku atmiṇās, jo ar fon Laudonu nesaistās nekādi spilgti notikumi, ja par tādu neuzskata viņa piedzimšanas Tocē faktu, un tieši tas un vienīgi tas arī ir saglabājies vietējo cilvēku atmin̄ās. Viṇa dzimtajā vietā nav saglabājušies nostāsti vai mīti par viṇu kā personu, lai gan viņš ir starptautiski joprojām plaši zināma persona, savukārt R. Lamsters, kurš plašāk nav zināms, L,audonā joprojām ir spilgts atmiņu un nostāstu varonis. No otras puses, protams, var uzdot jautājumu, cik lielā mērā to, kurš palicis atmin̄ās, ietekmē laika atstatums?

R. Lamstera laiks muižā ir tik spilgts, ka tas lielā mērā aizēno kolektīvajā atmin̄ā faktu par muižas saistību ar Gideonu Ernestu fon Laudonu vai I. Rušmani, jāpiebilst gan, ka Pētersonu-Rušmaṇu dzimta prioritāri bija saistīta ar L,audonas muižu. Toces pusmuiža, to vēlāk pieminot, īpaši latviešu valodā iznākošā presē un vietējo L,audonas iedzīvotāju atmin̄ās, tiek pasniegta kā Lamstera īpašums. Ilustrācijai faktu uzslāņojumam kalpo Satversmes tiesas spriedums par Toces zemi, kurā iztirzātā problēma tika risināta vairākus gadus, tieši skarot gan L,audonas iedzīvotājus (īpaši bezzemniekus), gan Lamsteru gimeni. Par to tika runāts, rakstīts un lasīts.

Tātad šajā posmā pieminētie notikumi veicināja to, ka atmiṇas par fon Laudonu pārklājās ar Lamstera laika notikumiem. Par būtisku faktoru atmiṇu par fon Laudonu izzušanai jāuzskata svešinieku ienākšana un dzīve Tocē, pusmuižas vēsturiskā inventāra un apkārtnes ainavas izzušana, tādējādi pārtraucot dzimtas atmiṇu par dzīvesvietas vēsturi kontinuitāti. Kā norādījusi S. Ševaljē savā pētījumā par mājvietu nozīmi kolektīvajā un individuālajā atmiņā, cilvēki bieži savas mantas izmantoja kā "atcerēšanās balstus", proti, lietas kalpoja par fiziskām norādēm atmiṇu simulācijā (Ševaljē 1998, 76-79).

Tomēr pēdējo pāris gadu laikā, pateicoties gan fon Laudona dzīves izpētes interesentiem no Čehijas, gan Austrijas vēstniecības darbiniekiem, G. E. fon Laudonam un vina dzimtajai vietai uzmanību atkal sāka pievērst Ļaudonas pašvaldība, vēsturnieki un vietējie iedzīvotāji. Līdz tam faktiski vienīgais mēǵinājums izcelt fon Laudonu kā šì reǵiona vienu no slavenākajiem pārstāvjiem bija vācu okupācijas laikā veiktā Baznīcas ielas Rīgā pārsaukšana par Laudona ielu (Loudon Straße) (Rodatz 1941, Nr. 229).

Plāns 2017. gadā par godu fon Laudona 300 jubilejai L,audonā atklāt pieminekli palika neīstenots, taču ideja nav zudusi, tāpat kā no jauna atdzimusī interese par karavadoni un vin,a dzimto vietu. Tā lauj apgalvot, ka pēdējo gadu laikā no iepriekš minētajām personībām vislielākā interese atkal bijusi tieši par G. E. fon Laudonu, nevis R. Lamsteru vai I. Rušmani, vai citām ar Toces īpašumu saistītajām personām. Tātad redzams, ka laika gaitā dažādu iemeslu dēḷ mainās ar konkrētu vietu, šai gadījumā Toces pusmuižu, saistītais dominantais izpētes un cilvēku intereses objekts. 
Pēdējiem gadiem raksturīgi vēsturnieku, vēstures interesentu un vietējās pašvaldības pārstāvju mēǵinājumi atgriezt kolektīvajā atmiņā Toces pusmuižas un ar to saistīto personu vēsturi, ìpaši izceḷot G. E. fon Laudonu. Tomēr jāuzsver vēsturnieka un citu pētnieku kā informācijas pārnešanas starpnieku atbildība. Tās būs nevis pārmantotās, bet introducētās atminnas, tāpēc būtisks ir jautājums, ko un kāpēc ir nepieciešams pētīt un publicēt un kā to pasniegt, - vai šie pētījumi būs, piemēram, faktologiskais pamats vai daḷa no lielu popularitāti ieguvušās stāstniecības (Storytelling), kur parasti selektīvi akumulēti un tālāk tiek izmantoti tikai īpaši interesantie fakti, vai tas būs sākums nopietnākai konkrētas vietas (šajā gadījumā Toces/ L,audonas un ar to saistīto dzimtu) vēstures izpētei, kur mijiedarbībā ar citu vietu/dzimtu vēsturi būs iespējams izdarìt secinājumus par lokāli nozīmīgākiem notikumiem, piemēram, jau pieminēto agrāro reformu vai Vidzemes pusmuižu vēsturi.

\section{SECINĀJUMI}

T. s. atminu pētīšanas bums veicinājis vēsturnieku un sabiedrības interesi par individuālajām un kolektīvajām atmiņām un vēlmi tās no jauna iekḷaut savā un savas kopienas dzìvē.

Toces pusmuiža un ar to saistītā dzimtu vēsture maz saglabājusies dzīvajās atmiņās, radot atminu kontinuitātes vājināšanos un jaunu, stāstniecībai daudz saistošāku atminu uzslāņojumu, kuras kḷuvušas par dominantajām. To ietekmēja vairāki faktori, pirmkārt, īpašnieku un politisko varu vairākkārtēja maiņa, ienācēju, kam nebija nekādu dzimtas/senču atmiṇu piesaistes, kḷū̌sana par Toces pusmuižas iemìtniekiem, ar objektu un dzimtu vēsturi saistīto priekšmetu pazušana, konkrētu personu tēlu dominante cilvēku atminās.

Baltijas 19./20. gs. pētnieku prioritārā interese saistībā ar G. E. fon Laudonu ir bijusi par viņa un viņa dzimtas izcelsmi, uzvārda saistību ar apdzīvotas vietas "L̦audona" nosaukumu, nevis par personību un dzimto vietu (Toci). Joprojām nav vienprātības par fon Laudonu dzimtas izcelsmi, ierašanās laiku Livonijā (arī Tocē), dzimtas uzvārda saistību ar Ḷaudonas vietas nosaukumu.

Lai gan Toces pusmuižu kā G. E. fon Laudona un R. Lamstera dzīvesvietu varētu izmantot par atminu vietu stāstniecībā tūristu piesaistei, līdz šim tas nav darìts. Tomēr Toci iespējams pētìt un pasniegt, piemēram, kā fon Laudona dzimto vietu, Andrieva Niedras advokāta R. Lamstera dzīvesvietu, slavenu Latvijas laika zirgaudzētavu, 20. gs. 20. gadu agrārās reformas ìstenošanas vietu utt. Tāpēc var cerēt, ka iegūtā informācija palīdzēs atgriezt Toci un ar to saistîtos cilvēkus Latvijas vēstures atminu mozaīkā. 
Toces pusmuižas un ar to saistīto dzimtu un to pārstāvju vēstures izpētes uzsākšana radījusi virkni būtisku jautājumu, uz kuriem, balstoties uz šobrīd iegūtajiem materiāliem, vēl nav iespējams atbildēt. Piemēram, kā pati pusmuiža un vide tai apkārt mainījusies laika gaitā, vai ir saistība starp vietas "L̦audona" un fon Laudonu dzimtu nosaukumu sakritîbu, kur palicis pusmuižas inventārs utt. Līdz ar to var uzskatīt, ka šì publikācija un nolasìtais referāts, kas tika pieteikts kā pirmais posms no plašāka pētijuma par Toci un ar to saistītajām personām, pilnībā atspoguḷo pašreizējo situāciju, proti, ir iegūta vērtīga informācija, taču vienlaicīgi radušies daudzi būtiski jautājumi, uz kuriem šobrīd vēl nav iespējams sniegt atbildes, tāpēc pētījumu noteikti ir nepieciešams turpināt.

\section{SAĪSINĀJUMI}

BZIP - Brīvās Zemes Ilustrētais pielikums, Nr. 3, 21.03.1932.

Das Inland - Das Inland. Eine Wochenschrift für Liv-, Esth- und Curländische Geschichte, Geographie, Statistik und Litteratur. Herausgegeben von Dr. Carl von Rummer. Dorpat: Druck und Verlag von Heinrich Haakmann, 1846, Nr. 12, 19.03.1846.

LFK - http://garamantas.lv/lv/file/485836. Krājums: Latviešu folkloras krātuve, kolekcija: 21. zinātniskā ekspedīcija Dolē un Valkas rajonā, pierakstījis J. Strazdiņš. 1980.

LKV - Laudōns // Latviešu konversācijas vārdnīca, XII sēj., 22539. Rīga: A. Gulbis, 1935.

LNA LVVA - Latvijas Nacionālā arhīva Latvijas Valsts vēstures arhīvs

LS - Laukstrādnieks, 13.05.1926., Nr. 19.

MNM - Madonas novadpētniecības un mākslas muzejs

RV - Rīkojuma Vēstnesis

Šusters - Saruna ar Jāni Šusteru, 07.10.2017. Privātais arhīvs

TMV - Tieslietu Ministrijas Vēstnesis

\section{IZMANTOTIE AVOTI UN LITERATŪRA}

LNA LVVA (Zemkopības ministrijas Zemes ierīcības departaments (Rīga)), 1769-1721284, 1.-21. lp.

LNA LVVA (Ārlietu ministrijas Politiskais departaments), 2574-4-1294, 114. 1p.

LNA LVVA (Vidzemes guberņas Kamerālvalde. Muižu revīziju lietas. 1782-1914), 77-14-303, 1.-463. lp.

LNA LVVA (Vidzemes muižu plāni, kartes un apraksti), 7404-3-44, 1. lp.

LNA LVVA (Vidzemes, Kurzemes un Igaunijas muižu dokumenti), 6999-12-83, 1.-20. $1 \mathrm{p}$.

MNM 1997. gada kompleksā materiālu vākšanas ekspedīcija L̦audonas pagastā, Madonas novadpētniecības un mākslas muzejs. MNM Zinātniskais arhīvs.

MNM Plg 6943:5 [Muižkunga Rušmaņa dzimta].

MNM 20898 [Margaritas Rušmanes-Kalniņas fotogrāfija]. 
MNM 4232 [Jūlija Meldere ar mazbērniem].

MNM 34997 [23 vīru grupa L̦audonā pie mācītājmuižas vai luterāṇu baznīcas. Grupā arī R. Lamsters].

Agrāk un tagad. Cīna, 24.05.1941., Nr. 123.

Andreewa Needra teesaschana. Talsu Vēstnesis, 28.08.1924., Nr. 35, 2.

Atmina un vēsture. No antropoloğijas lìdz psiholoğijai. 1998. Rīga: N.I.M.S.

Bélina, P., Kaše, J., 2017. Generál Laudon - Slavný vojevůdce a pán na Bečvárech. Praha: Paseka.

Das Inland. Eine Wochenschrift für Liv-, Esth- und Curländische Geschichte, Geographie, Statistik und Litteratur. Herausgegeben von Dr. Carl von Rummer. Dorpat: Druck und Verlag von Heinrich Haakmann. 19.03.1846., Nr.12.

Der östreichische Generalissimus Feldmarschall Gideon Ernst v. Laudon. Ein Gedenkblatt von Paul Falck. Duna Zeitung, 25.01.1905., Nr. 15.

Eckardt, J. W. A., 1869. Ernst Gideon von Loudon. Baltische und russische Culturstudien [Kulturstudien] aus zwei Jahrhunderten. Leipzig, 183-272.

Firsts, J., Robina, I., Bunne, V., 2015. Atmiña kā kognitīvo spēju modula sastāvdala. Pieejams: http://w.w.w.journals.ru.lv/index.php/SIE/article/download/325/401 (skatīts (22.01.2018.)

Hagemeister, H., 1836. Materialien zu einer Geschichte der Landgüter Livlands. 2. Theil. Riga: Frantzen.

Hanovs, D., 2016. Kolektīvās atmiņas Eiropas kultūrtelpā: konflikti un iekḷaujošais potenciāls. Atminu kopienas: atceres un aizmiršanas kultūra Latvijā. Rīga: Zelta Grauds, $17-52$.

Hupel, W. A., 1788. Materialien zu einer liefländischen Adelsgeschichte: nach der bey der letzten dasigen Matrikul=Comission angenommenen Ordnung. Nebst andern kürzern Aussaßen etc. Riga: verlegts Johann Friedrich Hartknoch.

Janko, W. E., von, 1869. Das Leben des k. k. Feldmarschalls Gideon Ernst Freiherrn von Laudon. Wien.

Jēkabsons, Ē., Šcerbinskis, V. (sast.), 2007. Latvijas advokatūra. Zvērināti advokāti un zvērinātu advokātu paligi biogrāfijās 1919-1945. Biogrāfiska vārdnica. Rīga: Latvijas Valsts vēstures arhīvs.

Krsowitz von Taubmann F., 1789. Laudons Leben und Heldenthaten, 72.

Latvijā dzimis karavadonis plūc laurus Eiropā. Ilustrētā vēsture, 2008, februāris, 50-55.

Laudōns. Latviešu konversācijas vārdnīca, XII sēj., 1935. Rīga: A. Gulbja apgāds, $22539 \mathrm{sl}$.

Löwis of Menar K., 1904. Zur Genealogie des österreichischen Generalissimus Gideon Ernst Freiherrn von Laudon. Jahrbuch für Genealogie, Heraldik und Sphragistik. 1902. Mitau, 163-166.

Malleson, G., B., 1884. Loudon: A Sketch of The Military Life of Gideon Ernest, Freiherr von Loudon, Sometime Generalissimo of The Austrian Forces. London: Chapman and Hall, 243.

Orehovs, I., 2015. Ievads. Atmiña. Identitāte. Kultūra: zinātnisko rakstu krājums = Erinnerung. Identität. Kultur: wissenschaftliche Beiträge - Memory. Identity. Culture: collection of essays. [Rīga]: LU Akadēmiskais apgāds, 5-6.

Rodatz. Laudon. Friedrichs des Grossen bedeutendster Gegner im Kriege. Feldzeitung: Nachrichtenblatt einer Armee im Osten, 13.09.1941., Nr. 229.

Senāta principiels lehmums. Toces muischas ieskaitischana valsts zemju fondā. Latvis, 10.05.1925., Nr. 1084. 
Stryk, L., 1885. [Von:] Beiträge zur Geschichte der Rittergüter Livlands. Zweiter Teil, Der lettische Distrikt. Dresden: Albanus, 609 lk.

Ševaljē, S., 1998. Mājvieta kā muzejs: kolektīvā un individuālā atmiņa franču un britu mājās. Atmiña un vēsture. No antropoloǵijas lìdz psiholoğijai. Rìga: N.I.M.S., 76-79.

Tieslietu Ministrijas Vēstnesis, 01.12.1926., Nr. 11-12.

Transehe- [Roseneck], A., 1904. [Von:] Beiträge zur alten Geschichte der von Laudon. [In:] Jahrbuch für Genealogie, Heraldik und Sphragistik, 106-109.

\section{ATSAUCES UN PIEZĪMES}

${ }^{1}$ Madonas novadpētniecības un mākslas muzeja 1997. gada kompleksā materiālu vākšanas ekspedīcija L̦audonas pagastā.

${ }^{2}$ Ir pieejams plašs avotu un pētijumu klāsts par G. E. fon Laudona dzīvi pēc Vidzemes atstāšanas, īpaši par viņa militāro karjeru Austrijas armijā.

3 "Ľaudonai bijis cits nosaukums un tajā dzīvojis bagāts kungs vārdā Dons, kurš bijis l,oti l̦auns pret saviem cilvēkiem, nežēlīgi tos sodot par vismazāko pārkāpumu. Donu L̦audonas iedzīvotāji iesaukuši par l̦auno Donu. Vēlāk, kad Dons nomira, tad šo pilsētu arī nosauca - par L,audonu."

${ }^{4}$ Historiogrāfijā tiek uzsvērts, ka E. G. fon Laudons nav dzimis 1716. gada 1. oktobrī. Tas norāda uz nepareiza dzimšanas laika esamību atseviškās publikācijās (Falck 1905, Nr. 15; Malleson 1884, 11).

${ }^{5}$ Miris 1734. gadā, citviet - ka bijis dzīvs vēl 18. gs. 40. gados (Malleson 1884, 14).

${ }^{6}$ Atsevišķās publikācijās, piemēram, jau 1869. gadā, Jūlijs Ekards (Julius Wilhelm Albert von Eckardt) savā publikācijā "Ernst Gideon fon Laudon" kā pirmo vārdu minējis Ernstu/Ernestu (Eckardt 1869, 183-272), arī latviešu valodā (LKV 1935, 22539; Ilustrētā Vēsture, 2008, 50-55) iegājies kā pirmo vārdu lietot Ernests, taču tas nav pareizi. 


\title{
THE FORGOTTEN: GIDEON ERNST FON LAUDON AND TOCE ESTATE. THE STORY OF THE RETURN OF A MAN AND A SITE
}

\author{
LĪGA IRBE
}

MA in History

Email: irbe.liga@gmail.com

\begin{abstract}
The conference paper and the present publication is the first stage in a more extensive study about the fate of the Toce estate and people related to it. The story of Toce not only illustrates the process of falling into oblivion of people and places, the fading of memories and their subsequent calling back to life. It can also serve as a case-study for demonstrating processes of national importance, like the agrarian reform of 1920s and the related problems, or the fate of estates after the occupation of Latvia.
\end{abstract}

Keywords: Toce, L̦audona, Gideon Ernst von Laudon, Reinholds Lamsters, Toce estate, local history, family history, memory, the agrarian reform.

\section{SUMMARY}

2017 marked 300 years since the birth of the distinguished $18^{\text {th }}$ century military commander Gideon Ernst von Laudon at the Toce estate. However, both he and his birth place are little known in Latvia.

The so-called 'memory boom' has fostered the interest among historians and the public in individual and collective memories and the wish to reintroduce them into their lives as well as into the lives of their community. The used and available sources are essential for forming and sustaining of memories. The present paper analyses the sources on G. E. von Laudon, the Toce estate and the families related to the estate that are available at the State History Archives of Latvia and at Madona Regional History and Art Museum. It also lists the most significant works about G. E. von Laudon by $19^{\text {th }}-20^{\text {th }}$ century authors of the Baltic region.

As a rule, these publications generally focus on the genealogy of the von Laudon family and the origin of the family name rather than the history of G.E. von Laudon's birthplace or his personality. The historiography distinguishes among three versions of the possible relation between the von 
Laudon's family name and the place name "Laudona": 1) The family took the existing place name as their family name; 2 ) The place was named after the family name; and 3) The family name and the place name are identical by coincidence. To this day there is no consensus among researchers either about the connection between the family name and the place name or about the time when the family arrived in Livonia (or Toce).

The Toce estate is related to at least four families: the von Laudon family $\left(15^{\text {th }}\right.$ century $\left.-1840 \mathrm{~s}\right)$, the von Meiners family (1840s-1880s), the Petersons-Rusmanis (Peterson-Ruschmann) family (1880s-1920), and the Lamsters family (1920-?).

Little of the history of the Toce estate and the families related to it has been preserved in living memories. It contributes to weakened continuity of memories and memory stratification whereby the most recent memories (about R. Lamster) become dominant as they are found to be more captivating for storytelling. It has been facilitated by several factors: repeated changes of owners and political authorities, the settlement at the Toce estate of newcomers with no family or memory links to the place, the disappearance of artefacts related to the history of objects and families as well as the domination of certain persons in people's memories.

As the place of residence of G. E. von Laudon and R. Lamster, the Toce estate could be used in storytelling in order to attract tourists, which has not been done so far. However, the multitude of the potential focal points for studying and presenting Toce (e.g. as the birthplace of von Laudon, the residence of R. Lamster - the extraordinary lawyer of A. Niedra, a renowned stud farm in the interwar period, an example of the implementation of the agrarian reform and the related problems in 1920s, etc.) leaves room for hope that the collected information will enable returning Toce and people related to it into the mosaic of memories of Latvian history. 


\title{
KURZEME UN GOTLANDE: NOTURĪGU KULTŪRU KONTAKTU RAKSTUROJUMS VËLAJĀ DZELZS LAIKMETĀ
}

\section{LIENA SAKNE}

Mg. hist., Latvijas Nacionālā vēstures muzeja Uzskaites nodaḷas krājuma glabātāja

E-pasts: liena.sakne@Inum.lu

\begin{abstract}
ANOTĀCIJA
Kurzemes iedzīvotāji aizvēsturē uzturēja ilgstošus sakarus ar Gotlandes salu, to noturību galvenokārt noteica geogrāfiskie apstākḷi. Šiem kontaktiem veltīti plašāki pētījumi vidējā dzelzs laikmeta Grobiṇas arheoloǵiskā kompleksa kontekstā. Arheoloǵiskās liecības vēsta par intensīviem sakariem arī vēlajā dzelzs laikmetā un ievērojami plašākā regiionā. Gotlandiešu materiālā kultūra atstājusi ietekmi uz Kurzemē gatavotajiem priekšmetiem, īpaši rotām.
\end{abstract}

Atslēgas vārdi: gotlandieši, kurši, kultūru kontakti, rotas, vēlais dzelzs laikmets.

\section{IEVADS}

20. gadsimta laikā Latvijas arheoloǵiskajā pētniecībā ieviesās disproporcija attiecībā uz valsts austrumu un rietumu daḷu. To veicināja hidroelektrostaciju būvniecība uz Daugavas padomju okupācijas gados. Pēdējo desmitgažu laikā strauji pieaudzis pētniecības apjoms Kurzemes reǵionā, un tas devis materiālu jauniem pētījumiem. Par vienu no nozīmīgākajiem atklājumiem pēdējo gadu arheolog̣ijas zinātnē Latvijā noteikti minami skandināvu apbedījumi Lapsu senkapos pie Veckuldīgas pilskalna. Minētie senkapi gan nav vienīgās liecības par sakariem ar skandināviem, tostarp gotlandiešiem, un tās plašāk apskatītas šajā rakstā. Raksta mērḳis ir iezīmēt Kurzemes un Gotlandes salas iedzīvotāju sakaru pētniecības perspektīvas vēlā dzelzs laikmeta kontekstā. Savstarpējos kontaktus pētnieki aplūkojuši vairākkārt, tomēr pētījumu hronologiskais ietvars līdz šim bijis norobežots 
līdz ar Rimberta hronikā par Sv. Anskara dzīvi (Vita Anskarii auctore Rimberto) minētās Zēburgas (identificētas ar Grobiṇas Skārbaržkalnu) ieņemšanu 9. gadsimtā (Mugurēvičs 2015, 15-16). 20. gadsimta pirmajā pusē lielāko ieguldījumu Grobin,as apkaimes un Kurzemes pamatiedzīvotāju un skandināvu attiecību izpētē devis zviedru arheologs Birgers Nermans. B. Nermana atziṇas apkopotas divās monogrāfijās - "Saikne starp skandināviem un Austrumbaltiju vēlajā dzelzs laikmetā" un "Grobin,a-Zēburga. Izrakumi un atradumi”. Lai gan mūsdienās daḷa no B. Nermana atlasītā materiāla atzīstama kā vietējas izcelsmes, atsevišķām priekšmetu grupām koriĝ̣̄ts datējums un neapšaubāmi pieaudzis arheolog̣isko liecību apjoms, tomēr pētnieka veiktais priekšmetu izvērtējums un analoǵiju meklējumi bija savam laikam Latvijai novatoriski un joprojām ir aktuāli. Krievu arheologs Valērijs Petrenko Kurzemes arheologisiskajā ekspedīcijā daudzos Grobiņas apkārtnes pieminekḷus arheologisiski pētīja 20. gadsimta 80. gados un savas atziṇas apkopoja vairākos referātos (skat., piemēram, Petrenko 1990, 41-43) un grāmatā, kura iznākusi tikai 2012. gadā (Petrenko, Urtāns 2012). Grobiņas pētniecības vēsturi savā maǵistra darbā apkopojusi Arita Jume (Jume 2014). Skandināvu problemātiku Kurzemē vēlajā dzelzs laikmetā 20. gadsimta beigās un 21. gadsimta sākumā vairākās publikācijās risinājis arheologs Ēvalds Mugurēvičs, bet jaunu skatījumu uz šo jautājumu piedāvā Roberts Spirǵis, aplūkojot lībiešu un skandināvu bruṇrupuču saktu atradumus Latvijas teritorijā. Līdzšinējā pētniecībā nav pievērsta pastiprināta uzmanība dažādiem Skandināvijas reǵioniem, no kuriem cēlušies ievestie priekšmeti un Kurzemes ieceḷotāji.

Darba teritoriālie ietvari aptver kuršu un Baltijas somu apdzīvoto teritoriju vēlā dzelzs laikmeta beigās Rietumlatvijā un Rietumlietuvā jeb Kurzemi. Pētījuma gaitā identificētas materiālās kultūras liecības, kuras iespējams saistīt ar Gotlandes salu un datēt ar vēlo dzelzs laikmetu Latvijas teritorijā (9.-12. gadsimts). Rakstā aplūkotie priekšmeti glabājas Latvijas Nacionālajā vēstures muzejā, Ventspils muzejā, Kuldīgas novada muzejā un Talsu novada muzejā, senlietas no Rietumlietuvas teritorijas apkopotas pēc literatūras.

9.-12. gadsimts bija dinamisks laiks Ziemel̦austrumeiropā. Baltijas jūras rietumus apdzīvoja skandināvi - vikingi, kuru aktivitātes ietekmēja visu Eiropu un deva nosaukumu veselam laikmetam. Vēlajā dzelzs laikmetā Kurzemi ar Skandināviju vienoja ne tikai kopīgā Baltijas jūra, bet arī līdzības materiālajā kultūrā un, iespējams, arī citās arheoloǵiski grūti tveramās jomās. Vikingi nepārstāvēja kādu noteiktu etnisko grupu, turklāt ne visi vikingi bija skandināvi un ne visi skandināvi bija vikingi (Pašinskas 2010, 160). Došanās vikingos apvienoja gan militārās, gan tirdznieciskās aktivitātes, un tās sekmīgi varēja pāriet no vienas otrā. Mūsdienu Baltijas valstis un Krievijas teritorija kalpoja kā tranzìta zona tirdzniecībai ar Bizantiju un arābu 
reǵionu. T. s. "ceḷš no varjagiem uz griek̦iem" (arī "Austrumu ceḷš") veda no Skandināvijas uz Bizantiju pa upēm un ezeriem, savienojot Baltijas jūru ar Melno jūru (Hedenstierna-Jonson 2006, 97). Iemesli, lai dotos vikingos, bija atšķirīgi, tostarp izdevīgas situācijas izmantošana laupišanai, apstākḷi izcelsmes zemē - bads, politisks saspīlējums, izraidī̌ana no kopienas, nabadzība, zemes trūkums, arī indivīdu slavas un piedzīvojumu kāre (Roesdahl et al. 1992, 27). Vikingu laikmetā turpinājās jau iepriekšējos gadsimtos dibinātie tirdzniecības sakari un sirojumi. Labs piemērs šãdiem noturīgiem kontaktiem ir Skandināvijai geogrāfiski tuvais Kurzemes reǵions, ko skandināvi bija iepazinuši jau ilgi pirms vikingu braucienu sākšanās.

Latvijas teritoriju un to šķērsojušos tirdzniecības ceḷus apmeklēja ceḷotāji no plašām teritorijām, tomēr materiālās kultūras liecības ne vienmēr lauj noteikt konkrētus izcelsmes reǵionus. To ietekmē rotu un ieroču veidu plašā izplatība, kā tas konstatējams, piemēram, krāšņo bruņrupuču saktu gadījumā. Gotlandiešiem vidējā un vēlā dzelzs laikmetā raksturīga ìpatna materiālā kultūra, kas izteikti atškiriras uz pārējā reǵionā sastopamo kultūru fona. Balstoties uz materiālajām liecībām, konstatējams, ka intensīvākie sakari dzelzs laikmetā Kurzemes iedzīvotājiem bijuši ar gotlandiešiem. Skandināviskas izcelsmes priekšmeti Kurzemē varēja nonākt dažādu kontaktu rezultātā: ar mainas tirdzniecību, kā dāvanas starp elites pārstāvjiem, ja tie tika doti līdzi sievietēm, kas kā laupījums atvestas no citiem reǵioniem (Bliujienè 2008, 169).

\section{KONTAKTI KĀ ILGTERMIṆA PARĀDĪBA}

Senākie sakari ar gotlandiešiem Kurzemes iedzīvotājiem konstatējami jau bronzas laikmetā. Par to liecina t. s. "velna laivu" apbedījumi un Staldzenes depozīts. Laivas formas akmens krāvuma skandināvu apbedījumu vietas īpaši raksturīgas bronzas laikmetam un Gotlandes salai, kur atklāts vairāk par 300 šādu objektu (Vasks 2000, 35). Latvijā zināmas desmit "velna laivas", no kurām visas, izņemot vienu, grupējas nelielā teritorijā gar Rojas upi (Vasks 2003, 136). Staldzenes depozîts atrasts Staldzenes stāvkrastā pie Ventspils (Vijups 2002, 51-55). To veidoja vismaz 174 priekšmeti un to fragmenti ar kopējo svaru 5,6 kg. Staldzenes depozits pieder pie t. s. "lūžņu depozītiem", kuru veido nonēsāti, bojāti un speciāli salauzti priekšmeti, kas paredzēti pārkausēšanai. Depozīts, iespējams, komplektēts 7. gs. p. m. è. N̦emot vērā depozīta lokāciju, iespējams, šeit jārunā par depozìtu kā senas skandināvu kuǵa katastrofas liecinieku. Depozìta apjoms ir ievērojams ne tikai Latvijas teritorijas kontekstā, bet visā Austrumbaltijas reǵionā (Vasks, Vijups 2004, 15-17). Par kontaktiem turpmākajos gadsimtos pētījumi nav veikti, un par šo periodu kopumā Latvijas arheologiskais 
materiāls pagaidām ir skops, tomēr ticams, ka agrākie aizjūras kontakti netika pārtraukti; tāpat kā bronzas laikmetā Latvijas teritorijā bija nepieciešamas pastāvīgas krāsaino metālu piegādes rotu un rīku izgatavošanai.

Par Grobiṇas arheolog̣isko kompleksu līdz šim veikti dažādi pētījumi, un interese par šì reǵiona aizvēstures pieminekḷiem radās jau 18. gadsimta beigās, 19. gadsimta sākumā (Petrenko 1990, 41). Grobiṇas apkārtnē nelielā teritorijā izvietoti vairāki ar vidējo dzelzs laikmetu datējami līdzenie un uzkalniṇu kapulauki, kuros apbedīti gan skandināvu iecel̦otāji, gan vietējie kurši. Apbedījumi liecina gan par iecel,otājiem no Skandināvijas pussalas, gan gotlandiešiem. Gotlandiešu iecel̦otāju apbedījumi atklāti Priediena II senkapos, datēti ar laiku no 650. līdz 800. gadam', no kurienes nāk arī unikālais akmens stēlas - t. s. "bilžakmens" - atradums; bilžakmeņi raksturīgi tieši Gotlandes salai (Petrenko, Urtāns 2012, 57). Par gotlandiešiem liecina arī atsevišksas senlietas no Grobin,as Smukumu (Rudzukalnu) senkapiem. Pagaidām vienīgais pētītais skandināvu kapulauks ārpus Grobiņas reǵiona ir Lapsu senkapi, kur atsegti divu sieviešu un četru vīriešu apbedījumi. Līdzi doto kapa piedevu vidū bija divas lāčgalvu saktas, kas raksturīgas gotlandietēm, kā arī rotas, kas tipiskas Skandināvijas cietzemes iedzīvotājām (Lūsēns 2016, 58-60). Senkapi datēti ar 760.-880. gadu, kas liecina, ka to izmantošana vismaz daḷēji pārklājās ar Grobiṇas pastāvēšanu. Atsevišḳi savrupatradumi arī citviet Kurzemē l,auj runāt par sakariem ar gotlandiešiem vidējā dzelzs laikmetā. Līdz kuršu ekspansijai, kas tiek datēta ar aptuveni 11.-12. gadsimtu, Kurzemes pussalas lielāko dalı apdzīvoja Baltijas somi, kas, bez šaubām, arī uzturēja sakarus ar ieceḷotājiem un tirgotājiem. Hronoloǵiski kuršu ekspansija sakrīt ar vikingu aktivitātes perioda beigām un kuršu ietekmes palielināšanos Baltijas jūrā, tomēr vismaz pagaidām tieša šo procesu saistība nav konstatējama.

Gotlandi un Kurzemi šḳir pavisam neliels attālums, kas laikā, kad galvenā transporta maǵistrāle bija ūdenscel̦š, bija daudz vieglāk pārvarams nekā meža biezokņi, kas noklāja lielāko daḷu mūsdienu Latvijas teritorijas. Šis jūrascel̦š neprasīja īpašas kuğubūves prasmes. Buras, kas ievērojami uzlaboja kuǵošanas spējas, skandināvu kuǵiem parādījās ap vidējo dzelzs laikmetu (Roesdahl 2016, 86). Salīdzinot ar Gotlandes materiālu, vēlā dzelzs laikmeta Skandināvijas pussalas izcelsmes importa priekšmeti Kurzemē atrasti mazākā skaitā, tie arī grūtāk atšķirami no vietējiem ražojumiem. Zviedru, norvēg̣u, dāṇu, arī islandiešu (Egila Skalagrimsona) piedzīvojumi Kurzemē l,oti plaši aplūkoti rakstītajos avotos - sāgās un hronikās, tomēr avoti, kas vēsta par saikni ar Gotlandes salu, ir pavisam skopi un par vēlo dzelzs laikmetu informē pastarpināti. Indriķa hronika parāda, ka Gotlande bija kḷuvusi par bāzes nometni un pieturpunktu kristīgajai misijai ceḷā uz Livoniju, tomēr sala saglabāja arī savu tirdzniecības centra funkciju, un no tās uz Livoniju devās tirgotāji. Ticams, ka kuršu un igauṇu sirošana Gotlandes 
tuvumā, kas minēta hronikā, nozīmēja arī tirgošanos salā, tāpat kā vikingu laikmetā strikti nenodalot tirdzniecību no piratērijas. Gotlandes lielā ietekme uz Baltijas tirdzniecību saistìta, pirmkārt, ar nelielo fizisko attālumu starp Gotlandi un Rietumlatviju, ko labos laika apstākḷ os varēja šḳērsot 1,5-2 dienu laikā (Gunnarsson 2013, 17), otrkārt, ar Birkas kā tirdzniecības centra lomas samazināšanos no 11. līdz 13. gadsimtam, un Gotlandes tirgotāji aizpildīja šo vakuumu (Peel 2015, xx). Salas nozīmību netieši pierāda pāvesta Gregorija IX vēstules Linkopingas bīskapam, Visbijas draudzes vadītājam Gotlandē 1229. gadā. Tajās pieprasīts pārtraukt ieroču, zirgu, kuğu un ēdiena tirdzniecību pagāniem, lai ar gotlandiešu palīdzību vēl nekristīgās zemes nevairotu savus pretošanās spēkus krustnešiem (Magnusson 1995, 69).

\section{SAKARI MATERIĀLAJĀ KULTŪRĀ}

Galvenais avots gotlandiešu un Kurzemes iedzīvotāju kontaktu izpētē ir arheologiskais materiāls. Liela Kurzemē ievesto priekšmetu grupa ir rotas. Bieži noteikt rotas izcelsmi ir sarežğîti, jo, kā jau minēts, rotu tipi vēlajā dzelzs laikmetā bija raksturīgi plašiem reǵioniem. Tādu rotu kā pakavsaktas, vīti kaklariņ,i un zvērgalvu aproces izplatība norāda uz ciešajiem kontaktiem starp Baltijas jūras austrumu piekrasti un skandināviem.

No Kurzemē atrastajām vēlā dzelzs laikmeta sieviešu rotām ar Gotlandes produkciju saistītas lāčgalvas saktas un kārbiņsaktas, un zivju galvas piekariņš. Lāčgalvas saktas nēsātas pa pāriem sieviešu apgeērba saspraušanai un pildīja tādu pašu funkciju kā plašāk pazīstamās bruņrupuču saktas. Lāčgalvas saktas (1. attēls, a), kombinējot ar kārbiņsaktām, veidoja gotlandiešu sievietes rotu raksturīgāko komplektu. Kurzemē divu dažādu saktu pāris atrasts Lapsu skandināvu senkapos (KNM 42441, 42442), bet atsevišķa sakta - Ventspilī kā savrupatradums būvdarbu laikā (Maiznieku ielā 11, VVM 30141). Visas saktas datējamas ar 9. gadsimtu. Lāčgalvas saktas atrastas arī jaunatklātajos skandināvu Kundu senkapos Kuldīgas novadā. Nedaudz lielākā skaitā Kurzemē atrastas kārbiṇsaktas (1. attēls, b); vairākas ar vēlo dzelzs laikmetu datējamas saktas atsegtas Grobinas Smukumu kapulaukā (piemēram, A 8879:2), saktas fragments atrasts Lapsu senkapos (KNM PlgL 3179), bet vēlāka, ar 10. gadsimtu datējama sakta - Tārgales pagastā pie Dokupes (VVM 30741).

Ārpus Gotlandes abu tipu saktas atrastas reti un vēl retāk vienā apbedījumā. Lielākoties rotu komplekti ir jaukti, un tajos skandināvu izcelsmes priekšmeti veido tikai nelielu dạı no kapa inventāra. Suzanna Tedēna uzskata, ka importa rotas apbedījumos liecina par sievieti, kas pārstāv augstu sociālo slāni, īpaši attiecībā uz ārpus Gotlandes reti sastopamo kārbiņsaktu 


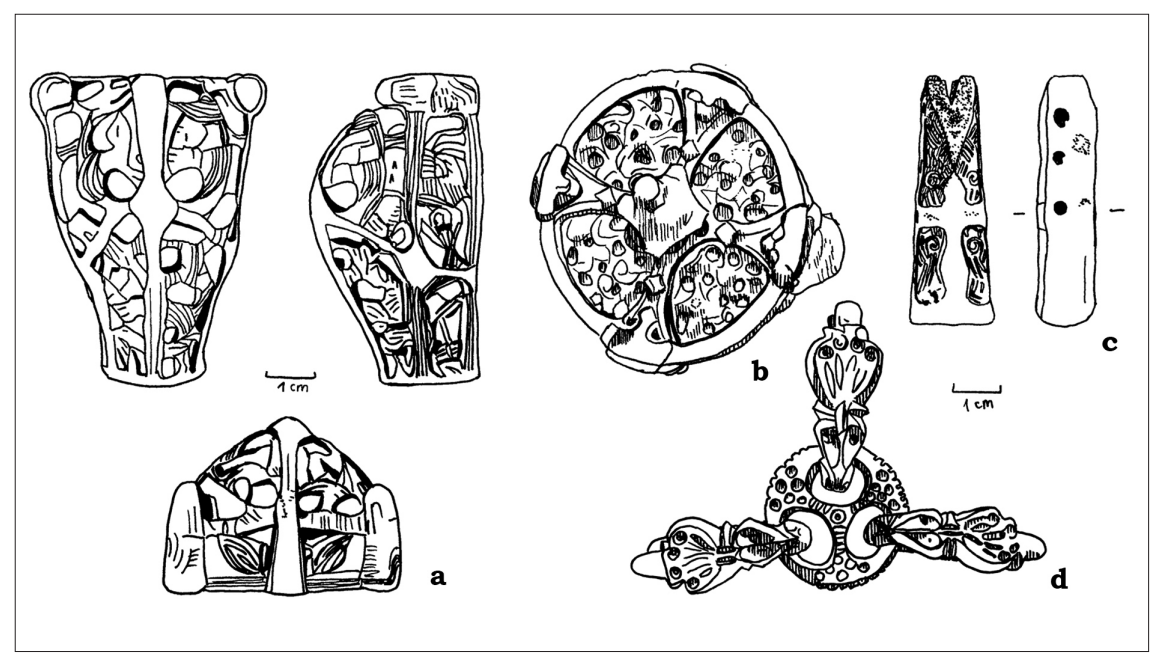

1. attēls. No Gotlandes importētas senlietas Kurzemē: $a$. Lāčgalvu sakta, Lapsu senkapi, Kuldīgas novads, Padures pagasts, KNM 42442; b. Kārbiṇsakta, savrupatradums pie Dokupes, Ventspils novads, Tārgales pagasts, VVM 30741; c. Zivju galvas piekariņš, savrupatradums, Kuldīgas novads, Ivvande, A 731; d. Zvērgalvu formas apkalums, savrupatradums, Lejnieku (Sanderu) senkapi, Grobinas novads, Gaviezes pagasts, A 13787:1 (autores zīmējums).

nēsātājām (Thedéen 2012, 60-78). Lapsu senkapos atrasts gan lāčgalvas saktu pāris, gan bruņrupuču saktas, gan kārbiņsakta (savrupatradums), bet ne vienā apbedījumā (Lūsēns 2016, 60). Tikpat izteikti gotlandisks ir zivju galvas piekariņš (1. attēls, c), kas atrasts İvandē (A 731). Tā forma atgādina zivs asti vai galvu, vēlāko periodu piekariņiem raksturīgais krusta motīvs tiek skaidrots kā kristīgā simbolika, apzīmējot Jēzu Kristu. İvandes piekariņam krusts stilizēts, atainojot cilvēka siluetu, un papildināts ar četrām spirālēm, piekariņa gali ir nolūzuši. Šie piekariņi tikuši valkāti gan atsevišķi, gan daudzi kopā, veidojot kaklarotu, un vēlāk izmantoti arī saktu vietā. Īvandes piekariņa sānos izurbtie caurumiņi liecina par nēsāšanas veidu, apvienojot vairākus zivju galvas piekariņus kopā. Gotlandē šādi salīdzinoši vēli piekariņi tiek datēti visai plaši - no 950. līdz 1150. gadam (Melander 2014, 49-50).

Uzskatāmi kontakti ar skandināviem ietekmējuši Kurzemes rotu attīstību, ieviešot zvērgalvu stilu kuršu saktās un aprocēs. Zoomorfā stila rotas Rietumlatvijā parādījās 5.-6. gadsimtā, bet stila lokālā versija attīstījās 8.-9. gadsimta laikā. Baltu rotās zvērgalvu stils tika geometrizēts (Bliujienè 2001, 222). Baiba Vaska saskata saistību starp zvērgalvas aprocēm Grobiṇas Smukumu un Porānu kapulauka materiālā, kuru izcelsme saistāma ar gotlandiešiem, un vēlākajām kuršu aprocēm. Par saistību liecina aproču formu varianti, kuri gan gotlandiešu, gan kuršu aproču grupām ir vienādi: 
masīvas un gludas aproces, tordētas vai vītas aproces un lentveida aproces ar trīsstūrainu, pusaploces vai noplacinātu šḳērsgriezumu (Vaska 1994, 113, 118). Savukārt Armands Vijups piel̦auj, ka arī pakavsaktas ar vāḷu galiem, kuru pirmparaugi atrodami skotu un ìru arheoloǵiskajā materiālā, Austrumbaltijā nonākušas caur Gotlandi (Vijups 1998, 44-46).

No vīriešu rotām minamas ažūrās zvērgalvu saktas. Tās Gotlandē un arī Salaspils Laukskolas kapulaukā atrastas vīriešu un pusaudžu zēnu apbedījumos, bet kuršu apdzivotajā teritorijā rotas atrastas kā savrupatradumi, viena Gramzdas Upī̌sos un divas Palangā. Iespējams, par lokālu ažūrās saktas atvasinājumu uzskatāms eksemplārs no Alsungas Kalniṇu 30. kapa (A 11732:5). Plašāk Kurzemē ieviesušies vīriešu jostu un zirgu iemauktu apkalumi zvērgalvu formā (1. attēls, d). Tie radīti Gotlandē, bet Kurzemē pakāpeniski notikusi apkalumu stilizācija, tos geometrizējot. Vēlākie zvērgalvu apkalumi konstatēti Kazdangā un Talsu Vilkumuižas ezerā, kur atsevišķiem eksemplāriem nojaušama tikai aptuvena saistība ar apkalumu

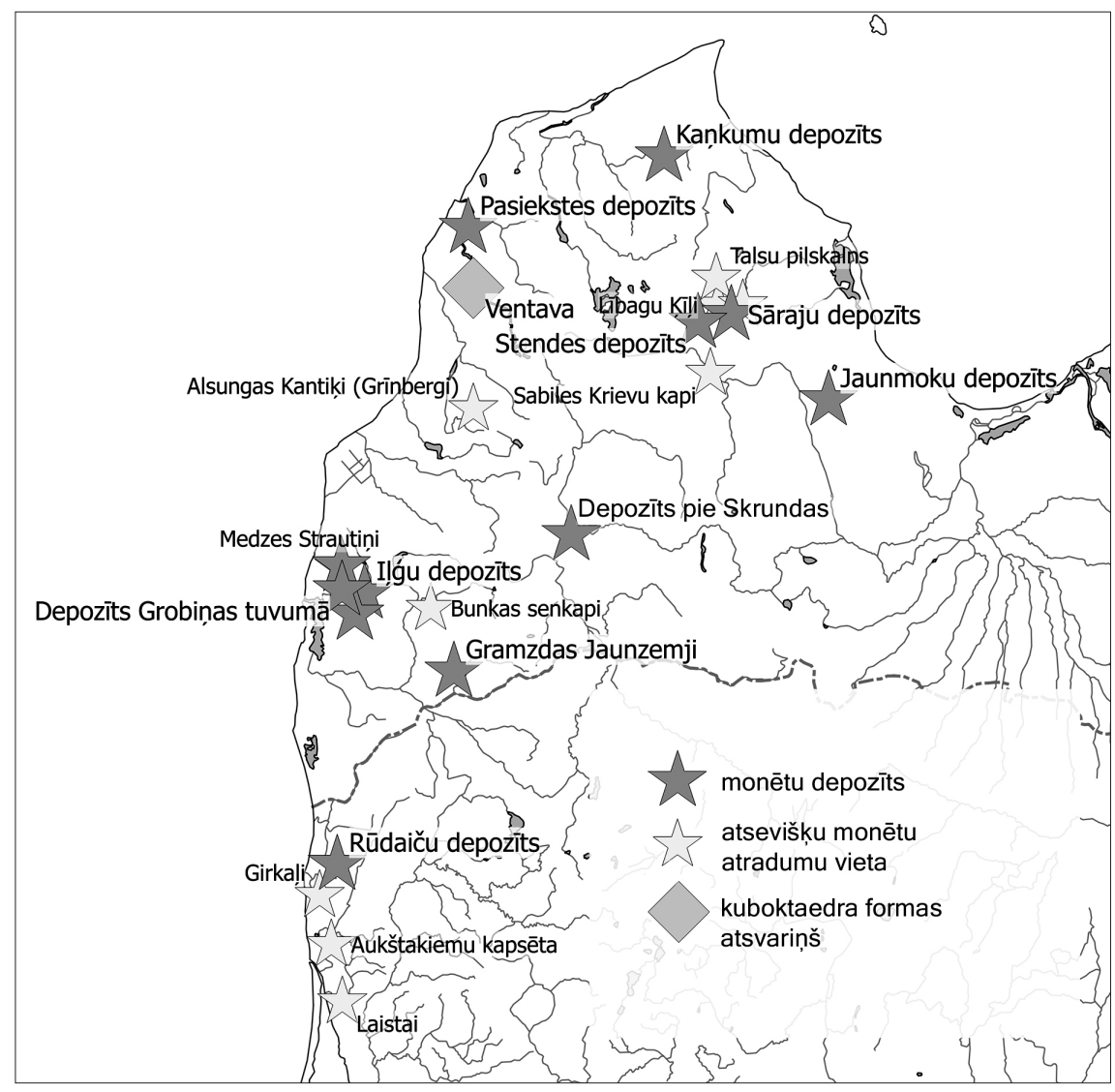

2. attēls. Arābu dirhēmu atradumi Kurzemē 9.-12. gadsimtā. 
3. attēls. Kuboktaedra formas atsvariňš, savrupatradums, Ventspils novads, Vārves pagasts, Zūras, VVM 30786 (autores zìmējums).

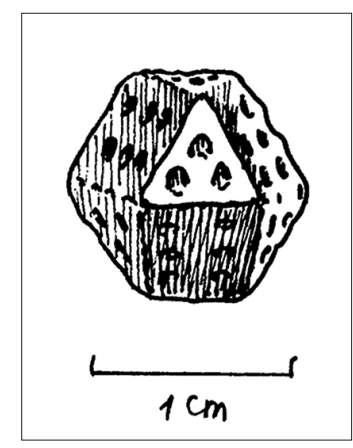

pamatformu (piemēram, savrupatradums Kazdangā, A 1196, Vilkmuižas ezers, A 8572:7).

Ievērojama Gotlandes materiālās kultūras ietekme vērojama tuvcīṇas ieroču sakarā. Zobenu imports sācies aptuveni 9. gadsimtā un kuršu teritorijas Latvijas daḷā saistīts ar skandināvu apdzīvoto Grobinas apkārtni. Plašākais zobenu klāsts apbedījumos sastopams no 10. līdz 12. gadsimtam. Caur Gotlandi Kurzemē nonāca gan Rietumeiropas Piereinas reǵiona zobeni (Baronas 2007, 360-361), gan arī pašu Gotlandes kalēju izgatavotie zobeni (Magnusson 1995, 68). Ieroču formās Baltijas jūras piekrastē novērojamās atškirīibas ir nelielas, kas apgrūtina to izgatavošanas vietu lokalizāciju, tomēr ticams, ka arī citi ieroču veidi, īpaši tie, kuru izgatavošana prasīja augstu amatnieku meistarību, piemēram, damascētā tērauda uzmavas šķēpu gali (Anteins 1976, 69), ievesti tieši no Gotlandes. Jau minēts, ka ieroču importam no Gotlandes salas bija īpaša nozìme 13. gadsimtā vietējo tautu cīṇās pret krustnešiem.

Gotlandes salai bija galvenā loma arābu zemju izgatavoto priekšmetu importā Kurzemē. Austrumu imports visā Baltijas jūras reǵionā parādījās 9. gadsimtā. Kurzemē atrasti septiṇi dirhēmu depozīti un trīs jauktie - austrumu un rietumu monētu - depozīti, bet kuršu apdzīvotajā teritorijā Lietuvā zināmas četras monētu atradumu vietas un depozìts (2. attēls). Arābu imports pa Volgu nonāca Staraja Ladogā, no kurienes tika aizvests uz Gotlandi, un tikai neliela daḷa no tā nonāca baltu teritorijās. Iespējams, nelielais monētu atradumu skaits skaidrojams ar monētu pārkausēšanu dārgmetāla izmantošanai rotu izgatavošanā (Bliujienè 2008, 169). Īpašs austrumu eksporta priekšmets ir kuboktaedra formas atsvarinšs ar iegravētiem punktiem (3. attēls), kas atrasts Ventas krastā pie Ventavas (VVM 30786). Tas sver 3,93 gramus, kas atbilst dirhēma svaram. Kaupangā (mūsdienu Norvēgija), kur atrasti vairāk nekā 40 šādu priekšmetu, tie datēti ar 9. gadsimta otro pusi - 10. gadsimta sākumu (Pedersen 2008, 123, 148, 155). Kuboktaedra atsvariņa atradums ir tieša liecība par tirdzniecību ar importētiem dārgmetāliem, kuru galvenais "piegādātājs" reǵionā bija skandināvu tirgotāji. 


\section{SECINĀJUMI}

Apkopojot pieejamo arheolog̣isko materiālu, jāsecina, ka Gotlandes tirgotājiem bija galvenā loma Kurzemes iedzīvotāju apgādāšanā ar importa produkciju vēlajā dzelzs laikmetā. Pagaidām nepilnīgi pētīi pretējie procesi un Kurzemes importa priekšmetu atradumi salā. Dāniela Gunnašona (Daniel Gunnarsson) aplūkotie Austrumbaltijas importa priekšmetu atradumi grupējās ap ostu vietām (Gunnarsson 2013, 50-52, 57). Nepabeigtu krustadatu pusfabrikātu atradumi salā liecina, ka gotlandieši ražoja daḷu produkcijas tieši Austrumbaltijas tirgum, jo šādiem izstrādājumiem nebija pielietojuma vietējo sieviešu apǵērbā. Zināmi arī divi apbedījumi ar pilnu Austrumbaltijai raksturīgu rotu komplektu, kas saistāmi ar baltu sievietēm. Kopumā Gotlandē atrastas 18 krustadatas un trīsstūradatas, Dānijā - ap 10, Zviedrijā - aptuveni četras (Jansson 1995, 86-89). Lēna Tunmārka-Nīlena norāda, ka minētās pakavsaktas Gotlandē parādījušās tikai 10. gadsimta sākumā, turklāt identiskas tām, kas nēsātas Austrumbaltijā, un tikai vēlāk attīstijjušās vietējās gotlandiskās formas. Tas liecina, ka šis rotu veids varētu būt ieviesies no Austrumbaltijas (Thunmark-Nylén 2000, 173). Par ievestām tiek uzskatītas, piemēram, pakavsaktas ar atpakal atliektām zvērgalvām. Šì tipa pakavsaktas ir lielisks piemērs Gotlandes un Kurzemes iedzīvotāju kultūru ciešai sasaistei: no skandināviem Kurzemes rotās ieviestais zvērgalvu stils, tālāk attīstīts gatavu izstrādājumu veidā, nonāca atpakal, Gotlandē.

Skopās rakstītās ziṇas liecina gan par piratēriju, gan tirdzniecību, un, lai arī arheolog̣iskais materiāls liecina par intensīviem maiņas procesiem starp Kurzemi un Gotlandes salu, pagaidām Kurzemē nav liecību par gotlandiešu apmešanos reǵionā pēc 9. gadsimta, kad atstāts Grobiņas reǵions un Ventas lejtece.

\section{SAĪSINĀJUMI}

A - Latvijas Nacionālā vēstures muzeja Arheoloğijas departamenta kolekcijas šifrs KNM - Kuldīgas novada muzeja kolekciju šifrs

VVM - Ventspils muzeja kolekciju šifrs

\section{IZMANTOTIE AVOTI UN LITERATŪRA}

Anteins, A., 1976. Melnais metāls Latvijā. Rīga: Zinātne.

Baronas, D., 2007. Prekyba vikingų laikais. Lietuvos istorija II tomas. Geležies amžius. Vilnius: Baltos lankos, 353-366.

Bliujienė, A., 2001. Baltų zoomorfinis stilius. Lietuvos Archeologija, 21, 205-222. 
Bliujienè, A., 2008. Trade, Warfare, Looting and Hoarding: Attributes of Viking Age Contacts Across the Baltic Sea. Muižnieks, V., sast. Pētijumi kuršu senatnē: rakstu kräjums. Rīga: Latvijas Nacionālais vēstures muzejs, 167-179.

Gunnarsson, D., 2013. The distribution of Bronze artefacts of Viking Age Eastern Baltic types discovered on Gotland: Iron Age Networks and Identities. MA thesis. Gotland University.

Hedenstierna-Jonson, Ch., 2009. Social and political formations in the Scandinavian areas, 8th-10th century. The martial perspective. Territorio, Sociedad y Poder, 2, 89-104.

Jansson, I., 1995. Dress Pins of East Baltic Type Made on Gotland. Jansson, I., ed. Archaeology east and west of the Baltic: papers from the Second EstonianSwedish Archaelogical Symposium, Sigtuna, May 1991. Stockholm: Department of Archaeology, Stockholm University, 83-90.

Jume, A., 2014. Skandināvi Grobinas un tās apkārtnes arheologiskajā materiālā 7.-9. gadsimtā. MA thesis. Latvijas Universitāte.

Lūsēns, M., 2016. Jauns skandināvu kapulauks Kurzemē. Arheologu pētijumi Latvijā 2014-2015. Rīga: Nordik, 58-62.

Magnusson, G., 1995. Iron Production, Smithing and Iron Trade in the Baltic during the Late Iron Age and Early Middle Ages (c. 5th-13th Centuries). Jansson, I., ed. Archaeology East and West of the Baltic: papers from the Second EstonianSwedish Archaelogical Symposium, Sigtuna, May 1991. Stockholm: Department of Archaeology, Stockholm University, 61-70.

Melander, V. N. L., 2014. Det obetydliga: om fiskhuvudformiga hängen, sociala praktiker och förändring, 600-1200 e. Kr. The Insignificant: Fish-head pendants, Social structures and Change, 600-1200 AD. MA thesis. Uppsala universitet.

Mugurēvičs, $\overline{\mathrm{E}}$., 2015. Rietumeiropas hronikas par baltu apdzīvotām zemēm: 9.-13. gadsimta hroniku fragmenti, tulkojumi, komentāri. Rīga: Latvijas vēstures institūta apgāds.

Nerman, B., 1929. Die Verbindungenzwischen Skandinavien und dem Ostbaltikum in der jüngeren Eisenzeit. Stockholm: På Akademiens Förlag.

Nerman, B., 1958. Grobin-Seeburg: Ausgrabungen und funde. Stockholm: Almqvist \& Wiksell.

Pašinskas, V., 2010. Develpoment of maritime human resources and education on basis of Balts' shipping history. Proceedings of $12^{\text {th }}$ International Conference "Maritime Transport and Infrastructure - 2010". Rīga: Latvijas Jūras akadēmija, 158-163.

Pedersen, U., 2008. Weights and balances. SKRE, D., ed. Means of Exchange. Dealing with Silver in the Viking Age. Kaupang Excavation Project Publication Series. Vol. 2. Norske Oldfunn XXIII. Ârhus: Aarhus University Press, 119-195. Pieejams: https:// www.academia.edu/5010903/Weights_and_balances (skatits 01.12.2017.)

Peel, C., ed., 2015. General introduction: Gotland's medieval historical background. Guta Lag and Guta Saga: The Law and History of the Gotlanders. London: New York: Routledge, xvii-xxii.

Petrenko, V., 1990. Assemblage of Archaeological Monuments at Grobina in the Light of Recent Investigations. Apala, Z., Mugurēvičs, Ē., Ronis, I., red. Austrumbaltijas un Skandināvijas kontakti agrajos viduslaikos: starptautiskās konferences (Rìga, 1990. 23.-25. X) referātu tēzes. Rīga: Latvijas Zinātṇu akadēmijas Vēstures institūts, 41-43.

Petrenko, V., Urtāns, J., 2012. Grobinas arheologiijas pieminekḷi. Rīga: Nordik.

Roesdahl, E., 2016. The Vikings. 3rd ed. Penguin Books. 
Roesdahl, E., Wilson, D. M., eds., 1992. From Viking to Crusader: The Scandinavians and Europe 800-1200. New York: Rizzoli.

Thedéen, S., 2012. Box Brooches beyond the Border Female Viking Age Identities of Intersectionality. Back Danielsson, I., M., Thedéen, S., eds. To Tender Gender: The Pasts and Futures of Gender Research in Archaeology. Stockholm Studies in Archaeology 58. Stockholm: Stockholm University, 61-81. Pieejams: https://www. diva-portal.org/smash/get/diva2:571447/FULLTEXT01.pdf (skatits 20.11.2017.)

Thunmark-Nylén, L., 2000. Some Notes on the Contacts Between Gotland and the East Baltic Area. Archaeologia Baltica, 4, 173-180.

Vaska, B., 1994. Ornaments uz kuršu aprocēm ar zvērgalvu galiem. Arheologiija un etnogräfija, 17, 113-119.

Vasks, A., 2000. Bīlavu "velna laivas" izrakumi un rekonstrukcija 1999. gadā. Arheologu pētijumi Latvijā 1998. un 1999. gadā. Rīga: LU Latvijas vēstures institūts, 35-46.

Vasks, A., 2003. Rietumlatvija bronzas laikmeta sakaru lokā. Arheoloğija un etnogrāfija, 21, 132-140.

Vasks, A., Vijups, A., 2004. Staldzenes bronzas laikmeta depozits. Staldzene Bronze Age Hoard. Rīga: Ventspils muzejs.

Vijups, A., 1998. Latvijas XIII-XVII gs. pakavsaktas kā arheologiskais avots (tipoloğiskā analizze). Promocijas darbs. Latvijas Universitātes Vēstures un filozofijas fakultāte.

Vijups, A., 2002. Staldzenes bronzas laikmeta depozīts. Arheologu pētijumi Latvijā 2000. un 2001. gadā. Rīga: LU Latvijas vēstures institūts, 51-55. 


\title{
COURLAND AND GOTLAND: CHARACTERISATION OF THE LONG LASTING CULTURAL RELATIONS IN THE LATE IRON AGE
}

\section{LIENA SAKNE}

MA in History, Collection Manager at the National History Museum of Latvia

Email: liena.sakne@Inum.lu

\begin{abstract}
During prehistory the inhabitants of Courland had long lasting relations with Gotland, mainly due to the geographical conditions. So far research has mainly focused on the archaeological site of Grobina during the Middle Iron Age. However the artefacts tell about intense relations during the Late Iron Age and in a much larger territory. The material culture of Gotland has left an impact on artefacts made in Courland.
\end{abstract}

Keywords: inhabitants of Gotland, Couronians, cultural relations, jewellery, the Late Iron Age.

\section{SUMMARY}

During the Late Iron Age (in modern Latvian historiography dated from the $9^{\text {th }}$ to the $12^{\text {th }}$ century $A D$ ), the western part of the Baltic Sea was inhabited by the Scandinavians - also known as Vikings, whose military and trade activities covered a vast region. However, the relations between Scandinavia and Courland developed during much earlier times, especially contacts between Courland and the island of Gotland. In the period of prehistory, the waterway between Gotland and Courland was less dangerous and took less time than land roads and has been crossed at least since the Bronze Age, as evidenced by the stone ship burials in Courland and the Staldzene hoard. The next episode in these relations is linked with Middle Iron Age burial sites in Grobina district where people both from Gotland and Scandinavian Peninsula have been buried. Outside this district the only known Scandinavian burial site is Lapsas burial field by the river Venta, next to Veckuldiga hillfort, which was in use in the Late Iron Age. Another site was discovered near Kunda hillfort in 2016. A few Gotlandic stray finds dated to the Middle Iron Age suggest that the relations covered a much larger region than previously thought and linked the Gotlanders not 
only with the Couronians but also with the Baltic Finns. However, there is no evidence of any Gotlandic settlement in Courland after the $9^{\text {th }}$ century.

The written sources have only a few mentions of the relations between Gotland and Courland. The Chronicle of Henry of Livonia suggests that the island of Gotland had become a base camp for the conquest of the would-be Livonia, while still maintaining the role of a trading centre. It is also testified by the letters of Pope Gregory IX to the Bishop of Linkoping demanding to cut off all trade with the East Baltic tribes in order to decrease the defence capacity of the heathens. The island's role as a trading centre especially grew in the period from the $11^{\text {th }}$ to the $13^{\text {th }}$ century thanks to the decline of Birka.

During the Late Iron Age the inhabitants of Gotland had quite distinctive material culture that can be easily distinguished from the Couronian artefacts. Animal head brooches, box brooches and a fish head pendant have been found in Courland, dated to the $9^{\text {th }}-10^{\text {th }}$ century. A specific box brooch with geometrized ornament from Grobina's Smukumi burial field shows influence of the local Couronian tribe. It is believed that the shape of the Couronian animal head brooches and bracelets as well as the penannular brooches with club-shaped terminals have come from Gotland. Also introduced from Gotland are animal head shaped bindings (used both as a part of horse bridles and of men belts) which during the Late Iron Age evolved into local Couronian geometric shapes. A part of the imported double-edged swords reached the Eastern Baltic shores through Gotland and some of them probably were made on the island. Gotland held a central role in the trade with the East, supplying the region with silver dirhems and other precious metals. Unique to the Eastern Baltic is a cuboctahedron-shaped weight with engraved dots, dated to the late $9^{\text {th }}-$ early $10^{\text {th }}$ century. Unfinished decorative pin finds in Gotland suggest that the Gotlanders may have produced jewellery specially for the Eastern Baltic region, since pins were not part of the Gotlandic women's garment. 


\title{
LIESINĀTĀJI VĒLĀ BRONZAS LAIKMETA KERAMIKAS TRAUKU VEIDMASĀ: PRAKTISKĀ UN SIMBOLISKĀ NOZĪME
}

\author{
VANDA VISOCKA
}

Mg. hist., zinātniskā asistente arheoloğijā, LU Vēstures un filozofijas fakultāte

E-pasts: vanda.visocka@lu.lv

\begin{abstract}
ANOTĀCIJA
Pētījums veltīts liesinātājiem un to piejaukšanas tehniskajiem un simboliskajiem aspektiem vēlā bronzas laikmeta pilskalnu keramikas materiālā Latvijas teritorijā. Par liesinātājiem dēvē dažādus cilvēka pievienotus materiālus keramikas veidmasai (sasmalcināti granītiskie ieži, šamots, organika u. tml.). Lai noskaidrotu liesinātāju tendences, pētījumā izmantotas divas izpētes metodes - vizuālās (makroskopiskās) analīzes un keramikas petrogrāfiskā analīze. Savukārt, lai izzinātu iespējamos simboliskos iemeslus liesinātāju pievienošanai, kā salīdzinošais materiāls izmantoti etnoarheoloǵiskie dati. Makroskopiski analizētas deviṇu pilskalnu keramikas kolekcijas. Savukārt petrogrāfiski analizēti 102 keramikas plānslīpējumi. Visos analizētajos pilskalnos liesinātāju pievienošanas tendences ir ar līdzīgām iezīmēm. Dominējošais liesinātāju veids ir granīts, retāk sastopams šamots vai augu atliekas. Visi konstatētie liesinātāji atvieglo keramikas izgatavošanu (tā neplaisā žūšanas vai apdedzināšanas procesā u. tml.). Etnoarheoloǵiskie novērojumi liecina, ka podniekam un kopienai kopumā bijis svarīgi izgatavot traukus pēc noteiktām tradīcijām, ṇemot vērā gan tehniskos, gan arī simboliskos aspektus.
\end{abstract}

Atslēgas vārdi: vēlais bronzas laikmets, keramikas trauku izgatavošanas tehnoloğiskie aspekti, liesinātāji māla masā, petrogrāfija, Latvijas teritorija.

\section{IEVADS}

Keramikas trauki ir nozīmīgi seno cilvēku saimnieciskajā dzīvē, tos izmanto, lai uzglabātu un pagatavotu pārtikas u. tml. produktus. Keramikas trauku izgatavošana ir salīdzinoši ilgs un sarežgīits process, kas prasa ne vien zināmas iemaņas to izveidē, bet arī cilvēkresursus (māls un tam 
paredzētie liesinātāji, izṇemot organiku, ir smagi, un tos grūti sagādāt vienam cilvēkam). Šì iemesla dēl ir nepieciešams izgatavot pēc iespējas kvalitatīvāku trauku, kurš spētu pildīt savu funkciju pēc iespējas ilgāk. Mālam ir noteiktas dabiskas īpašības, kas to padara piemērotāku keramikas izgatavošanai (pietiekami plastisks, viegli ieveidojams, izturīgs pret termālo šoku u. tml.). Ja reǵionā piemērots māls trauku darināšanai nav pieejams, podnieks to modificē, piejaucot tam dažādu veidu materiālus (granītiskos iežus, gliemežvāku fragmentus, augu atliekas u. tml.) - liesinātājus, lai pieškirirtu topošajam traukam vēlamās īpašības. Tomēr ne vienmēr liesinātāju piejaukšanai mālam ir praktiski iemesli, etnoarheoloǵiskie pētījumi norāda, ka bieži vien konkrētu materiālu pievienošana ir arī simbolisku apsvērumu dēl (piemēram, Gosselain \& Livingstone Smith 2005, 33-47; Arnold 2017, 15-27, u. c.).

Līdz šim veikti daudzi pētījumi attiecīgajā jomā, aptverot dažāda perioda keramiku. Tā, piemēram, detālu liesinātāju analīzi Latvijas teritorijā sastopamajai neolīta, kā arī dzelzs laikmeta keramikai snieguši arheologi Baiba Dumpe (Dumpe 2014a, 71-83; Dumpe 2014b, 32-48; Dumpe 2013, 95-107) un Valdis Bērziņš (Dumpe et al., 2006, 409-441), savukārt Andrejs Vasks pievērsies vēlā bronzas un agrā dzelzs laikmeta trauku veidmasai (Vasks 1991). Tomēr neviens pētnieks nav detāli analizējis liesinātājus, izmantojot laboratorijas metodes, vēlā bronzas laikmeta materiālam.

Vēlajā bronzas laikmetā notiek dažādas izmaiṇas kopienās - mainās ne tikai sabiedrības sociālekonomiskais modelis (modeli "mednieki-zvejnieki" nomaina modelis "lopkopji-zemkopji"), bet arī apbedīšanas tradīcijas, kā arī keramikas trauku izgatavošanas tendences u. tml. İpaši jāizcel, jauna dzìvesvietu tipa - pilskalnu - parādīšanās. Tādējādi pilskalni atspoguḷo konkrētas pārmaiṇas sabiedrībā, arī dažādās amatniecības nozarēs, tai skaitā podniecībā. Tāpēc vērts aplūkot keramikas izgatavošanas tendences šī dzīvesvietu tipa kontekstā.

Arī liesinātāju varbūtējai simboliskajai nozīmei, velkot paralēles ar etnoarheoloǵiskajiem datiem, nav pievērsta pietiekama uzmanība. Saistot dažādu keramikas analīžu rezultātus kopā ar etnoarheoloǵiskajiem datiem, ir iespējams gūt precīzāku ieskatu par kopienu uzskatu un vērtību sistēmu tendencēm, tai skaitā keramikas trauku izgatavošanas aspektiem.

Pētījuma mērķis ir noskaidrot veidmasai pievienoto liesinātāju tehnologiskos aspektus vēlā bronzas laikmeta pilskalnu keramikas materiālā, to praktisko un iespējamo simbolisko piejaukšanas iemeslu kontekstā.

Šajā pētījumā autore ir izvēlējusies analizēt keramikas kolekcijas, kas iegūtas vēlā bronzas laikmeta pilskalnos. To lokācija pamatā nosedz visu Latvijas teritoriju: Daugavas lejteces reǵionā analīzei izvēlēti Dievukalna, Klaṇgukalna, Ķivutkalna, Vīnakalna; Austrumu dạ̦ā - Brikuḷu, Rušenicas; Rietumu daḷā - Krievu kalna, Padures un Paplakas pilskalna keramikas 
kolekcijas. Tādējādi iespējams noteikt galvenās liesinātāju piejaukšanas tendences un to līdzības un atškirības dažādos reǵionos.

\section{METODOLOG̣IJA}

Lai noteiktu liesinātāju veidus un to piejaukšanas tehnoloğiskos aspektus jeb piejaukumu tradīcijas, šajā pētījumā izmantotas divas izpētes metodes: 1) vizuālo īpašību (makroskopiskā) analīze un 2) keramikas petrogrāfiskā analīze.

Vizuālo īpašîbu (makroskopiskā) analīze ietver dažādu keramikas ārējo pazīmju klasificēšanu, grupēšanu, skaitǐšanu un salīdzināšanu: virsmas apdares, trauku vai to fragmentu formas, lausku biezuma, zvirgzdu u. c. vizuāli identificējamu piemaisījumu izmēru fiksēšanu un to līdzību un atšķirību procentuālu izvertēšanu (Shepard 1985, 332). Šī metode izmantota, lai noteiktu trauku fizisko īpašību (piemēram, sienu biezuma un virsmas apdares veida) attiecību pret liesinātāju izmēriem un daudzumu veidmasā (kuri noteikti ar petrogrāfisko analīzi) un tādējādi iegūtu precīzākus datus par liesinātāju pievienošanas tehniskajiem aspektiem, kas saistīti ar trauku vizuālajām īpašībām.

Makroskopiskajai analīzei izvēlēti tādi keramikas paraugi, kuri sniedz pietiekami daudz informācijas par savu sākotnējo veidolu, - nosakāma profila forma, sānu biezums, virsmas apdare u. tml. No Brikuḷu kolekcijas izanalizēti 225 keramikas paraugi, Vīnakalna - 151, Dievukalna - 136, Krievu kalna - 501, Paplakas - 75, Rušenicas - 79, Padures - 63, Klaṇgukalna - 50, Kivutkalna - $120 .^{1}$

Keramikas petrogrāfiskā analīze ir metode, ar kuras palīdzību izgatavotajā keramikas plānslīpējumā tiek izpētīti māla veidmasā esošie mineralogiskie, mikrostrukturālie u. c. neorganiskie materiāli ar petrogrāfiskā jeb polarizējošās gaismas mikroskopa palīdzību (Shepard 1985, 139). Šajā pētījumā petrogrāfiskā analīze izmantota, lai noteiktu māla variācijas, kas lietotas trauku izgatavošanai, kā arī liesinātāju piejaukšanas tehnoloǵiskos risinājumus - izkārtojumu (vienmērīgs, nevienmērīgs), procentuālo daudzumu, izmēru (mm) un veidu keramikas veidmasā.

Analīzēm tika sagatavoti 102 plānslīpējumi, kuru biezums $30 \mu \mathrm{m}$, pirms tam tos vizuāli analizējot. Paraugi izvēlēti pēc reprezentativitātes principa, kas balstās uz virsmas apdares veidu (švīkātā, gludā, apmestā un tekstilā) procentuālo daudzumu kolekcijās. Katrs paraugs n,emts no izvēlētās keramikas lauskas vidusdaḷas (pārgriezts uz pusēm). ${ }^{2}$ Visiem paraugiem veikta virsmas impregnācija. ${ }^{3}$ Paraugi pulēti manuāli uz stikla virsmas, izmantojot dažādus abrazīvus dimanta pulverus (10-30 $\mu \mathrm{m})$. Keramikas plānslīpējumiem ar polarizētas gaismas mikroskopu dažādos palielinājumos noteikts 
māla masas sastāvs (smilts, smalka smilts, aleirīti) un tā raksturs (raupjš, vidējs, smalks), kā arī tam pievienoto liesinātāju veidi. Veidmasai pievienotajiem liesinātājiem noteikts lielākais un vidējais-lielākais (vidējais aritmētiskais no nākamajiem pieciem lielākajiem graudiṇiem) izmērs un tā daudzums veidmasā.

Petrogrāfiskās analīzes veikusi pētījuma autore Latvijas Universitātes Ģeogrāfijas un Zemes zinātṇu fakultātes iežu izpētes laboratorijā. Savukārt paraugu SKRU1 (no Krievu kalna pilskalna kolekcijas) 2014. gadā izgatavojis un analizējis keramikas pētnieks Ūle Stilborgs (Ole Stilborg) kompānijā SKEA (Stilborg Keramik Analysis) Zviedrijā.

\section{LIESINĀTĀJU PIEVIENOŠANAS TENDENCES PILSKALNU MATERIĀLĀ}

Petrogrāfiski analizējot keramikas plānslīpējumus, tika konstatētas astoņas māla masas variācijas (par kritērijiem izmantojot dabisko piejaukumu raupjumu un to izkārtojumu veidmasā), kuras tika izmantotas trauku izgatavošanai (1. attēls). Kā redzams, trauku izgatavošanai lielākoties lietots māls ar smalkiem, vienmērīgi izkārtotiem dabiskajiem piejaukumiem ar bagātu aleirīta daudzumu masā (1. variācija). Salīdzinoši bieži trauku izgatavošanai izmantots arī māls ar vidēji rupjiem, daḷēji vienmērīgi izkārtotiem dabiskajiem piejaukumiem ar bagātīgu smalkas smilts un smilts daudzumu masā (6. variācija). Redzams, ka atsevišksos pilskalnos lietotas arī tādas māla variācijas, kādas nav sastopamas citās analizētajās dzīvesvietās (2. attēls), piemēram, 4. grupa, kas konstatēta tikai Ķivutkalna, Klan,gukalna un Krievu kalna materiālā, un 7. grupa - Dievukalnā un Ķivutkalnā. Tas, iespējams, saistāms ar māla resursu pieejamību konkrētajos reǵionos. Tomēr šim jautājumam nepieciešama detālāka māla izpēte gan dzīvesvietas reǵionā, gan arī māla priekšmetiem, kas tajos sastopami.

Arheologs A. Vasks, analizējot vēlā bronzas un senākā dzelzs laikmeta keramikas veidmasas sastāvu, ir konstatējis divas veidmasas sastāva grupas: A: māla masa + sasmalcināti granītiskie ieži; B: māla masa + granītiskie ieži + organika (Vasks 1991, 19-20), tomēr pētījuma rezultātā konstatēta vēl viena "recepte" - C: māla masa + šamots + granītiskie ieži.

Granītiskie ieži (3.1. attēls) kā liesinātājs ir pats izplatītākais visu analizēto pieminekḷu keramikas kolekcijās. Tas ir arī viens no izplatītākajiem iežiem Latvijas teritorijā. Arī pavardi tika gatavoti no šādiem granītiskiem akmen,iem, tāpēc šis materiāls seno iedzīvotāju kopienām bija labi zināms. Šāds liesinātājs konstatēts visās astoṇās māla masas variācijās. Pēc vizuālajiem novērojumiem, veidmasai pievienotie sasmalcinātie granītiskie ieži ${ }^{4}$ iedalāmi četrās izmēru grupās: 1) smalki (1-2 mm); 2) vidēji (2-4 mm); 


\begin{tabular}{|l|c|}
\hline $\begin{array}{l}\text { Māls ar smalkiem, vienmērīgi izkārtotiem dabiskajiem piejauku- } \\
\text { miem, bagātīgs aleirîta piejaukums }\end{array}$ & 36 \\
$\begin{array}{l}\text { Māls ar smalkiem, dạ̄jēi vienmērīgiem izkārtotiem dabiskajiem } \\
\text { piejaukumiem, bagātīgs aleirīta piejaukums, sastopama smalka } \\
\text { smilts }\end{array}$ & 8 \\
$\begin{array}{l}\text { Māls ar smalkiem, nevienmērīgi izkārtotiem piejaukumiem, } \\
\text { bagātīgs aleirīta un smalkas smilts daudzums }\end{array}$ & 11 \\
$\begin{array}{l}\text { Māls ar vidēji rupjiem, izkārtotiem piejaukumiem, bagātīgs } \\
\text { aleīītu un smalkas smilts daudzums }\end{array}$ & 13 \\
$\begin{array}{l}\text { Māls ar vidēji rupjiem, dạ̄ēji vienmērīgi izkārtotiem } \\
\text { piejaukumiem, bagātīgs smalkas smilts un smilts daudzums }\end{array}$ & 4 \\
$\begin{array}{l}\text { Māls ar vidēji rupjiem, nevienmērīgi izkārtotiem piejaukumiem, } \\
\text { bagātīgs smalkas smilts un smilts daudzums }\end{array}$ & 14 \\
$\begin{array}{l}\text { Māls ar rupjiem, dạ̄ēji vienmērīgi izkārtotiem piejaukumiem, } \\
\text { bagātīgs smilts daudzums }\end{array}$ & 5 \\
$\begin{array}{l}\text { Māls ar rupjiem, nevienmērīgi izkārtotiem piejaukumiem, } \\
\text { bagātīgs smilts daudzums }\end{array}$ & 9 \\
\hline
\end{tabular}
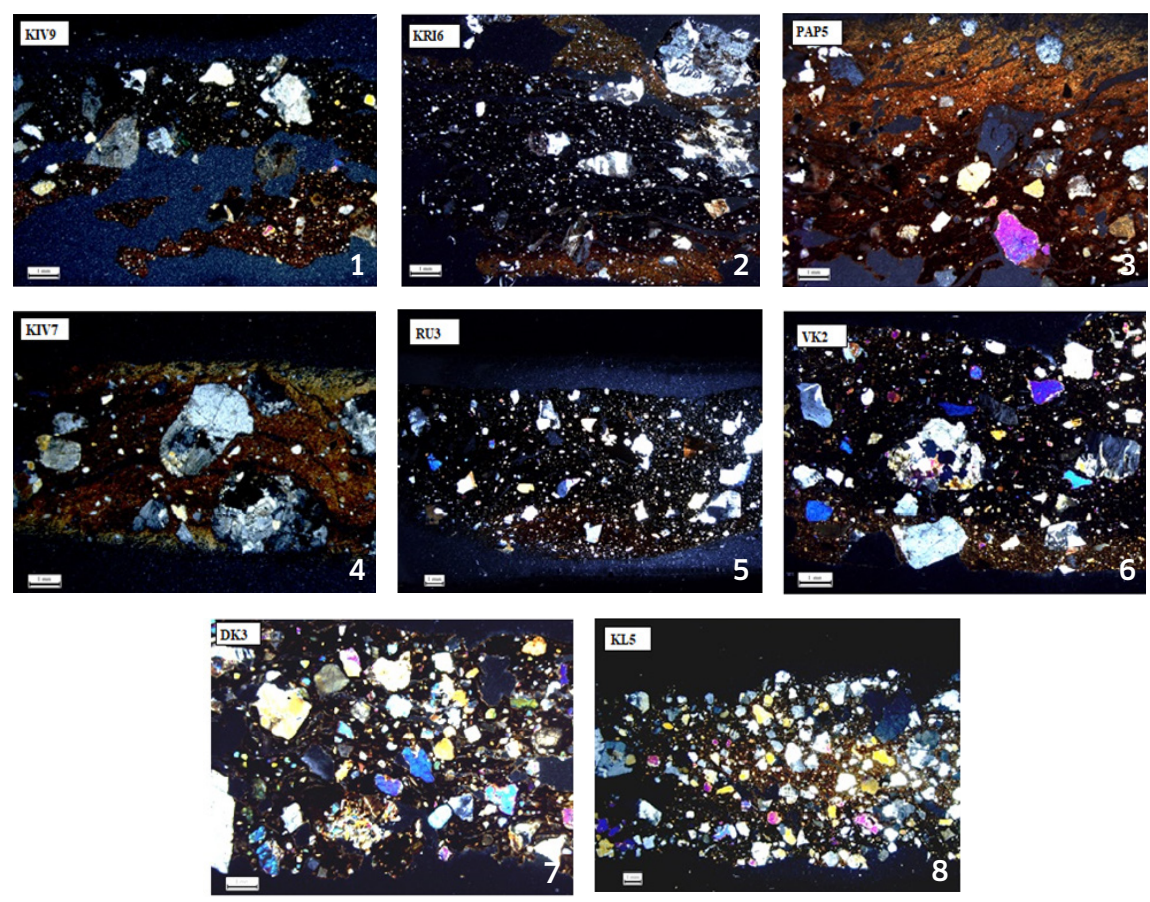

1. attēls. Analizētajās keramikas kolekcijās sastopamās māla masas variācijas.

V. Visockas mikroskopfoto, krustoti polarizatori. 


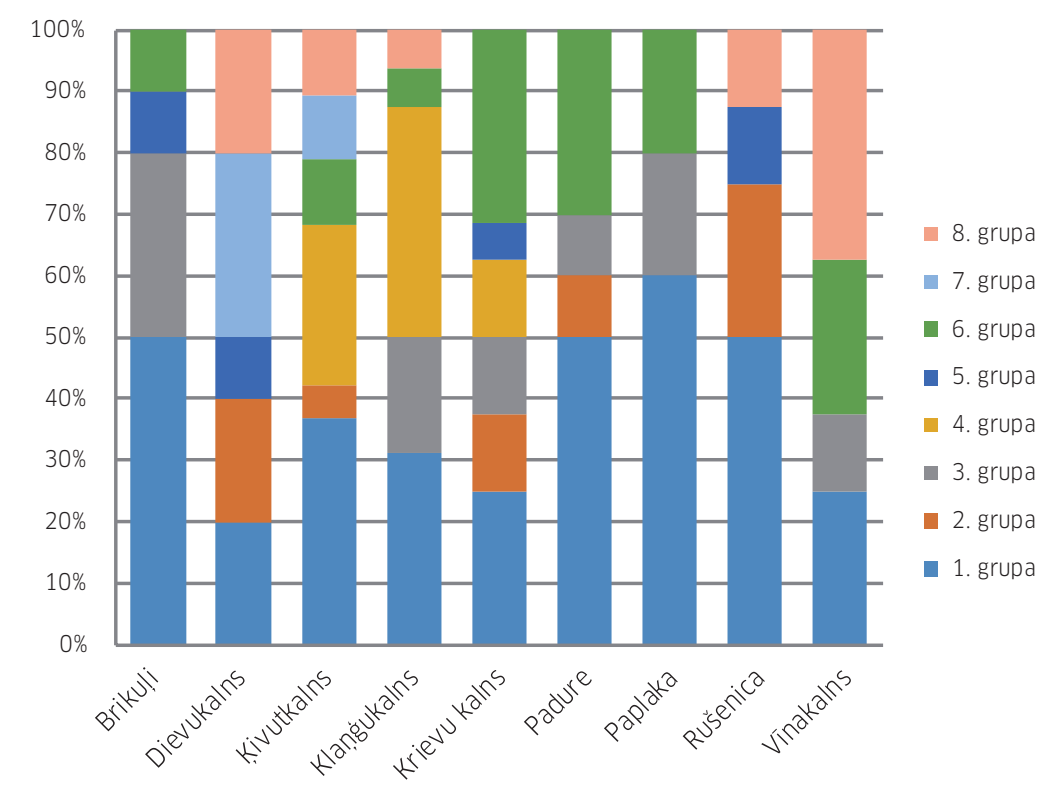

2. attēls. Māla variāciju procentuālais daudzums analizētajās keramikas kolekcijās.

3) rupji (4-6 mm) un 4) l̦oti rupji (6-10 mm). Pētìtajās kolekcijās visbiežāk māla masai pievienots vidēja izmēra sasmalcināts granīts (57\% gadījumu no visām analizētajām). Salīdzinoši bieži (27\%) veidmasai pievienoti rupji liesinātāji. Īpaši jāatzīmē Dievukalna, Rušenicas un Vīnakalna kolekcijas, kurās rupji piejaukumi dominē.

Mazākā mērā māla masai tiek pievienots smalks (12\%) granīts. Šajā gadījumā jāizcel Paplakas pilskalns, kura keramikas kolekcijā 41\% gadījumu veidmasai pievienota šāda variācija. Iespējams, ka Paplakas iedzīvotājiem šāda liesinātāju pievienošanas tendence bijusi pien,emamāka. Jāatzīmē, ka nedz salīdzinoši netālu esošajā Krievu kalnā, nedz Padures pilskalnā šāda tendence nav novērojama. Tādējādi šāda variācija Paplakas pilskalnā varētu būt atzīmējama kā individuāla tendence, kas neiekḷaujas kopējā reǵiona kontekstā.

Retāk māla masai pievienoti l,oti rupji granīta graudiņi - 4\% gadījumu no kopskaita. Triju pieminekḷu keramikas kolekcijās - Ķivutkalnā, Padurē un Paplakā - l̦oti rupji liesinātāji konstatēti netika.

Aplūkojot petrogrāfiski analizēto paraugu liesinātāja izmēra un piejaukuma daudzuma veidmasā attiecību (4. attēls), jāsecina, ka liesinātāja izmērs nav noteicošais faktors tam, cik daudz tas piejaukts māla masai. Praktiski visās kolekcijās gan vidējiem (2-4 mm), gan rupjiem (4-6 mm) liesinātājiem novērojama vienāda piejaukumu tehnoloǵiskā tendence, 
1.
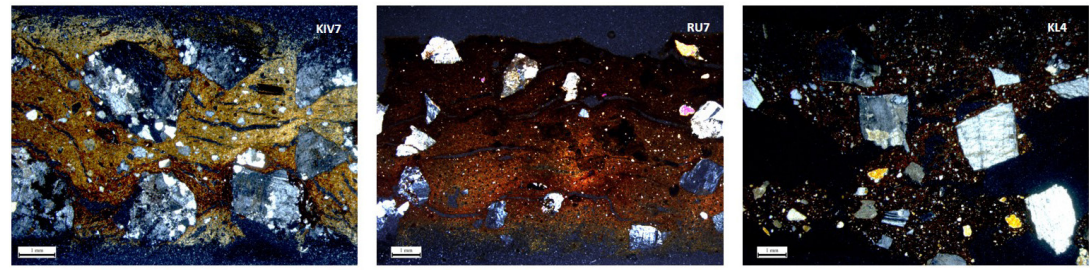

2.
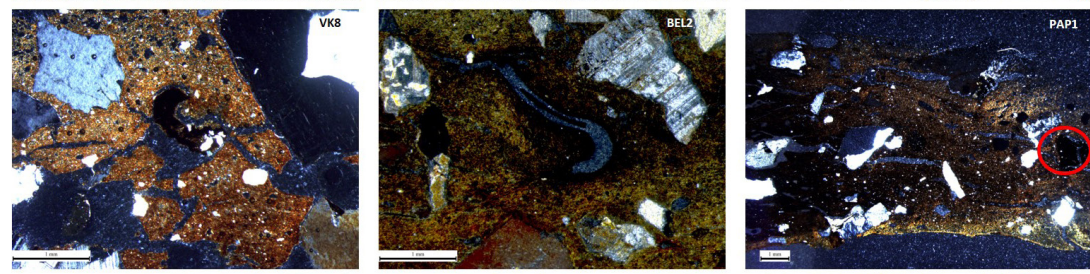

3.
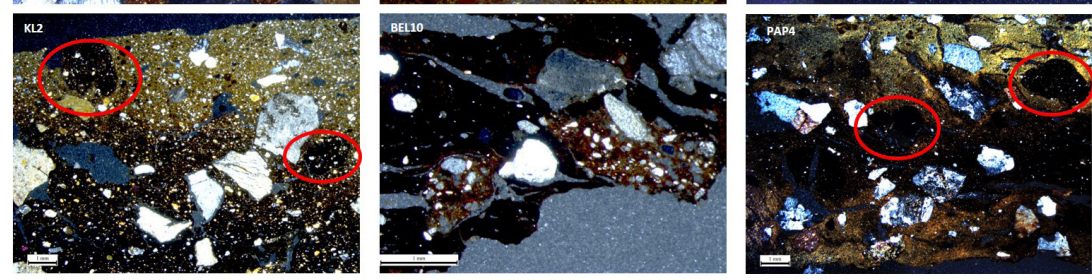

3. attēls. Liesinātāju veidi. 1. - granītiskie ieži; 2. - organika; 3. - šamots.

V. Visockas mikroskopfoto, krustoti polarizatori.

respektīvi, no 4\% līdz pat 37\% veidmasā. Kā iznēēmums jāmin divas kolekcijas Klaṇğukalnā, kur gan vidēji rupji, gan rupji liesinātāji nav veidmasā piejaukti mazāk par 10\%, savukārt Paplakā rupjš liesinātājs petrogrāfiski analizētajos paraugos konstatēts netika. Pēdējam šāds rezultāts ir likumsakarīgs, jo lielākoties keramikai pievienoti smalki granītisko iežu graudiṇi.

Kopumā neesošā kolerācija starp liesinātāja izmēru un tā daudzumu veidmasā norāda, ka podniekam bijuši citi, iespējams, ar trauka funkciju vai proporcijām saistīti kritēriji to pievienošanas daudzumam māla masai.

Aplūkojot sienu biezuma un vidējā-lielākā ${ }^{5}$ liesinātāja izmēru attiecību (5. A attēls), novērojama korelācija. Respektīvi, vairumā gadījumu lielāka izmēra granīta graudiṇi pievienoti tādam traukam, kuram izgatavotas biezākas sienas. Savukārt, aplūkojot sienu biezuma un liesinātāja daudzumu veidmasā attiecību (5. B attēls), novērojama tikai dal̦ēja kolerācija. Šie dati norāda, ka lielākoties pievienoto granīta graudiṇu izmērs un daudzums veidmasai ir atkarīgs no trauka sienu biezuma, kas saistāms ar trauka funkciju.

Organika (3.2. attēls) ietver gliemežvākus, kaulus, mikrofosilijas, kā arī augu atliekas. Tomēr šajā pētījumā autore ar terminu "organika" apzīmē augu atliekas, jo citi šîs grupas materiāli keramikas veidmasā konstatēti netika. Augu atliekas sastāv no celulozes, kas zemās apdedzināšanas 

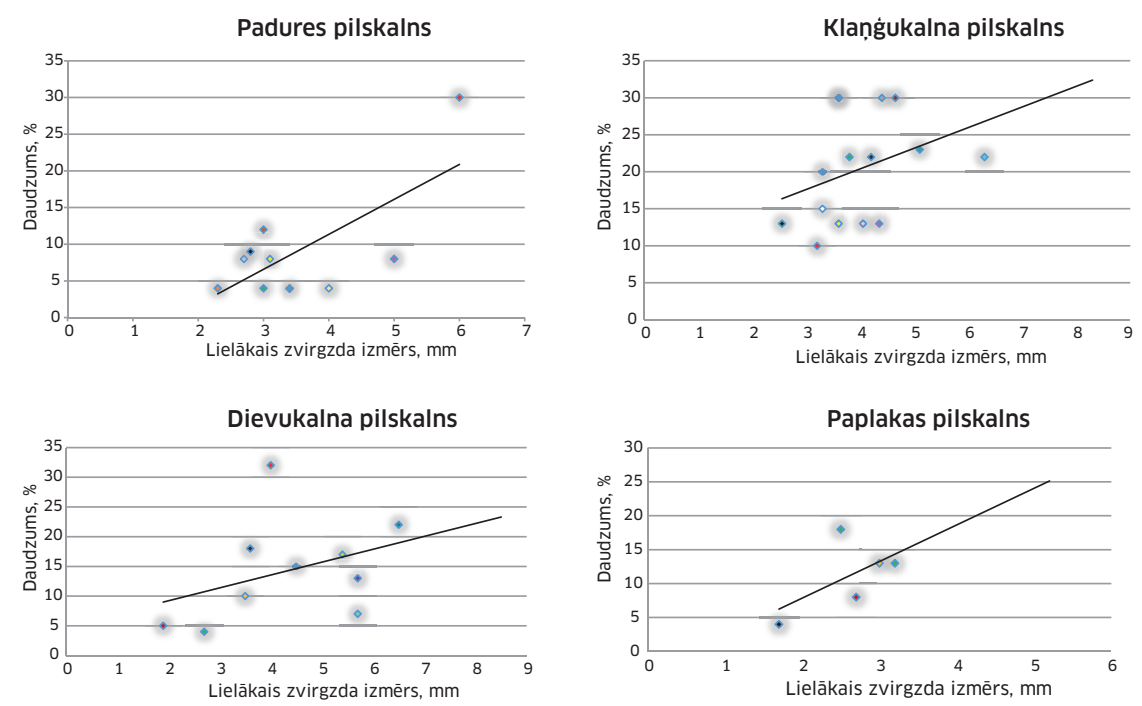

Brikulu pilskalns
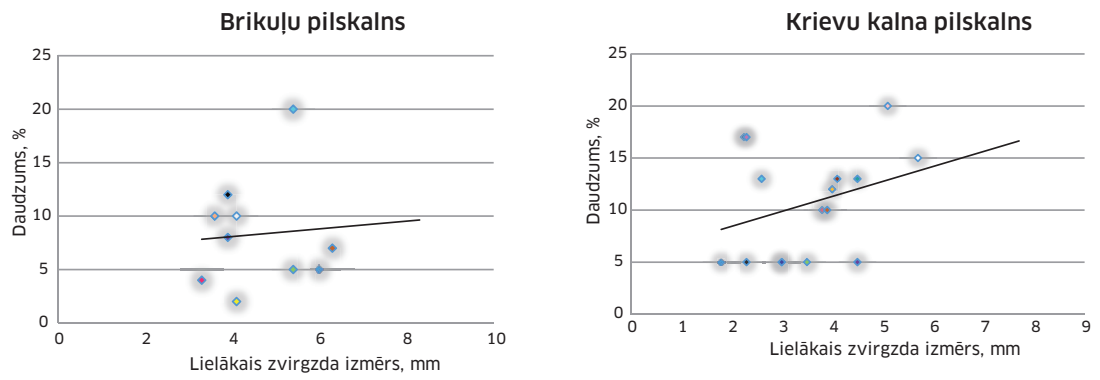

Ķivutkalna pilskalns
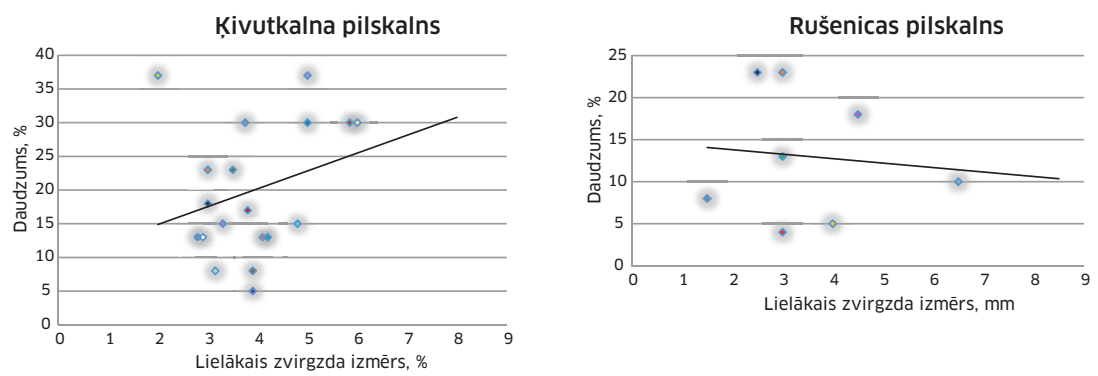

\section{Vīnakalna pilskalns}

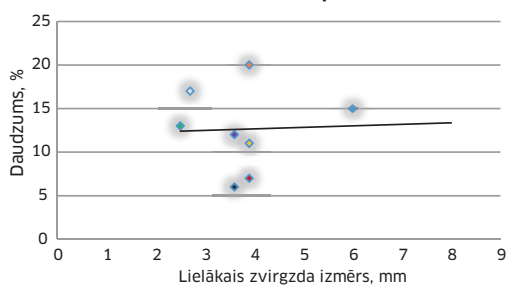

4. attēls. Lielākā granīta zvirgzda izmēra un daudzuma veidmasā attiecība analizētajās kolekcijās. 

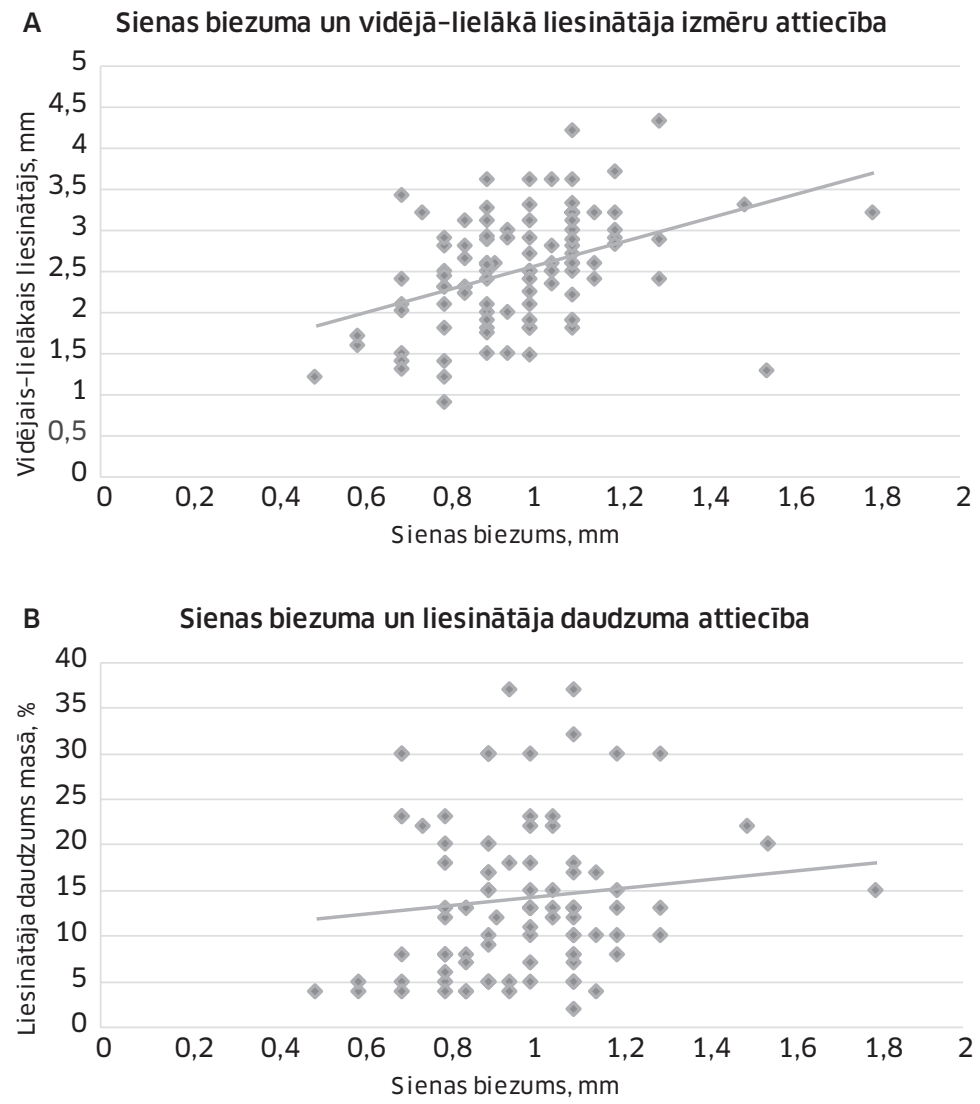

5. attēls. A - sienas biezuma un vidējā-lielākā liesinātāja attiecība veidmasā; B - sienas biezuma un liesinātāja pievienošanas daudzuma masā attiecība.

temperatūrās sadeg (Quinn 2013, 53). Reizēm augu atliekas pilnībā neizdeg zemās temperatūras vai reducējošās apdedzināšanas ietekmē (Quinn 2013, 53). Rezultātā traukā novērojami melnas karbonizētas atliekas caurumiņos jeb porās, kas reizēm ir tādā pašā formā, kādā bijusi organika, pirms tā izdegusi.

Neizmantojot mikroskopiskās metodes, augu atlieku identificēšana sagādā zināmas grūtības, tāpēc arī šajā gadījumā izmantoti petrogrāfiskie dati. Pirms pievēršanās šo datu analīzei jābilst, ka, vizuāli analizējot Krievu kalna keramikas kolekciju, pāris paraugiem tomēr bija iespējams konstatēt smalku stiebriṇu nospiedumus māla masā. Tas liecina, ka šie augu stiebriņi bijuši veidmasā un apdedzināšanas procesā izdeguši, atstājot vien poras un nospiedumus.

No visiem petrogrāfiski analizētajiem paraugiem organika veidmasā tika konstatēta $32 \%$ gadījumu. Paraugi ar organiku veidmasā konstatēti visos 
analizētajos pieminekḷıs. Papildus organikas piejaukumiem visu analizēto paraugu veidmasā sastopami arī granītisko iežu vai šamota liesinātāji. Tikai retos gadijjumos paraugos konstatēts vairāk par vienu augu atlieku (VK1, BR1, KL5).

Šãds rezultāts pētījuma autorē rada šaubas, vai lielākajā daḷā paraugu tas vispār apzināti izmantots par liesinātāju. Iespējams, ka organika lielākoties paraugos nonākusi nejauši vai jau atradusies mālā. Šajā gadījumā Patriks Sīns Kvinns (Patrick Sean Quinn) skaidro: lai gan dažādas augu atliekas (saknes, lapas u. tml.) sekundārajā mālā ${ }^{6}$ jau dabiski atradušās, tomēr podnieks tās parasti izlasa no materiāla pirms veidmasas sagatavošanas (Quinn 2013, 161).

Šamots (3.3. attēls) jeb grogs apzīmē sasmalcinātu jeb saberztu keramikas trauku fragmentus, kas pievienoti māla masai. Šamots ir viens no tiem liesinātājiem, kuru grūti konstatēt, neizmantojot mikroskopiskās analīzes. Šāds liesinātājs bieži vien ir piejaukts līdzīgam mālam, no kāda tas iepriekš taisīts, tāpēc arī, petrogrāfiski analizējot plānslīpējumus, to ir grūti identificēt veidmasā.

No visiem analizētajiem planslīpējumu paraugiem šamots veidmasā konstatēts $11 \%$ paraugu no kopskaita. Divu pilskalnu keramikas kolekcijās - Dievukalnā un Vīnakalnā - šamota liesinātājs veidmasā netika konstatēts. Šādam rezultātam ir trīs iespējamie izskaidrojumi:

1) tā kā maz ticams, ka šo divu dzīvesvietu kopienas nebija izveidojušas savstarpējus kontaktus ar citām Daugavas lejtecē esošajām, varētu spriest, ka dievukalnieši un vīnakalnieši zinājuši par šamota kā liesinātāja izmantošanu veidmasā, tomēr ievērojuši savas tradīcijas;

2) šamotu, kā jau minēts, kopumā grūti identificēt, arī izmantojot mikroskopiskās metodes. Tāpēc iespējams, ka šajos paraugos bijis šĩ veida liesinātājs, taču pētījuma autore nav spējusi to identificēt;

3) pētỉjuma autore nav izvēelējusies petrogrāfiskajām analīzēm tādus šo divu pieminekḷ paraugus, kuros būtu konstatējams šamots. Lìdz ar to iespējams, ka arī šajos pieminekḷos ir trauki, kuru veidmasai pievienots šamots.

Visos konstatētajos gadījumos bez šamota liesinātāja māla masā konstatēts arī granīts. Interesanti, ka pats šamots, kuru bijis iespējams identificēt, veidmasā sastopams pavisam nelielā skaitā. Līdzīga situācija novērojama Skandināvijā, kur arheologs Tomass Ēriksons (Thomas Eriksson), izmantojot gan vizuālās, gan laboratoriskās metodes, konstatējis, ka veidmasā šamots sastopams salīdzinoši nelielā skaitā un tas piejaukts kopā ar granītu vai kādu citu liesinātāju (Eriksson 2013, 336). Tomēr arī šajā gadījumā pastāv iespēja, ka šamota liesinātāju nevarēja identificēt.

Konstatēts, ka vairumā gadījumu šamots pievienots kā liesinātājs mālam ar smalkiem dabiskajiem piejaukumiem (1.-3. variācija). Savukārt 
Ķivutkalna un Krievu kalna paraugiem šamots veidmasai pievienots māla masai ar vidēji rupjiem un rupjiem dabiskajiem piejaukumiem (4., 6. un 8. variācija).

Keramikas trauku veidmasā konstatēti arī dzelzs savienojumi, precīzāk, dzelzs hidroksīdu grupas, iespējams, limonīta minerāli jeb brūnā dzelzsrūda. Šāds piejaukums no visiem analizētajiem pieminekḷiem konstatēts vien Krievu kalna materiālā. Keramikas lauskas ar dzelzs savienojumiem masā veido 12\% no kolekcijas kopskaita (Visocka 2016, 30). Dzelzs savienojumi pārsvarā konstatēti tādām lauskām, kuru virsma ir švīkāta. Tomēr jāatzīmē, ka tā ir dominējošā virsmas apdare dzīvesvietā, tāpēc šāds rezultāts ir logisks.

Dzelzs savienojumi keramikas veidmasā visbiežāk ir ovāli, nelīdzeni veidojumi. To cietības pakāpe ir dažāda un atkarīga no krāsas - gaiši rūsgani ir trausli un drūpoši, savukārt sarkanīgi un tumši brūni dzelzs savienojumi ir cieti (Visocka 2018, 44). Dal̦ai trauku lausku ir sastopami rūsgani plankumi, kas arī ir pieskaitāmi pie dzelzs savienojumiem. Dzelzs savienojumu koncentrācija veidmasā ir dažāda - vienā lauskā sastopami pāris izklaidus orientēti atsevišķi lieli fragmenti, citā - vairāki sīki koncentrēti gabalini.

Diemžēl šobrīd nav iespējams apgalvot, ka dzelzs savienojumi būtu speciāli pievienoti māla masai kā liesinātājs. Šajā gadījumā nepieciešami papildu pētījumi (piemēram, papildu petrogrāfiskās analīzes atsevišķiem paraugiem, kā arī rentgenstaru fluorescences analīzes, lai noteiktu k,īmisko sastāvu). Šobrīd diemžēl šādi pētījumi nav veikti.

\section{LIESINĀTĀJU PIEVIENOŠANAS ASPEKTI}

Liesinātāju pievienošana māla masai reizēm ir grūti izskaidrojama, vienā gadījumā tie piejaukti veidmasai praktisku apsvērumu dēḷ, piemēram, lai pieškirtu mālam vai traukam vēlamās īpašības, kas nodrošina tā funkcijas izpildi. Liesinātāju izvēli ietekmē arī tādi apstākḷi kā laika, vietas resursi un cilvēkresursi (Quinn, 2013, 153). Vairumā etnoarheoloǵisko pētījumu novērojams, ka podniekam bijuši arī simboliski apsvērumi liesinātāju pievienošanai veidmasā. Šādus tradicionālos etnisko (no modernās sabiedrības norobežoto) cilšu uzskatus zināmā mērā varētu attiecināt arī uz vēlā bronzas laikmeta kopienām.

Tehnoloǵiskie aspekti. Dažādi liesinātāji piešksir māla masai konkrētas īpašības. Nav pamata uzskatīt, ka podnieks nav zinājis vai ievērojis šādas likumsakarības un izmantojis savā labā. Šajā sakarībā svarīgi raksturot katra konstatētā liesinātāja fizikālās īpašîbas un to, kā tie ietekmē trauka izgatavošanas procesu un gatavā produkta kvalitāti. 
Granītiskie ieži nodrošina trauka siltumizturību, palielinot tā termālo konduktivitāti (spēju vadīt vai uzturēt siltumu), kas ir īpaši svarīga keramikai, kura domāta ēdiena pagatavošanai pavardā (Quinn 2013, 158). Tādi liesinātāji, kuriem ir līdzīga termālā ekspansija (izplatǐšanās apdedzināšanas ietekmē) ar māla masu, piemēram, gliemežvāki un šamots, izplešas un saraujas, neizraisot bojājumus traukā. Savukārt liesinātāji ar augstāku ekspansijas koeficientu nekā mālam sildīšanas un atdzišanas procesos var izraisīt bojājumus keramikas traukā. Šajā gadījumā jāatzīmē kvarca minerāls. Lai gan tam ir lielāks ekspansijas koeficients nekā mālam, savu fizikālo īpašību dēḷ tas palielina trauka izturību gan apdedzināšanas procesā, gan arī pēc tam (Quinn 2013, 159).

Turpretim, pievienojot organiku, traukos veidojas poras, kas zināmā mērā samazina trauka termālo konduktivitāti. Tomēr šīs poras, kas radušās, izdegot organikai, aptur plaisu izveidošanos vai to turpmāku virzību uz priekšu keramikas traukā.

Jebkurā gadījumā ir svarīga trauka izturība pret termālo šoku apdedzināšanas laikā, lai izgatavotais pods neietu bojā. Arī šo īpašību nodrošina liesinātāju pievienošana veidmasai. Kā atzinis Tomass Ēriksons, tad viens no piemērotākajiem liesinātājiem, kas nodrošina izturību pret termālo šoku, ir šamots (Eriksson 2013, 331).

N̦emot vērā visu iepriekš minēto, nevar noliegt, ka fizikālās īpašības tiek stingri n,emtas vērā liesinātāju izvēlē, tomēr arī tas nesniedz skaidru atbildi uz jautājumu, kāpēc izmantots tieši šis liesinātājs. Visuzskatāmākais piemērs ir šamots. Pēc T. Ëriksona atzinuma, kopumā tas ir viens no vispiemērotākajiem liesinātājiem trauka veidmasai, tomēr šamots parauga māla masā sastopams salīdzinoši nelielā daudzumā, kā arī vienmēr pievienots klāt citiem liesinātājiem. Tas vedina domāt, ka šamots pievienots vairāk simbolisku, nevis praktisku apsvērumu dēl (Eriksson 2013, 337). Šo apgalvojumu pastiprina apstāklis, ka dzīvesvietās, iespējams, bijis pieejams liels skaits vairs neizmantojamu - saplīsušu - keramikas trauku vai to atlieku, tāpēc tas bijis viegli iegūstams un izmantojams pārstrādes materiāls, tomēr plaši lietots nav ticis.

Simboliskie aspekti. Tā kā arheoloǵiskais priekšmets ir mēms un rakstītie avoti vēlajā bronzas laikmetā Latvijas teritorijā neeksistē, vienīgais veids, kā spriest par šì laikposma kopienu domāšanu - vērtību sistēmu, tradīcijām, nemateriālo kultūru kopumā un arī dažādiem trauku izgatavošanas principiem, ir etnoarheologiskie dati. ${ }^{7}$ Pirmkārt, pamatojoties uz šādiem datiem, iespējams spriest par iemesliem, kāpēc izmantots konkrētais liesinātājs keramikas trauka izgatavošanā. Otrkārt, var spriest par iemesliem, kāpēc pastāv vai nepastāv atškirīgas veidmasas un liesinātāju tendences pētāmajā reǵionā. 
Olivjē Goseleins (Olivier Gosselain) un Aleksandrs Livingstons Smits (Alexandre Livingstone Smith), pētot Subsahāras Āfrikas cilšu podnieku māla izvēli un apstrādi, noskaidrojuši, ka veidmasas sagatavošanu ietekmē dažādi simboliskie aspekti. Tā, piemēram, Boko podnieki rūpīgi no māla masas izlasa visas augu atliekas, jo tās izmanto, lai izgatavotu zāles pret pietūkumu, kas mēdz piemeklēt keramiķus (Gosselain \& Livingstone Smith 2005, 41).

Savukārt podnieki no dažādām Āfrikas valstīm (Burkinafaso, Senegālas, Nigērijas, Nigēras, Mali u. c.) šamotu pievieno māla masai, jo tādējādi vecie senču trauki tiek savienoti ar jaunajiem, lai tie būtu tikpat izturīgi (Gosselain, Livingstone Smith 2005, 41). Tāpat svarīgs aspekts veidmasas izgatavošanā un dažādu liesinātāju izvēlē ir cieņa pret saviem senčiem un viṇu tradīcijām gan sadzīvē, gan arī podniecībā, un trauku izgatavošana pēc konkrētiem parametriem ir kḷuvusi kā likums kopienai (Gosselain 1999, 209). Šajā gadījumā jāatzīmē, ka daļa Nigēras cilšu ir zinājuši par citiem liesinātāju veidiem, taču tos nav pārn,ēmuši un stingri ievērojuši savas receptes un savas tradīcijas (Gosselain 2008, 163). Taču šis atzinums nav saistīts tikai ar simboliskajiem aspektiem, tam ir arī tehniski iemesli, jo ir tikai log̣iski, ka podnieki izmanto sev zināmus un pārbaudītus pan̄ēmienus trauku izgatavošanā. Savukārt pētnieki Hulio Mersaders (Julio Mercader) un citi konstatējuši, ka Ituri cilšu podniekiem aptuveni 1000 gadu ilgā laikposmā bijušas izteiktas tehnoloǵiskās līdzības starp etniski un sociālekonomiski atšḳirīgām grupām (Mercader et al. 2000, 181). Respektīvi, Ituri podnieki neatkarīgi no etniskās un sociālekonomiskās piederības izgatavojuši traukus vienā veidā. Tādējādi pētnieki secinājuši, ka šīm ciltīm bijuši cieši kontakti, kas atspogul,ojušies vienotos keramikas trauku izgatavošanas tehnologiskajos aspektos (Mercader et al. 2000, 181).

No iepriekš minētā jāatzìmē, ka arī Latvijas teritorijas vēlā bronzas laikmeta materiālā novērojamas izteiktas līdzības keramikas trauku izgatavošanas tehnoloǵiskajos aspektos, īpaši liesinātāju veidu un pievienošanas tendencēs. Arī izvēlētais māla izejmateriāls, izṇemot atsevišḳus gadījumus, ir salīdzinoši viendabīgs. Tomēr nevarētu piel̦aut, ka izteikti līdzīgas izgatavošanas tehnikas un liesinātāju piejaukšanas aspekti saistāmi ar ciešiem kontaktiem starp analizētajām dzīvesvietām, kā arī ar kopīgu vērtību sistēmu. Pētamajā teritorijā, kur atradušās analizētās dzīvesvietas, ir līdzīgu resursu pieejamība, tāpēc arī trauku izgatavošanas tendences bijušas stipri līdzīgas. 


\section{DISKUSIJA}

Pētnieku viedokḷi par liesinātāju simbolisko lomu un nozīmi keramikas trauku izgatavošanā ir atšksirīgi. Tā, piemēram, Patriks Sīns Kvinns uzskata, ka trauku izgatavošanas tradīcijas atspoguḷo sabiedrības sociālo apziṇu, tāpēc podnieka liesinātāja izvēli (un arī trauka izgatavošanu kopumā) ietekmē arī tādi faktori kā cilvēku kopas uzskati, tradīcijas, identitāte un tajā pastāvošie tabu (Quinn, 2013, 153). Tādējādi veidmasas receptes maiņa saistāma ar sabiedrības domāšanas, vērtību sistēmas, estētisko priekšstatu, sociālekonomisko procesu u. tml. maiņu. Piemēram, sabiedrības sociālekonomiskā modeḷa maiṇa (piemēram, modeli "mednieki-zvejnieki" nomaina modelis "lopkopji-zemkopji") ietekmē arī keramikas trauku izgatavošanas aspektus. Šādu situāciju daḷēji varētu attiecināt arī uz Latvijas teritoriju, kur neolīta (tajā pastāv modelis "mednieki-zvejnieki") trauku veidmasā par liesinātāju izmantota organika (gliemežvāki, zivju kauli, augu atliekas u. tml.), savukārt jau agrajā bronzas laikmetā, kad notiek pāreja uz zemkopību un lopkopību, māla masai sāk piejaukt granītiskos iežus, arī keramikas vizuālais izskats paliek stipri vienkāršāks (bagātīgo ornamentu uz trauka virsmas nomaina švīkāta, gluda, retāk apmesta un tekstila virsma) (Vasks 2015, 44, 106).

Šādam viedoklim nepiekrīt antropologs Dīns Arnolds (Dean Arnold), kurš uzskata, ka māla veidmasa nav sabiedrības spogulis (Arnold 2017, 20). Pētnieks uzskata, ka veidmasas sastāva maiņa primāri atkarīga no citiem faktoriem, piemēram, ja beidzas māla resurss un tā vietā tiek izmantots cits ar atšķirīgu kvalitāti, podnieks adaptējas un lieto citus liesinātājus, lai iegūtu vēlamo masu (Arnold 2017, 19). Tāpat viņš atzīmē, ka visiem podu veidiem nav vienas universālas veidmasas receptes, tā atkarīga no trauka funkcijas, un tāpēc liesinātāja loma kā sabiedrības normu atspoguḷotājam ir sekundāra.

Pētījuma autore uzskata, ka abi - tehnoloǵiskie un simboliskie - faktori ir vienlīdz nozīmīgi keramikas trauku izgatavošanas procesā. Tā, piemēram, iepriekš aplūkotā granīta graudu izmēra, daudzuma veidmasā un sienu biezuma attiecība Latvijas teritorijas materiālā norāda, ka piejaukšanas tendences atkarīgas no trauku biezuma, kas, savukārt, ir atkarīgas no trauka funkcijas. Turpretim etnoarheologiskie novērojumi liecina, ka tieši simboliskie aspekti ir viens no galvenajiem iemesliem, kāpēc lietota un izgatavota tieši tāda veidmasas recepte. Tāpat autore uzskata, ka arī kopienu sociālekonomiskie faktori ietekmē keramikas trauku izgatavošanas tendences. Uzskatāms piemērs, kā jau minēts, Latvijas teritorijā ir pārejas posms no mednieku-zvejnieku modeḷa uz lopkopju-zemkopju modeli, kas ietekmē ne vien keramikas trauku vizuālo izskatu, bet arī liesinātāju piejaukšanas tendences. 


\section{SECINĀJUMI}

Analizētajā materiālā konstatētas astoṇas māla masas variācijas (no smalkiem līdz rupjiem dabiskajiem piejaukumiem). Podnieki keramikas izgatavošanai lielākoties izmantojuši mālu ar smalkiem dabiskajiem piejaukumiem (1. variācija).

Pilskalnu materiālā kopumā konstatējamas trīs veidmasas receptes: 1) granītiskie ieži; 2) granītiskie ieži un organika; 3) granītiskie ieži un šamots. Granītiskie ieži ir dominējošais liesinātājs visās keramikas kolekcijās, tas pievienots klāt arī citiem materiāliem - organikai un šamotam. Tādējādi analizētajā materiālā netika konstatēti tādi trauki, kuriem par liesinātāju būtu izmantots tikai šamots vai organika.

Divās kermikas kolekcijās - Dievukalnā un Vīnakalnā - šamota liesinātājs konstatēts netika. Šāds rezultāts varētu liecināt par individuālām liesinātāju pievienošanas tendencēm. Tomēr svarīgi atzīmēt, ka šamotu grūti identificēt, arī izmantojot mikroskopiskās metodes, tāpēc iepriekš minētais pieņēmums ir tikai varbūtība.

Organikas piejaukums veidmasā nav homogēns, un reti kad veidmasā tika konstatēts vairāk par vienu augu atlieku. Pētījuma autore uzskata, ka daḷā analizēto paraugu šis materiāls nonācis nejauši vai jau atradies mālā pirms trauka izgatavošanas. Respektīvi, daḷā gadījumu nav izmantots par liesinātāju.

Pētījumā noskaidrots, ka liesinātāju pievienošanas tendencēm svarīga bijusi trauka funkcija, kas daḷēji atspoguḷojas keramikas vizuālajās īpašībās (šajā gadījumā aplūkots trauku sienu biezums). Arī granīta, šamota un organikas pievienošana veidmasai uzlabo trauka fiziskās īpašības, piemēram, apdedzināšanas procesā neveidojas plaisas, tas ilgāk uztur siltumu u. tml.

Savukārt etnoarheolog̣iskie novērojumi norāda, ka veidmasas recepšu viendabīgums reǵionā varētu būt saistāms ar savstarpējiem kontaktiem reǵionā un zināšanu pārnesi. Tāpat ilgstošā veidmasas tradīciju noturība vēlajā bronzas laikmetā savā ziņā norāda uz senču kultu, respektīvi, trauki izgatavoti "tā, kā mani senči to ir darījuši". Sava ietekme uz keramikas trauku izgatavošanas tendencēm, iespējams, ir arī sabiedrības sociālekonomiskā modeḷa maiņai. Latvijas teritorijā konstatēta trauku izgatavošanas tendenču maiņa, jo vēlā neolīta modeli "mednieki-zvejnieki" nomaina agrā un vēlā bronzas laikmeta modelis "lopkopji-zemkopji". Tomēr šīs hipotēzes apstiprināšanai vai apgāšanai nepieciešami papildu pētījumi.

No visa iepriekš minētā var secināt, ka liesinātāju pievienošanas tendencēm un dažādu veidmasas recepšu izgatavošanai, pēc autores domām, gan tehniskie, gan simboliskie aspekti bijuši vienlīdz nozīmīgi. 


\section{SAIISINĀJUMI}

BR - Brikuli; BEL - Padure; DK - Dievukalns; KIV - Ķivutkalns; KRI, SKRU - Krievu kalns; KL - Klaņğukalns; PAP - Paplaka; RU - Rušenica; VK - Vīnakalns. Keramikas plānslīpējumu paraugu šifri.

\section{IZMANTOTIE AVOTI UN LITERATŪRA}

\section{AVOTI}

Brikuḷu pilskalna keramikas kolekcija. LNVM. Arheologijas departaments, inv. Nr. A 12468; A 12405; A 12379.

Dievukalna pilskalna keramikas kolekcija. LNVM. Arheologijas departaments, inv. Nr. - kolekcija nav pien,emta;

Klaņǵukalna pilskalna keramikas kolekcija. LNVM. Arheologiijas departaments, inv. Nr. A 9960.

Krievu kalna keramikas kolekcija. LNVM. Arheologijas departaments, inv. Nr. A 13957; A 139578; A 11160; SA 9069; SA 1969.

Ķivutkalna pilskalna keramikas kolekcija. LNVM. Arheoloğijas departaments, inv. Nr. VI 120.

Padures pilskalna keramikas kolekcija. LNVM. Arheologijas departaments, inv. Nr. A 13517; A 13673; A 13291; A 13372.

Paplakas pilskalna keramikas kolekcija. LNVM. Arheologijas departaments, inv. Nr. A 12438.

Rušenicas pilskalna keramikas kolekcija. LNVM. Arheoloğijas departaments, inv. Nr. A 13225; A 13811; A 13810; A 13672; A 13515; A 13683; A 13413; A 13289.

Vīnakalna pilskalna keramikas kolekcija. LNVM. Arheolog̣ijas departaments, inv. Nr. - kolekcija nav pienemta.

\section{LITERATŪRA}

Arnold, E. D., 2017. Raw Material Selection, Landscape, Engagements, and Paste Recipes: Insights from Ethnoarchaeology. In Matiéres á Penser: Raw materials aquisition and processing in Early Neolithic pottery productions. Proceedings of the Workshop of Namur (Belgium), 29 and 30 May 2015. Société Préhistorique Francaise, Paris, 15-27.

Dumpe, B., 2013. Spodrinātā un gludinātā keramika Asotes pilskalna keramikas kolekcijā. LNVM Zinātniskie lasijumi 2007.-2010., 95-107.

Dumpe, B., 2014a. Bezripas keramika Tērvetes senvietās. LNVM Zinātniskie lasījumi 2011.-2013., 23-32.

Dumpe, B., 2014b. Podnecība Kentes pilskalnā - pa Adolfa Stubava pētījumu pēdām. Arheologija un etnogrāfija, 28, 32-48.

Dumpe, B., Bērziňš, V. \& Stilborg, O., 2006. A dialogue across the Baltic on Narva and Ertebølle pottery. Papers of the seminar "Early Pottery in the Baltic - Dating, Origin and Social Context", Schleswig, 20th-21st October 2006. Berichte der RömischGermanische Kommission 89, 409-441.

Eriksson, T., 2013. Grog tempering during Scandinavian Bronze Age. Naturwissenschaftliche Analysen vor- und frügeschichtlicher Keramik III.: Anwendungsbereiche, Auswertungsmöglichkeiten. GMBH, 331-351. 
Gosselain, O. \& Livingstone Smith, A., 2005. The Source Clay Selection and Processing Practices in Sub-Saharan Africa. Livingstone Smith, A., Bosquet, D. \& Martineau, R., eds. Pottery Manufacturing Processes: Reconstruction and Interpretation. British Archaeological Reports, 33-47.

Gosselain, O., 1999. In Pots we Trust: The Processing of Clay and Symbols In SubSaharan Africa. Journal of Material Culture, 4 (2), 205-230.

Gosselain, O., 2008. Mother Bella Was Not a Bella. Inherited and Transformed Traditions in Southwestern Niger. Stark, M. T., Bowser, B. J. \& Horne, L., eds. Cultural Transmission and Material Culture. Breaking Down Boundaries. The University of Arizona Press, 150-177.

Mercader, J., Garcia-Heras, M. \& Gonzalez-Alvazer, I., 2000. Ceramic Tradition in the African Forest: Characterization Analysis of Ancient and Modern Pottery from Ituri, D. R. Congo. Journal of Archaeological Science, 27, 163-182.

Quinn, P. S., 2013. Ceramic Petrography: The Interpretation of Archaeological Pottery \& Related Artefacts in Thin Section. Archeopress.

Shepard, A. O., 1985. Ceramics for the archaeologist. Carnegie Institution of Washington.

Vasks, A., 1991. Keramika epokhi pozdnei bronzi i rannego zheleza Latvii. Zinātne.

Vasks, A., 2015. No medniekiem un zvejniekiem lidz lopkopjiem un zemkopjiem: Latvijas aizvēstures senākais posms (10500. - 1. g. pr. Kr.). Zinātne.

Visocka, V., 2016. Vēlā bronzas laikmeta keramika Skrundas Krievu kalna un Paplakas pilskalnos: reğionālās līdzības un atškirības. Jauno vēsturnieku zinātniskie lasijjumi I, 2015. Valmieras muzejs, LU LVI, 26-34.

Visocka, V., 2018. Iron Compounds in the Pottery: Temper or Coincidence? A Case Study of Krievu kalns Hillfort. II International Symposium: Clays and Ceramics. Book of Abstracts, 29-31 January. Riga, 44-45.

\section{ATSAUCES UN PIEZĪMES}

${ }^{1}$ Kivutkalna keramikas kolekcija sava lielā apjoma dēl (apmēram 38 tūkst. lausku) šajā pētījumā tikai dal̦ēji izanalizēta. Tomēr arī no šiem analizētajiem paraugiem ir iespējams gūt priekšstatu par galvenajām tendencēm piemineklī.

${ }^{2}$ Paraugs pārgriezts uz pusēm vertikālā attiecībā pret trauka mutes daḷu.

${ }^{3}$ Ar speciālu līmi noklāta lauskas nogrieztā daḷa.

${ }^{4}$ Šajā pētījumā autore granītiskos iežus saīsinot apzīmē arī ar vārdu "granīts" vai "zvirgzds".

${ }^{5}$ Attiecības noteikšanai izmantots vidējais-lielākais liesinātāja izmērs, jo tas viskorektāk atspogul,o parauga veidmasas tendences.

${ }^{6}$ Latvijas teritorijā sastopami vienīgi sekundārie māli - tādi, kas dabas procesu (ūdens, ledāju u. tml.) ietekmē sanesti un sagulsnējuši. Šì tipa māli ir vairāku sajaukušos mālu kopums ar dažādiem dabiskajiem piejaukumiem, piemēram, aleirīta, smilts, dažādu karbonātu u. tml. (Sīkāk par māliem skat. Worall, W. E., 1986. Clays and Ceramic: Raw materials. Springer.)

${ }^{7}$ Etnoarheoloǵija ir ar antropoloǵiju un arheoloǵiju saistīta nozare, kas pēta mūsdienu etniskās tradicionālās kultūras, kuras stingri ievēro savas tradīcijas un pilnīgi vai dalēeji ir norobežojušās no modernās sabiedrības. Iegūtie dati tiek izmantoti, lai izveidotu analoǵijas un modeḷus, kurus būtu iespējams attiecināt uz aizvēsturiskajām kultūrām (Ethnoarchaeology. Pieejams: http://dictionary. reference.com/browse/ethnoarchaeology (skatits 08.12.2017.) 


\title{
TEMPER IN CLAY MATRIX DURING THE LATE BRONZE AGE: TECHNICAL AND SYMBOLICAL ASPECTS
}

\section{VANDA VISOCKA}

Mg. hist., Ph.D. student, research assistant in archaeology, Faculty of History and

Philosophy, the University of Latvia

Email: vanda.visocka@lu.lu

\begin{abstract}
The paper aims at analysing the technological aspects of pottery tempering variations in hillforts during the Late Bronze Age, as well as giving an insight into the technical and symbolical reasons behind adding different materials to clay to modify it. Tempering materials were analysed by their macroscopic (simple measurements) and microscopic (petrographic analysis) features to determine the overall tendencies in the analysed hillforts. For this reason, altogether 102 thin sections were made. The study revealed similar tempering tendencies in all the analysed pottery assemblages. The dominant tempering material is granitic rock, while some samples contain grog and plant material. All the tempering materials are useful in pottery production (for example, they prevent vessel from cracking during drying or firing). Some ethno-archaeological data indicate that for potters and the general population it was important to follow fixed pottery traditions.
\end{abstract}

Keywords: Late Bronze Age, aspects of pottery production, temper, petrography, territory of Latvia.

\section{SUMMARY}

Three possible 'recipes' of clay matrix were discerned during research: 1) clay with admixture of granitic rock; 2) clay with admixture of granitic rock and organics (plant material); 3) clay with admixture of granitic rock and grog.

The dominating recipe is clay with admixture of granitic rock (Fig. 3.1). Four groups of inclusions can be discerned by the size of the granitic rock particles: 1) fine $(1-2 \mathrm{~mm}) ; 2)$ medium $(2-4 \mathrm{~mm}) ; 3)$ coarse (4-6 mm); 4) very coarse $(6-10 \mathrm{~mm})$. In most cases the dominating size of the particles of tempering material was medium (in 57\% of cases). The occurrence of coarse particles was also frequent (27\%). It must be noted that the latter 
variation of the size of granite particles is dominant in three assemblages: from Dievukalns and Vinakalns hillforts in the lower reaches of the Daugava River and in Rušenica in the eastern part of Latvia. In case of the pottery from Paplaka hillfort the dominant tempering variation is admixture of fine granite particles to clay ( $41 \%$ of all analysed sherds). It indicates that potters, who lived on the mentioned hillforts, had different perceptions of the 'best' quality of the pottery fabric.

However, as the scatter plot shows (Fig. 4), the overall tempering features are similar in all the analysed assemblages. No clear correlation among them can be seen which may indicate that the tempering features depend on different aspects of the vessel. For this reason, the author compared the wall thickness and maximum average size of particles as well as their proportional amount in the clay matrix from four settlements (Brikuli, Dievukalns, Kivutkalns and Krievu kalns; to keep the scatter plots graphic, only four settlements were selected). The scatter plots (Fig. 5) show that in general the amount of tempering material and the size of its particles depend on the thickness of the vessel's walls (for thicker walls higher proportion of tempering material is added and particles are larger than for vessels with thinner walls).

As concerns organics, only plant material was identified in the analysed samples (Fig. 3.2). 32\% of all samples contained plant material. Only in a few cases more than one plant material was found in the clay matrix (VK1, BR1, KL5). Such result raises doubts about the use of the respective material as a tempering variation. Traces of plant material could also be a result of natural impurity, as is often the case with secondary clay (which is the only type of clay found in the territory of Latvia). Further research is necessary to provide a more conclusive answer about the use of the respective material as a tempering substance.

Grog was found in $11 \%$ of all the analysed samples (Fig. 3.3). In two assemblages grog was not present - in those from Dievukalns and Vinakalns. Two explanations are possible: either the communities inhabiting these hillforts did not use the respective material as a tempering substance because of symbolical/traditional considerations, or the author has accidentally selected for the analysis samples that did not contain grog. In all the cases apart from grog, granitic rock tempering has also been added to clay.

Two reasons are possible for adding a tempering substance to clay: 1) technological and 2) symbolical. The technological aspects include the 'idea' that clay must be modified in order to achieve maximum good pottery products. All the materials, which were used as tempering substances (granite and grog) in the analysed assemblages, reduce the risk of cracking during the drying or firing process and improve resistance against thermal shock. The symbolic aspects include the idea of a specific tempering 
tradition or variation serving as an identification mark of the respective community. For example, some ethno-archaeological studies have revealed that potters often made vessels in the same way their ancestors did as a sign of respect for them. The author believes that the idea that pottery must be made in the same manner as the ancestors did could be attributable to the Late Bronze Age communities in the territory of Latvia as well. The author considers both aspects - technological and symbolical - to be of equal importance in pottery production. 


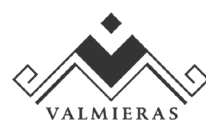

MUZM E S

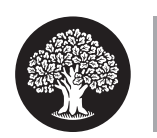

LATVIJAS UNIVERSITĀTE

LATVIJAS VĒSTURES

INSTITŪTS

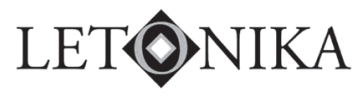

\title{
III ZINĀTNISKĀ KONFERENCE \\ "JAUNO VËSTURNIEKU \\ ZINĀTNISKIE LASĪJUMI"
}

\author{
Valmieras muzejā \\ Valmierā, Bruṇinieku ielā 3 \\ 2017. gada 20. oktobrī
}

\section{PROGRAMMA}

9.30 Dalībnieku reǵistrācija (Valmieras muzeja Izstāžu namā)

10.00 Konferences atklāšana

10.15.-11.00 Ievadreferāti:

Valdis Bērziņš, Dr. habil. hist., LU Latvijas vēstures institūta vadošais pētnieks, Mārcis Kalniņš, Mg. hist., Latvijas Universitātes Vēstures un filozofijas fakultātes doktorants Arheoloğiskā izpēte Riṇnukalna akmens laikmeta apmetnē 2017. gadā

Jānis Šiliņš, Dr. hist., Latvijas Nacionālā arhīva Latvijas Valsts vēstures arhìva vadošais pētnieks, Vidzemes Augstskolas Sociālo, ekonomisko un humanitāro pētijumu institūta pētnieks

Lielais meklējumu gads: Vidzeme 1917. gada politiskajos procesos 


\section{1. sēde}

11.00-13.00 Sēdi vada: prof. Dr. hist. Ilgvars Butulis (LU VFF), prof. Dr. art. Jānis Kudiņš (JVLMA), Dr. hist. Edvīns Evarts (LU LVI)

\section{Liene Ozolina}

Mākslas darbs $k \bar{a}$ vēstures avots starpkaru perioda vēstures apguvē: Pētera Kundziña Latviešu zemnieku savienības 1925. gada priekšvēlēšanu plakāta "Stingra roka" piemērs

Agnese Geduševa

Latvijas PSR un Latvijas Republikas himnu mūzikas nozìme ar to saistito sabiedrisko norišu kontekstā

Viesturs Rasnacis

Vācijas loma Latvijas uzṇemšanā NATO (1990-2004)

13.00-14.00 Pusdienu pārtraukums

14.00-16.30 No plkst. 14.00 konferences darbs turpinās divās paralēlās darba grupās:

I - Latvijas vēsture no akmens laikmeta līdz 20. gadsimtam

Valmieras muzeja Izstāžu namā

II - Latvijas 20. gadsimta vēstures jautājumi

Valmieras muzeja Rūdolfa Vītola izstāžu zālē

16.30 Konferences slēgšana (Valmieras muzeja Izstāžu namā) Neformālā daḷa

\section{I darba grupa, 1. sēde}

14.00-15.30 Sēdi vada: Dr. hist. Viktorija Bebre (LU LVI), Dr. hist. Rūdolfs Brūzis (LU LVI)

14.00-14.20 Vanda Visocka

Keramikas trauku veidmasas sastāva tradicijas vēlā bronzas laikmeta pilskalnu materiālā Latvijas teritorijā

14.20-14.40 Liena Sakne

Kurzeme un Gotlande: noturīgu starpkultūru kontaktu raksturojums vēlajā dzelzs laikmetā 
14.40-15.00 Dardega Legzdina

Bioarheologija un stabilo izotopu analizes: lokālās izotopu ekolog̣ijas nozìme seno cilvēku uztura pētniecībā

$$
\text { Diskusija }
$$

15.30.-15.40 Pārtraukums

\section{I darba grupa, 2. sēde}

15.40-16.30 Sēdi vada: Dr. hist. Eva Eihmane, Dr. hist. Anita Čerpinska (LU LVI)

15.40-16.00 Edgars Plētiens

Kas bija un nebija pilsēta Livonijā: Raunas apdzìvotās vietas piemērs

16.00-16.20 Liga Irbe

Aizmirstie: Ernests Gideons fon Laudons un Toces pusmuiža. Cilvēka un vietas atgriešanās stāsts

$$
\text { Diskusija }
$$

16.30 Konferences slēgšana (Valmieras muzeja Izstāžu namā)

\section{II darba grupa, 1. sēde}

14.00-15.30 Sēdi vada: Dr. hist. Tālis Pumpuriṇš (ViA), Dr. hist. Jānis Šiliṇš (LNA)

14.00-14.20 Agnija Ruhocka

Latvijas Mākslas akadēmijas studentu organizācijas (1923-1940): to loma sabiedrībā un jauno mākslinieku profesionālajā izaugsmēe

14.20-14.40 Inna Gīle

Valmieras garnizona lazaretes darbỉba un nozime Latvijas Neatkarības kara laikā, 1919-1920

14.40.-15.00 Mārtiņš Dātavs

Latvijas dzīvnieku aizsardzības biedrības darbība (1935-1940)

$$
\text { Diskusija }
$$




\section{Il darba grupa, 2. sēde}

15.40-16.30 Sēdi vada: Dr. hist. Edvīns Evarts (LU LVI), Dr. hist. Ilgvars Butulis (LU VFF)

15.40.-16.00 Ginta Ieva Bikše

Latvijas un Spānijas attiecības (1936-1940) Spānijas pilsoṇu kara kontekstā

16.00-16.20 Kaspars Strods

Ebreji varakḷāniešu un apkārtnes iedzīvotāju kultūratmin̄ā: holokausts

\section{Diskusija}

16.30 Konferences slēgšana (Valmieras muzeja Izstāžu namā)

III konferences zinātniskā komisija:

Dr. hist. Viktorija Bebre (LU LVI)

Dr. hist. Ilze Boldāne-Zel̦enkova (LU LVI)

Dr. hist. Rūdolfs Brūzis (LU LVI)

prof. Dr. hist. Ilgvars Butulis (LU VFF)

Dr. hist. Anita Čerpinska (LU LVI)

Dr. hist. Edvīns Evarts (LU LVI)

Dr. hist. Eva Eihmane

prof. Dr. art. Jānis Kudiņš (JVLMA)

Dr. hist. Tālis Pumpuriņš (ViA)

Dr. hist. Jānis Šiliņš (LNA)

Konferenci organizē Valmieras muzeja vēsturnieks Alberts Rokpelnis (e-pasts: alberts.rokpelnis@valmiera.lv) un vadošā pētniece Liene Rokpelne, tālr. Nr. 64210874. 

Jauno vēsturnieku zinātniskie lasījumi III, 2018 The Scholarly Readings of Young Historians III, 2018

Izdevējs: LU Akadēmiskais apgāds

Aspazijas bulv. 5-132, Rīga, LV-1050

www.lu.lv/apgads 